\title{
Use of Environmental Tracers to Estimate Parameters for a Predevelopment Ground-Water-Flow Model of the Middle Rio Grande Basin, New Mexico
}

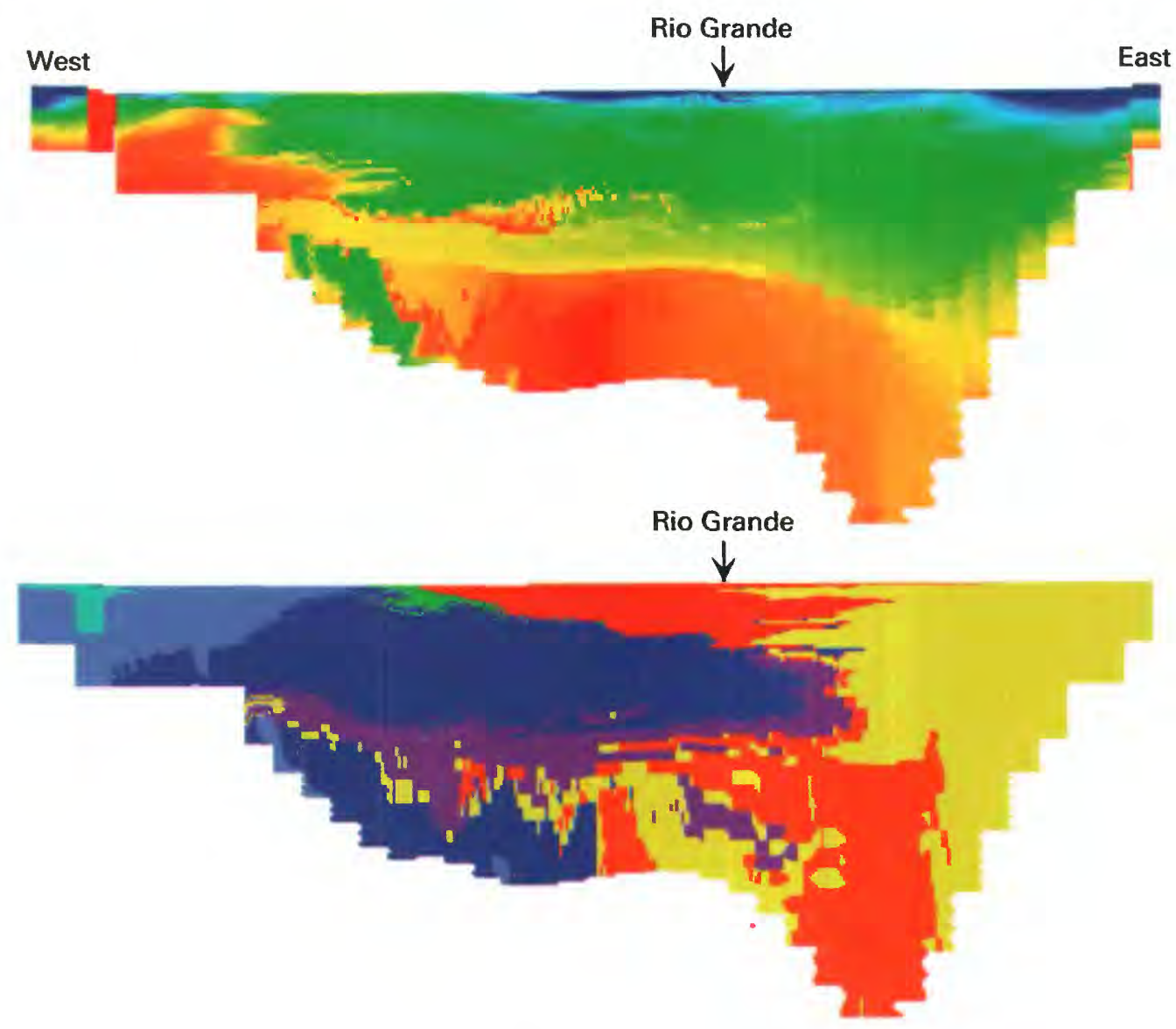

Water-Resources Investigations Report 03-4286 



\section{Use of Environmental Tracers to Estimate Parameters for a Predevelopment Ground-Water-Flow Model of the Middle Rio Grande Basin, New Mexico}

Ward E. Sanford, L. Niel Plummer, Douglas P. McAda, Laura M. Bexfield, and Scott K. Anderholm

Water-Resources Investigations Report 03-4286 


\section{U.S. Department of the Interior \\ Gale A. Norton, Secretary}

U.S. Geological Survey

Charles G. Groat, Director

U.S. Geological Survey, Reston, Virginia: 2004

For sale by U.S. Geological Survey, Information Services

Box 25286, Denver Federal Center

Denver, CO 80225

For more information about the USGS and its products:

Telephone: 1-888-ASK-USGS

World Wide Web: http://www.usgs.gov/ 


\section{CONTENTS}

CONVERSIONS FACTORS AND DATUM …………................................................................ vi

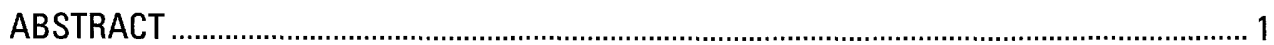

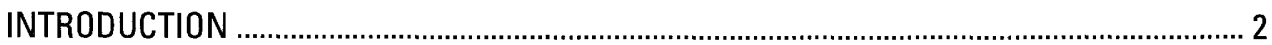

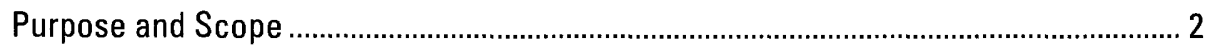

Description of the Study Area .................................................................................... 5

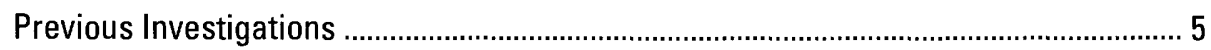

HYDROGEOLOGY AND HYDROCHEMISTRY OF THE MIDDLE RIO GRANDE BASIN ................5

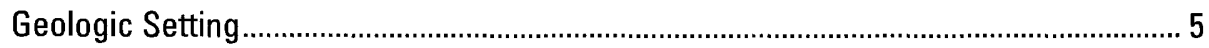

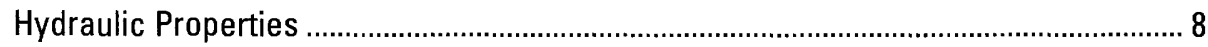

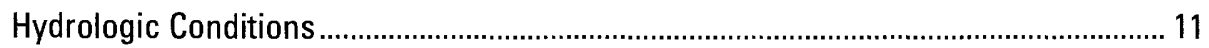

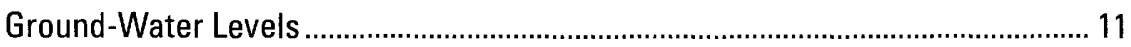

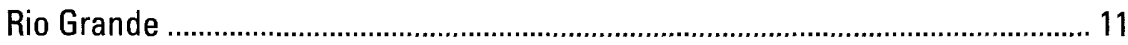

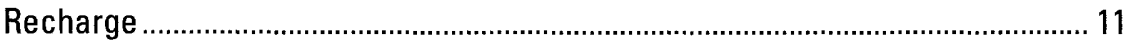

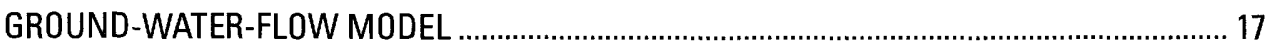

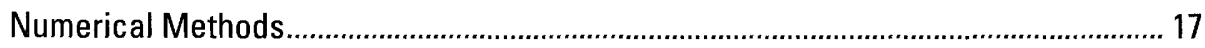

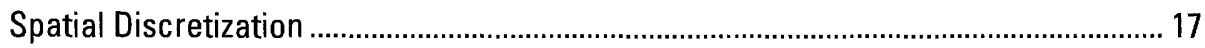

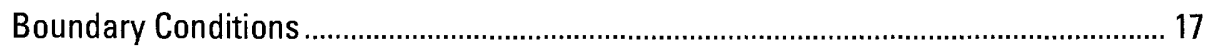

Head-Dependent River Boundary Conditions ....................................................... 17

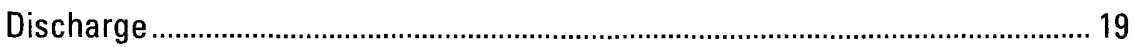

Geochemical Conditions................................................................................................ 19

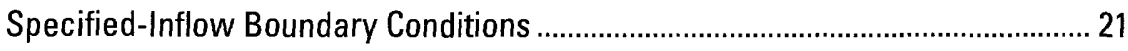

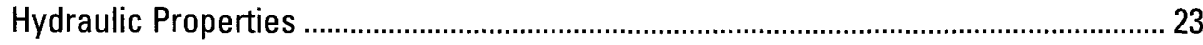

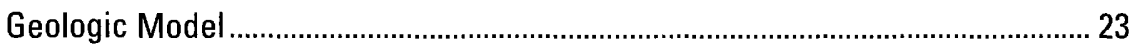

Hydraulic Conductivity Zones ............................................................................... 28

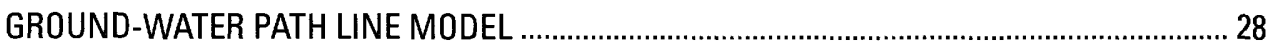

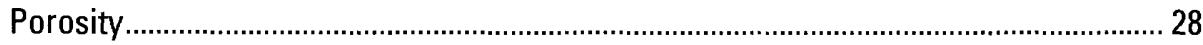

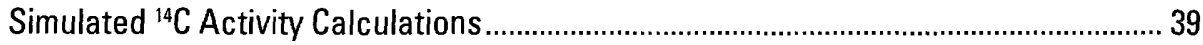

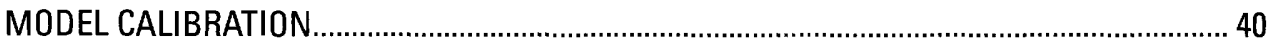

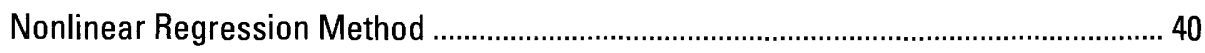

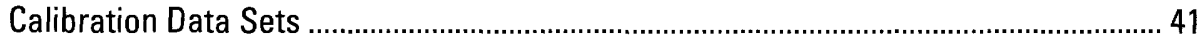

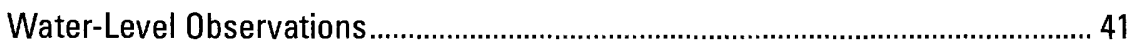

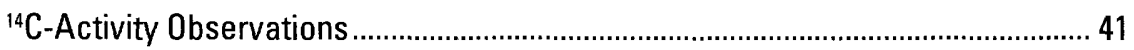

Hydrochemical-Zone Observations ....................................................................... 45

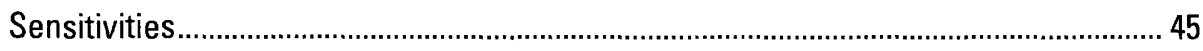

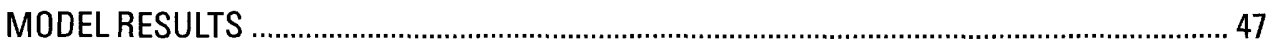

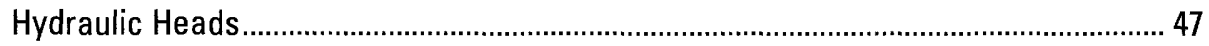

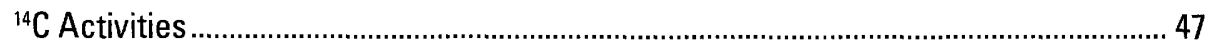

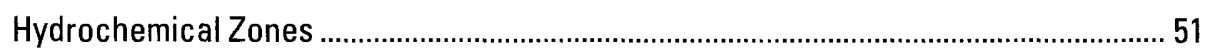

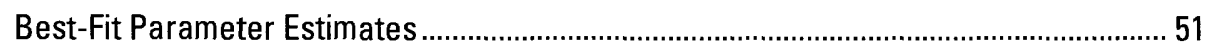

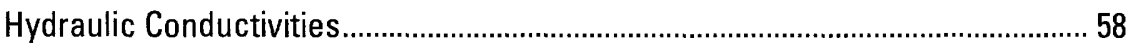

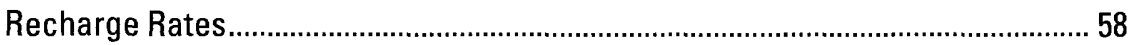

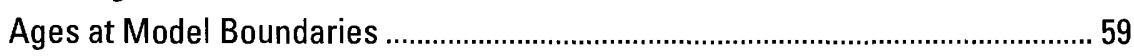

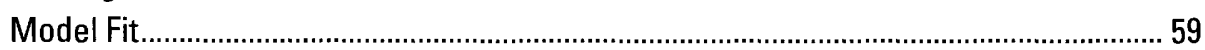

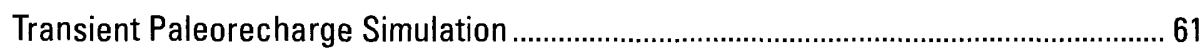

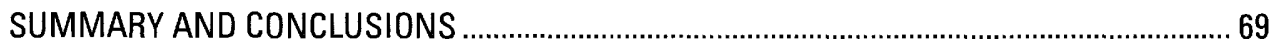

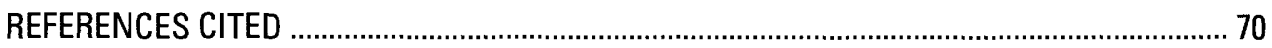

APPENDIX A. Information and Observations for Individual Wells ........................................ 75

APPENDIX B. Computer Programs ..................................................................................... 93 


\section{FIGURES}

1-11. Maps showing:

1. Location of the Middle Rio Grande Basin in central New Mexico (modified from Thorn and others, 1993, fig. 1).

2. Physiographic features in the vicinity of the Middle Rio Grande Basin............................. 4

3. Major geologic and tectonic features in the vicinity of the Middle Rio Grande Basin (modified from Kelley, 1977; Thorn and others, 1993, fig. 4; Kernodle, 1998, fig. 14).......... 7

4. Water table in its predevelopment configuration (modified from Bexfield and Anderholm, 2000).

5. Mountain-front recharge, tributary recharge (solid lines), and underflow estimates (dashed lines), in acre-feet per year, used by Kernodle and others (1995) and Tiedeman and others (1998), and estimates used by McAda and Barroll (2002) (italics) that include those of Anderholm (2001)

6. Specific conductance in ground water of the Middle Rio Grande Basin (from Plummer and others, 2004).

7. Contours of deuterium composition, $\partial^{2} \mathrm{H}$, for ground water of the Middle Rio Grande Basin (from Plummer and others, 2004)

8. Contours of conventional radiocarbon age of DIC (dissolved inorganic carbon) in ground water of the Middle Rio Grande Basin (from Plummer and others, 2004).

9. Hydrochemical zones in the Middle Rio Grande Basin (from Plummer and others, 2004). 16

10. Plan view of finite-difference grid for the ground-water-flow model.............................. 19

11. Altitude, in feet above sea level, of the base of model layer 1 ........................................ 20

12. Diagram showing the configuration of model layers.

13-26. Maps showing:

13. Location of head-dependent river cells in the ground-water-flow model.

14. Location of mountain-front and arroyo recharge cells in the ground-water-flow model.

15. Location of specified underflow cells in the ground-water-flow model

16. Simplified structure of the Albuquerque Basin, showing subbasins identified from gravity data in Grauch and others (2001).

17. Altitude of the base of the ground-water-flow model. Surface is based on geophysical data in Cole and others (2001) and Grauch and others (2001).

18. Hydraulic conductivity zones of layer 1 as defined in (A) the geologic model of Cole (2000b), and (B) the ground-water-flow model

19. Hydraulic conductivity zones of layer 2 as defined in $(A)$ the geologic model of Cole $(2000 \mathrm{~b})$, and $(B)$ the ground-water-flow model

20. Hydraulic conductivity zones of layer 3 as defined in $(A)$ the geologic model of Cole $(2000 \mathrm{~b})$, and (B) the ground-water-flow model

21. Hydraulic conductivity zones of layer 4 as defined in (A) the geologic model of Cole $(2000 \mathrm{~b})$, and $(B)$ the ground-water-flow model

22. Hydraulic conductivity zones of layer 5 as defined in $(A)$ the geologic model of Cole $(2000 \mathrm{~b})$, and $(\mathrm{B})$ the ground-water-flow model

23. Hydraulic conductivity zones of layer 6 as defined in $(A)$ the geologic model of Cole (2000b), and (B) the ground-water-flow model

24. Hydraulic conductivity zones of layer 7 as defined in $(A)$ the geologic model of Cole $(2000 \mathrm{~b})$, and $(B)$ the ground-water-flow model

25. Hydraulic conductivity zones of layer 8 as defined in $(A)$ the geologic model of Cole (2000b), and (B) the ground-water-flow model 
26. Hydraulic conductivity zones of layer 9 as defined in (A) the geologic model of Cole $(2000 \mathrm{~b})$, and $(\mathrm{B})$ the ground-water-flow model.

27. Diagram showing cross-sectional views of the hydraulic conductivity zones along rows (A) 22, (B) 60, and (C) 90 of the ground-water-flow model. See figure 18 for locations of section lines.

28-30. Maps showing:

28. Location of hydraulic-head observations used to calibrate the predevelopment ground-water-flow model.

29. Location of carbon-14 samples used to calibrate the predevelopment ground-water-flow model.

30. Location of geochemical-target regions used to calibrate the ground-water flow model.

31-32. Graphs showing:

31. Composite-scaled sensitivities for parameters of hydraulic conductivity, anisotropy, and riverbed conductance at the optimized or specified values (see table 3 for parameter descriptions, locations, and values).

32. Composite-scaled sensitivities for parameters of recharge, porosity, and initial underflow age at the optimized or specified values (see table 3 for parameter descriptions, locations, and values)

33-38. Maps showing:

33. Simulated water levels in layer 2 of the steady-state ground-water-flow model............. 48

34. Simulated water levels in layer 6 of the steady-state ground-water-flow model............ 49

35. Simulated predevelpment water levels, in feet above sea level, in the vicinity of Albuquerque in layer 2 of the ground-water-flow model ................................................ 50

36. Simulated ground-water ages in layers 2 and 6 of the steady-state ground-water-flow model..

37. Simulated (A) ground-water ages and (B) source of water along row 75 of the steady-state ground-water-flow model (see fig. 36 for location of row 75).

38. Simulated geochemical zones in layers 2 and 6 of the steady-state

ground-water-flow model.

39-45. Graphs showing:

39. Optimized parameter values and 95 percent linear confidence intervals for hydraulic conductivity and riverbed conductance (see table 3 for parameter descriptions).

40. Optimized parameter values and 95 percent linear confidence intervals for anisotropy (see table 3 for parameter descriptions)

41. Optimized parameter values and 95 percent linear confidence intervals for recharge and initial underflow ages (see table 3 for parameter descriptions).

42. Observed water levels plotted against simulated water levels. Datum equals 4,650 feet above sea level

43. Weighted simulated values of water levels plotted against weighted residuals..................60

44. Observed plotted against simulated percent modern carbon...............................................63

45. Weighted simulated values of percent modern carbon plotted against weighted residuals.

46-49. Maps showing:

46. Spatial distribution of residuals between the observed and simulated water levels. .... 64

47. Spatial distribution of weighted residuals between the observed and simulated water levels. 
48. Spatial distribution of residuals between the observed and simulated ${ }^{14} \mathrm{C}$ activities ..... 66

49. Spatial distribution of weighted residuals between the observed and simulated ${ }^{14} \mathrm{C}$ activities

50. Graph showing optimized values of paleorecharge multipliers and their 95 percent linear confidence intervals.

\section{TABLES}

1. Median values of selected water-quality parameters by hydrochemical zone (from Plummer and others, 2004).

2. Information on geochemical-target regions (fig. 30) defined for use in calibration against the geochemical zones.

3. Parameters of the ground-water-flow model and their optimized values.

4. Estimates of inflow and outflow from the Middle Rio Grande Basin from recent studies.

A1. Information on wells from which water levels were used in the calibration of the ground-water-flow model.

A2. Information on wells from which ${ }^{14} \mathrm{C}$ activities were used in the ground-water-flow model calibration

A3. Observed and simulated values of water levels (italics), ${ }^{14} \mathrm{C}$ activities, and hydrochemical zones (bold)

\section{CONVERSIONS FACTORS AND DATUM}

\begin{tabular}{|c|c|c|}
\hline Multiply & By & To obtain \\
\hline \multicolumn{3}{|c|}{ Length } \\
\hline inch (in.) & 2.54 & centimeter $(\mathrm{cm})$ \\
\hline foot $(\mathrm{ft})$ & 0.3048 & meter $(\mathrm{m})$ \\
\hline mile (mi) & 1.609 & kilometer $(\mathrm{km})$ \\
\hline \multicolumn{3}{|c|}{ Area } \\
\hline acre & 4,047 & square meter $\left(\mathrm{m}^{2}\right)$ \\
\hline acre & 0.004047 & square kilometer $\left(\mathrm{km}^{2}\right)$ \\
\hline square foot $\left(\mathrm{ft}^{2}\right)$ & 0.09290 & square meter $\left(\mathrm{m}^{2}\right)$ \\
\hline square mile $\left(\mathrm{mi}^{2}\right)$ & 2.590 & square kilometer $\left(\mathrm{km}^{2}\right)$ \\
\hline \multicolumn{3}{|c|}{ Volume } \\
\hline gallon (gal) & 3.785 & liter (L) \\
\hline cubic foot $\left(\mathrm{ft}^{3}\right)$ & 0.02832 & cubic meter $\left(\mathrm{m}^{3}\right)$ \\
\hline acre-foot (acre-ft) & 1,233 & cubic meter $\left(\mathrm{m}^{3}\right)$ \\
\hline \multicolumn{3}{|c|}{ Flow rate } \\
\hline acre-foot per year (acre-ft/yr) & 1,233 & cubic meter per year $\left(\mathrm{m}^{3} / \mathrm{yr}\right)$ \\
\hline cubic foot per second $\left(\mathrm{ft}^{3} / \mathrm{s}\right)$ & 0.02832 & cubic meter per second $\left(\mathrm{m}^{3} / \mathrm{s}\right)$ \\
\hline gallon per day (gal/d) & 0.003785 & cubic meter per day $\left(\mathrm{m}^{3} / \mathrm{d}\right)$ \\
\hline \multicolumn{3}{|c|}{ Mass } \\
\hline ounce, avoirdupois $(\mathrm{oz})$ & 28.35 & $\operatorname{gram}(\mathrm{g})$ \\
\hline pound, avoirdupois (lb) & 0.4536 & kilogram (kg) \\
\hline \multicolumn{3}{|c|}{ Hydraulic conductivity } \\
\hline foot per day $(\mathrm{ft} / \mathrm{d})$ & 0.3048 & meter per day $(\mathrm{m} / \mathrm{d})$ \\
\hline
\end{tabular}

Temperature in degrees Celsius $\left({ }^{\circ} \mathrm{C}\right)$ may be converted to degrees Fahrenheit $\left({ }^{\circ} \mathrm{F}\right)$ as follows:

$$
{ }^{\circ} \mathrm{F}=\left(1.8 \times^{\circ} \mathrm{C}\right)+32
$$

Temperature in degrees Fahrenheit $\left({ }^{\circ} \mathrm{F}\right)$ may be converted to degrees Celsius $\left({ }^{\circ} \mathrm{C}\right)$ as follows:

$$
{ }^{\circ} \mathrm{C}=\left({ }^{\circ} \mathrm{F}-32\right) / 1.8
$$




\title{
Use of Environmental Tracers to Estimate Parameters for a Predevelopment Ground-Water-Flow Model of the Middle Rio Grande Basin, New Mexico
}

\author{
Ward E. Sanford, L. Niel Plummer, Douglas P. McAda, Laura M. Bexfield, and Scott K. Anderholm
}

\section{ABSTRACT}

The question of the availability of ground water as a long-term resource in the Middle Rio Grande Basin of central New Mexico has been addressed recently by the development of ground-water-flow models by the U.S. Geological Survey. An initial model constructed in 1994 was updated by Kernodle and others (1995), and then calibrated by Tiedeman and others (1998) using nonlinear regression methods and additional hydrologic observations. A new model was constructed using some of the results from the Middle Rio Grande Basin initiative by McAda and Barroll (2002). This report documents the use of ${ }^{14} \mathrm{C}$ activities and the location of hydrochemical zones to constrain parameter values used in a predevelopment ground-water-flow model of the Middle Rio Grande Basin. The universal inverse modeling code, UCODE, was used to help estimate hydraulic conductivities of hydrogeologic units and current and past recharge along the basin margins and tributary rivers. The water levels in the basin were simulated using MODFLOW, and travel times to wells and source-area delineation were simulated using MODPATH.

A three-dimensional geologic model was discretized into a three-dimensional MODFLOW grid of the basin. Major hydrogeologic units in the geologic model included volcanic rocks, and several units that represent the Santa Fe Group sediments, including ancestral gravels from the Rio Grande and some finer grained units that represent the middle and lower Santa Fe Group. The MODFLOW grid represented the hydrogeologic units with nine layers of variable thickness totaling up to 12,000 feet in places, and a uniform horizontal grid resolution of one square kilometer ( 0.386 square miles). The bottom of the model was considered to be the base of the poorly to semiconsolidated basin-fill sediments as defined by geophysical observations. Observations that were used to calibrate a steady-state predevelopment model, and then a transient paleohydrologic model, included 200 water levels and $200{ }^{14} \mathrm{C}$ activities. Observed water levels were compared with simulated water levels, and observed ${ }^{14} \mathrm{C}$ activities were compared with simulated ${ }^{14} \mathrm{C}$ activities based on travel times to individual wells. In addition, the distributions of ground water that originated from the Rio Grande and Rio Puerco were also used as constraints by comparing the percentage of river water in certain hydrochemical target regions with the percentage is simulated river water. The ${ }^{14} \mathrm{C}$ activities were adjusted for chemical reactions along the flow paths and for long-term variation in atmospheric input.

Hydraulic conductivities estimated for the model using the inverse procedure were similar to values that had been estimated in the previous models. The best-fit value of hydraulic conductivity of the Rio Grande alluvium and the volcanic rocks averaged about 30 feet per day, which is in agreement with field tests and earlier models. The best-fit hydraulic conductivity of a silty layer identified in the geologic model was estimated to be about 0.4 feet per day, which is also in agreement with field tests. The ratio of horizontal to vertical hydraulic conductivity was estimated for 12 different regions of the basin, with the best-fit ratios for the different regions ranging from 230:1 to 3,400:1.

Basin-margin and tributary recharge estimates were lower than estimates used in previous models. The 1995 ground-water-flow model assigned total margin and tributary recharge values of 138,600 acre-feet per year, based primarily on previous estimates using the water-budget method. The 1998 version of the model estimated this external recharge to be 95,500 acre-feet per year, based on inverse modeling using primarily water levels. The 2002 version of the model used a combination of estimates from previous sources and those from a chloride mass-balance study to arrive at a recharge of 67,500 acre-feet per year. The present study estimates recharge at 35,700 acre-feet per year, based on inverse modeling that includes 200 ground-water ages and the distribution of river waters within the basin.

The water-budget methods used to estimate recharge in the earlier models do not account for runoff that enters the 
Rio Grande, or evapotranspiration of runoff once it enters the subsurface. In addition, recharge estimates for the mountain fronts on the eastern side of the basin have been made independently using the chloride mass-balance method. Estimates by the chloride method were used in the 1998 model and are close to the estimates made in the present study. The lower recharge estimates from the current model are also consistent with the simulated water levels and source-area delineation. A ground-water trough is simulated west of the Rio Grande that is partially occupied by ground water that is derived from the Rio Grande. A ground-water trough and the Rio Grandederived ground water have been observed using water levels and hydrochemistry, respectively. The 1995 model with the greatest recharge did not reproduce these features, and the 1998 and 2002 models used hydraulic conductivity zones or barriers to produce the trough.

In addition to the steady-state predevelopment model, a transient paleohydrologic model was calibrated to determine if the ${ }^{14} \mathrm{C}$ activities could indicate whether recharge rates had changed during the past 30,000 years. Paleolimnological evidence from central New Mexico has indicated that the climate in the region was wetter during the last glacial maximum ( 20,000 to 25,000 years ago). The paleohydrologic simulation involved a period of 30,000 years, with an separate value of recharge estimated every 2,500 years. These paleorecharge values were estimated simultaneously with the parameters from the original steady-state model. The transient, paleohydrologic simulation suggests that recharge to the basin during the last glacial maximum was 7 to 15 times greater than that at present, and after the end of the Ice Age was as little as half that at present. However, substantial uncertainties are associated with these paleorecharge estimates.

\section{INTRODUCTION}

In the Middle Rio Grande Basin (MRGB) of central New Mexico (fig. 1), ground water is a primary water source for all municipal, industrial, and domestic uses except agricultural irrigation. Ground-water withdrawals around the city of Albuquerque steadily increased from the 1940s through the 1990s, resulting in large declines in water levels. Since the beginning of the last century (Lee, 1907; Bryan, 1938), regulatory, scientific, and academic institutions have been studying the hydrogeology of the basin. Since the 1980s, numerical models of ground-water flow within the basin have been constructed. The goals of these hydrogeologic and modeling studies have been to characterize the basin geology and the ground-waterflow system and to provide this information to water-resources managers involved with the basin.

In the early $1990 \mathrm{~s}$, in cooperation with the City of Albuquerque, the New Mexico Bureau of Mines and Mineral Resources synthesized the hydrogeologic framework of the MRGB (Hawley and Haase, 1992), and the U.S. Geological Survey (USGS) synthesized the knowledge of the basin geohydrology (Thorn and others, 1993). Following this, the USGS developed a numerical ground-water-flow model of the basin on the basis of this geologic and hydrologic understanding (Kernodle and others, 1995). To realistically represent basin features and the hydrologic record, the spatial and temporal discretization used in the model was relatively fine. Consequently, obtaining the model solution, which is the spatial and temporal distribution of hydraulic heads and flows within the basin, was computationally intensive and required a large number of hours with the computers available at the time. Because of this large computational requirement, the model was not rigorously calibrated. Instead, reasonable values of model parameters were assumed, using field estimates and knowledge of and inferences about geologic and hydrologic conditions in the basin.

Between 1995 and 2002 the U.S. Geological Survey undertook a multi-year MRGB initiative to improve the understanding of the water resources in and around the MRGB (Bartolino and Cole, 2002). The MRGB study included geologic and fault mapping, geophysical investigations of the subsurface, and generation of high-resolution cartographic data to aid geologic mapping and land-surface analysis within the basin. Hydrologic studies included several investigations of recharge along mountain fronts and tributaries to the Rio Grande (Nimmo, 1997; Constantz, 1998; Stonestrom and Atkins, 1998; Anderholm, 2001), field studies of the interaction of ground water and surface water in the basin (Bartolino and Niswonger, 1999), collection and interpretation of ground-water chemistry and age data (Plummer and others, 2004), a modeling study using nonlinear regression methods for calibration (Tiedeman and others, 1998), and a model that included much of the new information that was gathered during the MRGB study (McAda and Barroll, 2002). The work described in this report was also funded as part of the MRGB study, and involves using the ground-water chemistry and age data and inverse modeling to further improve estimates of the recharge and hydraulic conductivity parameters that have been used in the ground-water-flow models of the MRGB.

\section{Purpose and Scope}

The purpose of this report is to document the use of environmental tracers to estimate parameters being used in ground-water-flow models of the MRGB. To estimate these parameters a predevelopment model was calibrated using the environmental tracers. A transient model that included pumping was not constructed because the primary focus was on using naturally occurring long-term tracers, and accounting for the effects of recent manmade stresses was secondary. The primary focus of this work was to improve estimates of model parameters, including recharge values, that can be constrained by ground-water ages and other hydrochemical observations. Several steps were involved in accomplishing this goal. Collection and analysis of the ground-water chemistry and age data were done first, and have been reported by Plummer and others (2004). The finite-difference grids representing the model that were developed by Kernodle and others (1995) and by Tiedeman and others (1998) were modified to give a 


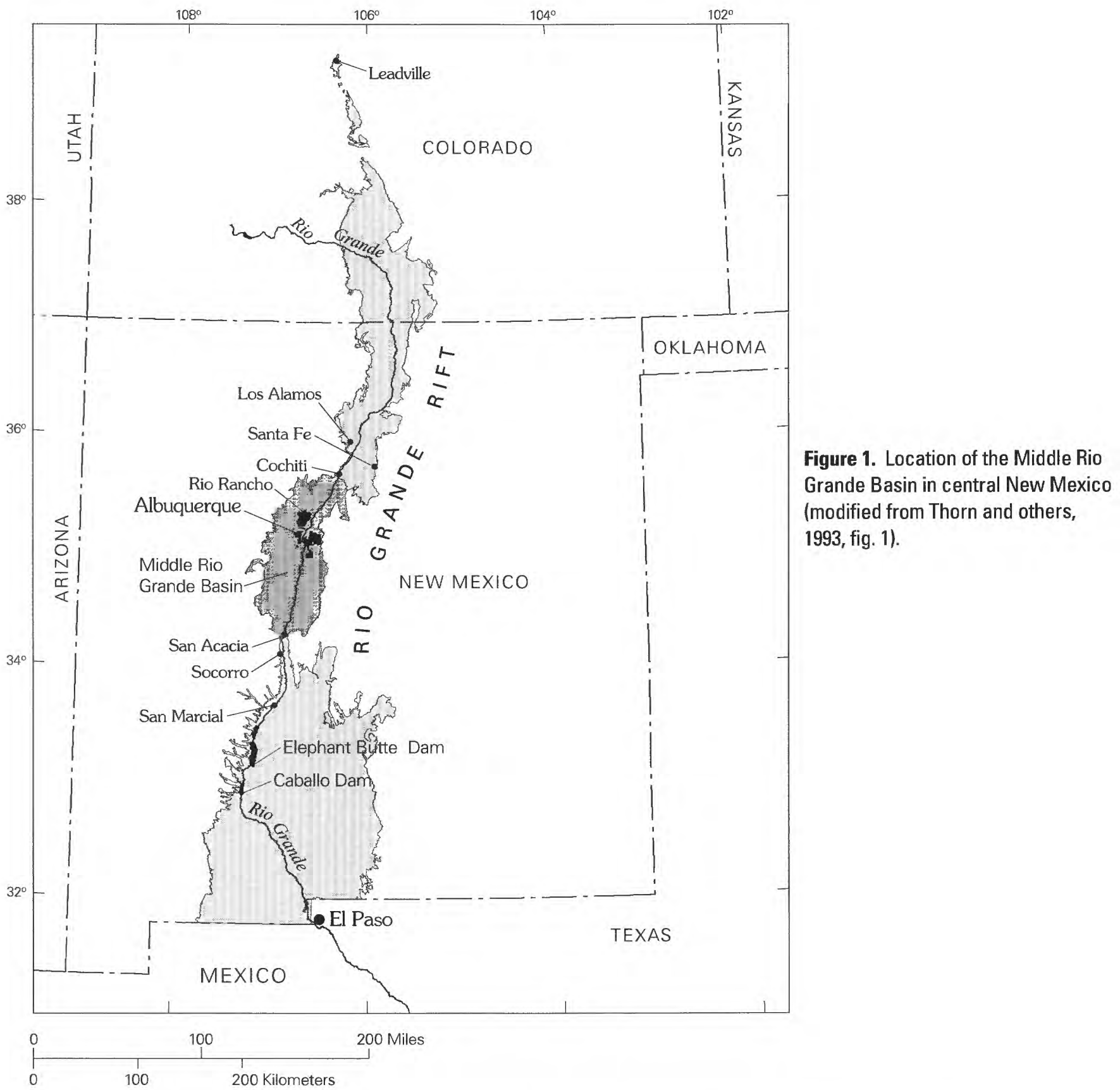

more even resolution over the entire basin, and to extend the lower layers of the model to the base of the unconsolidated Cenozoic sediments. The three-dimensional geologic model of Cole (2001b) was used to define hydraulic conductivity zones within the three-dimensional ground-water-flow model.

The calibration was performed first assuming steady-state predevelopment hydrologic conditions. Second, a paleohydrologic simulation was calibrated to estimate paleorecharge rates based on the distribution of ${ }^{14} \mathrm{C}$ ages. Water-level data were chosen that best represented predevelopment conditions. This data set was reduced to a set of 200 water-level observations that were used to calibrate the flow model. Ground-water ages based on ${ }^{14} \mathrm{C}$ activities were also compiled into a data set of 200 observations. Finally, hydrochemical zones mapped by Plummer and others (2004) were used to constrain sourcearea delineation of the ground water within selected areas of the basin. These three sets of observations were used to make best estimates for the values of hydraulic conductivity and recharge. The estimates were made by calibrating the model with an inverse modeling code that uses nonlinear regression to minimize the residuals in an objective function that includes, in this case, the three types of observations. The inverse modeling was also used to estimate paleorecharge rates over the past 30,000 years. Nonlinear methods were used initially to minimize the model error for the steady-state and transient recharge models. Final minimization of the error was obtained by additional manual adjustment of the individual model parameters. 


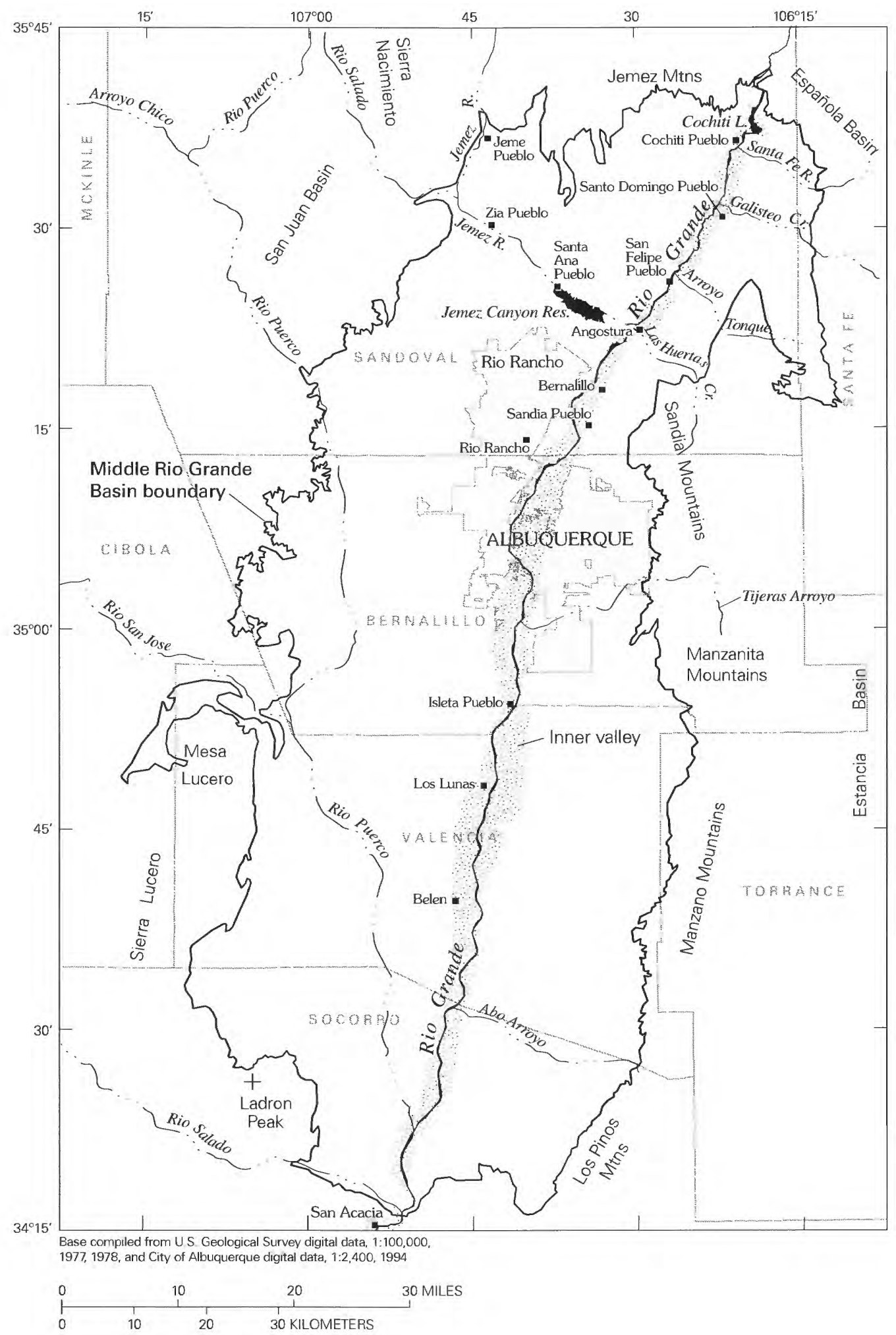

Figure 2. Physiographic features in the vicinity of the Middle Rio Grande Basin. 


\section{Description of the Study Area}

The MRGB (also known as the Albuquerque Basin) occupies about 3,000 square miles in central New Mexico (fig. 1). The basin is one in a series of north-trending structural basins within the Rio Grande Rift, a region of Cenozoic crustal extension reaching from central Colorado into northern Mexico. The Rio Grande enters the basin from the northeast near Cochiti Pueblo, and exits the basin through a basin-fill constriction near San Acacia in the south (fig. 2). Major tributaries to the Rio Grande include the Santa Fe River, the Jemez River, and the Rio Puerco. Major arroyos entering the Rio Grande include Tijeras and Abo Arroyos. Land-surface altitudes of the basin-fill deposits range from about 4,800 feet above sea level at the southern end of the basin to about 6,000 feet above sea level at the northern end near the Jemez Mountains.

The climate is semiarid, with long-term average precipitation ranging from about 8 inches per year near the Rio Grande to about 23 inches per year at the crest of the Sandia Mountains (Thorn and others, 1993, table 1), which form part of the eastern boundary of the basin. Mean annual temperatures range from about $56^{\circ} \mathrm{F}$ in the lower elevations to about $38^{\circ} \mathrm{F}$ near the crest of the Sandia Mountains. Mean annual potential evapotranspiration ranges from less than 50 inches in the mountains to more than 60 inches near the Rio Grande (Thorn and others, 1993, fig. 10). Vegetation in the region consists predominantly of evergreen trees in the mountains, rangeland grasses and shrubs in the basin, and phreatophytes and irrigated crops in the inner valley of the Rio Grande. The metropolitan area associated with the city of Albuquerque lies in the north-central part of the basin and has been growing rapidly since the mid-20тн century, with a population of greater than 700,000 in 2000 .

\section{Previous Investigations}

Investigations of geologic and hydrologic conditions in the MRGB began in the early $20 \mathrm{TH}$ century, but began to increase in frequency during the 1960 s. Thorn and others (1993) and McAda (1996) provide fairly comprehensive summaries of these investigations. The geology and hydrology of the MRGB were recently described by Hawley and Haase (1992), Thorn and others (1993), and Hawley and others (1995). Several three-dimensional numerical models of ground-water flow in the basin have been developed. Kernodle and Scott (1986) constructed a model of steady-state groundwater flow, and Kernodle and others (1987) expanded this model to simulate transient conditions. Later, Kernodle and others (1995) constructed a new transient model of groundwater flow in the basin. Compared with earlier flow models, this model incorporated more recent interpretations of the subsurface and more realistically represented the interaction of the ground-water- and surface-water-flow system in the inner valley. The model by Kernodle and others (1995) was never calibrated rigorously because of the fine grid and computational requirements at the time. Kernodle (1998) presented revisions to the 1995 model in which the representation of some hydrogeologic conditions was updated.

Tiedeman and others (1998) constructed another model using a coarser grid that could be calibrated using nonlinear regression methods. That study used primarily transient waterlevel data from across the basin as observations with which to fit the simulations using the USGS code MODFLOWP (Hill, 1992). One major purpose of the study was to determine the potential cause of a water-table trough in the west-central part of the basin discovered originally by Meeks (1949), Bjorklund and Maxwell (1961), and Titus (1963). Six different subsurface configurations were simulated by Tiedeman and others (1998) to reproduce the trough assuming either the presence of (1) a high hydraulic conductivity zone, (2) a low-permeability north-south trending fault, or (3) a greater total sediment thickness for the basin. Results indicated that the first two configurations resulted in a significantly better fit to the data, but no field evidence has yet been produced to conclusively support the existence of any of these configurations.

McAda and Barroll (2002) incorporated the geologic information from Cole (2001b) to construct an improved version of the model of Kernodle and others (1995). They also incorporated recent estimates of recharge from the eastern mountain front from Anderholm (2001), and some of the results from this study and the recent ground-water chemistry and age study by Plummer and others (2004).

Many investigations have been conducted in association with the MRGB study (Bartolino and Cole, 2002). Geophysical studies of the basin by the USGS have included electromagnetic surveys (Deszcz-Pan and others, 1999), and aeromagnetic and gravity surveys (Grauch, 2000). Geologic studies have included the mapping of faults (Minor and Shock, 1998) and stratigraphy (Stone and Allen, 1998), and the construction of a three-dimensional geologic model of the basin (Cole, 2001b). Field-based estimates of recharge have been conducted for the Rio Grande (Bartolino and Niswonger, 1999), the eastern mountain front (Anderholm, 2001), and several prominent arroyos (Constantz, 1998; Stonestrom and Atkins, 1998; Thompson and others, 1999; Stewart and Constantz, 2000). Geochemical studies have focused on sampling the ground water and surface water to analyze for major chemical constituents and environmental tracers such as stable isotopes and radiocarbon (Plummer and others, 2004). The parameter estimates described in this report are based on a model that incorporates data from the recent geologic and hydrochemical studies.

\section{HYDROGEOLOGY AND HYDROCHEMISTRY OF THE MIDDLE RIO GRANDE BASIN}

\section{Geologic Setting}

The MRGB is one of several structural basins that are part of the Rio Grande Rift, a region formed by Cenozoic extension that stretches from Colorado through the length of central New Mexico into northern Mexico (figs. 1, 3). The main period of extension occurred from about 30 million years ago (Ma) to 


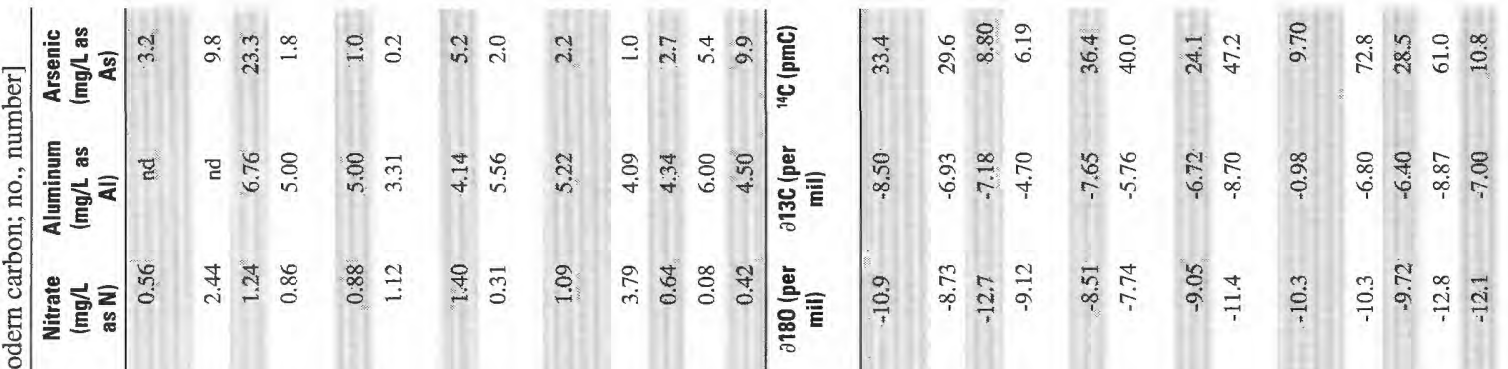

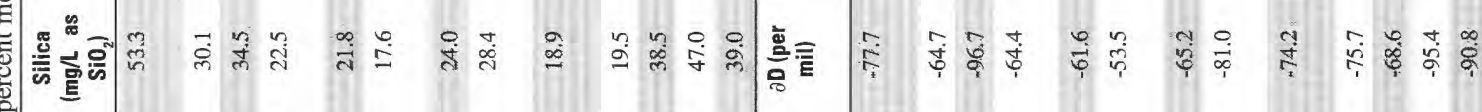

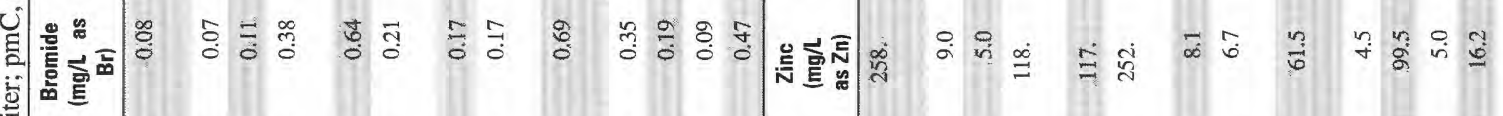

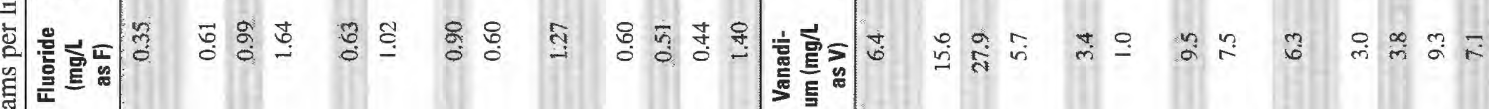

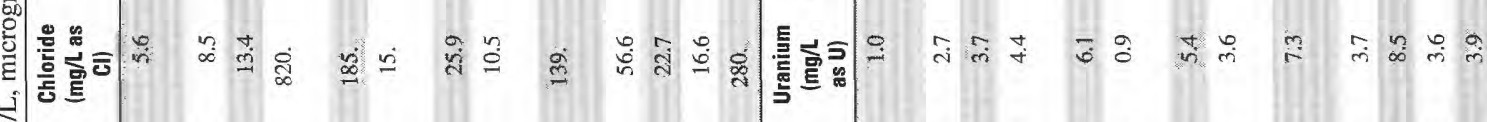

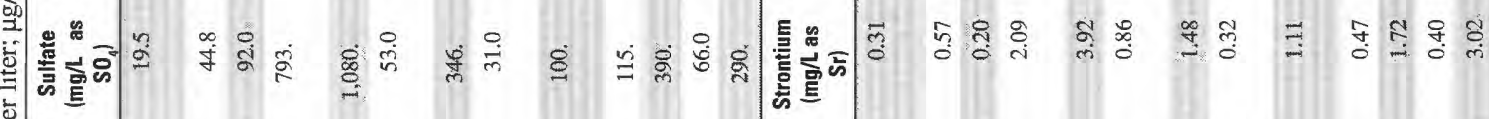

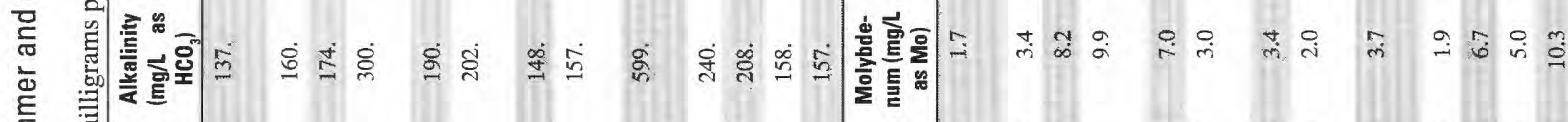

至

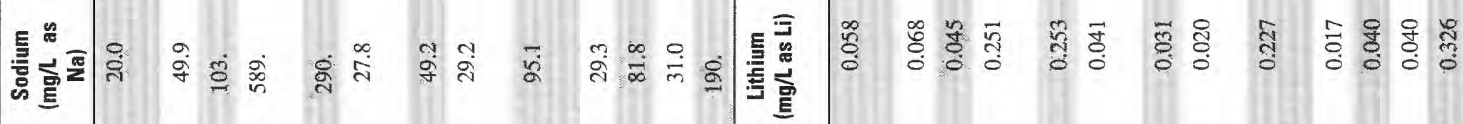

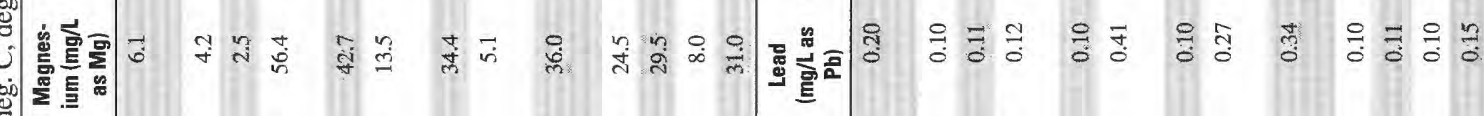
党

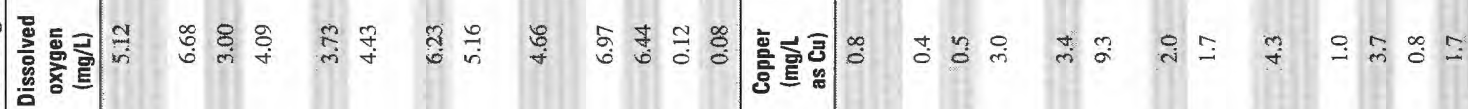

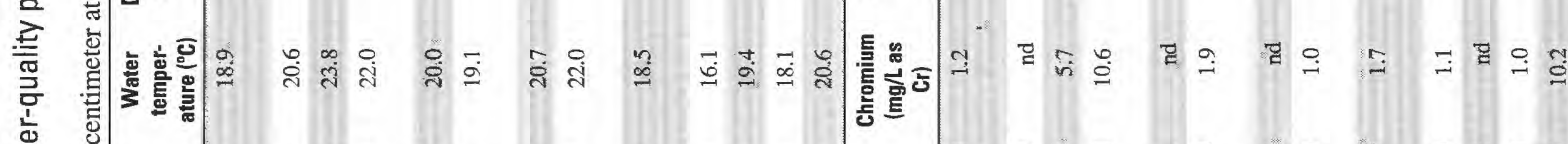

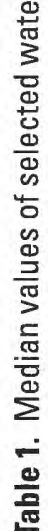

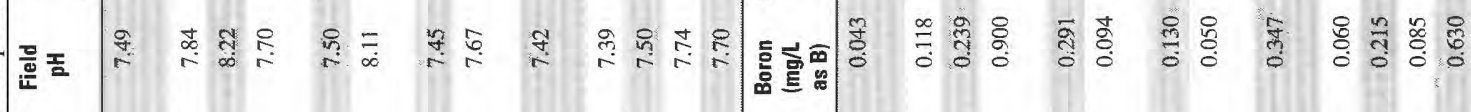

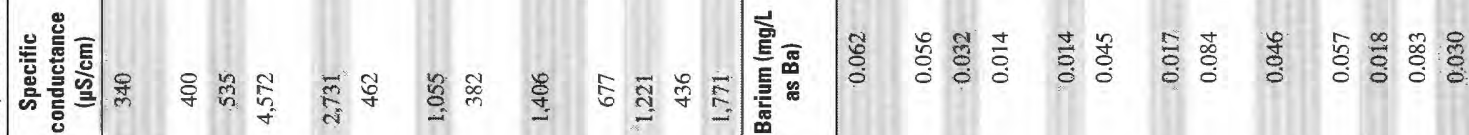

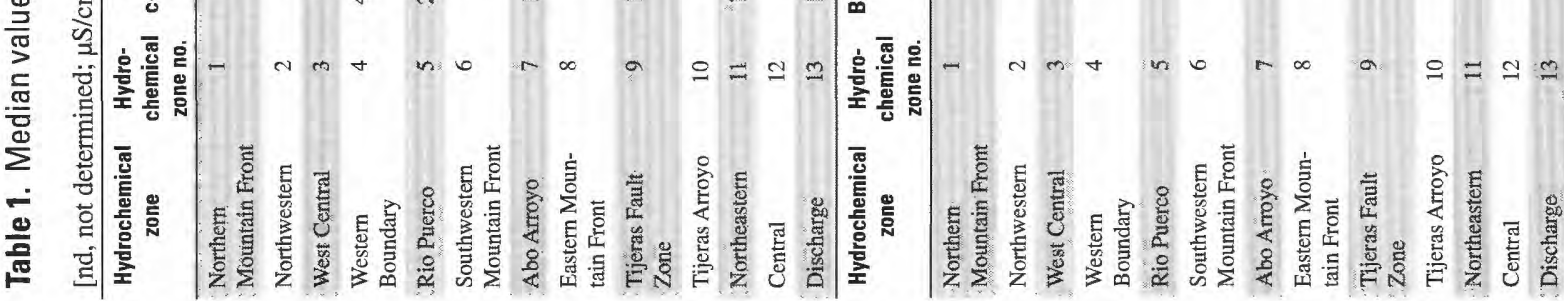




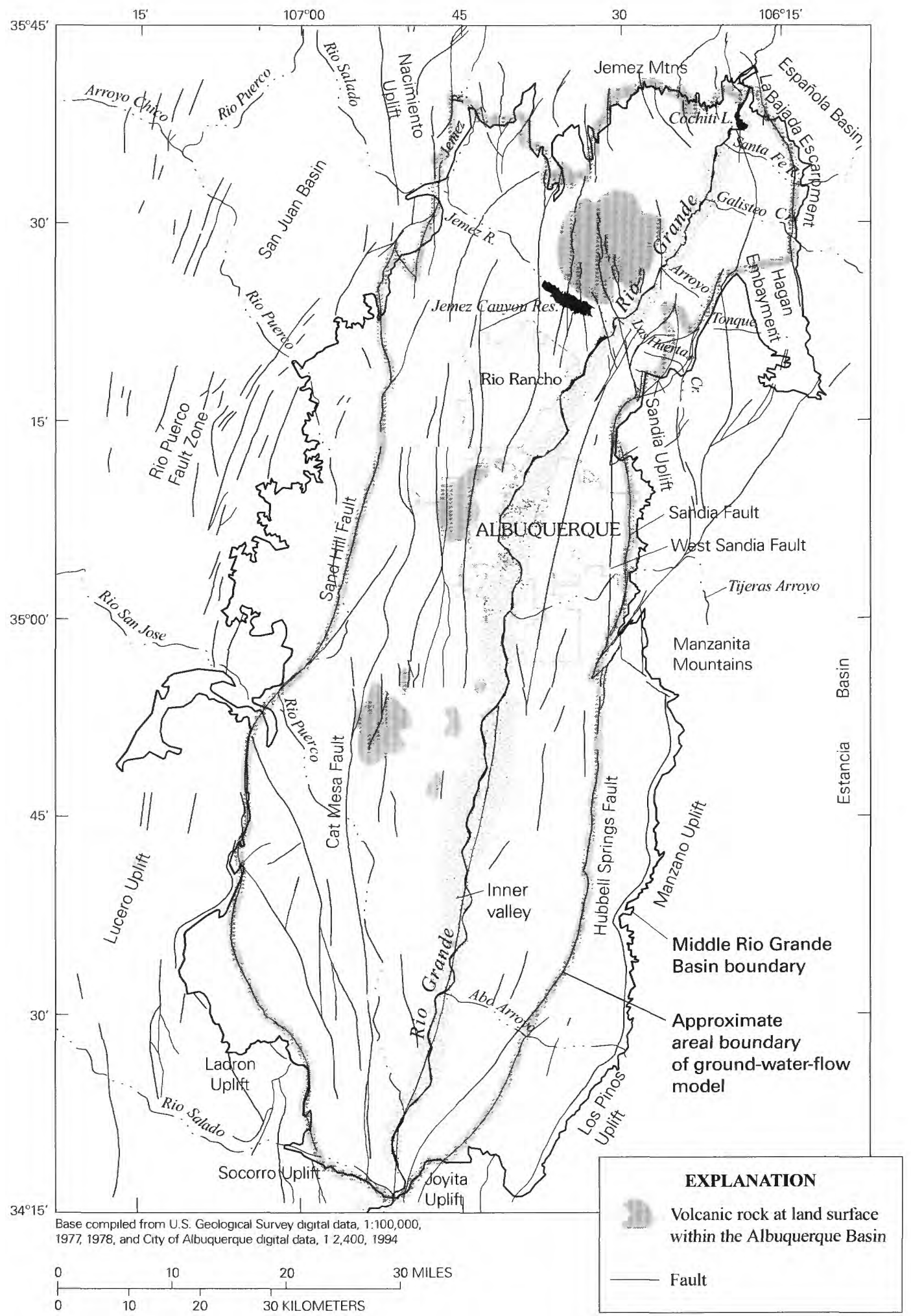

Figure 3. Major geologic and tectonic features in the vicinity of the Middle Rio Grande Basin (modified from Kelley, 1977; Thorn and others, 1993, fig. 4; Kernodle, 1998, fig. 14). 
about $5 \mathrm{Ma}$, with tectonism active mostly from about $15 \mathrm{Ma}$ to $5 \mathrm{Ma}$ (Thorn and others, 1993). Structural boundaries of the basin are the Nacimiento Uplift to the northwest, the Jemez Mountains to the north, the La Bajada Escarpment to the northeast, the Sandia and Manzano Uplifts to the east, the Los Pinos Uplift to the southeast, the Socorro and Joyita Uplifts to the south, the Ladron Uplift to the southwest, and the Lucero Uplift and the Rio Puerco Fault Zone to the west (fig. 3). The MRGB is defined as the extent of Cenozoic deposits within these structural boundaries. The Rio Grande flows into the basin through the northeastern constriction and out of the basin through the southern constriction, where eastern and western structural features converge. Basin fill is continuous across the northeastern and southern boundaries (Hawley and Haase, 1992).

Rock units in the MRGB include pre-Santa Fe Tertiary deposits, Tertiary Santa Fe Group basin fill, post-Santa Fe Pleistocene volcanic rock, and post-Santa Fe Quaternary sediments. The following discussion of the depositional history, lithology, and thicknesses of the Santa Fe and post-Santa Fe deposits is condensed from Hawley and Haase (1992) and Thorn and others (1993); these works describe the understanding of the geologic history and depositional structure of the basin as of the mid-1990s. The predominant basin deposit is the Santa Fe Group, the thickness of which ranges from about 3,000 feet along the basin margins to greater than 14,000 feet in the basin center. The lower units in the Santa Fe Group were deposited during the Oligocene and Miocene from about $30 \mathrm{Ma}$ to $15 \mathrm{Ma}$, when the basin was internally drained, and contain piedmont-slope, eolian, and basin-floor playa deposits. The middle units of the Santa Fe Group were deposited during the Miocene and early Pliocene from about $15 \mathrm{Ma}$ to $5 \mathrm{Ma}$, the time of greatest accumulation of sediments in the basin. During that time, piedmont-slope deposition continued and fluvial systems developed, transporting sediment into the basin, but most likely terminating in playa lakes within the basin. The upper units of the Santa Fe Group were deposited during the Pliocene from about 5 to $2.7 \mathrm{Ma}$. The ancestral Rio Grande developed at the end of this time, entering the basin from the north and flowing out to the south. The axial-channel sands and gravels associated with the ancestral Rio Grande are especially coarse and well sorted, but thin. The sands of the middle and lower units of the Santa Fe Group tend to be finer-grained and less well sorted.

Geologic and geophysical studies have since been conducted to further characterize the location, extent, and properties of the depositional units in the basin (Bartolino and Cole, 2002). Much of that work was compiled into a three-dimensional geologic model of the basin (Cole, 2001b), upon which the hydraulic conductivity zonation of the ground-water-flow model in this study has been based.

The crustal extension that formed the Rio Grande Rift caused normal faults to develop throughout the MRGB during deposition of the Santa Fe Group. Pliocene and younger faults have a predominantly north-south orientation (fig. 3). At the basin margins and at depth in the central parts of the basin, the normal faulting placed older, less permeable rock adjacent to parts of the Santa Fe Group. Total vertical displacements along these faults are up to 30,000 feet (Hawley and others, 1995, p. 45). Normal faulting also occurred within the Santa Fe Group deposits, and some of these faults have been cemented and act as partial barriers to horizontal ground-water flow. Basalt flowed to the land surface along presumed fault zones and was emplaced in the central part of the basin from about 4 to $2.5 \mathrm{Ma}$ (Love and others, 1994). Outcrops of this rock occupy a small percentage of the basin surface area, although recent aeromagnetic studies indicate that the basalt is much more extensive in the subsurface (Grauch and others, 2001).

\section{Hydraulic Properties}

Many aquifer tests have been performed and analyzed to estimate the hydraulic conductivity and transmissivity of deposits within the Santa Fe Group. Most tests were conducted in public-supply wells with screens that are a few hundred feet long. Thorn and others (1993, table Al, pages 75-81) summarized the results of several of these aquifer tests and reported the hydraulic-conductivity estimate for each well as the transmissivity divided by the screen length. Hydraulic-conductivity estimates for over 20 wells completed only in the upper part of the Santa Fe Group range from 4 to 130 feet per day. Sandy, pebble-gravel deposits of the upper part of the Santa Fe Group that are beneath the City of Albuquerque generally have the highest hydraulic conductivities. Hydraulic-conductivity estimates for nine wells with screens that penetrate both the upper and middle Santa Fe Group range from 7 to 71 feet per day. Additional tests were performed in several wells for which the lithology is unknown. Deposits in the Rio Grande alluvium can vary from silty clay to coarse gravel. Cummins (1997) estimated the hydraulic conductivity of coarse-grained alluvium deposits to be between 90 and 350 feet per day. Willis (1993) estimated the hydraulic conductivity for silty clay and gravelly coarse sand within the alluvium to be 0.2 and 65 feet per day, respectively.

In their models of ground-water flow within the basin, Kernodle and others (1995) assigned horizontal hydraulic conductivities on the basis of field tests and on compiled unit descriptions from Hawley and Haase (1992). These assigned values ranged from 2 feet per day for the lower Santa Fe Group deposits to 70 feet per day for the axial-channel gravel deposits. Tiedeman and others (1998) calibrated a groundwater-flow model of the basin based on water levels and seepage estimates from the Rio Grande in the vicinity of Albuquerque. These calibrated hydraulic conductivities ranged from about 2 feet per day for the lower Santa Fe Group deposits to about 100 feet per day for the Rio Grande alluvium and the axial-channel deposits. McAda and Barroll (2002) used values in their recent model that varied between 0.5 and 45 feet per day. Presently, there are no field measurements of the ratio of horizontal to vertical hydraulic conductivity for deposits in the MRGB. The ratio used by Kernodle and others (1995) was 300:1, that used by McAda and Barroll (2002) was 150:1, 
whereas the value calibrated by Tiedeman and others (1998) ranged from 330:1 to $3,500: 1$, depending upon the other assumptions made in the model.

\section{Hydrologic Conditions}

The following discussions of the hydrologic conditions of the MRGB are condensed from the more detailed descriptions given by Thorn and others (1993), McAda (1996), Bexfield and Anderholm (2000), and McAda and Barroll (2002).

\section{Ground-Water Levels}

Regional ground-water levels that represent predevelopment conditions have been compiled by Bexfield and Anderholm (2000), and are shown in figure 4. The ground-water levels that were used to construct this figure were from different depths and have different screened interval lengths; thus, the water-level contours depict large-scale horizontal groundwater movement through the basin, but do not accurately represent smaller scale ground-water-flow conditions. In addition, uniformly spaced contours are shown in some areas of sparse data, whereas the horizontal hydraulic gradient may be more variable in the true flow system. Some ground water flows from the flanks of the basin inward toward the Rio Grande, but the predominant direction of flow is through the basin from north to south. The Rio Grande was losing water to the basin aquifer under predevelopment conditions in a reach just north of the city of Albuquerque. This water moves into the aquifer system away from both sides of the Rio Grande and flows southward parallel to the river until it discharges back into the Rio Grande along an extended reach in the southern part of the basin. The extent of the losing reach of the Rio Grande has increased toward the south as increasing ground-water extractions over the last 50 years in the vicinity of the city of Albuquerque have induced more leakage. In one region west of the Rio Grande and the city of Albuquerque, ground-water levels are lower than those in the Rio Grande just to the east. This area, known as the "trough," was originally described by Meeks (1949), Bjorklund and Maxwell (1961), and Titus (1963), and has been the subject of speculation ever since as to its cause. Tiedeman and others (1998) performed numerical experiments to test different hypotheses, including a northsouth-trending fault zone, the presence of a unit of greater hydraulic conductivity, and a greater thickness of permeable sediments. The results were equivocal and no single hypothesis could be supported fully by the field evidence.

Today, the inner valley (fig. 2) of the MRGB is networked with an extensive system of canals and drains that greatly affect and control the ground-water levels there, but these effects are not shown in the predevelopment map (fig. 4) because their impact on more regional water levels is limited. Although irrigation practices have been undertaken in the inner valley for more than a century, extensive ground-water development for public supply in the Albuquerque area began in the 1950s. Thus for the present study, a predevelopment water-level configuration refers to levels occurring before approximately 1950. The Cochiti and Jemez Canyon Dams in the northern part of the basin are relatively recent and are not predevelopment features. Because the focus of this study is on the calibration of a ground-water model to predevelopment conditions, all of the manmade hydrologic features will receive no further discussion in this report.

\section{Rio Grande}

The position and geometry of the Rio Grande channel have changed over time because of natural and anthropogenic activities, as evidenced by data back to 1935 that are stored in Geographical Information Systems (GIS) of the USGS and the Bureau of Reclamation. The river channel is locally incised into the inner valley of the basin, and the Rio Grande water level generally is within a few feet of the land surface. Land-surface altitude is available from USGS 1:24,000-scale topographic maps and varies at the river channel from about 4,690 feet above sea level at the southern edge of the basin to about 5,240 feet above sea level at the northern edge of the basin. The mean annual flow in the Rio Grande in the MRGB between the years of 1974 and 1992 was about 1 million acrefeet. The bottom consists of coarse sand that is about 3 feet thick (Gould, 1997), usually underlain by finer grained deposits. Although reliable field estimates of the vertical hydraulic conductivity of the river bed have not been made, the location and extent of some clay-rich layers beneath the flood plain have been mapped in the vicinity of Albuquerque (Bartolino and Sterling, 1999).

\section{Recharge}

The ground-water flow system of the MRGB has several sources of recharge. Precipitation in the mountains infiltrates along mountain fronts bordering the basin, and surface water infiltrates along streams and arroyos that are tributaries to the Rio Grande. Ground-water inflow from adjacent basins and mountains recharges as underflow to the northern and southwestern parts of the basin. Substantial ground-water withdrawals in the Albuquerque area have lowered water levels beneath the Rio Grande and subsequently induced recharge from the river. Recharge also occurred naturally as leakage from the Rio Grande along reaches from just north of Albuquerque to as far south as Belen.

Recharge along the mountain fronts and tributaries to the Rio Grande was estimated in the past using the rainfallrunoff and water-budget methods described by Hearne and Dewey (1988) and Waltemeyer (1994). Kernodle and Scott (1986) and Kernodle and others (1995) used and modified this type of data for values of recharge that were input to their ground-water-flow models (fig. 5). Using these methods, the total recharge along the eastern side of the basin was estimated to be 71,700 acre-feet per year. Tiedeman and others (1998) calibrated a ground-water-flow model of the basin and adjusted some of the recharge values to obtain a better fit with the water-level and streamflow data. Their estimates 


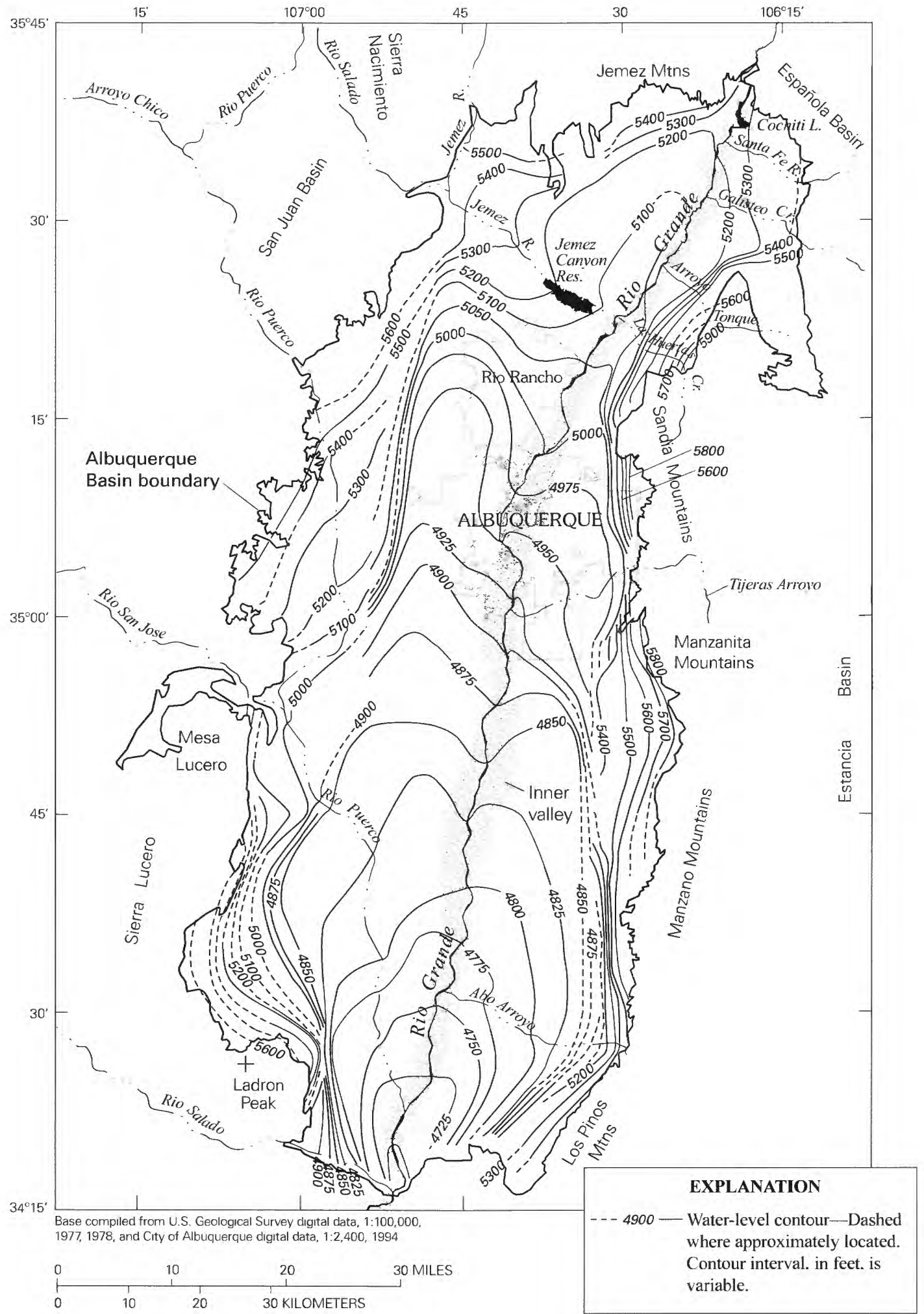

Figure 4. Water table in its predevelopment configuration (modified from Bexfield and Anderholm, 2000). 


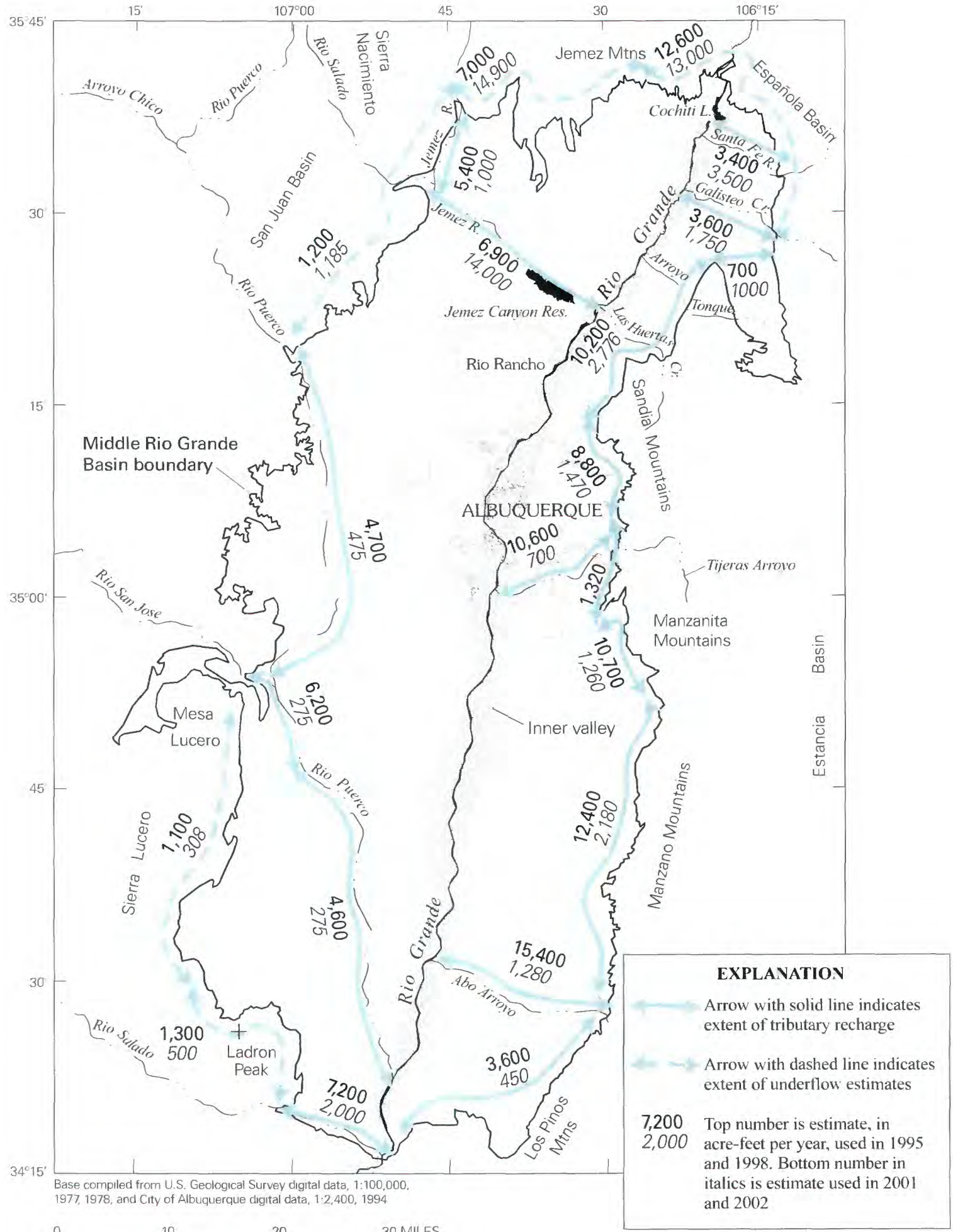

Figure 5. Mountain-front recharge, tributary recharge (solid lines), and underflow estimates (dashed lines), in acre-feet per year, used by Kernodle and others (1995) and Tiedeman and others (1998), and estimates used by McAda and Barroll (2002) (italics) that include those of Anderholm (2001). 
were typically from one-half to three-fourths of those from the water-budget methods. Anderholm (2001) estimated recharge along the eastern mountain fronts by using the chloride massbalance method. His estimates of recharge were significantly lower, with a total recharge value for the eastern side of the basin being about 11.200 acre-feet per year. The difference in the estimates between the water-budget and chloride mass-balance methods can be explained if surface-water runoff from the mountains that is initially recharged undergoes significant loss due to evapotranspiration (Anderholm. 2001), because the water-budget methods assume these evaporation losses are negligible. McAda and Barroll (2002) used a combination of recharge estimates from the water-budget and chloride massbalance methods (fig. 5 ).

Numerical modeling of ground-water flow in basins adjacent to the MRGB suggests that there is ground-water inflow to the northern and western parts of the basin (Frenzel, 1995; Hawley and Grant, 1997). Using a model of ground-water flow in the Española Basin, McAda and Wasiolek (1988) estimated ground-water flow from that basin to the MRGB to be 12,600 acre-feet per year. Kernodle and others (1995) estimated ground-water inflow from the Jemez Mountains by assuming the ground-water inflow per unit length of the boundary was the same as that entering from the Española Basin. In their model of ground-water flow in the San Juan Basin, Frenzel and Lyford (1982) estimated ground-water underflow to the MRGB to be 1,200 acre-feet per year. Using a water-budget method, J. D. Dewey (Hydrologist, U.S. Geological Survey, written commun., 1982) estimated total underflow from the Sierra Lucero and Ladron Peak region into the MRGB to be about 2,400 acre-feet per year.

\section{Discharge}

Under predevelopment conditions, ground water discharged from the MRGB by flow into the Rio Grande, by underflow to the Socorro Basin at the southern end of the basin near San Acacia, and by evapotranspiration in the inner valley. Discharge to the Rio Grande contributes base flow to the river, especially in the northernmost and southernmost reaches in the basin, but because this amount is small relative to the entire flow in the river, the amount has not been measured in the field. Underflow to the Socorro Basin has been considered small compared to other budget components (Kernodle and Scott, 1986) and therefore has been neglected in all modeling studies. The Bureau of Reclamation (1973) estimated in field studies that about 3 feet per year of water is evapotranspired by tamarisk and Russian olives, two riparian species that grow in the inner valley. Using this rate, Thorn and others (1993) estimated that transpiration by riparian vegetation in the inner valley is 112,000 acre-feet per year. Similarly, they used rates from a study by Blaney and others $(1938)$ and estimated evapotranspiration from wetlands to be 13,500 acre-feet per year. Much of this evapotranspired water would originate from the adjacent Rio Grande and not necessarily be water that had recharged along distant boundaries of the basin.

\section{Geochemical Conditions}

Geochemical data for ground water in the MRGB has been compiled, collected, and analyzed by Anderholm (1988) and Logan (1990), and more recently and extensively by Bexfield and Anderholm (2002) and Plummer and others (2004) as part of the multi-year MRGB study. The data by Plummer and others (2004) include major and minor-element chemistry (30 elements), ${ }^{18} \mathrm{O}$ and $\delta^{2} \mathrm{H}$ in water, ${ }^{13} \mathrm{C}$ and ${ }^{14} \mathrm{C}$ of dissolved inorganic carbon (DIC). ${ }^{34} \mathrm{~S}$ of dissolved sulfate, tritium $\left({ }^{3} \mathrm{H}\right)$, and selected dissolved gases (including dissolved oxygen, nitrogen, argon, methane, helium, tritiogenic helium-3 $\left({ }^{3} \mathrm{He}\right)$, chlorofluorocarbons (CFCs: CFC-11, CFC-12, CFC113), sulfur hexafluoride ( $\left.\mathrm{SF}_{6}\right)$, neon, and carbon dioxide). Most of the chemical and isotopic data are from relatively shallow depths - typically the upper 150 feet of aquifer-but some data are from depths of more than 1,500 feet below the water table. The chemical and isotopic composition of ground water in the MRGB was mapped (for example, see figs. 6-8) and used to identify 13 water-quality zones that have unique chemical and isotopic characteristics (fig. 9). The water-quality zones were interpreted as representing sources of recharge to the basin (zones 1-12) or ground-water discharge from the basin (zone 13). The classification is based on existing waterquality data and new analyses from 288 wells and springs.

Most of the discussion that follows is a summary from Plummer and others (2004). Most chemical and isotopic data align parallel to the predominant north to south direction of ground-water flow throughout the basin and show a small but distinguishable effect of geochemical reactions on radiocarbon activity. The ${ }^{14} \mathrm{C}$ ages of DIC were adjusted for the geochemical reactions, and the ages ranged from modern to more than 30,000 years before present. Deuterium, $\delta^{2} \mathbf{H}$, was useful in delineating sources of ground water in the basin (fig. 7). Based on 72 samples collected between 1996 and 1999, the median $\delta^{2} \mathrm{H}$ content of Rio Grande water is $-89.9 \%$, and based on 20 samples from the same time period, the median $\delta^{2} \mathrm{H}$ content of mountain-front recharge water at the base of the Sandia Mountains is $-83.5 \%$. More limited isotopic data from the Jemez River near Jemez and the Rio Puerco near Highway 6 indicate mean $\delta^{2} \mathrm{H}$ values of -83.6 and $-58.6 \%$, respectively.

The median values for selected water-quality parameters that are characteristic for each hydrochemical zone are summarized in table 1 . Zone recognition was based on varied subsets of the chemical and isotopic constituents. Zone 1 (northern mountain-front recharge) is in the northeast part of the basin and is thought to be water recharged along the southern flanks of the Jemez Mountains (fig. 9). Zone 1 water is characterized by relatively low specific conductance and $\mathrm{pH}$, and higher than average $\delta^{2} \mathrm{H}$ and dissolved $\mathrm{SiO}_{2}$ for the basin, and has a median radiocarbon age of 8,800 years. The saturated thickness of zone 1 is greater than 200 feet at the northeast basin margin but may be relatively thin (50 feet) elsewhere. Zone 2 (northern intra-basin recharge) is thought to represent lower elevation recharge from arroyos in the northern part of the basin (fig. 9). Some distinguishing characteristics of 


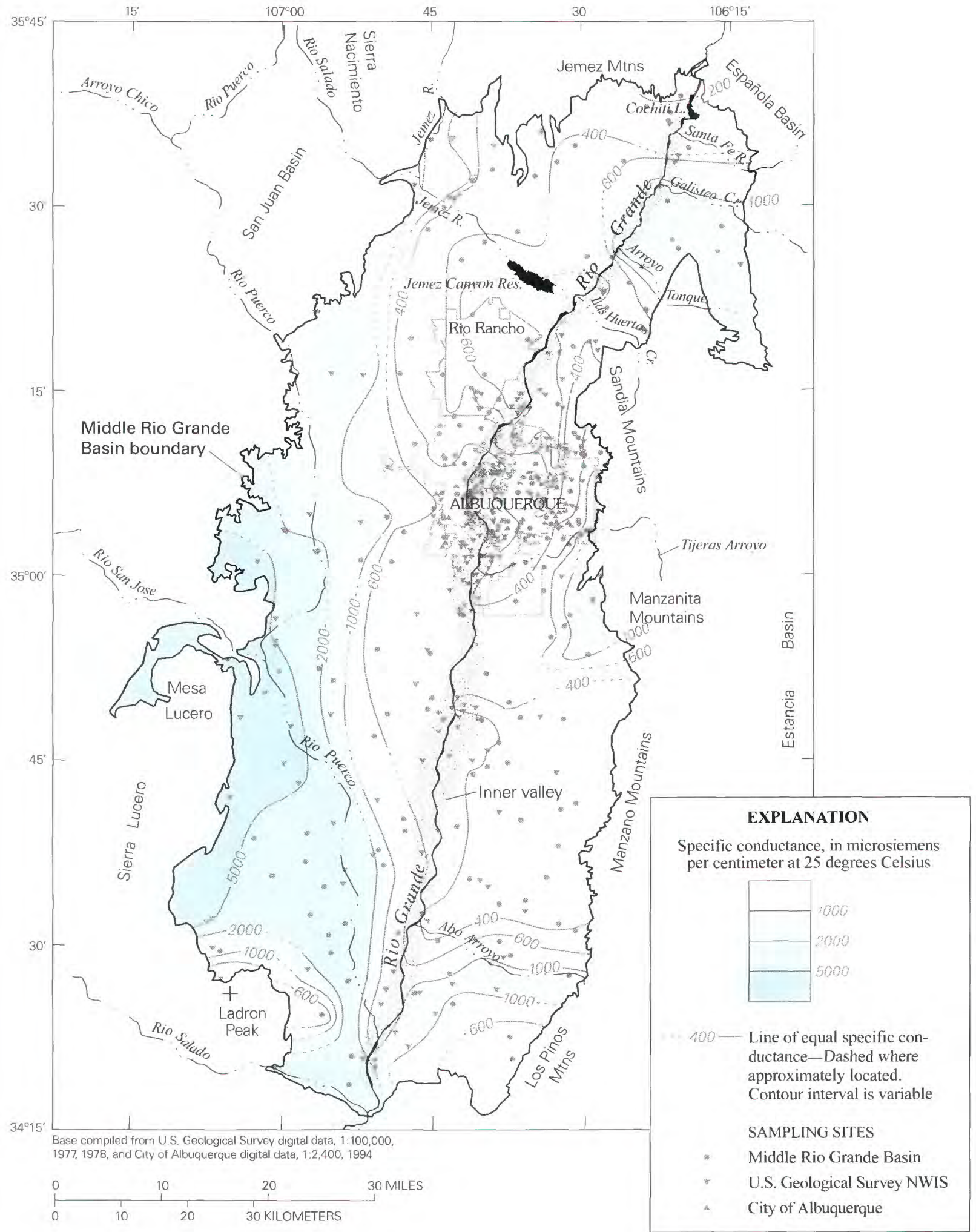

Figure 6. Specific conductance in ground water of the Middle Rio Grande Basin (from Plummer and others, 2004). 


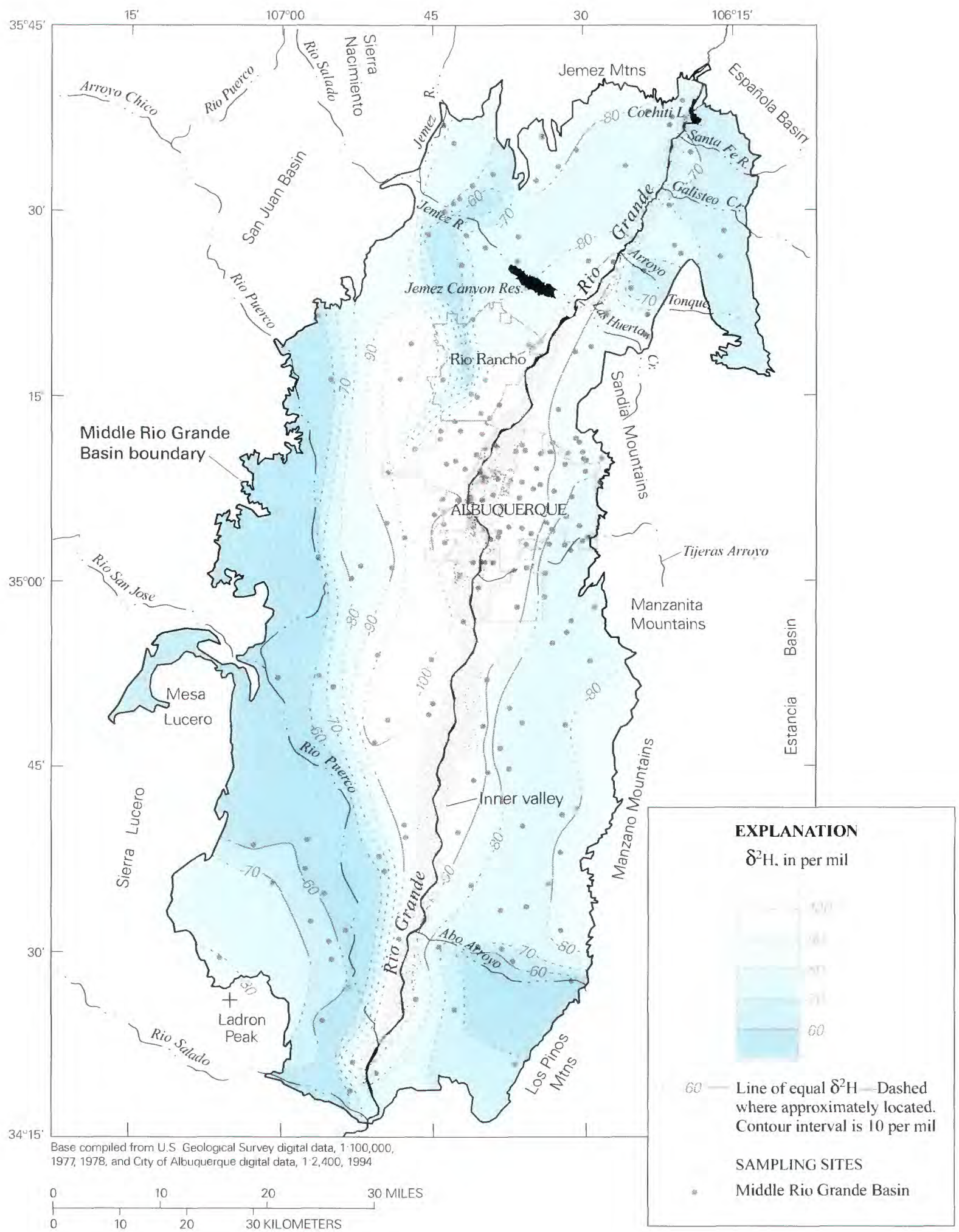

Figure 7. Contours of deuterium composition, $\delta^{2} \mathrm{H}$, for ground water of the Middle Rio Grande Basin (from Plummer and others, 2004). 


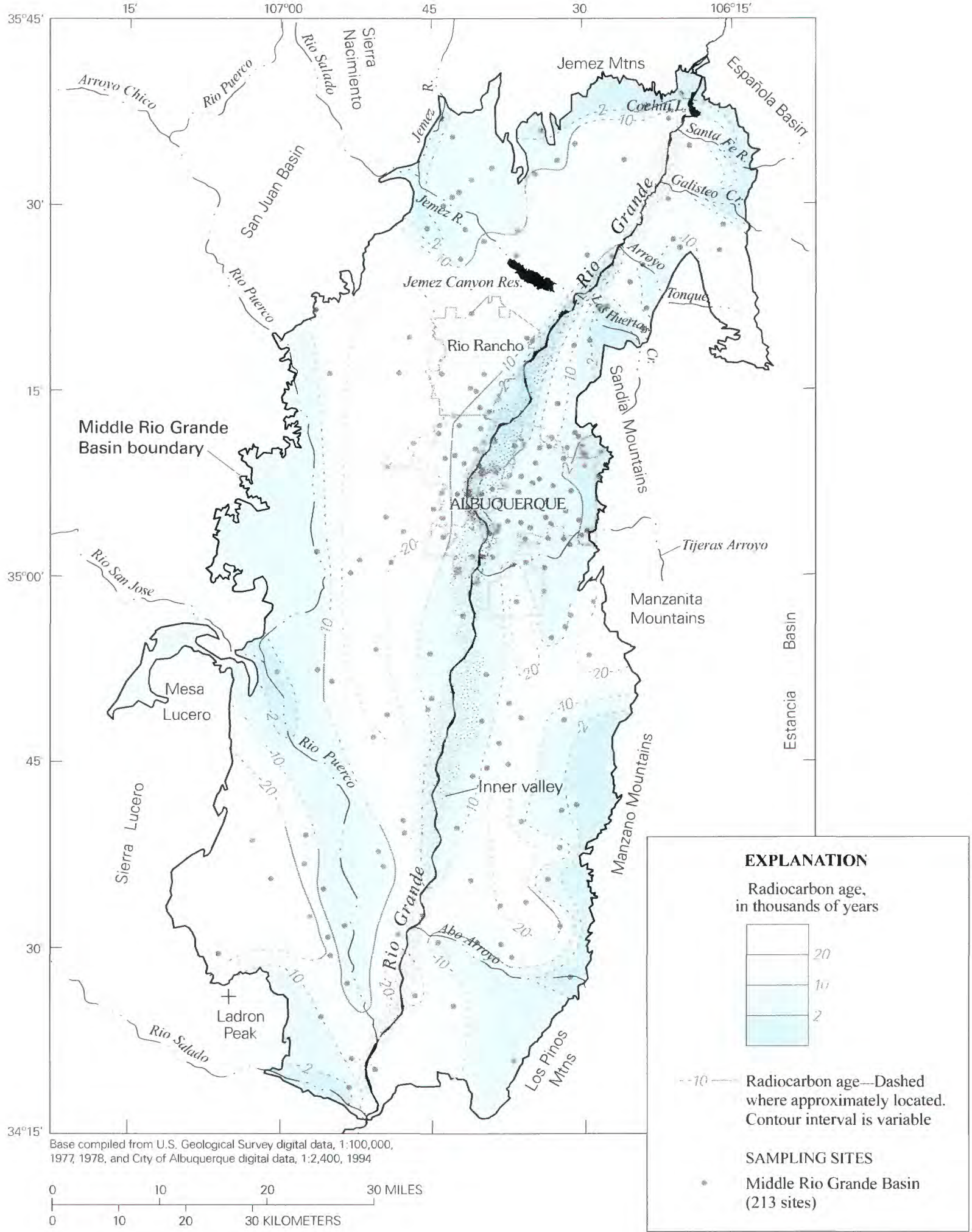

Figure 8. Contours of conventional radiocarbon age of DIC (dissolved inorganic carbon) in ground water of the Middle Rio Grande Basin (from Plummer and others, 2004). 


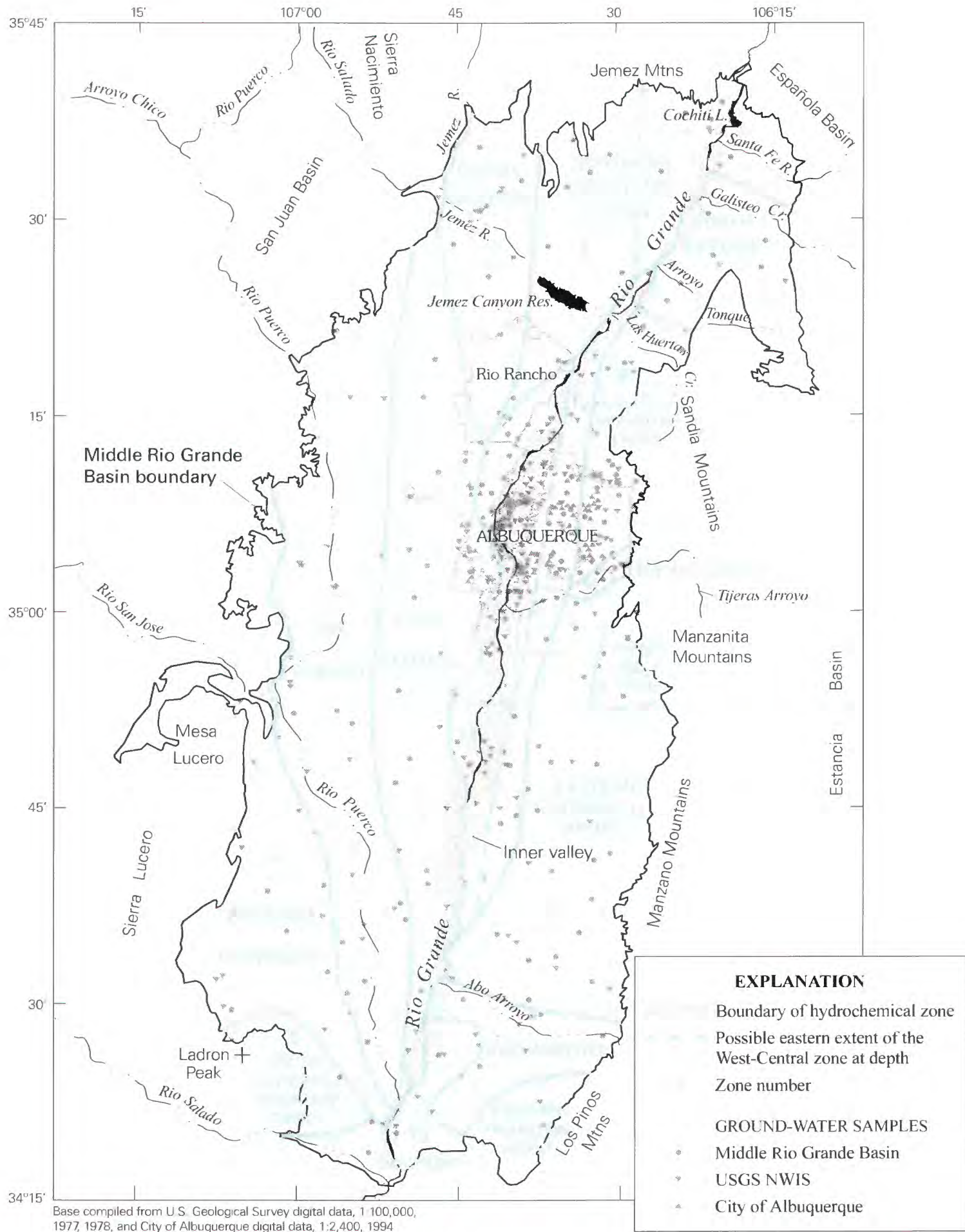

30 MILES

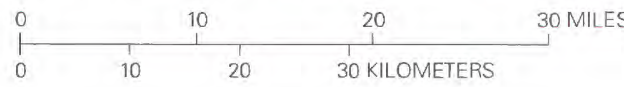

Figure 9. Hydrochemical zones in the Middle Rio Grande Basin (from Plummer and others, 2004). 
zone 2 water are lower than average specific conductance and dissolved $\mathrm{SiO}_{2}$, and higher than average $\delta^{2} \mathrm{H}$ and dissolved nitrate. Zone 2 has a median age of water of 8,800 years, and a saturated thickness of possibly less than 200 feet.

Zone 3 (inflow along the northern basin margin) occurs beneath zones 1 and 2 in the northern part of the basin, extends under part of zone 12 that parallels the Rio Grande, and occurs at the water table throughout the central part of the basin, converging at the Rio Grande in the southern basin (fig. 9). Zone 3 contains some of the oldest waters sampled in the basin, with a median age of 19,900 years, and is thought to represent recharge from the Jemez Mountains north of the basin, primarily during the last glacial period. Zone 3 water is a $\mathrm{Na}-\mathrm{HCO}_{3}-$ $\mathrm{SO}_{4}$-type water with higher than average specific conductance, arsenic, vanadium, and $\mathrm{pH}$. Relative to zones 1 and 2 , zone 3 water is high in dissolved sulfate, but very depleted in $\delta^{2} \mathrm{H}$. Zone 4 (inflow from the western basin margin) contains old ground water that seeps into the basin from Pennsylvanian through Cretaceous sedimentary rocks along the western basin margin (fig. 9). Zone 4 water has some of the highest specific conductance values in the basin, along with higher than average $\delta^{2} \mathrm{H}$ and chloride, and is predominantly a $\mathrm{Na}-\mathrm{Cl}-\mathrm{SO}_{4}$-type water. The median age of zone 4 water is 20,400 years. Zone 4 water is likely to occur to considerable depth in the southwest part of the basin, but this cannot be directly determined from the relatively shallow windmills sampled. Water in zone 4 may become diluted by infiltration water in the basin and mixing with water from the Rio Puerco.

Zone 5 occurs parallel to the Rio Puerco throughout the basin and contains water infiltrated from it. It is predominantly a $\mathrm{Na}-\mathrm{SO}_{4}$-type water, and is characterized by higher than average $\delta^{2} \mathrm{H}$, specific conductance, and sulfate. The median age is 8,100 years, but the water is younger nearer the Rio Puerco. Zone 5 water occurs down to at least 250 feet below the water table. Zone 6 (southwestern mountain-front recharge) occurs in the southwest corner of the basin and probably represents recharge occurring along the flanks of Ladron Peak. Only two water samples were identified from this source; they have lower than average specific conductance and dissolved sulfate. The water appears to be a $\mathrm{Na}-\mathrm{Ca}-\mathrm{Mg}-\mathrm{HCO}_{3}-$ type water, with higher than average $\delta^{2} \mathrm{H}$. Total saturated thickness of this zone is unknown. The mean radiocarbon age is 7,700 years.

Zone 7 (recharge from Abo Arroyo) occurs in the southeastern part of the basin and appears to be eastern mountain-front recharge affected by infiltration from Abo Arroyo. The water is a Ca-SO type, and is characterized by higher than average specific conductance, sulfate, and chloride. The median age is 9,400 years and flow is generally to the westsouthwest to the Rio Grande. The limited depth information indicates total saturated thickness of at least 80 feet. Zone 8 (eastern mountain-front recharge) occurs along the entire eastern mountain front and represents recharge from that source (fig. 9). The water is a $\mathrm{Ca}-\mathrm{Na}-\mathrm{HCO}_{3}$ type, and is characterized by lower than average specific conductance, $\delta^{2} \mathrm{H}$, chloride, and $\delta^{13} \mathrm{C}$. Elevated concentrations of sulfur hexafluoride released from fluid inclusions in granitic rock were detected along the eastern mountain front. Eastern mountain-front water has a median age of 5,200 years. The saturated thickness in zone 8 may be more than 800 feet.

Zone 9 (ground-water inflow from the Tijeras Fault Zone) occurs along the eastern mountain front south of Tijeras Arroyo, and appears to represent water from crystalline rocks along the Tijeras Fault Zone that have mixed with eastern mountain-front recharge water (zone 8). Zone 9 water is characterized by higher than average specific conductance, $\delta^{2} \mathrm{H}$, boron, $\delta^{13} \mathrm{C}$, chloride, bicarbonate, and lithium. The median age is 16,300 years. Zone 10 (recharge from Tijeras Arroyo) occurs in a narrow zone along Tijeras Arroyo and appears to be mountain-front recharge affected by infiltration from Tijeras Arroyo. This water is a $\mathrm{Ca}-\mathrm{HCO}_{3}$-type water, and is characterized by higher than average specific conductance, sulfate, nitrate, and $\delta^{2} \mathrm{H}$. The median age of waters sampled from zone 10 was only 3,200 years, and some waters contained tritium and chlorofluorocarbons.

Zone 11 (inflow from the northeast basin margin) occurs along the northeast side of the basin and appears to be a mixture of inflow from the Hagan Embayment (fig. 3), mountainfront recharge, and arroyo recharge. The water is characterized by higher than average specific conductance, chloride, calcium, sulfate, $\delta^{2} \mathrm{H}$, sodium, and $\delta^{13} \mathrm{C}$. The median radiocarbon age is 10,000 years but appears older nearest the basin margin, suggesting that inflow from the adjacent Hagan Embayment contains relatively old water. Zone 12 (recharge from the Rio Grande) occurs parallel to the Rio Grande from about San Felipe Pueblo (fig. 4) in the northern basin to Abo Arroyo in the south. Zone 12 appears to represent infiltration from the Rio Grande and occurs slightly west of the Rio Grande and as much as 7 miles east of the Rio Grande at Albuquerque. The zone is relatively narrow in its extreme northern and southern extents (fig. 9). The water from zone 12 contains lower than average $\delta^{2} \mathrm{H}, \delta^{34} \mathrm{~S}$ of sulfate, dissolved oxygen, and sulfate. Zone 12 water contains higher than average dissolved $\mathrm{SiO}_{2}$ and potassium, with calcium elevated relative to sodium. The median age is 4,300 years, and the saturated thickness in zone 12 is more than 1,400 feet beneath parts of Albuquerque. Zone 12 water has lower $\mathrm{pH}$, sulfate, radiocarbon age, and higher calcium than water from zone 3 , which occurs under about the western third of zone 12 .

Zone 13 (basin discharge) was recognized in seven samples from the southern tip of the basin (fig. 9) and is thought to represent an area of convergence of flow lines due to reduction in thickness and lateral extent of basin-fill material. Zone 13 water has higher than average specific conductance, sulfate, chloride, lithium, and boron. The median chloride content is elevated relative to chloride in adjacent zones, possibly indicating upward movement of water from deeper parts of the basin. Zone-13 water has lower than average $\delta^{2} \mathrm{H}$, and lower than average dissolved oxygen. The median age of zone 13 water is 17,900 years. 


\section{GROUND-WATER-FLOW MODEL}

\section{Numerical Methods}

Transient, three-dimensional ground-water flow through heterogeneous, anisotropic, porous media is governed by the following partial differential equation (Freeze and Cherry, 1979):

$$
\frac{\partial}{\partial x}\left(K_{u} \frac{\partial h}{\partial x}\right)+\frac{\partial}{\partial y}\left(K_{v} \frac{\partial h}{\partial y}\right)+\frac{\partial}{\partial z}\left(K_{z:} \frac{\partial h}{\partial z}\right)-W=S_{v} \frac{\partial h}{\partial t}
$$

where

$x, y=$ cartesian coordinates in the horizontal direction $(\mathrm{L})$;

$z \quad=$ cartesian coordinate in the vertical direction $(\mathrm{L})$;

$K_{1,}, K_{1,}, K_{--}$

$=$ hydraulic conductivity in the $\mathrm{x}, \mathrm{y}$, and $\mathrm{z}$ directions (LT-1);

$h \quad=$ hydraulic head, or water level (L);

$W \quad=$ volumetric flux of an external source or sink, per unit volume (L);

Ss $=$ specific storage $\left(\mathrm{L}^{-1}\right) ;$ and

$t \quad=$ time .

The USGS MODFLOW model (McDonald and Harbaugh, 1988) implements an integrated finite-difference approximation of equation 1. The MODFLOW model was used to simulate ground-water flow in the MRGB using the preconditioned conjugate-gradient solver (Hill, 1990). The hydrogeologic deposits are allowed to be anisotropic in the horizontal direction, but only by a single constant factor for each layer. Vertical anisotropy can vary horizontally, though, as vertical and horizontal conductivity can be specified independently throughout the three-dimensional domain. A steady-state assumption was made in the first part of this study for simulating predevelopment conditions, but later transient simulations were made to accommodate possible varying past rates of recharge. Travel times to wells sampled for ${ }^{1+} \mathrm{C}$ were calculated using the USGS MODPATH model (Pollock, 1994). The model uses the cell-by-cell fluxes calculated with MODFLOW to track flow lines backward from wells to recharge locations. The curvatures of the flow lines are calculated through each cell by assuming a linear change in velocity between the cell faces along each coordinate direction. The MODPATH model was also used to delineate how waters from different source regions were simulated by MODFLOW to be distributed across the basin. The MODFLOW and MODPATH representations of the basin were calibrated in part using nonlinear regression methods implemented in UCODE (Poeter and Hill, 1998).

\section{Spatial Discretization}

Although the MRGB is defined as the extent of Cenozoic deposits within the bounding structural uplifts, the model domain covers a somewhat smaller area. The eastern and western model boundaries are mostly coincident with faults thought to be partial barriers to horizontal ground-water movement (fig. 3). The model boundaries in the north and south coincide with the boundaries of the MRGB, which are defined by mountains and uplifts. The areal model extent is the same as in the earlier models of Kernodle and others (1995) and Tiedeman and others (1998). The overall horizontal discretization is somewhat coarser than that of Kernodle and others (1995), yet somewhat finer than that of Tiedeman and others (1998). The model area is divided into a rectilinear grid of equally spaced 1-kilometer-size cells composing 156 rows and 80 columns (fig. 10).

The vertical extent of the aquifer system is represented by nine model layers. Kernodle and others (1995) used 11 layers, whereas Tiedeman and others (1998) used 6 to 9. The bottom of layer 1 is 20 feet below the bed of the Rio Grande, and the altitude of the bottom of layer 1 is constant in an orthogonal direction away from the trend of the inner valley (fig. 11). The upper seven layers range in thickness from 20 to 1,000 feet and extend to a depth of about 2,400 feet below the elevation of the Rio Grande. Layers 8 and 9 are of variable thickness and represent the aquifer system from the bottom of model layer 7 to the base of the Santa Fe Group (fig. 12). Layer 8 ranges in thickness from about 400 to 3,000 feet, and layer 9 ranges in thickness from about 800 to 6,000 feet. The total thickness of the model is about 12,000 feet, although the deeper depths are represented by coarser layering because geologic data there are sparse, and water-level data are nonexistent. This is a significant change from the earlier models of Kernodle and others (1985) and Tiedeman and others (1998), which extended to depths of only 1,730 feet and 5,000 feet, respectively. The basin thins near its margins; therefore, the number of active cells in each model layer is smaller for successively deeper layers. Layer 1 contains about 6,200 active cells, and layer 9 contains about 4,500 active cells. The model contains a total of about 51,000 active cells.

\section{Boundary Conditions}

Boundary conditions include no flow on the bottom of the model domain, no flow and specified flow on the sides of the model domain, and head-dependent flow and specified flow on the top of the model domain. For each boundary condition, an associated parameter was estimated during model calibration with aid of the nonlinear regression procedure within UCODE. Manual adjustments of individual parameters were also made to further minimize the model error. The best parameter estimates from Tiedeman and others (1998) were used as the initial parameter values at the outset of the calibration procedure.

\section{Head-Dependent River Boundary Conditions}

Head-dependent boundaries are implemented in the inner valley of the MRGB to represent the interaction of the Rio Grande with the ground-water-flow system. Likewise, head-dependent boundaries are implemented along the Jemez 


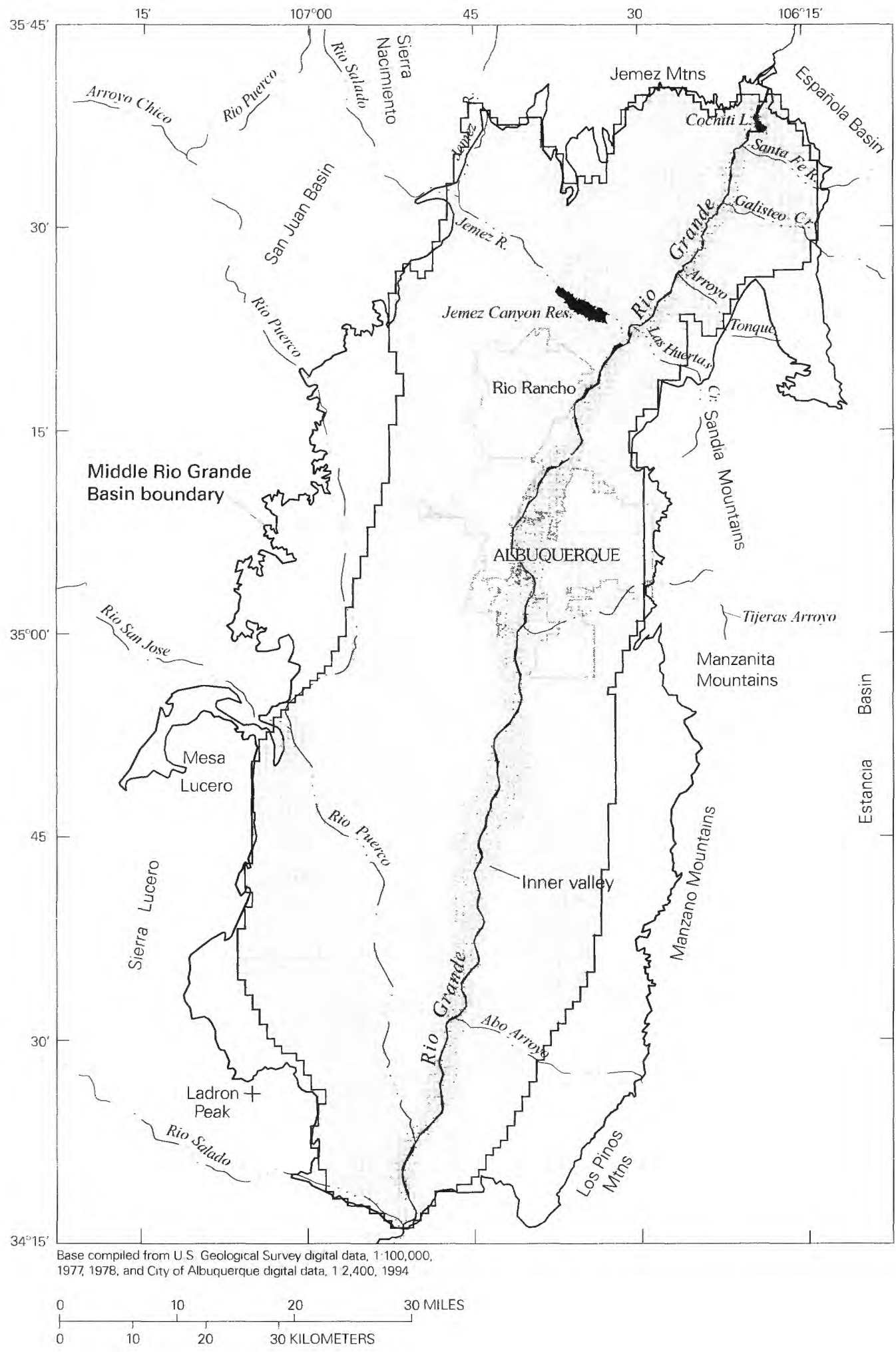

Figure 10. Plan view of finite-difference grid for the ground-water-flow model. 


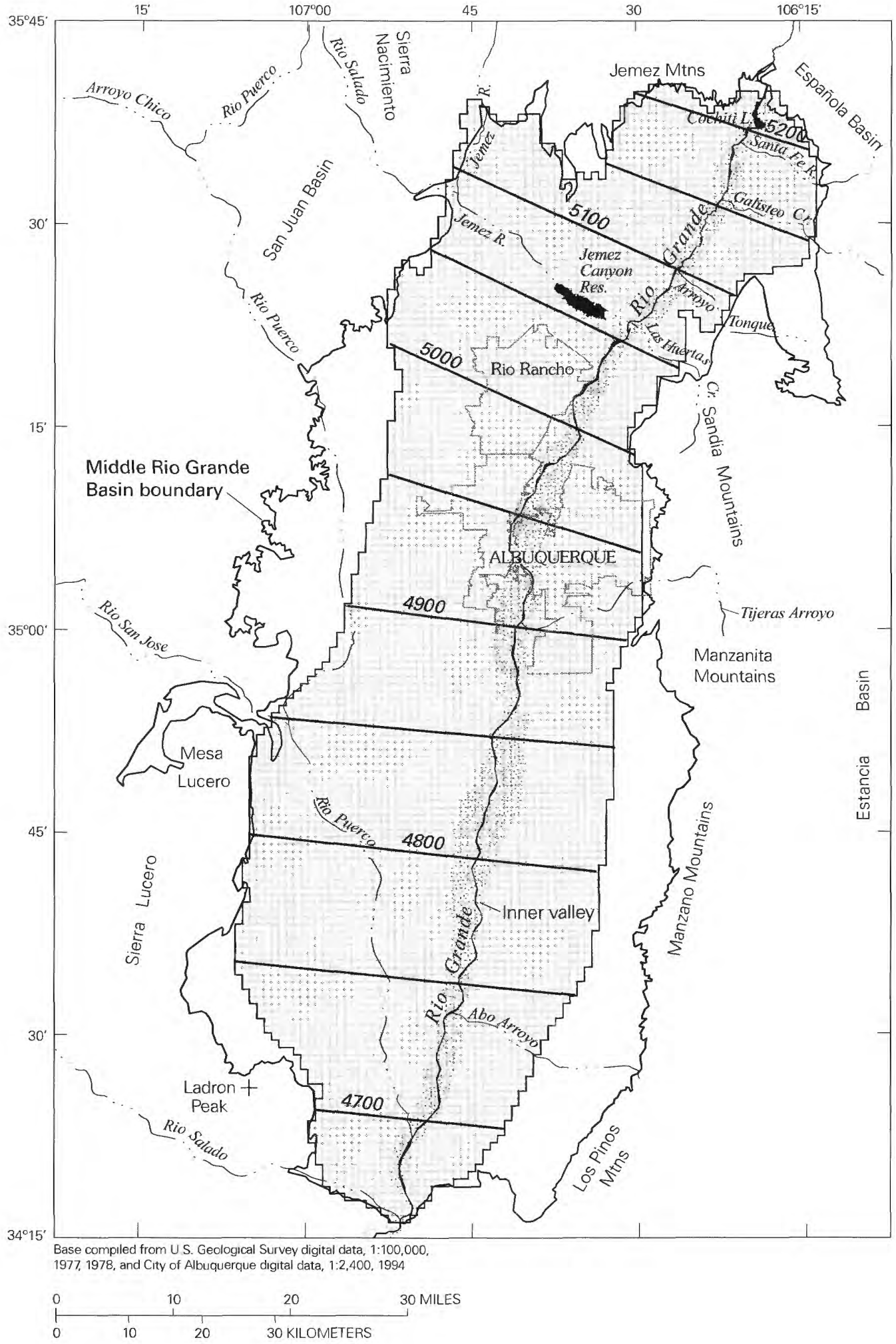

Figure 11. Altitude, in feet above sea level, of the base of model layer 1. 


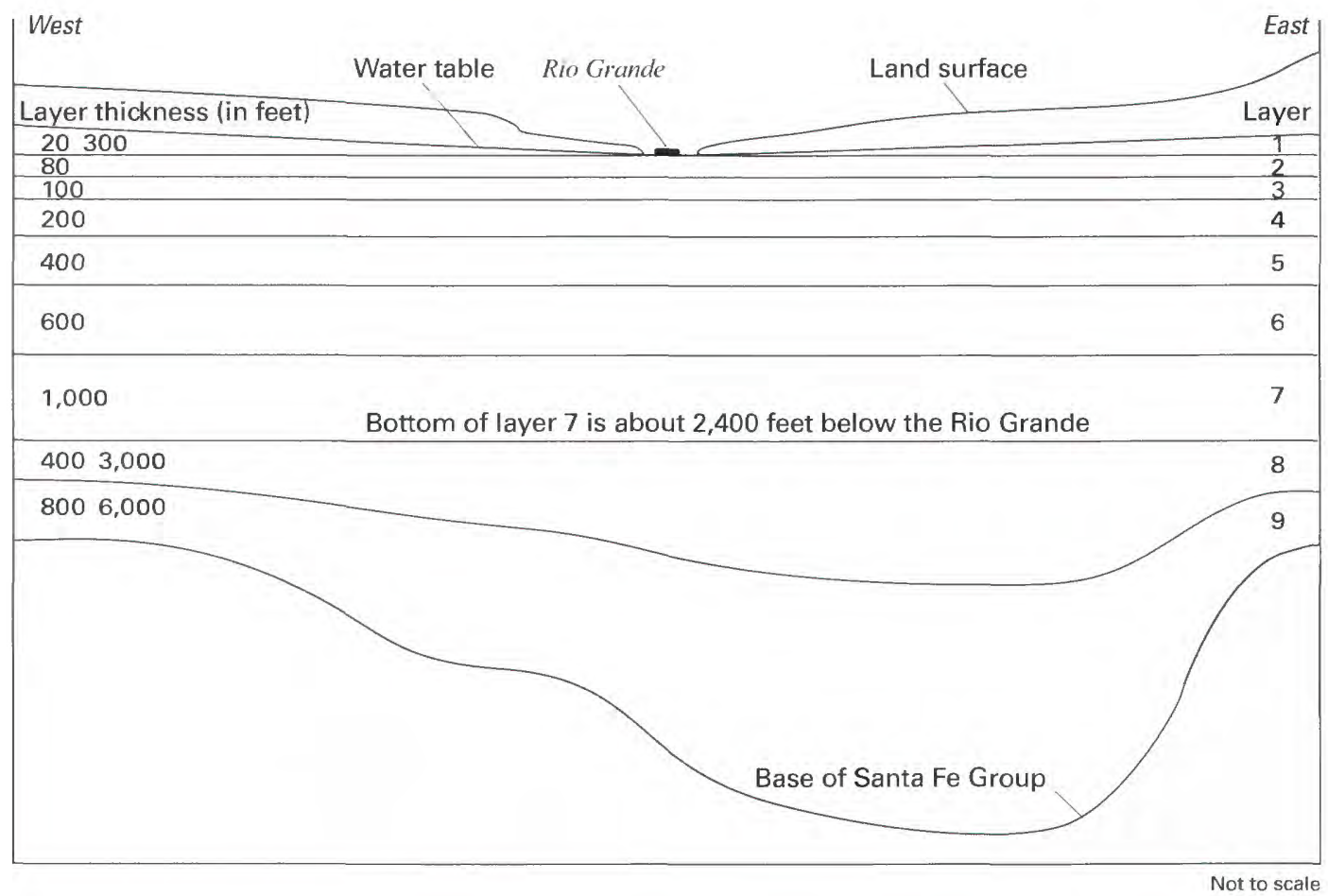

Figure 12. Configuration of model layers.
River and Rio Puerco to represent ground-water/surface-water interaction along those waterways. The manmade waterways and reservoirs within the basin were not included in this study because the simulations represent predevelopment conditions within the basin. The head-dependent boundary is simulated using the river package of MODFLOW (McDonald and Harbaugh, 1988). In the river package, flow between a surfacewater body and the underlying cell of the ground-water-flow model is a function of the altitude of the stage of the river; the simulated hydraulic head in the cell; the length and width of the river in the cell; and the altitude, vertical hydraulic conductivity, and thickness of the riverbed. The river dimensions, hydraulic conductivity, and thickness are combined into a single parameter referred to as the riverbed conductance. A separate riverbed conductance was estimated for the central Rio Grande, the Jemez River, the northern Rio Puerco, and the southern Rio Puerco. The northern and southern Rio Grande riverbed conductances were assigned large arbitrary values, because the inverse procedure indicated they should be high. but the procedure also indicated that the simulation results were very insensitive to their exact values.

The cells specified using the river package in this study included all of the regions within the flood plains of the Rio Grande, Jemez River, and Rio Puerco (fig. 13). This approach was used instead of treating the evapotranspiration (ET) boundary condition and Rio Grande boundary condition in these regions separately, as was done in the previous models. There were two main reasons for using this approach. The first reason for adopting this method was that rivers migrate across their flood plains over the course of several thousand years. This effect needed to be accounted for in the paleohydrologic simulation and in the steady-state, predevelopment simulation where the goal was to represent long-term average hydrologic conditions. This was especially critical because of the traveltime calculations made for wells near the flood plains. For a well immediately adjacent to a flood plain, the simulated distance from the well to the exact recharge cell within the valley may vary greatly depending on which side of the flood plain that reach of the river was on at the time the water was recharged. If the water is more than several decades old, this position cannot be determined. For this reason, the river fluxes were spread across the entire flood plain by assigning river cells across the entire flood plain. The second reason was that in this study the objective did not include distinguishing between the river and ET fluxes in the hydrologic budget of the basin. Including ET in a simulation affects mostly the calibrated position of the local water table and the distribution of the local ground-water to surface-water fluxes. For a flood plain with low relief, excluding ET has little effect on the total flux between the basin and the inner valley and river system.

\section{Specified-Inflow Boundary Conditions}

Recharge of precipitation and stream water is simulated as a specified flux to the uppermost active cell of the model, using the recharge package of MODFLOW. This recharge is divided into geographic zones, each of which generally corresponds to a basin-boundary segment, a group of basin-boundary segments, or a small stream or arroyo that is known to carry a significant volume of water at various times. There were nine major zones specified, and the zone along the Sandia Mountains was later divided into four 


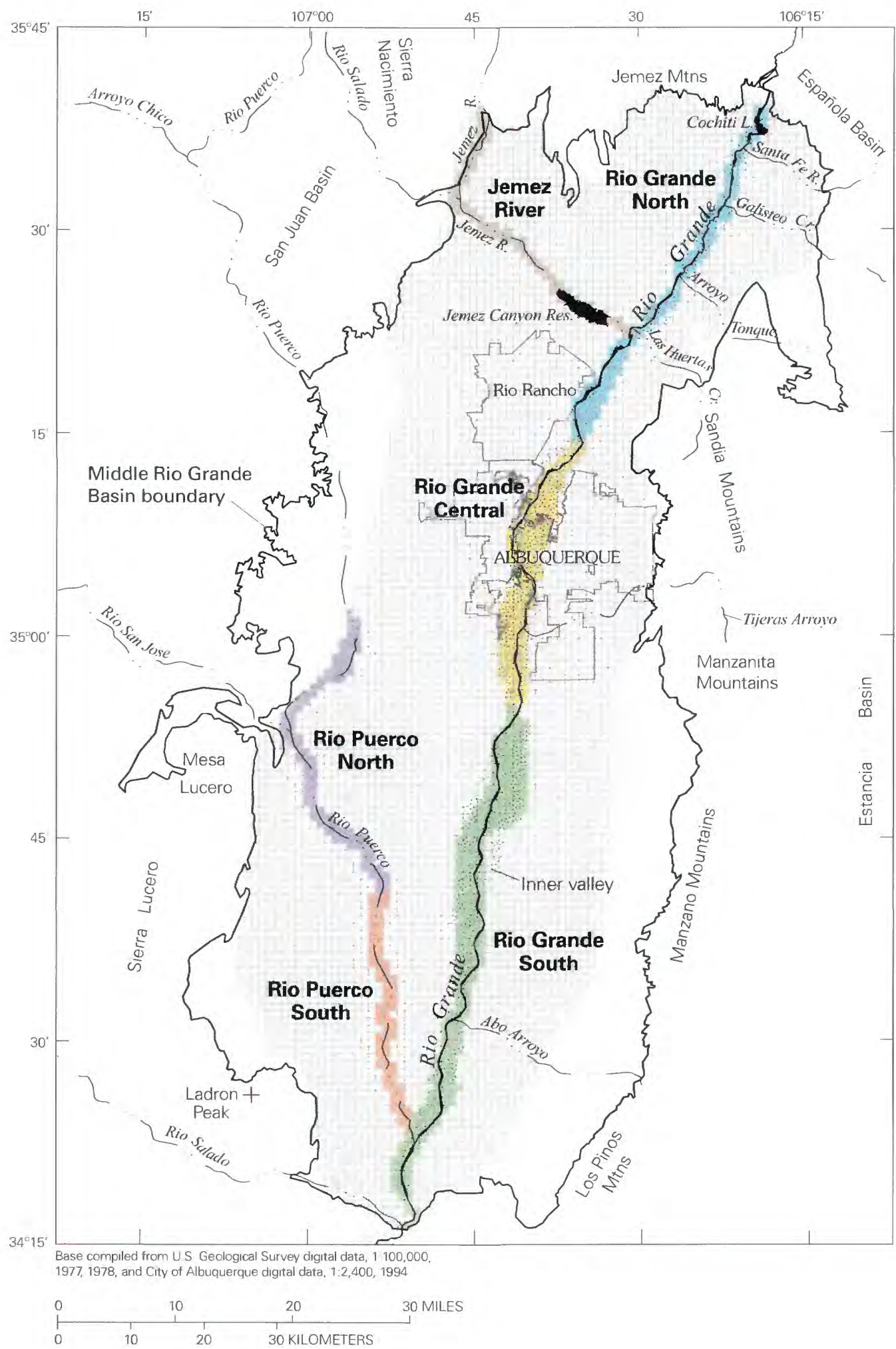

Figure 13. Location of head-dependent river cells in the ground-water-flow model. 
zones, giving 12 recharge zones in all (fig. 14). These 12 zones are: (1) mountain-front recharge along the Jemez Mountains; (2) tributary recharge along the Santa Fe River, Galisteo Creek, and Las Huertas Creek; (3) mountain-front recharge at the northern end of the Sandia Mountains; (4) mountain-front recharge at the north-central section of the Sandia Mountains; (5) mountain-front recharge at the south-central section of the Sandia Mountains; (6) mountain-front recharge at the southern end of the Sandia Mountains; (7) tributary recharge along Tijeras Arroyo; (8) mountain-front recharge along the Manzano Mountains; (9) tributary recharge along Abo Arroyo, (10) mountain-front recharge along the Los Pinos Mountains; (11) tributary recharge along the Rio Salado; and (12) mountain-front recharge along Ladron Peak. No recharge is specified across the top surface of the model, because the amount of rainfall during the year is exceeded by the amount of evaporation. Eventually mountain-front recharge along the Jemez Mountains was set to zero because as the inverse model estimated low values and could not distinguish between it and underflow at the same location. Some of the final estimate for the underflow there could also include mountain-front recharge.

Underflow along the basin boundaries is simulated using the well package of MODFLOW as a specified flow into layers 2, 3 and 4 of the model. The depth distribution of ground-water flow across the MRGB boundaries is uncertain. Underflow was specified in layers 5-9 in Kernodle and others (1995), in layer 3 in Tiedeman and others (1998), and in layers 1-3 in McAda and Barroll (2002). The current model specifies these fluxes at similar average depths to those in the previous models, and the influx is spread out vertically so that travel times to wells near those borders would not reflect an arbitrary influx in one layer only. The influx for layers 2, 3, and 4 was allocated in proportion to their thickness to maintain a consistent horizontal velocity throughout the vertical thickness of the inflow zone. The seven underflow zones (fig. 15) are: (1) along the Sierra Lucero Uplift, (2) along the Sand Hill Fault Zone, (3) along the boundary with the San Juan Basin, (4) along the western part of the Jemez Mountains, (5) along the eastern part of the Jemez Mountains, (6) along the boundary with the Espanola Basin, and (7) along the boundary with the Hagan Embayment.

\section{Hydraulic Properties}

The ground-water-flow model requires values of horizontal and vertical hydraulic conductivity to be specified throughout the domain. The degree to which these values vary across the basin is accounted for in the model by specifying hydraulic conductivity zones, with a single value of horizontal and/or vertical hydraulic conductivity associated with each zone. To create a more realistic and accurate model, the zone boundaries should follow the boundaries between the geologic formations or facies (Hill, 1998). In this study, a three-dimensional geologic model was used to create the pattern of hydraulic conductivity zones in the model.

\section{Geologic Model}

The geologic framework for the ground-water-flow model is based on a revised geologic model (Cole, 2001b) that was in turn based on detailed geologic mapping that had been conducted by the USGS, the New Mexico Bureau of Geology and Mineral Resources, and the University of New Mexico. Considerable insight to the three-dimensional distribution of geologic units within the model was made possible by recent geophysical investigations (Grauch and others, 2001; Rodriguez and others, 2001) and reinterpretations of existing data. The revised geologic model was also based on stratigraphic and lithologic interpretations of the sediments penetrated by numerous wells in the basin. In particular, careful consideration was given to the stratigraphic interpretations of Lozinsky $(1988,1994)$ for 12 deep oil-exploration wells from the central and southern parts of the system, and to interpretations from dozens of water wells in the central part of the system around Albuquerque and Rio Rancho (Hawley and Haase, 1992; Hawley and others, 1995; Connell and others, 1998). An independent interpretation of drill-hole geophysical logs was performed for many of the wells, using an empirical semiquantitative method to identify dominant grain-size characteristics of rift-fill sediments (Cole, 200lb). The goal of creating the geologic model was to define regional-scale hydrostratigraphic units that could be delimited in the subsurface across the structural subbasins from drill-hole data and geophysical constraints, where available. However, such data and constraints were lacking for major parts of the geologic model, such that the delimitation of hydrostratigraphic units was based on a conceptual understanding of overall rift history and the expected relationships between tectonic deformation and sedimentation (Stone, 2001; Stone and others, 2001).

The higher density of pre-rift sediments allowed the regional gravity data (Grauch and others, 2001) to be used to calculate the bottom of the aquifer system. This procedure dramatically revealed the important substructure of the Middle Rio Grande "Basin," which consists of discrete deep subbasins in the northern and central areas and a highly irregular subbasin complex in the south (fig. 16). This irregular surface was specified as the bottom of the aquifer system, and it was used to define the bottom of the ground-water-flow model (fig. 17).

Faults are important structural and hydrologic elements in the aquifer framework, and several sources of data were used to identify the principal fault zones in the basins. Sharp gradient zones in the gravity data indicate boundaries of major blocks of basement-density material, and these zones largely coincide with north- and northwest-trending margins of the deeper (older) parts of the structural subbasins. Younger faults that are manifest in the near surface chiefly trend north-south (fig. 3) and reflect the dominant extension direction during the last 5 million years. A final set of fault trends for the geologic model of the basin was determined by comparing independent compilations based on aeromagnetic lineament data (Grauch and others, 2001), topographic scarps defined by digital elevation data, mapped fault zones (Hudson and others, 1999), and fault scarps known or inferred to reflect Quaternary offset 


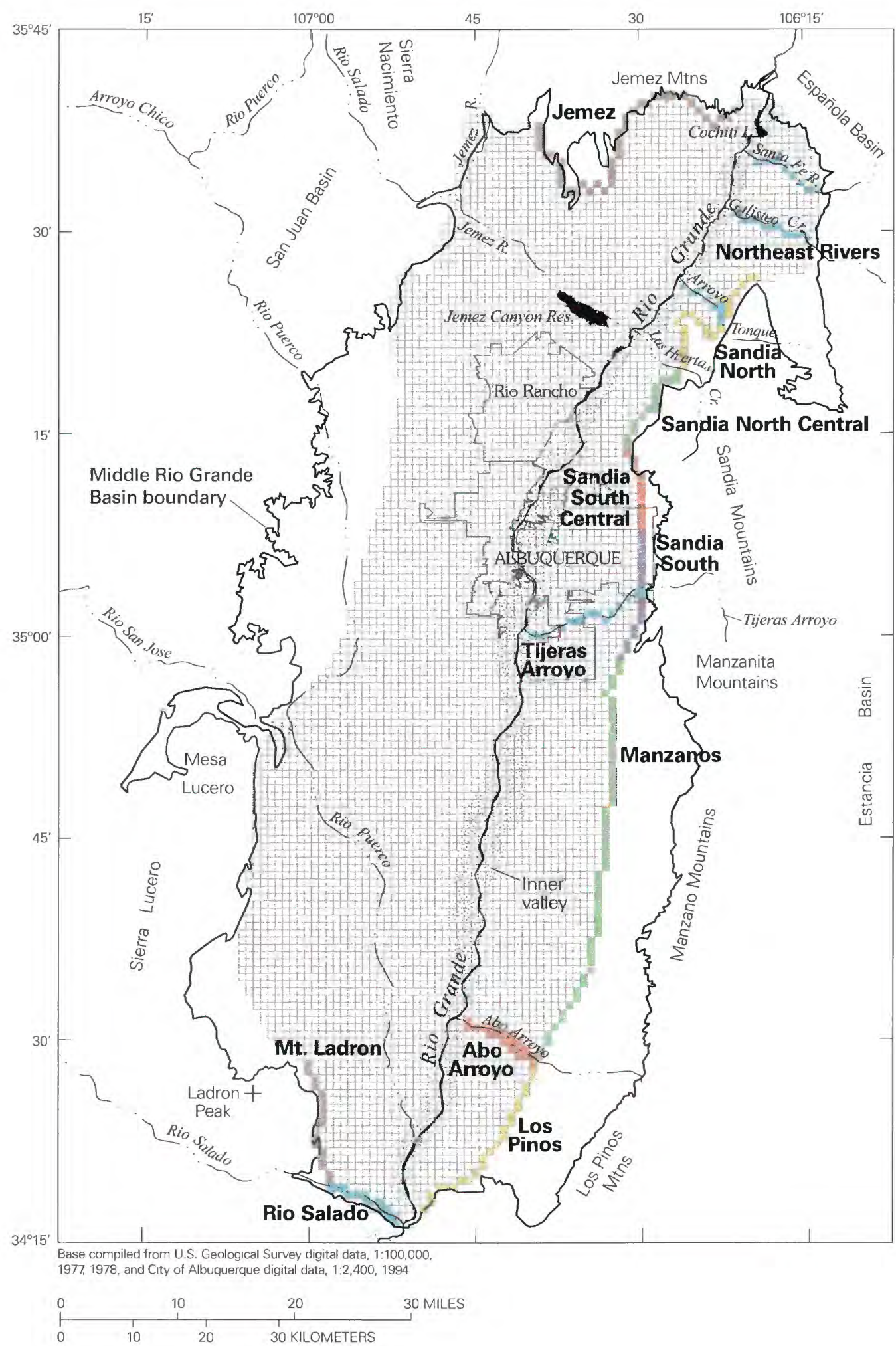

Figure 14. Location of mountain-front and arroyo recharge cells in the ground-water-flow model. 


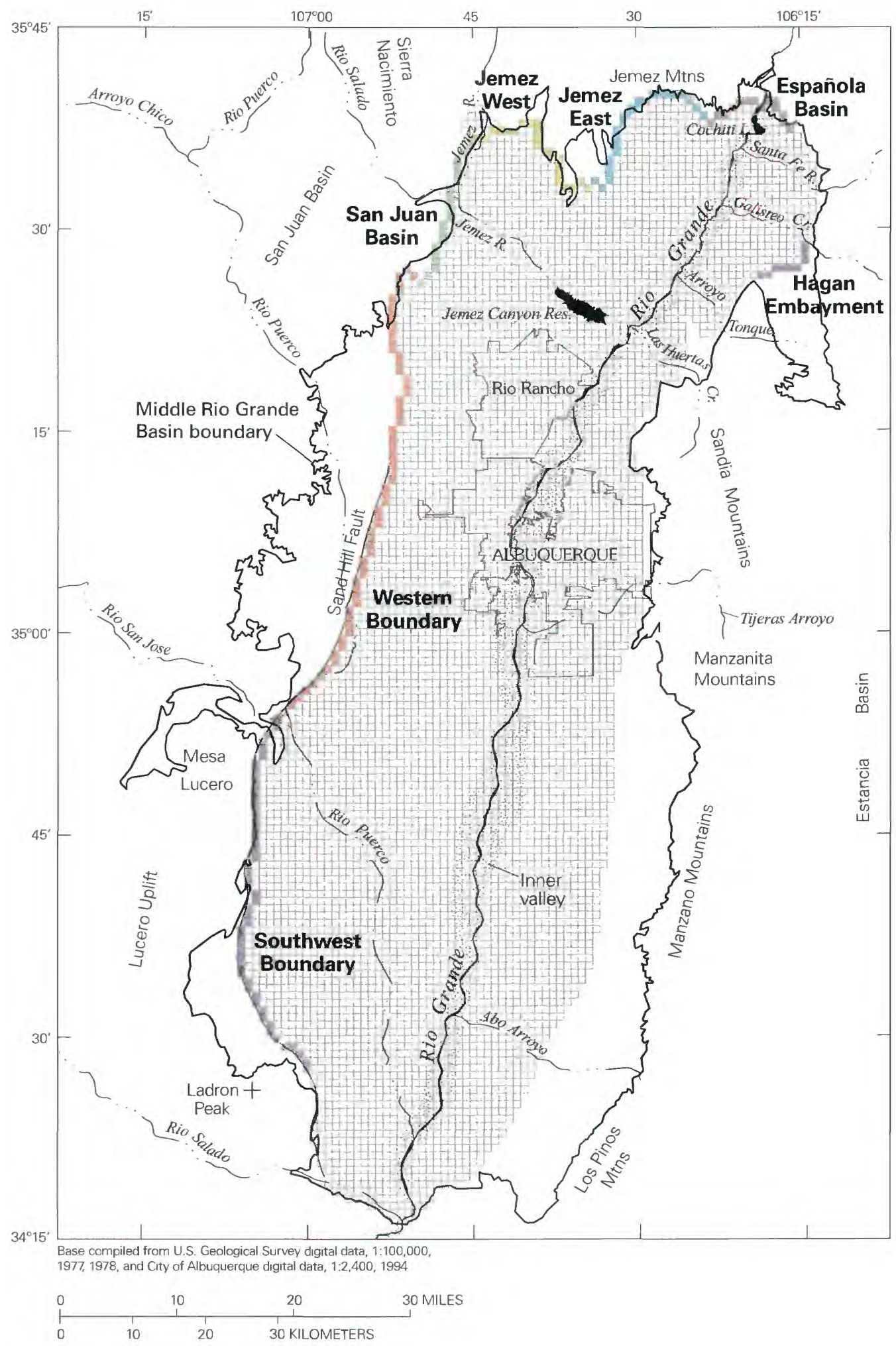

Figure 15. Location of specified underflow cells in the ground-water-flow model. 

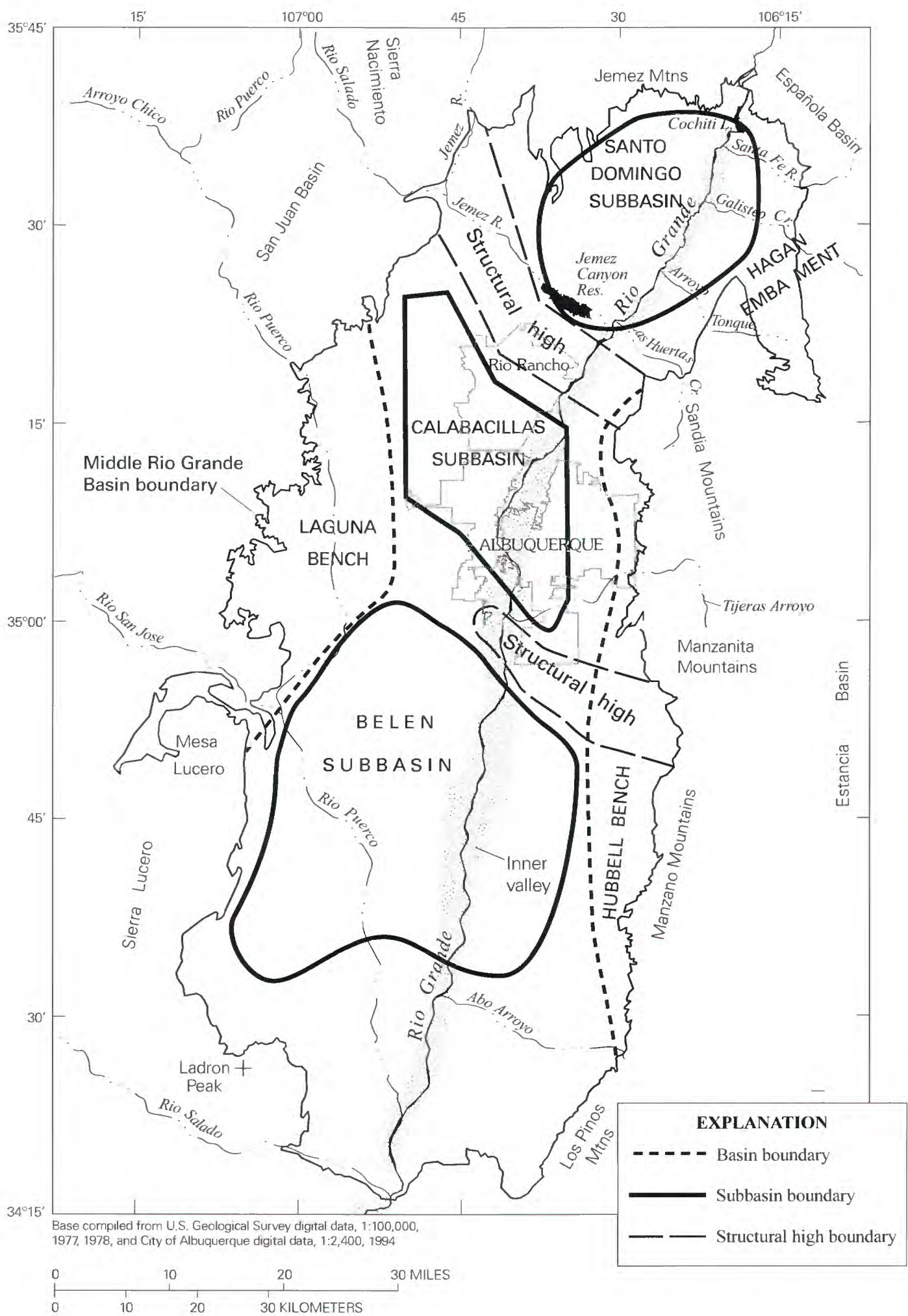

Figure 16. Simplified structure of the Albuquerque Basin, showing subbasins identified from gravity data in Grauch and others (2001). 


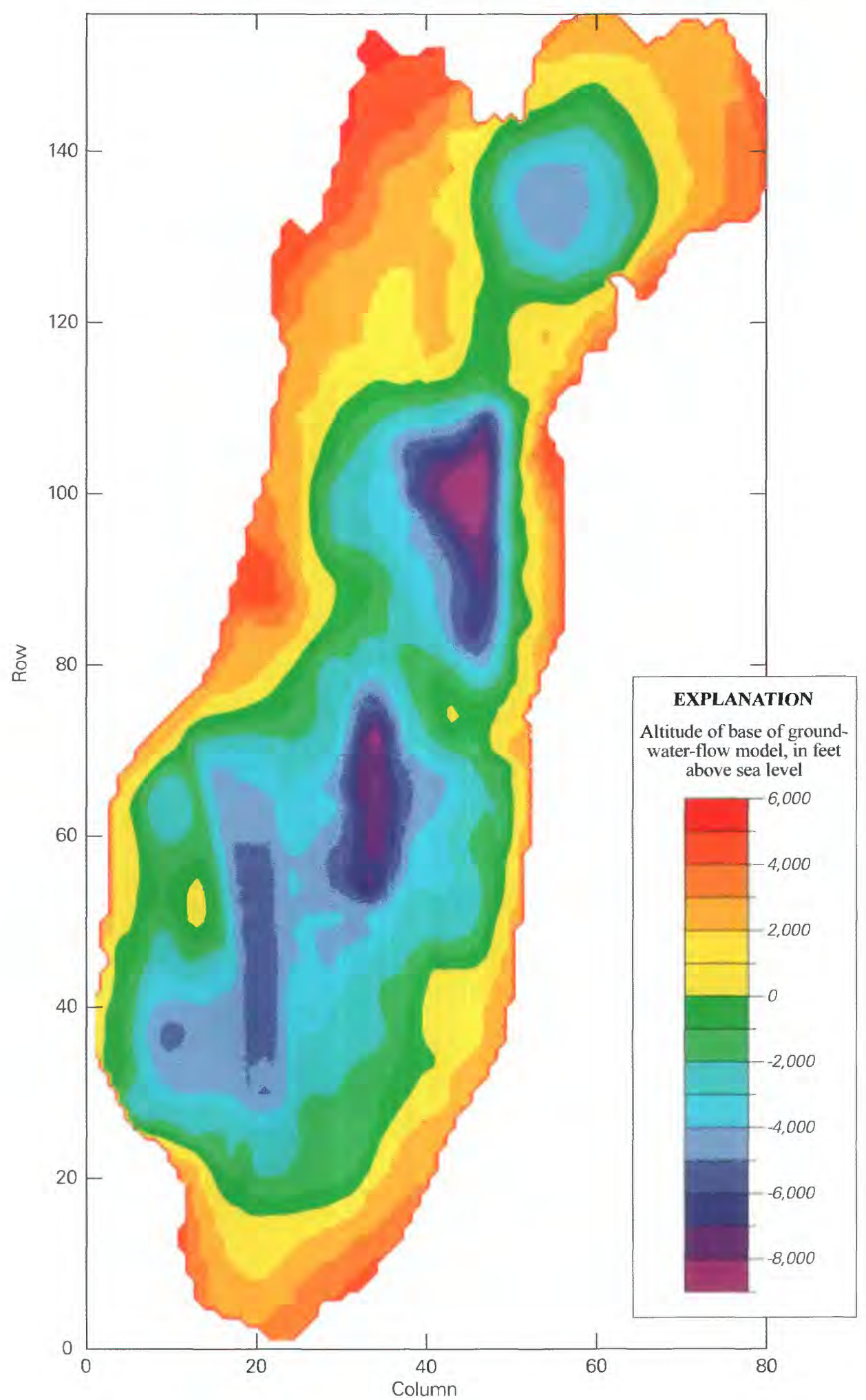

Figure 11. Altitude of the base of the ground-water-flow model. Surface is based on geophysical data in Cole and others (2001) and Grauch and others (2001). 
(Machette and others, 1998). Of all the faults in the geologic model, only two were treated explicitly in the model in this study - the Cat Mesa Fault Zone and the Sandia Fault Zone. These were the only two zones across which large discontinuities in water levels could be observed in the model region.

The hydrostratigraphic units distributed through the three-dimensional geologic model were necessarily simple and coarsely defined, as required for the regional scale of the model. Nonetheless, they were consistently defined on the basis of overall grain size and bedding characteristics that reflect the conceptual sedimentological controls on deposition during rift-basin subsidence (Stone, 2001; Stone and others, 2001). The lowest units in the northern and southern subbasins are dominantly volcaniclastic sand and gravel reflecting erosion of volcanic-source terranes outside the rift basin; the oldest unit in the central subbasin is chiefly eolian sand and playa silt and clay. The thick and variable middle section of all three subbasins is composed of fluvial sand and silt derived from various external sources and accumulated in depositional centers through much of Miocene time while faulting was quite active and climate was temperate. The uppermost blanketing unit in all three subbasins consists of coarse gravel and sand that reflects a regional change to wetter climate at about $5 \mathrm{Ma}$ (Raymo and Ruddiman, 1992). Sometime after $2.7 \mathrm{Ma}$ (Kelley and Kudo, 1978), the ancestral Rio Grande drainage was integrated through and downstream of this region and the river system began to incise the existing basin fill (Cole, 2001b).

\section{Hydraulic Conductivity Zones}

The hydraulic conductivity zones of the ground-waterflow model were based directly on the hydrostratigraphy as represented in the three-dimensional geologic model (Cole, 2001b). The geologic model of the MRGB was constructed from the geologic data described above using Earth Vision geologic modeling software by Dynamic Graphics, Inc. Gridded data points were exported from the Earth Vision model listing the elevation of the top of each hydrostratigraphic unit at the UTM grid locations of cell boundaries in the MODFLOW ground-water-flow model (McAda and others, 2001). Similarly, gridded data were exported from the geologic model that defined the location and extent of each of the major faults in the model. In this fashion, the Earth Vision geology model was converted into input for the MODFLOW model with little distortion or loss of detail (figs. 18-27).

A total of 12 hydrostratigraphic units from the geologic model were converted to 18 hydraulic conductivity zones within the ground-water-flow model. Most of the zone refinement was based on the sensitivity of the model results to the different hydrostratigraphic zones. Where sensitivity was high. hydrostratigraphic zones were subdivided further into geographic subzones. In this way, the medium-to-coarse-sand unit that covers a large section of the basin was subdivided into six geographic subzones. Likewise the medium-sand unit and the proximal-volcanic-sand unit were subdivided into northern and southern subzones. Where sensitivity of the model results was low, hydrostratigraphic zones were combined. In this way extrusive and intrusive volcanics were combined, and the fine and very fine (eolian) sand were combined. In the case of the river alluvium, a recombination was made of the ancient and modern alluvium geologic zones into northern, central, and southern alluvium zones.

Vertical conductances in the ground-water-flow model were divided into 12 zones as values of vertical anisotropy. Each of the three Rio Grande alluvium zones was assigned a separate anisotropy; six of the medium-to-coarse sand-unit zones were each assigned an anisotropy value; the remaining three anisotropy values were assigned to the remaining units in the basin as northern, central, and southern values. The boundaries between these final three zones correspond roughly to the boundaries between the different subbasins (fig. 16). The north-south-trending faults within the basin (fig. 18) suggest there may be a regional north-south to east-west anisotropy in the basin. For this reason, a single value of north-south to eastwest anisotropy was assigned to the entire basin in the groundwater-flow model. Best-fit values of the vertical anisotropies and vertical and horizontal hydraulic conductivities were estimated during the model calibration.

\section{GROUND-WATER PATH LINE MODEL}

The main purpose of this study is to use environmental tracer data to help improve estimates of parameters used in ground-water-flow models of the MRGB. To achieve this, a predevelopment ground-water-flow model of the basin was calibrated using parameter estimation methods and the environmental tracer data collected by Plummer and others (2004). Ground-water ages obtained from ${ }^{14} \mathrm{C}$ activities are one set of these data. When these observed ages are compared with equivalent simulated ages, the residuals can be used to directly influence the model calibration. The simulated ages are obtained by using MODPATH (Pollock, 1994) to track the line of travel of a parcel of water from an observation well backward to a recharge location. MODPATH is a post-processing program that is used in conjunction with the cell-by-cell flow rates calculated with MODFLOW. Time of travel can be integrated backward along a path line to obtain a simulated ground-water age. Another source of tracer information that is useful for calibration is the identification of the hydrochemical zones (fig. 9). These zones identify waters with different source areas. A delineation of waters with different source areas can also be simulated using MODPATH. A map of the distribution of ground water originating from different sources can be constructed by tracking a parcel of water backward from every cell in the model, and then plotting a symbol for the source areas at the cell centers. Such a simulated map can be compared with the hydrochemical zone map to help calibrate the model.

\section{Porosity}

The calculation of ground-water age by backward path line tracking requires the calculation of the seepage velocity at each cell face. Whereas the ground-water-flow model can 


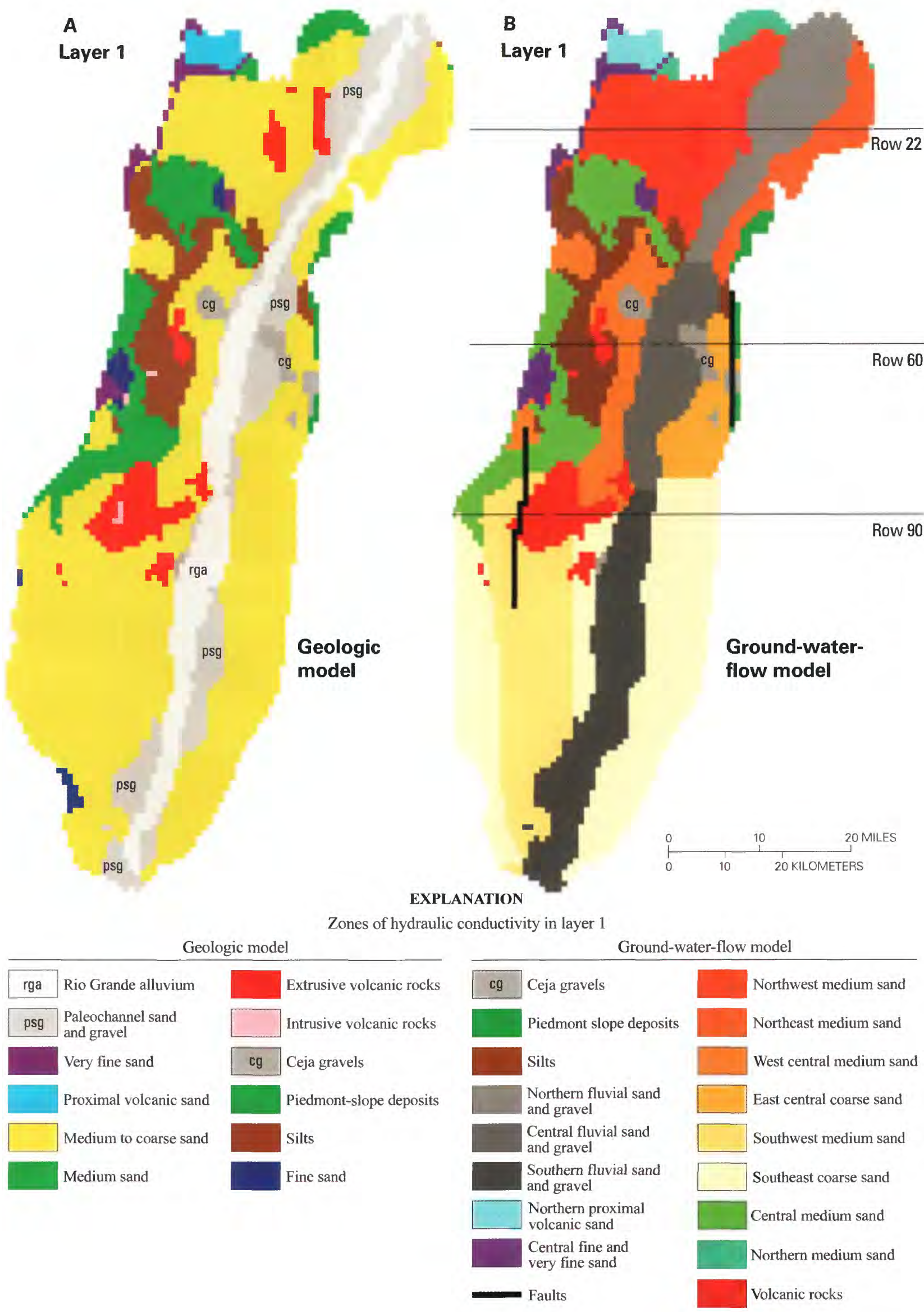

Figure 18. Hydraulic conductivity zones of layer 1 as defined in (A) the geologic model of Cole (2000b), and (B) the ground-water-flow model. 


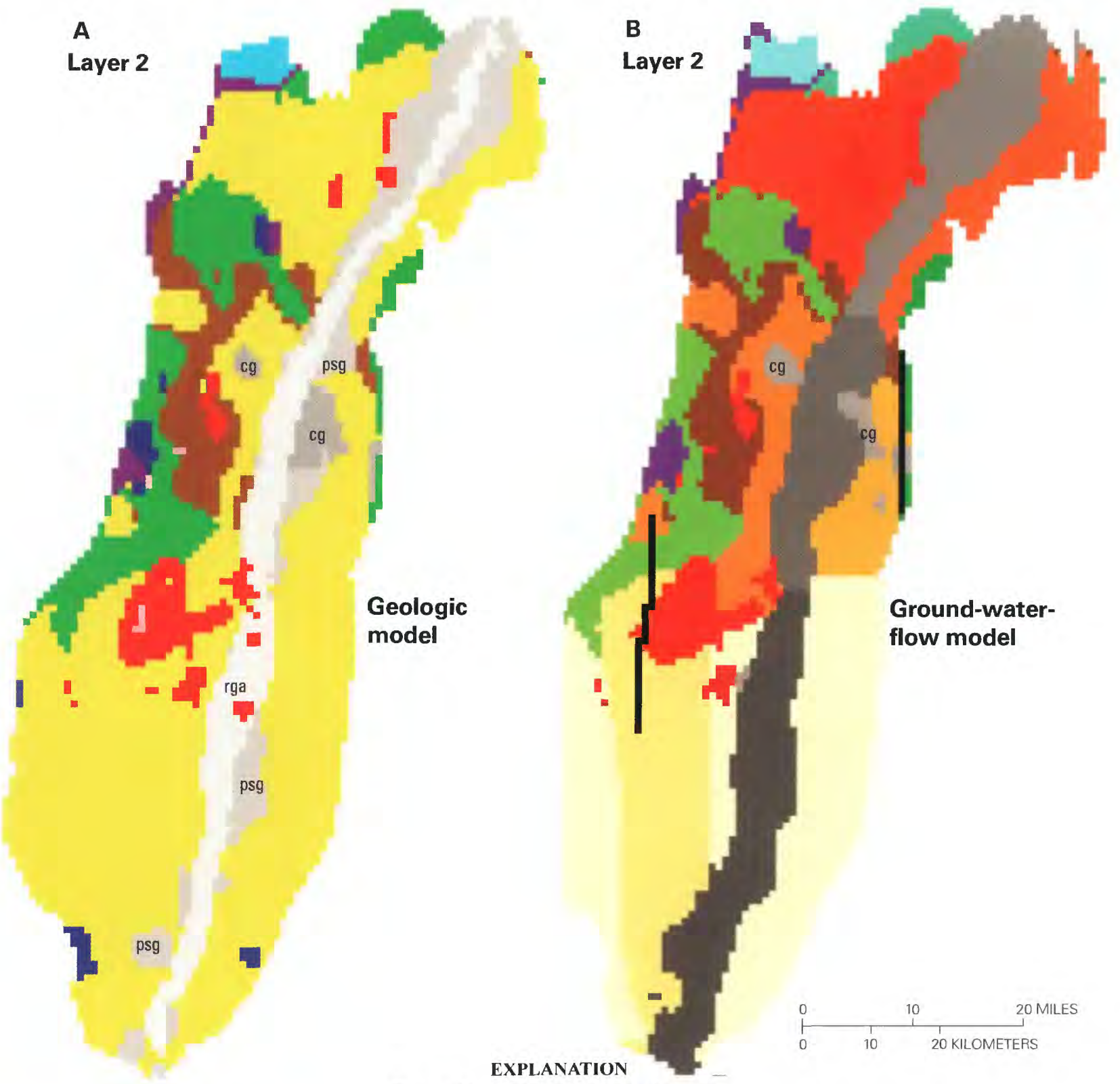

Zones of hydraulic conductivity in layer 1

Geologic model

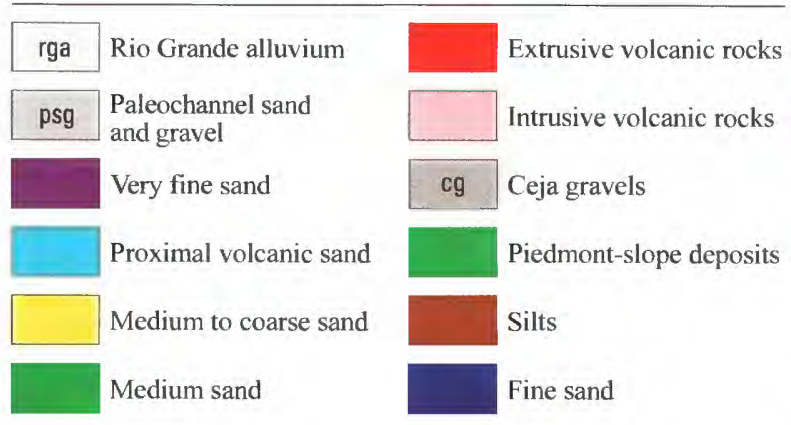

Ground-water-flow model

\begin{tabular}{|c|c|c|}
\hline $\operatorname{cg}$ & Ceja gravels & Northwest medium sand \\
\hline & Piedmont slope deposits & Northeast medium sand \\
\hline & Silts & West central medium sand \\
\hline & $\begin{array}{l}\text { Northern fluvial sand } \\
\text { and gravel }\end{array}$ & East central coarse sand \\
\hline & $\begin{array}{l}\text { Central fluvial sand } \\
\text { and gravel }\end{array}$ & Southwest medium sand \\
\hline & $\begin{array}{l}\text { Southern fluvial sand } \\
\text { and gravel }\end{array}$ & Southeast coarse sand \\
\hline & $\begin{array}{l}\text { Northern proximal } \\
\text { volcanic sand }\end{array}$ & Central medium sand \\
\hline & $\begin{array}{l}\text { Central fine and } \\
\text { very fine sand }\end{array}$ & Northern medium sand \\
\hline & Faults & Volcanic rocks \\
\hline
\end{tabular}

Figure 19. Hydraulic conductivity zones of layer 2 as defined in (A) the geologic model of Cole (2000b), and (B) the ground-water-flow model. 


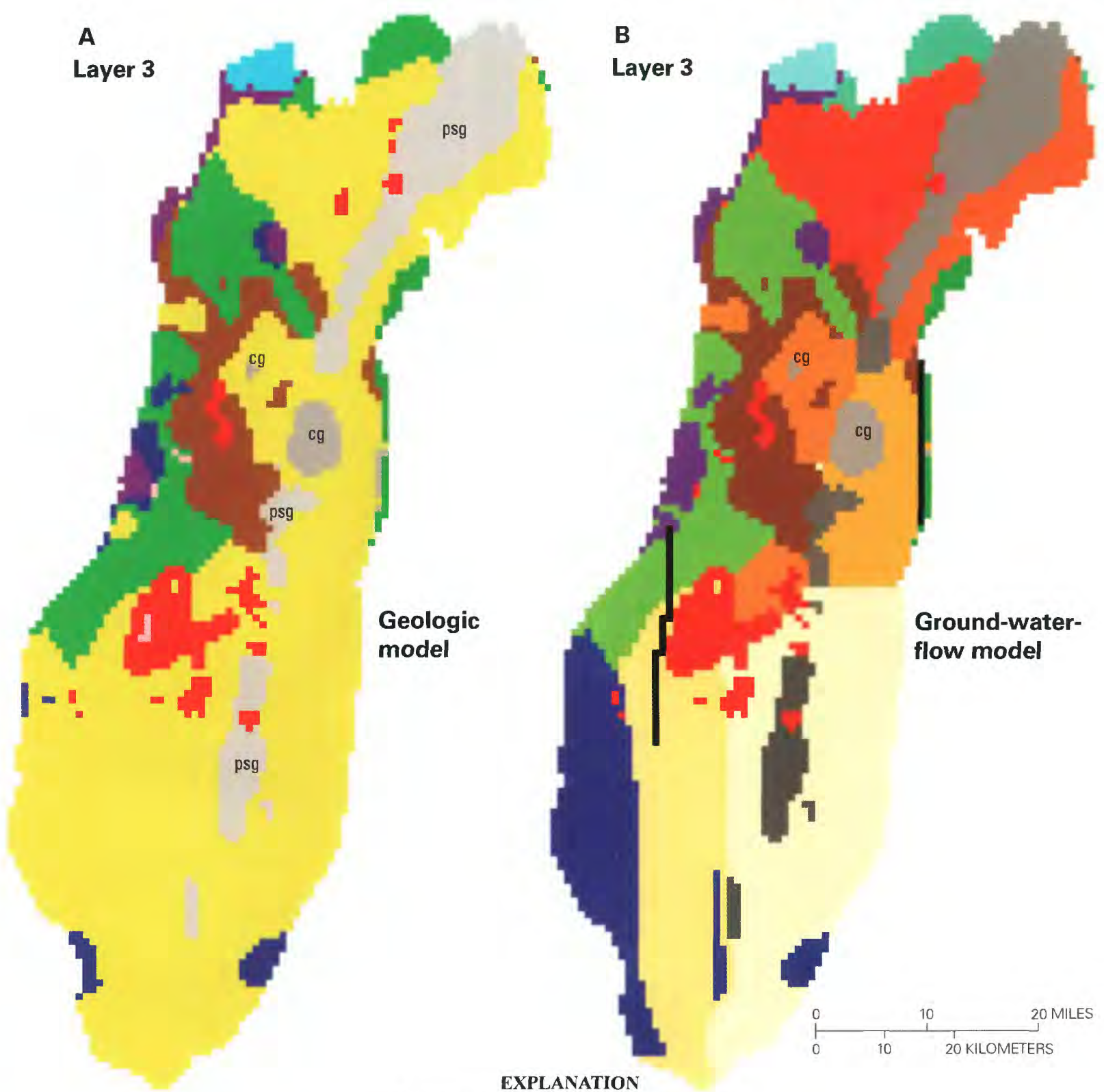

Zones of hydraulic conductivity in layer 3

Geologic model

\begin{tabular}{|c|c|c|c|}
\hline rga & Rio Grande alluvium & & Extrusive volcanic rocks \\
\hline psg & $\begin{array}{l}\text { Paleochannel sand } \\
\text { and gravel }\end{array}$ & & Intrusive volcanic rocks \\
\hline & Very fine sand & $\mathrm{cg}$ & Ceja gravels \\
\hline & Proximal volcanic sand & & Piedmont-slope deposits \\
\hline & Medium to coarse sand & & Silts \\
\hline & Medium sand & & Fine sand \\
\hline
\end{tabular}

\begin{tabular}{|c|c|c|}
\hline \multicolumn{3}{|c|}{ Ground-water-flow model } \\
\hline $\mathrm{cg}$ & Ceja gravels & Northwest medium sand \\
\hline & Piedmont slope deposits & Northeast medium sand \\
\hline & Silts & West central medium sand \\
\hline & Fine sand & East central coarse sand \\
\hline & $\begin{array}{l}\text { Northern fluvial sand } \\
\text { and gravel }\end{array}$ & Southwest medium sand \\
\hline & $\begin{array}{l}\text { Central fluvial sand } \\
\text { and gravel }\end{array}$ & Southeast coarse sand \\
\hline & $\begin{array}{l}\text { Southern fluvial sand } \\
\text { and gravel }\end{array}$ & Central medium sand \\
\hline & $\begin{array}{l}\text { Northern proximal } \\
\text { volcanic sand }\end{array}$ & Northern medium sand \\
\hline & $\begin{array}{l}\text { Central fine and } \\
\text { very fine sand }\end{array}$ & Volcanic rocks \\
\hline
\end{tabular}

Figure 20. Hydraulic conductivity zones of layer 3 as defined in (A) the geologic model of Cole (2000b), and (B) the ground-water-flow model. 


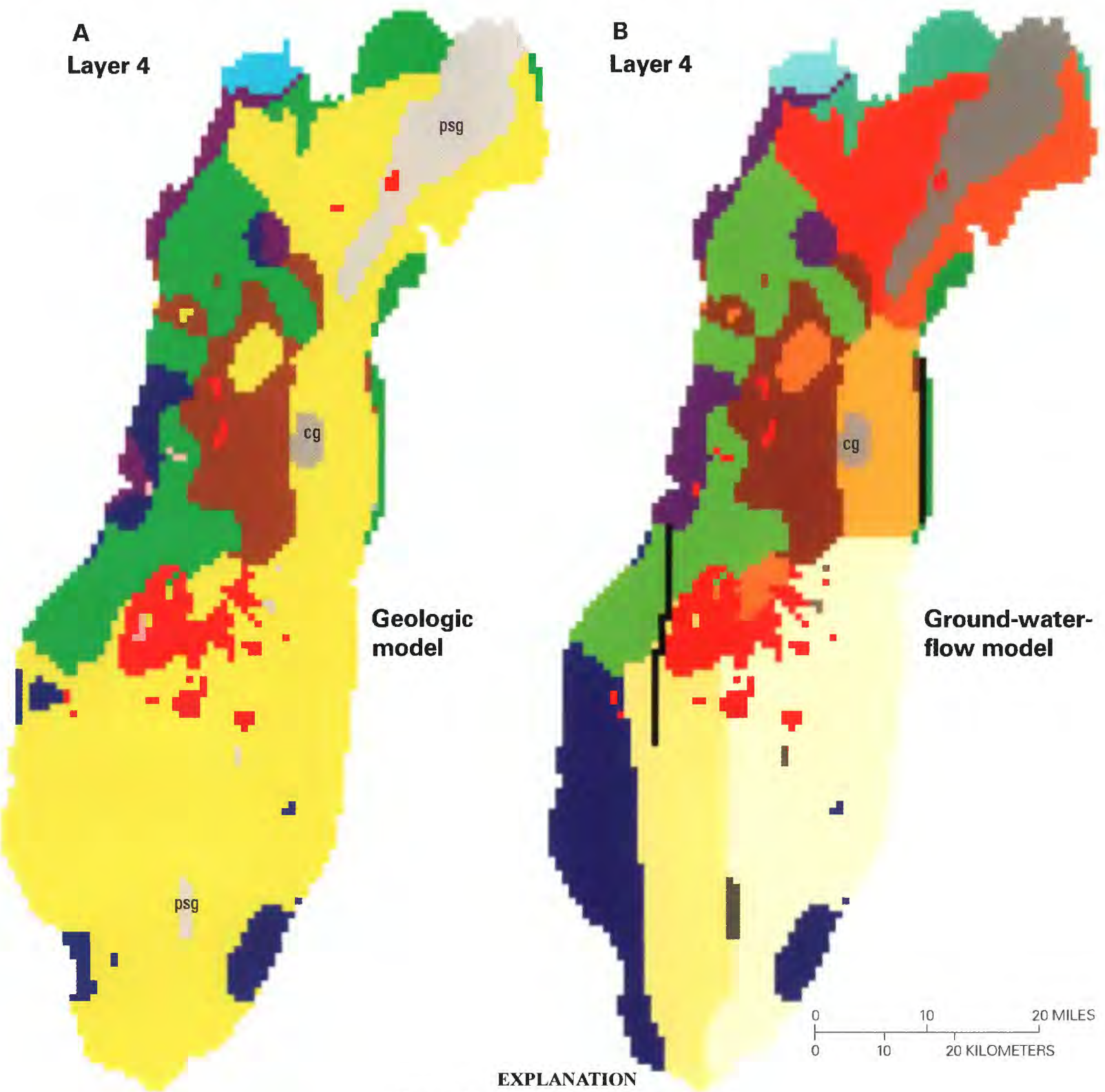

Zones of hydraulic conductivity in layer 4

\begin{tabular}{|c|c|c|c|}
\hline \multicolumn{4}{|c|}{ Geologic model } \\
\hline rga & Rio Grande alluvium & & Extrusive volcanic rocks \\
\hline $\mathrm{psg}$ & $\begin{array}{l}\text { Paleochannel sand } \\
\text { and gravel }\end{array}$ & & Intrusive volcanic rocks \\
\hline & Very fine sand & $\mathrm{cg}$ & Ceja gravels \\
\hline & Proximal volcanic sand & & Piedmont-slope deposits \\
\hline & Medium to coarse sand & & Silts \\
\hline & Medium sand & & Fine sand \\
\hline
\end{tabular}

\begin{tabular}{|c|c|c|}
\hline \multicolumn{3}{|c|}{ Ground-water-flow model } \\
\hline $\mathrm{cg}$ & Ceja gravels & Northwest medium sand \\
\hline & Piedmont slope deposits & Northeast medium sand \\
\hline & Silts & West central medium sand \\
\hline & Fine sand & East central coarse sand \\
\hline & $\begin{array}{l}\text { Northern fluvial sand } \\
\text { and gravel }\end{array}$ & Southwest medium sand \\
\hline & $\begin{array}{l}\text { Central fluvial sand } \\
\text { and gravel }\end{array}$ & Southeast coarse sand \\
\hline & $\begin{array}{l}\text { Southern fluvial sand } \\
\text { and gravel }\end{array}$ & Central medium sand \\
\hline & $\begin{array}{l}\text { Northern proximal } \\
\text { volcanic sand }\end{array}$ & Northern medium sand \\
\hline & $\begin{array}{l}\text { Central fine and } \\
\text { very fine sand }\end{array}$ & Volcanic rocks \\
\hline
\end{tabular}

Figure 21. Hydraulic conductivity zones of layer 4 as defined in (A) the geologic model of Cole (2000b), and (B) the ground-water-flow model. 


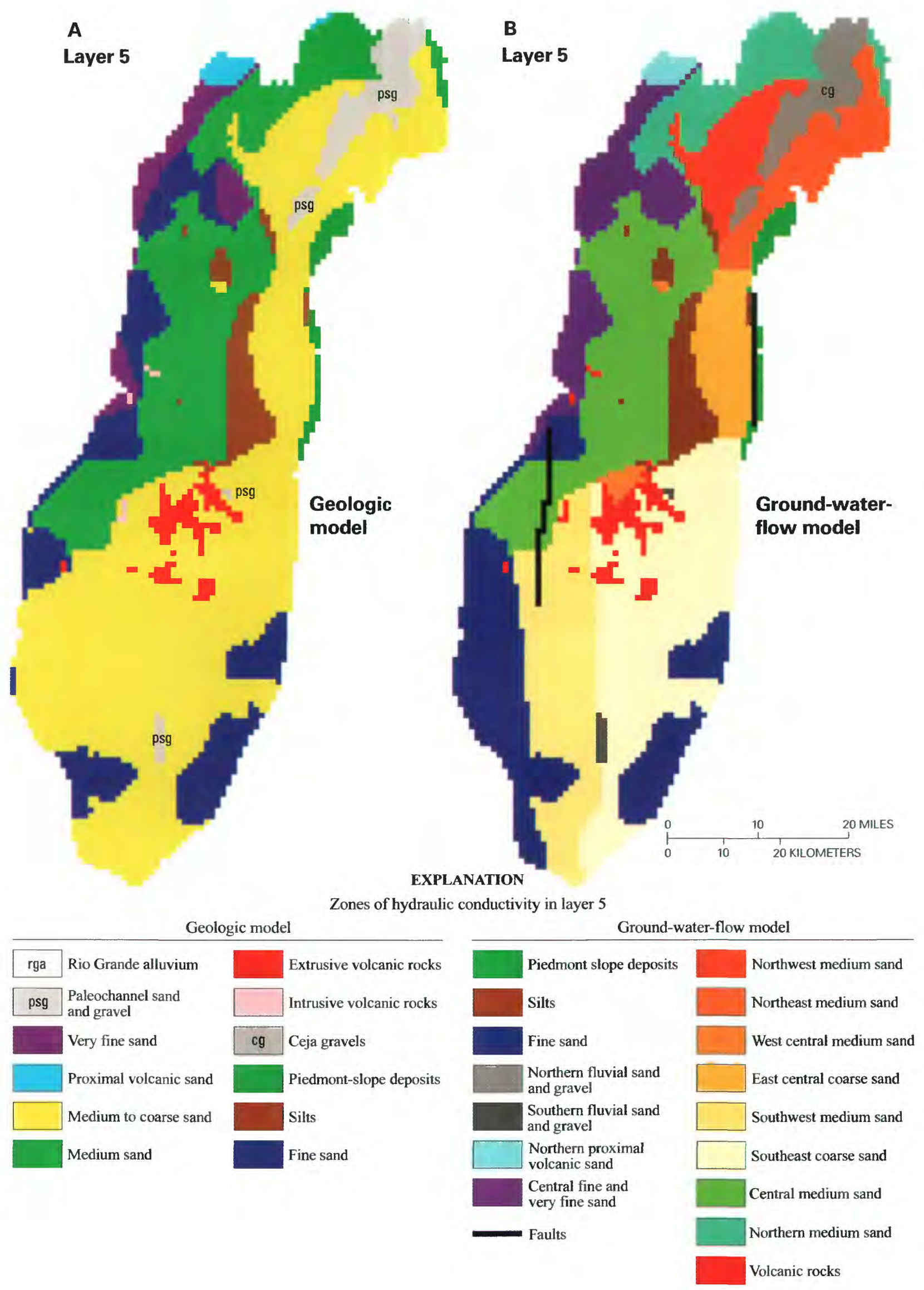

Figure 22. Hydraulic conductivity zones of layer 5 as defined in (A) the geologic model of Cole (2000b), and (B) the ground-water-flow model. 


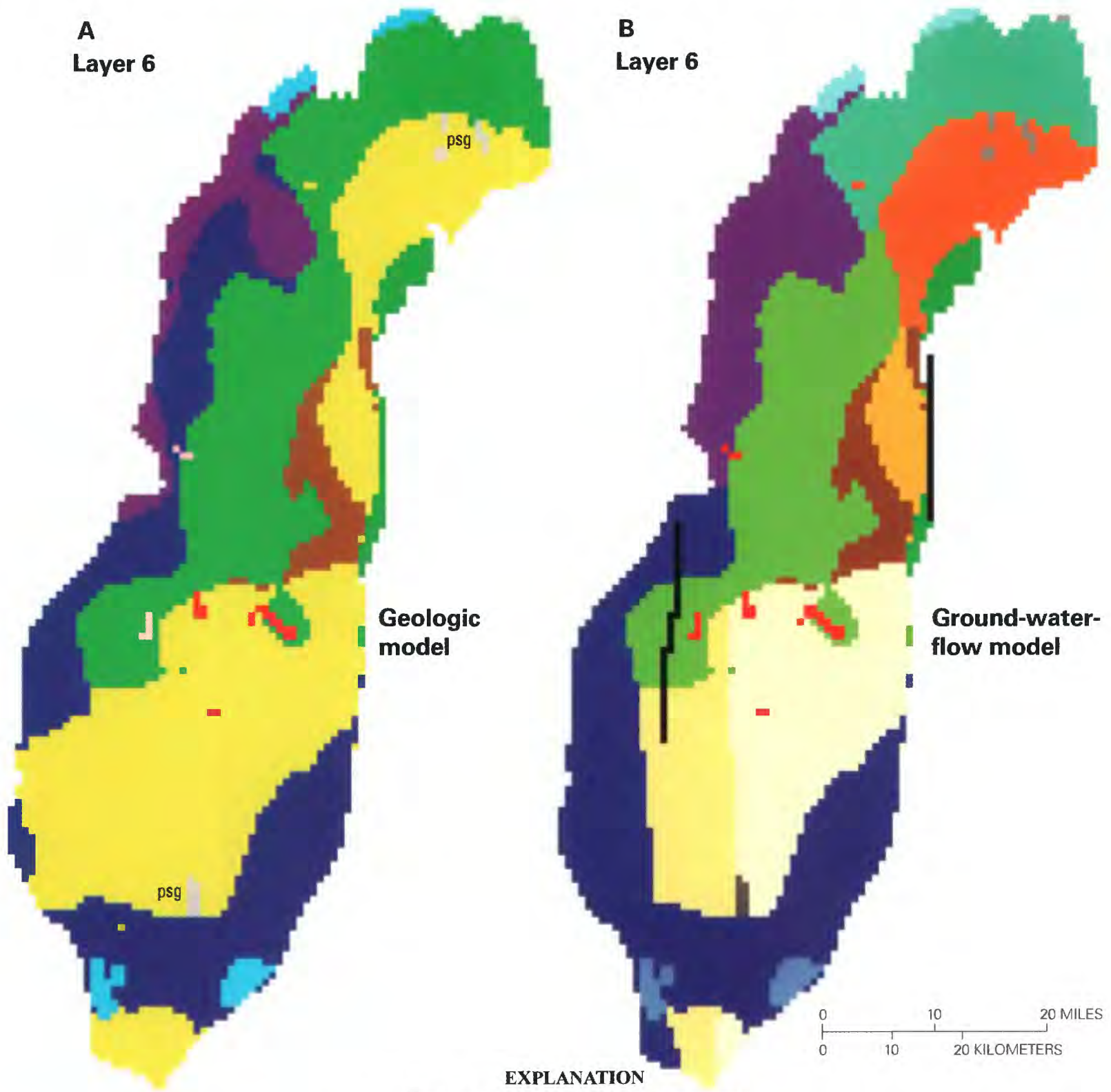

Zones of hydraulic conductivity in layer 6

Geologic model

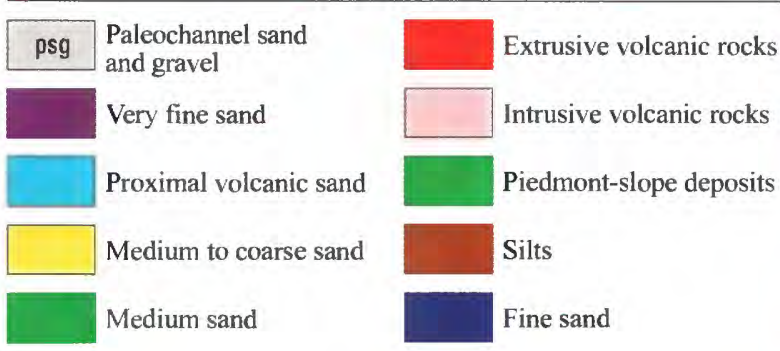

Ground-water-flow model

\begin{tabular}{|l|l|}
\hline Piedmont-slope deposits & Northwest medium sand \\
\hline Silts & Northeast medium sand \\
\hline $\begin{array}{l}\text { Northern fluvial sand } \\
\text { and gravel }\end{array}$ & South central coarse sand \\
\hline $\begin{array}{l}\text { Southern fluvial sand } \\
\text { and gravel }\end{array}$ & Southeast coarse sand \\
\hline $\begin{array}{l}\text { Northern proximal } \\
\text { volcanic sand }\end{array}$ & Central medium sand \\
\hline $\begin{array}{l}\text { Central fine and } \\
\text { very fine sand }\end{array}$ & Northern medium sand \\
\hline $\begin{array}{l}\text { Southern proximal } \\
\text { volcanic sand }\end{array}$ & Volcanic rocks \\
\hline \begin{tabular}{l} 
Faults \\
\hline
\end{tabular} & Saltium sand \\
\hline
\end{tabular}

Figure 23. Hydraulic conductivity zones of layer 6 as defined in (A) the geologic model of Cole (2000b), and (B) the ground-water-flow model. 


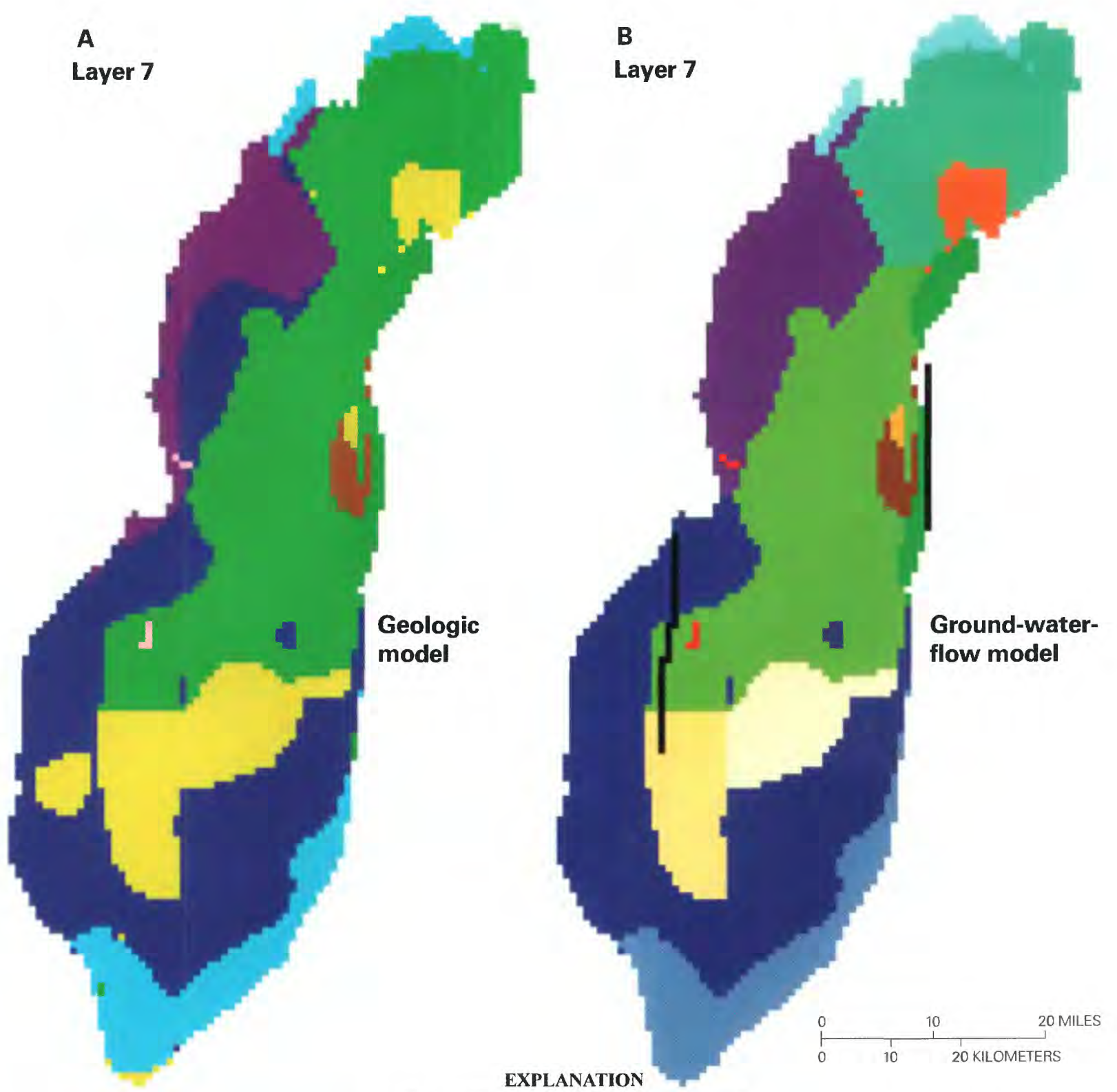

Zones of hydraulic conductivity in layer 7

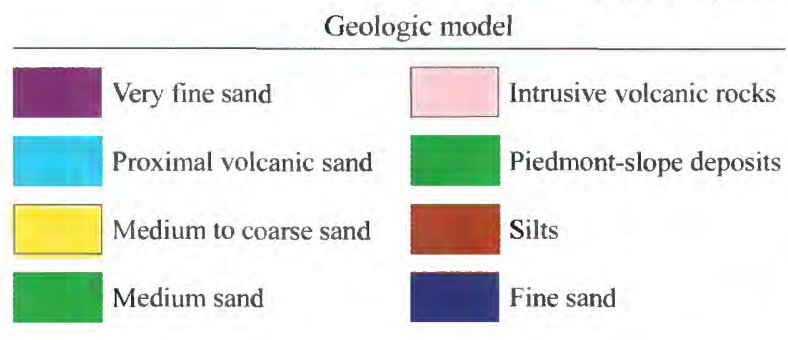

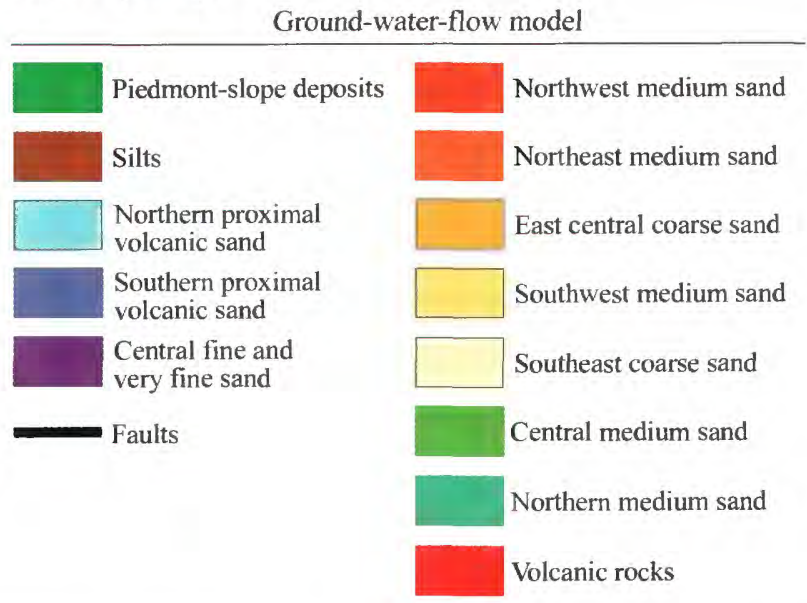

Figure 24. Hydraulic conductivity zones of layer 7 as defined in (A) the geologic model of Cole (2000b), and (B) the ground-water-flow model. 
A

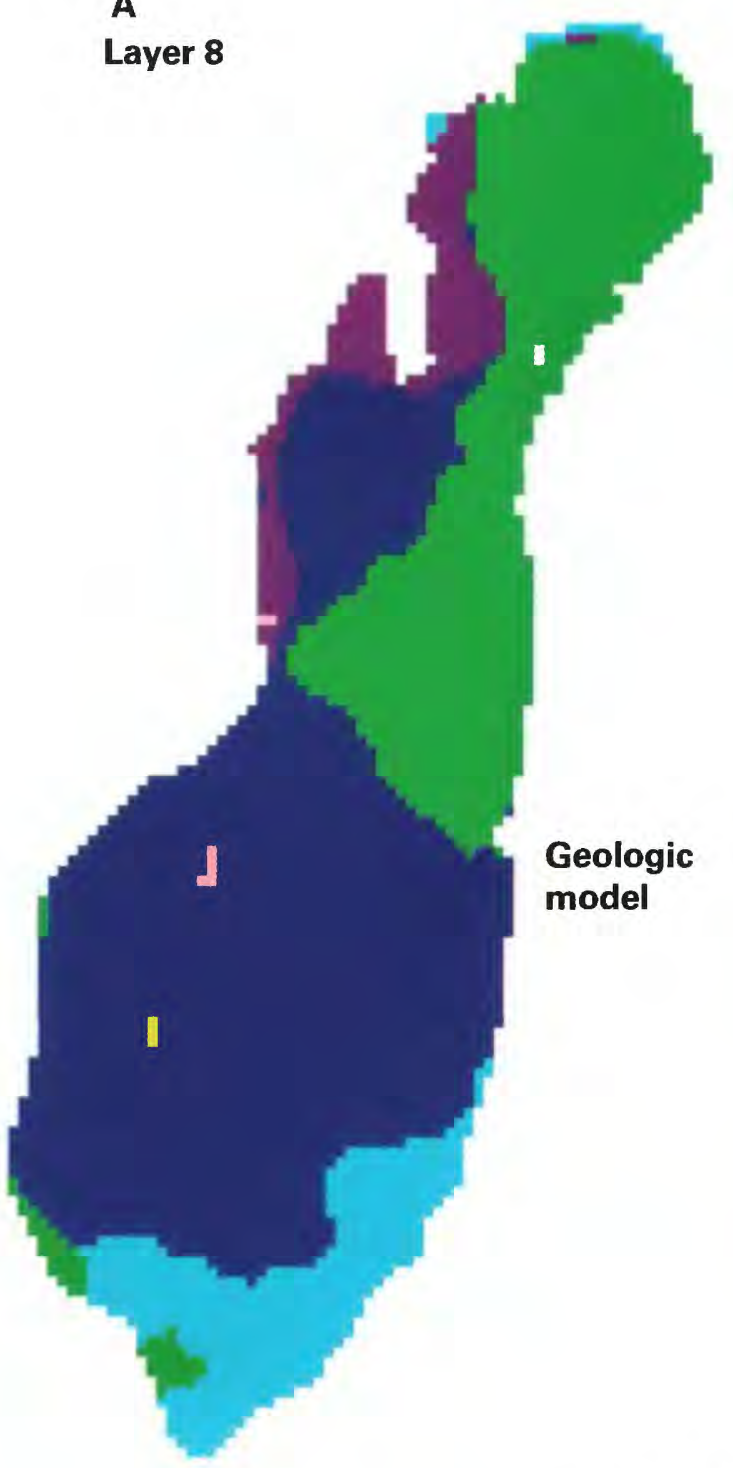

B

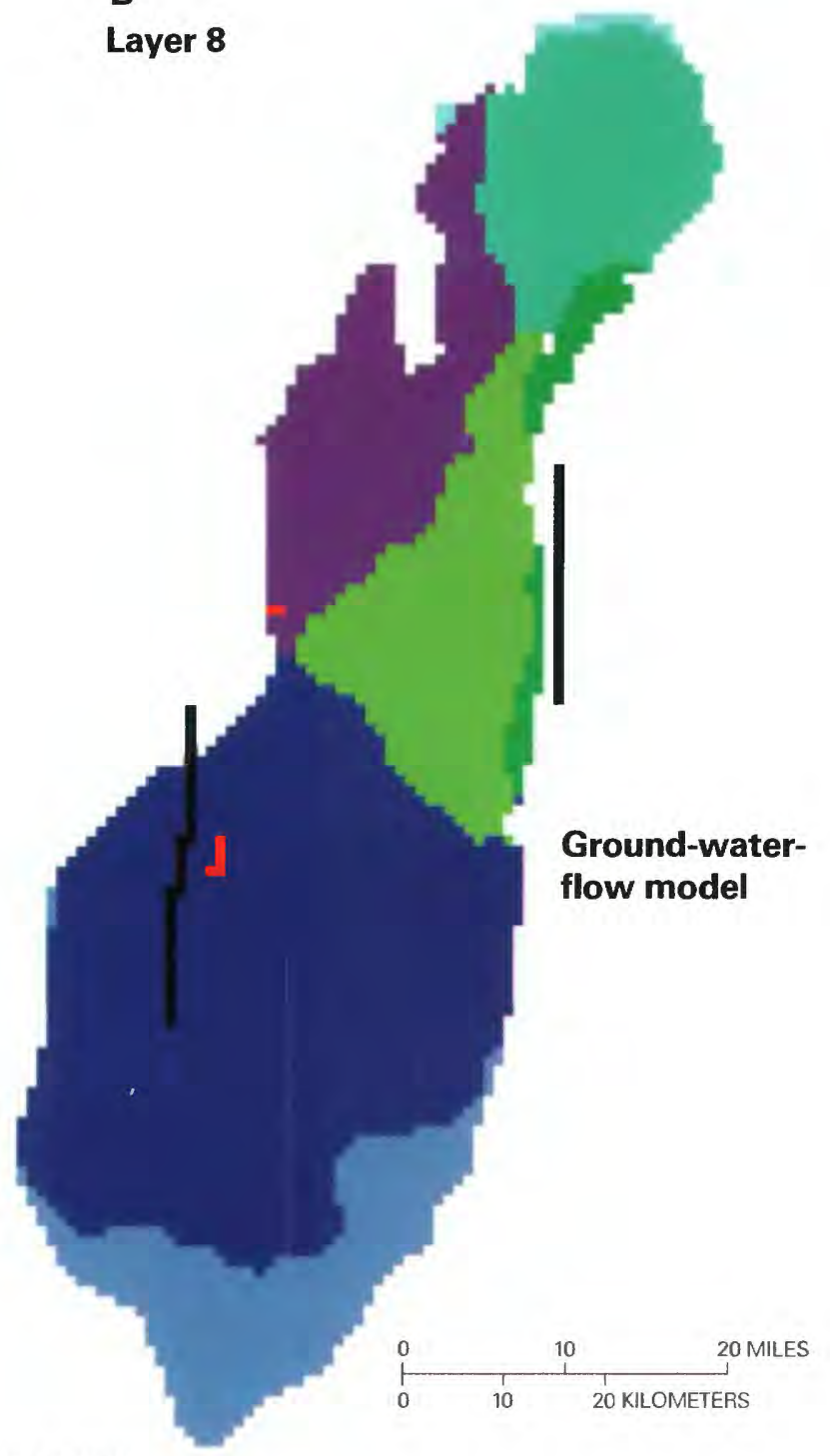

EXPLANATION

Zones of hydraulic conductivity in layer 8

Geologic model

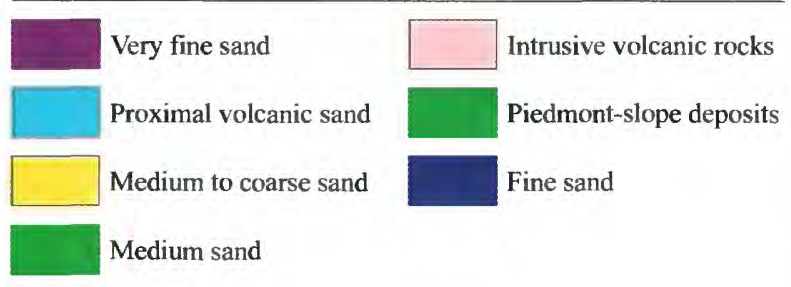

\begin{tabular}{|c|c|}
\hline \multicolumn{2}{|c|}{ Ground-water-flow model } \\
\hline Piedmont-slope deposits & $\begin{array}{l}\text { Central fine and } \\
\text { very fine sand }\end{array}$ \\
\hline Fine sand & Central medium sand \\
\hline $\begin{array}{l}\text { Northern proximal } \\
\text { volcanic sand }\end{array}$ & Northern medium sand \\
\hline $\begin{array}{l}\text { Southern proximal } \\
\text { volcanic sand }\end{array}$ & Volcanic rocks \\
\hline
\end{tabular}

Figure 25. Hydraulic conductivity zones of layer 8 as defined in (A) the geologic model of Cole (2000b), and (B) the ground-water-flow model. 
A

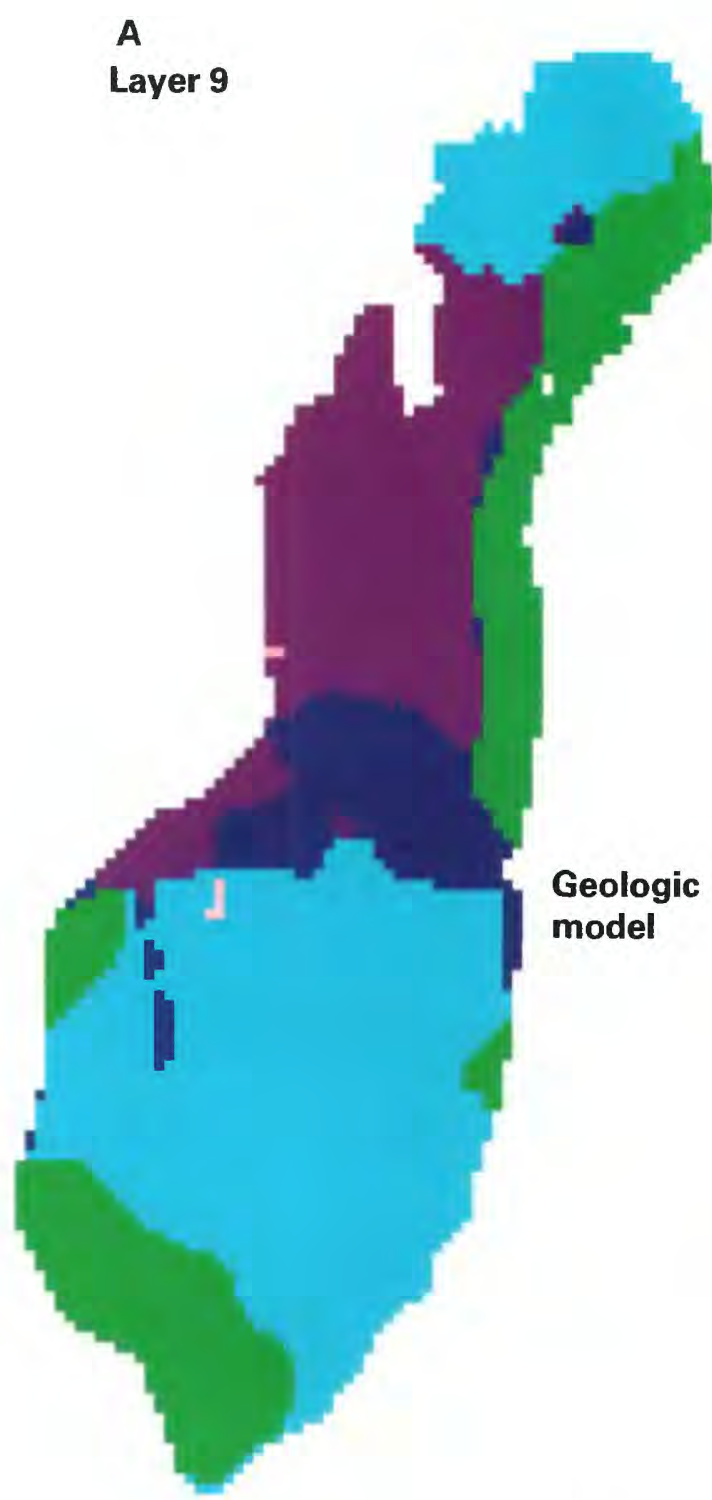

B

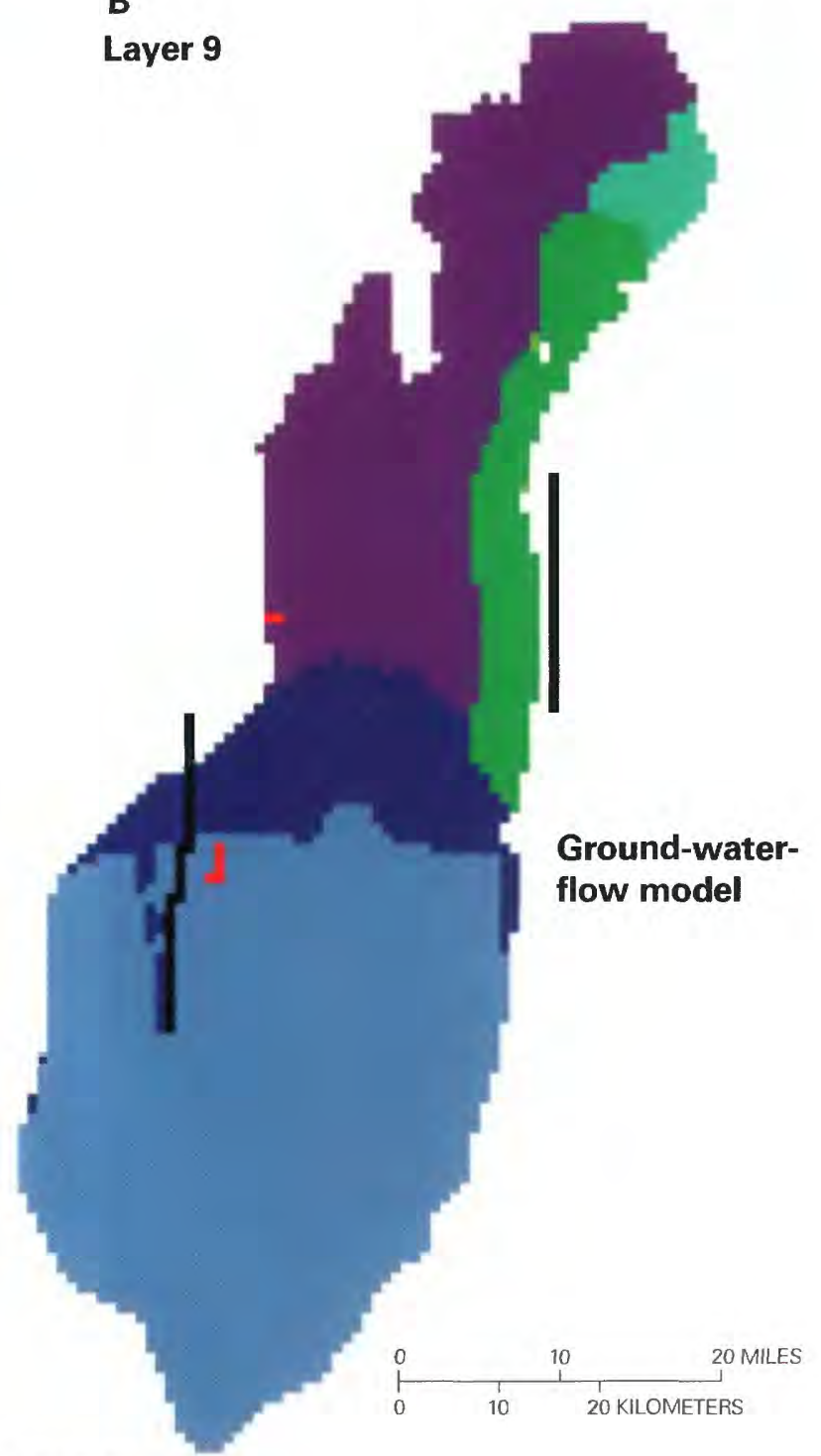

EXPLANATION

Zones of hydraulic conductivity in layer 9

Geologic model

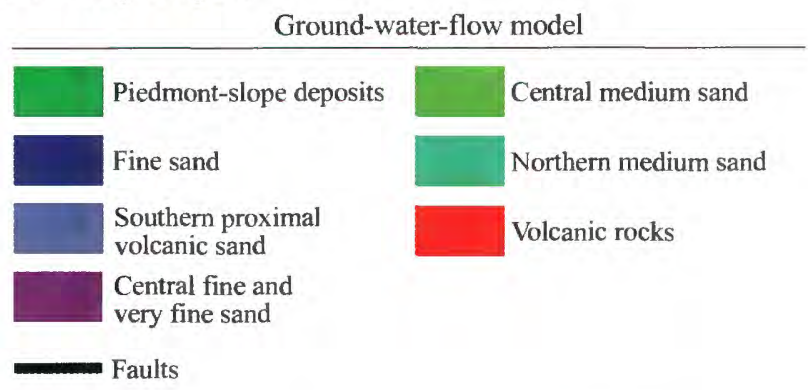

Figure 26. Hydraulic conductivity zones of layer 9 as defined in (A) the geologic model of Cole (2000b), and (B) the ground-water-flow model. 


\section{A}

\section{Row 22}

B

Row 60

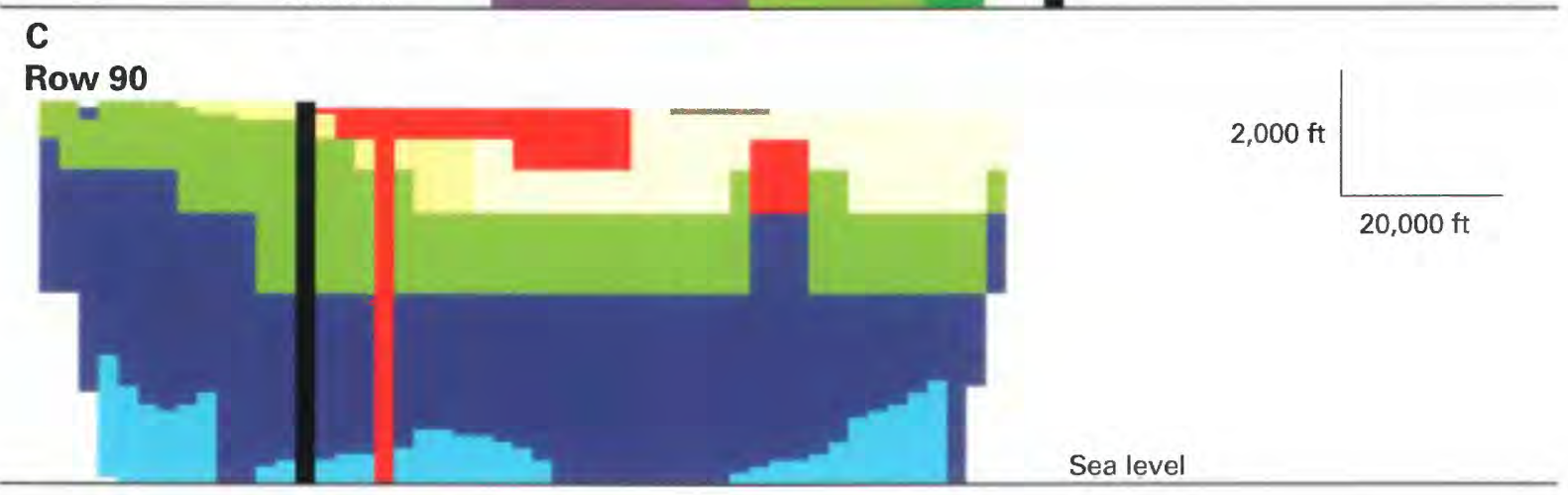

EXPLANATION

Cross-sectional zones of hydraulic conductivity zones along rows (A) 22 (B) 60, and (C) 90

Ground-water-flow model

\begin{tabular}{|c|c|c|}
\hline $\mathrm{cg}$ & Ceja gravels & Northwest medium sand \\
\hline & Piedmont-slope deposits & Northeast medium sand \\
\hline & Silts & West central medium sand \\
\hline & Fine sand & East central coarse sand \\
\hline & $\begin{array}{l}\text { Northern fluvial sand } \\
\text { and gravel }\end{array}$ & Southwest medium sand \\
\hline & $\begin{array}{l}\text { Central fluvial sand } \\
\text { and gravel }\end{array}$ & Southeast coarse sand \\
\hline & $\begin{array}{l}\text { Southern fluvial sand } \\
\text { and gravel }\end{array}$ & Central medium sand \\
\hline & $\begin{array}{l}\text { Southern proximal } \\
\text { volcanic sand }\end{array}$ & Northern medium sand \\
\hline & $\begin{array}{l}\text { Central fine and } \\
\text { very fine sand }\end{array}$ & Volcanic rocks \\
\hline
\end{tabular}

Figure 27. Cross-sectional views of the hydraulic conductivity zones along rows (A) 22, (B) 60 , and (C) 90 of the ground-water-flow model. See figure 18 for locations of section lines. 
be used to calculate a Darcian flux, the path line tracking routine uses the seepage velocity. The seepage velocity is equal to the Darcian flux divided by the effective porosity of the porous medium. Effective porosity is therefore a necessary parameter to specify or estimate in the calibration procedure. Ground-water ages provide inherent information on the ground-water flux, and therefore also on recharge rates. They do not, however, provide independent information on the recharge rate and the effective porosity (Medina and Carrera, 1996). On the other hand, porosities for the unconsolidated sediments of the MRGB can be constrained from field measurements with a degree of certainty that is significantly greater than that for recharge rates. In addition, effective and total porosity for granular porous media have very similar values. For these reasons, the effective porosity of the model was specified, rather than estimated during the calibration procedure.

Stone and Allen (1998) report total porosity values between 30 and 40 percent from a 1,500-foot core of the Santa Fe Group. Haneberg (1995) reports porosity values derived from geophysical logs that range from about 40 percent at the land surface to about 30 percent at a depth of 1,000 feet. These values are in agreement with values that are typical for unconsolidated silt- and sand-sized material (Driscoll, 1986). In addition, it is well established that porosity values trend lower in an exponential manner with increasing depth in sedimentary rocks (Athy, 1930). Based on this information, and on compilations of porosity-depth curves for the MRGB (Haneberg, 1995) and for sandstones (Giles, 1997, p. 224), porosities were assigned by layer, beginning with 36 percent for layer 1 and decreasing by 2 percent per layer down to 20 percent for layer 9 . Given that each deeper layer increases in thickness, the assigned porosities decrease in a fashion similar to an exponential decay curve.

\section{Simulated ${ }^{14} \mathrm{C}$ Activity Calculations}

There is more than one approach to using ground-water ages to calibrate a ground-water-flow model. One approach is to compare the simulated travel time with the ground-water age calculated from the ${ }^{14} \mathrm{C}$ activity. A second approach is to compare the ${ }^{14} \mathrm{C}$ activity with a simulated ${ }^{14} \mathrm{C}$ activity calculated from the simulated travel time. In this study the latter approach was used for two reasons. The first reason was based upon the degree to which the residuals (the difference between the simulated and observed values) influence the objective function in the linear regression model. For comparisons of ages, a 1,000-year difference for a 30,000-year age would carry the same influence as a 1,000-year difference for a 1,000-year age. Alternatively, for comparisons of ${ }^{14} \mathrm{C}$ activities, a 1-pmC (percent modern carbon) difference at 5 $\mathrm{pmC}$ would carry the same influence as a 1 -pmC difference at $90 \mathrm{pmC}$. The pmC differentials better reflect the relative uncertainty between old and young ages that exists in the ${ }^{14} \mathrm{C}$ dating method than the age differentials. The weights could not be used to reflect the age-related uncertainties because the weights were used to reflect uncertainty associated with mixing in long-screened wells. The second reason was because of mixing that occurs in long-screened wells. More than one path line was often used per well, and to properly calculate one value for the well, activities need to be averaged rather than ages of the individual flow lines.

The relation between the simulated ${ }^{14} \mathrm{C}$ activity and ground-water age is based on exponential decay, and is given by the equation:

$$
\mathrm{pmC}=\mathrm{A}_{\mathrm{o}} /(\exp (\operatorname{time} * \ln (2 .) / 5,730 .))
$$

where pmC is the simulated ${ }^{14} \mathrm{C}$ activity; $\mathrm{A}_{0}$ is the ${ }^{14} \mathrm{C}$ activity at the recharge location; "time" is the simulated travel time from MODPATH plus, when necessary; initial age is as described below; and 5,730 is the half-life of ${ }^{14} \mathrm{C}$, in years. Activities of ${ }^{14} \mathrm{C}$ also are affected along their flow paths by geochemical reactions. The ${ }^{14} \mathrm{C}$ activities in the study were all adjusted for geochemical reactions, and the results are described in detail by Plummer and others (2004). In addition, ${ }^{14} \mathrm{C}$ activities in the atmosphere varied over the past 24,000 years. Based on data by Stuiver and others (1998) and a calibrated curve by Kalin (2000), Plummer and others (2004) used a polynomial expression to relate calendar years to ${ }^{14} \mathrm{C}$ years. The geochemical reactions and the transient atmospheric effects were incorporated into a value of $\mathrm{A}_{\mathrm{o}}$ assigned to each individual ${ }^{14} \mathrm{C}$ activity (eq. 2). In MODPATH one parcel of water was tracked backward for each 100 feet of observation well screen. The simulated ${ }^{14} \mathrm{C}$ age for each parcel was calculated individually and then the average age was calculated for the entire observation well. For long-screened city production wells, as many as 12 parcels were used. In this manner, a mixing effect was added to the final simulated ${ }^{14} \mathrm{C}$ age for longscreened wells.

The backward tracking in MODPATH brings the particles or path lines to the location where that water would have entered the model of the basin. In many circumstances this boundary of the basin does not coincide with a recharge location for the water where the ${ }^{14} \mathrm{C}$ activity would obtain its initial value. Underflow boundaries from bounding basins are the most common example of this, but also along the eastern mountain front, there are stretches where the water would actually have entered the subsurface many miles to the east of the model boundary (fig. 14). For these situations, an.initial age has to be assigned for the water as it enters the basin. This initial age must be added to the path line age calculated by MODPATH. These initial ages were treated as parameters in the model that were estimated during the inverse procedure. Such inflow ages may vary along any one boundary, but no field data are available for comparisons, and in order for the number of estimated parameters not to become too large, a single value was estimated for each boundary. 


\section{MODEL CALIBRATION}

The ground-water-flow model was calibrated using a combination of nonlinear least-squares regression method as it is implemented in the computer code UCODE (Poeter and Hill, 1998), and manual adjustment of individual parameters. UCODE is designed for inverse modeling of problems posed as parameter-estimation problems. Any application model or models can be used; the only requirement is that they have ASCII input and output files. UCODE acts as a shell that repeatedly calls the application models, automatically adjusting input parameters and extracting and comparing output values until a minimum is reached in the error between observed and simulated data. For this study MODFLOW, MODPATH, and a small number of pre- and post-processing routines were called by UCODE for each iteration.

\section{Nonlinear Regression Method}

In the regression procedure, optimal parameter values are estimated by minimizing the squared weighted differences between observed and simulated values in an objective function (Hill, 1998):

$$
S(b)=\sum_{i=1}^{n}\left[w_{i}^{1 / 2} e_{i}\right]^{2}
$$

where $b=$ vector of parameters to be estimated;

$n=$ number of measurements;

$w_{\bar{i}}=$ weight on difference $e_{i} ;$ and

$e_{i}=$ residual (difference between observed and simulated value) for measurement $i$.

The residual $e$, is equal to the difference between an observed $\left(y_{i}\right)$ and simulated $\left(\hat{y}_{i}(b)\right)$ quantity. In this study, $y_{i}$ represents a measured hydraulic head, ${ }^{14} \mathrm{C}$ activity, or percentage of ground water originating from a particular source, and $\hat{y}_{i}$ represents the simulated equivalent of $y_{i}$. The minimization of the objective function (eq. 3 ) is performed by the modified Gauss-Newton method (Cooley and Naff, 1990; Hill, 1992).

The weight given to any residual reflects the relative importance of matching that particular observation, and often is related to the accuracy of the measurement. In this study $w_{i}$ is generally calculated as the inverse of the estimated variance of the measurement error, following procedures suggested by Hill $(1992,1998)$. By using this method, highly accurate measurements, which have small variance, have relatively large weights, whereas less accurate measurements, with large variance, have relatively small weights. Furthermore, the weighted differences, $w_{i}^{-} e_{i}$, are dimensionless numbers; therefore, squared weighted differences for quantities with different units, such as hydraulic head and ${ }^{14} \mathrm{C}$ activity, can be summed in the objective function (eq. 3 ).

In the process of minimizing the objective function, the regression procedure computes the sensitivity of simulated head or activity $i$ at observation location $i$ to each model parameter $b_{j}$. These sensitivities, $\partial_{i} / \partial b_{j}$, are a measure of the change in the simulated observation resulting from a small change in the parameter value. In terms of regression, the sensitivities indicate how much information a particular observation provides toward estimating a particular parameter. The amount of information all observations provide toward estimating a single parameter can be expressed by a summary statistic, the composite scaled sensitivity (CSS). The CSS for parameter $j$ is expressed as (Hill, 1998):

$$
C S S_{j}=\left\{\frac{\sum_{i=1}^{n} w_{i}\left(\frac{\partial \hat{y}_{i}}{\partial b_{j}} b_{j}\right)^{2}}{n}\right\}^{\frac{1}{2}}
$$

Because this measure is scaled by the parameter value $b_{j}$, its value for different parameters can be compared and used to choose the set of parameters to estimate in the regression procedure. Parameters with larger values of CSS are those to which the data as a whole are more sensitive and therefore more likely to be estimated by the regression. Parameters with smaller values of CSS are those to which the data as a whole are less sensitive.

In this study, six programs were called by UCODE. The code names were PREP, MODFLOW, MODPATH, ENDYEAR, POST, and GETHEADS (appendix B). The code PREP was used to create the MODFLOW input files from the parameter values of recharge, hydraulic conductivities, and underflows as they were to be assigned to different regions within the model domain. A parameter-input file, PARAMS, was created that could be modified easily by hand between calibration runs. This PARAMS file contained a list of all of the parameters that would be perturbed or modified by UCODE during the calibration procedure. During each UCODE iteration cycle, PREP would read the PARAMS file to create the MODFLOW input files. MODFLOW was run to produce simulated heads and cell-by-cell flow rates. MODPATH was run using the cell-by-cell flow rates to calculate a travel time, or ground-water age, for each 100 -foot section within an observation well. MODPATH was also run to determine the recharge or source location of each particle within the hydrochemical-target regions. ENDYEAR was used to convert MODPATH output into simulated ${ }^{14} \mathrm{C}$ activities for each of the calculated MODPATH ages. POST was used to compile the individual simulated ${ }^{14} \mathrm{C}$ activities into a composite simulated ${ }^{14} \mathrm{C}$ activity for each well. POST was also used to determine the percentage of a hydrochemical-targeted region whose water originated from a local river (the Rio Grande or Rio Puerco). This technique is described further in the section on "Hydrochemical-Zone Observations."

After the UCODE run, individual parameters were adjusted further to obtain a better fit. Accuracy of the sensitivity calculations was limited by the discrete nature of the path 
line calculations. Small changes in the parameters could make sudden shifts in path lines from wells to new source areas, creating an associated jump in travel time. UCODE was also used to run multiple simulations varying only one parameter at a time over a finite range of values. In this way, the discrete jumps in the global error were observed, and the minimum error and associated value for each parameter could also be determined. All of the individual parameters were examined in this way, adjusting the value of each one in order to lower the global error. The entire set of parameters was reevaluated consecutively in this fashion three times, after which the global error no longer decreased by an appreciable amount.

\section{Calibration Data Sets}

Multiple types of data were used in this study to calibrate the ground-water-flow model. Hydraulic heads, ${ }^{14} \mathrm{C}$ activities, and the locations of the hydrochemical zones were all used as observations in the objective function (eq. 3). These values were all given weights in accordance with their perceived or estimated accuracy. A total of 200 hydraulic heads, $200{ }^{14} \mathrm{C}$ activities, and the locations of two of the river-water hydrochemical zones within nine hydrochemical-target regions were used as observations, making a total of 409 observations.

\section{Water-Level Observations}

The ground-water-flow model was designed to simulate steady-state ground-water flow prior to the development of ground water as a resource within the basin. To calibrate the model, hydraulic-head data were needed that did not show the influence of any appreciable ground-water withdrawals that have occurred within the basin over the last half century. The data were compiled from many sources; these various sources are described by Bexfield and Anderholm (2000), and much of the data are presented in their map of the predevelopment water table. The sources of the data include domestic wells, windmills, pueblo wells, and monitoring wells. Data from wells within the vicinity of the city of Albuquerque were used only if they were measured before 1960 . Those that were measured during the 1950s were chosen carefully to exclude wells cited close to visible cones of depression. Wells far from the city were assumed to have water levels that contained negligible effects from anthropogenic stresses. Only water levels from the time of well installation were used at producing wells.

Two hundred hydraulic-head values were used in total (table A1; fig. 28). The screen depths from the wells were used to determine the layer in which the well would be located in the ground-water-flow model. Well locations typically do not fall exactly on cell-center coordinates, so to obtain the equivalent simulated value, hydraulic heads were calculated using heads from several cells. A trilinear interpolation scheme was used that interpolated the head value between the cells of the nearest two rows, columns, and layers. A separate FORTRAN code was written called GETHEADS (appendix
B) that read all of the heads from the MODFLOW output file and then performed the interpolation calculations to obtain the 200 simulated hydraulic-head observations. These simulated observations were then written to another output file with the prefix "heads." This heads file was the file from which UCODE extracted the simulated observations. The expected measurement errors for the hydraulic heads in the data set were estimated as expected standard deviations, and were assigned values between 1 foot for recent surveyed monitoring wells, to 10 feet or more for domestic wells where the measuring-point altitude was estimated from a topographic map. These estimated measurement errors were used to assign weights to the head observations.

\section{${ }^{14} \mathrm{C}$-Activity Observations}

The activity of ${ }^{14} \mathrm{C}$ was measured in samples taken from over 200 wells and river locations throughout the basin. Locations of the 200 well-sample sites used for observations are shown in figure 29 , and the ${ }^{14} \mathrm{C}$ activities and the associated ages are given in table A2 (p. 82-87). These sites include areas of active pumping because the withdrawals only remove water within close proximity of the wells, and ages will still reflect patterns of regional ground-water movement. Estimates of the geochemical reactions that occurred within the basin to alter the ${ }^{14} \mathrm{C}$ activities were made by Plummer and others (2004), who compiled a list of values for $A_{o}$ that account for these reactions and long-term atmospheric variations. These $\mathrm{A}_{\mathrm{o}}$ values, listed in table $\mathrm{A} 2$, were used to calculate the simulated ${ }^{14} \mathrm{C}$ activities from the simulated travel times (eq. 2). In addition to the activities and ages, information is given in table A2 on the cell location with the flow model, the number of MODPATH flow lines tracked from each well, and the uncertainty assigned to each age estimate. For each ${ }^{14} \mathrm{C}$-age observation, a simulated age observation was determined using the backward-tracking option in MODPATH. Because wells can produce mixtures of waters that have traveled along different flow paths, multiple flow paths were simulated for long-screened wells.

Observations should be weighted based on the relative uncertainty associated with each measurement (Hill, 1998). Plummer and others (2004) made estimates of uncertainties in the ${ }^{14} \mathrm{C}$ activities measured at the wells (table A2). Additional uncertainty is related to how the influx of water to a well varies vertically within the well screen. This variation in vertical influx makes the full uncertainty difficult to evaluate on a well-by-well basis, and thus a simple scheme was adopted where an uncertainty of 1 or $5 \mathrm{pmC}$ was assigned to short- and long-screened wells, respectively. These uncertainty values, rather than those from Plummer and others (2004), were assigned to the observations in the UCODE files, and each ${ }^{14} \mathrm{C}$ observation was weighted based upon these values. The uncertainties in the ${ }^{14} \mathrm{C}$ activities (table A2) are expressed in terms of the standard deviation for the activity. The weights for each of these observations are a function of the inverse of the standard deviation. Thus the short-screened wells with a 


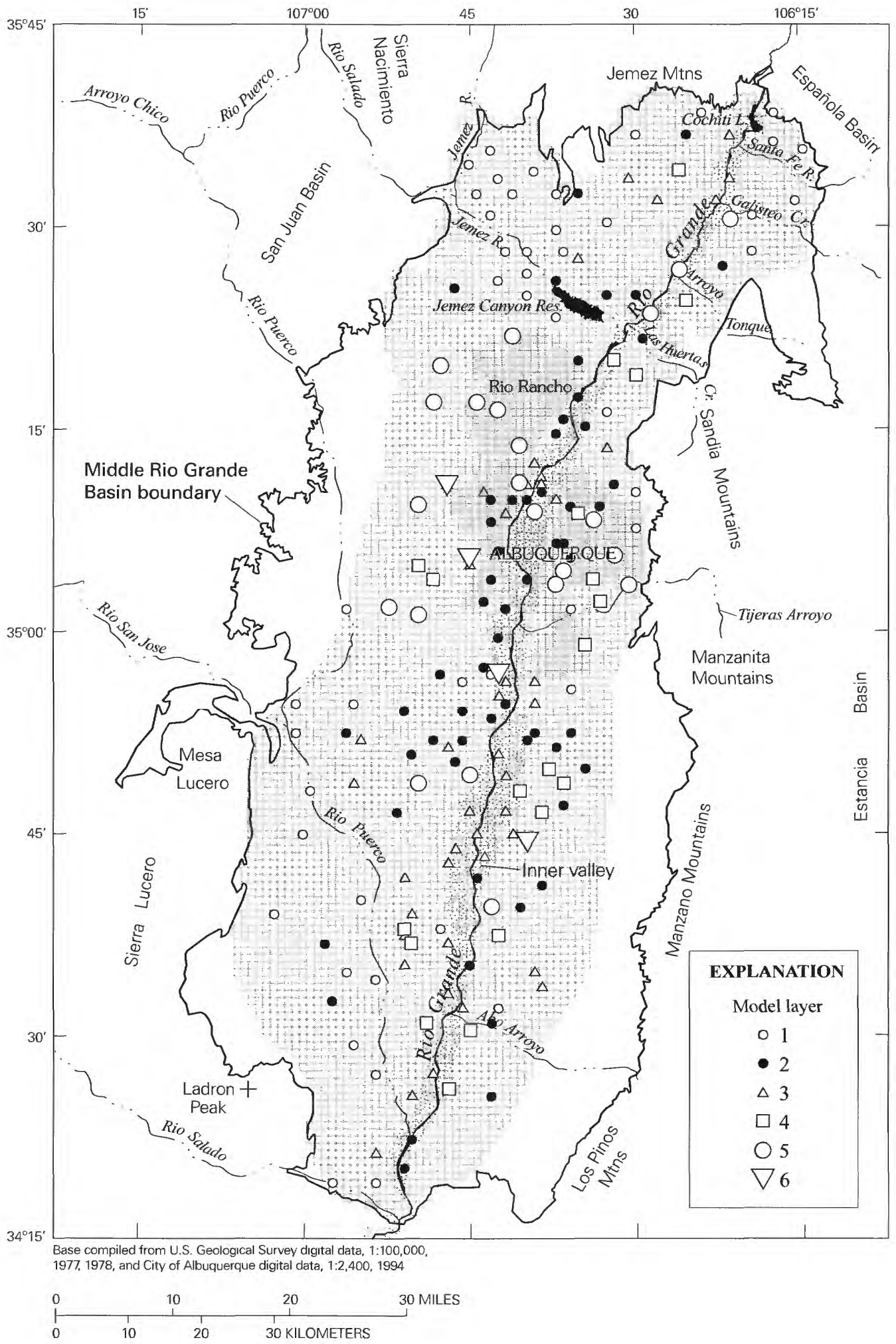

Figure 28. Location of hydraulic-head observations used to calibrate the predevelopment ground-water-flow model. 


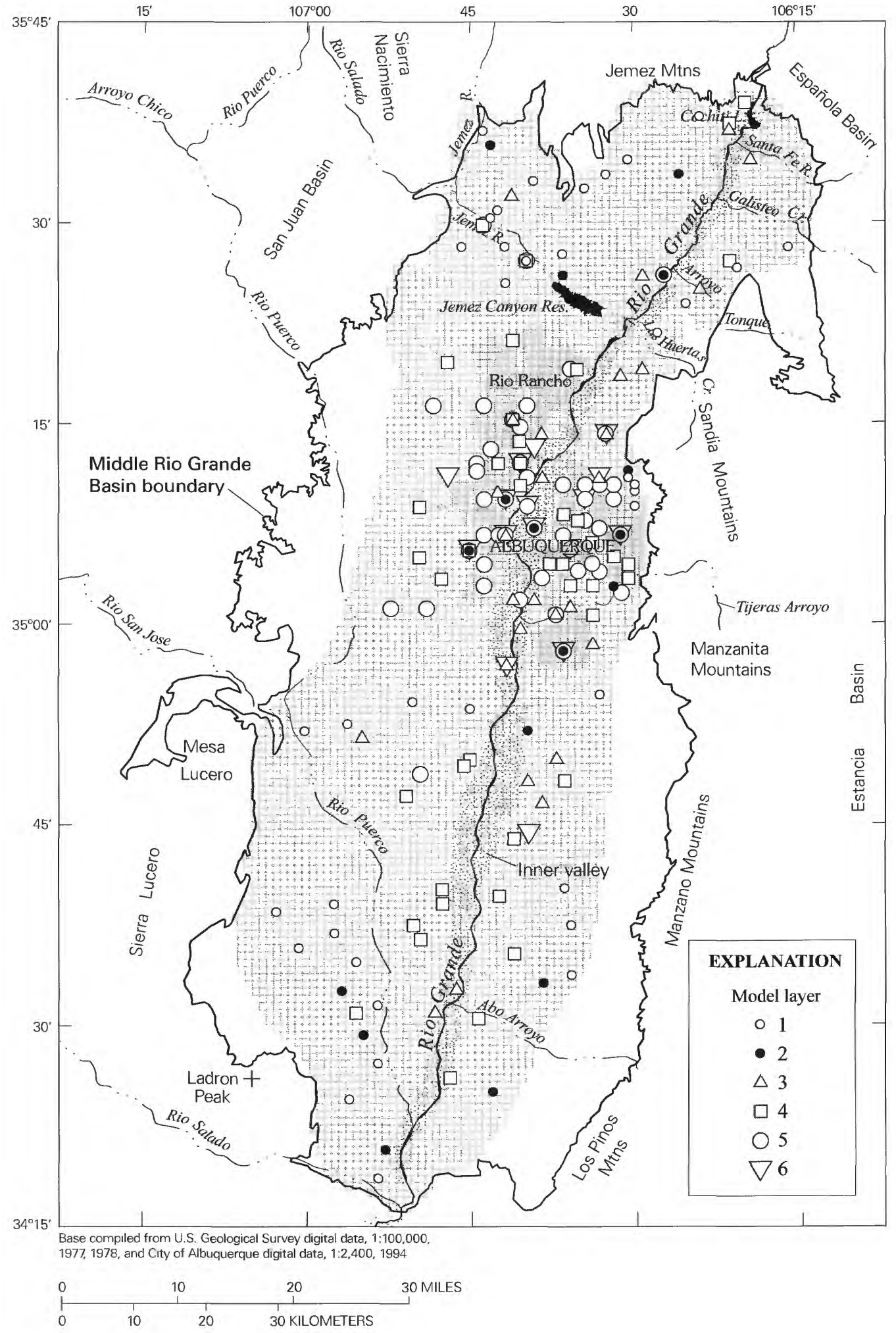

Figure 29. Location of carbon-14 samples used to calibrate the predevelopment ground-water-flow model. 
standard deviation of $1 \mathrm{pmC}$ are weighted five times more than the long-screened wells with a standard deviation of $5 \mathrm{pmC}$.

\section{Hydrochemical-Zone Observations}

In addition to water levels and ${ }^{14} \mathrm{C}$ activities, the location and extent of selected hydrochemical zones were used as observations. Earlier pilot simulations (Sanford and others, 1998) indicated that the volume of Rio Grande and Rio Puerco water in the basin aquifer system would depend upon the recharge and hydraulic conductivity parameters of the model. The less the recharge along the margins of the basin, or the higher the hydraulic conductivity of the aquifer, the broader is the areal extent of the recharged river water that is adjacent to the river. In the case of the Rio Puerco and the Jemez River, the extent of river water in the basin is also very sensitive to the vertical hydraulic conductance of the riverbed. Zones of river water can be observed based on their geochemical signature. The hydrochemical zones described by Plummer and others (2004) and in table 1 include zones described as Rio Grande water (zone 12), and Rio Puerco water (zone 5). Jemez River water was not considered as a separate zone because it was found only in a few wells very near the river. The boundaries between the river-water zones and the other hydrochemical zones in the basin are shown in figure 9 . The positions of such boundaries are known (from the earlier pilot studies) to be a function of recharge, hydraulic conductivity, and riverbed conductance, and the simulated positions of the boundaries could, therefore, also be used as observations in the model calibration using UCODE.

The nonlinear regression routine requires that simulated observations be continuous functions of the parameter values, because small perturbations of the parameter values must register as a finite change in the simulated observations. The hydrochemical zones, however, represent discrete regions where water simulated to migrate to a certain point in the aquifer system either did, or did not, originate from a source location with a recognizable geochemical signature. A method was needed whereby path lines simulated using MODPATH would register the source location of the water in such a way as to make a continuous or near-continuous function. To accomplish this, nine rectangular hydrochemical "target regions" were created that partially encompassed river-water zones defined by the geochemistry (fig. 30). These hydrochemicaltarget regions were used as observations, bringing the total number of observations for the regression analysis to 409 . The observation value was the percentage of river water observed to be in any target region based on the hydrochemical zones. To simulate this, a fine array of particles covering evenly each target region was tracked backward to their sources (table 2) using MODPATH. The number of paths that tracked to river cells was then divided by the total number of paths for that target region. The very large number of particles allowed this simulated percentage to vary by finite and significant amounts when each parameter was perturbed by only a few percent. Therefore, although the responses of the simulated observations are not continuous at an infinitesimally small parameter perturbation, they are continuous at the size of perturbations used in these simulations, and thus allow for the use of the nonlinear regression methods.

\section{Sensitivities}

The composite scaled sensitivities were calculated for each of the parameters from the MODFLOW and MODPATH model simulations (fig. 31 and 32). Based partially on the magnitude of the sensitivity and partially on the availability of prior information, some parameters were assigned values and others were estimated using the nonlinear regression. The parameters with the highest sensitivity were the hydraulic conductivities in the northeastern, central, and southern basin (hcsfne, hcsfsw, hcsfse, hcsfce, hcalal, hcsfcw, and hclsfs), the anisotropy of the Rio Grande alluvium near Albuquerque (analal), recharge values for the southern Sandia Mountain front (snsandias, sssandias), and underflow from the northern

Table 2. Information on geochemical-target regions (fig. 30) defined for use in calibration against the geochemical zones.

\begin{tabular}{|c|c|c|c|c|c|c|c|c|c|}
\hline $\begin{array}{l}\text { Region } \\
\text { number }\end{array}$ & Region name & $\begin{array}{c}\text { Layer } \\
\text { number }\end{array}$ & $\begin{array}{c}\text { Ending } \\
\text { row } \\
\text { number }\end{array}$ & $\begin{array}{l}\text { Begin- } \\
\text { ning row } \\
\text { number }\end{array}$ & $\begin{array}{c}\text { Beginning } \\
\text { column } \\
\text { number }\end{array}$ & $\begin{array}{l}\text { Ending } \\
\text { column } \\
\text { number }\end{array}$ & \begin{tabular}{l}
\multicolumn{1}{c}{ Total } \\
number of \\
path lines \\
in region
\end{tabular} & $\begin{array}{l}\text { Approximate } \\
\text { number of } \\
\text { path lines with } \\
\text { river origin }\end{array}$ & $\begin{array}{c}\text { Fraction of } \\
\text { region } \\
\text { containing } \\
\text { river water }\end{array}$ \\
\hline 1 & Rio Grande Northwest & 2 & 47 & 76 & 26 & 45 & 5,400 & 2,160 & 0.40 \\
\hline 2 & Rio Grande Northeast & 2 & 47 & 76 & 46 & 55 & 2,583 & 1,350 & 0.52 \\
\hline 3 & Rio Grande Southwest & 2 & 77 & 106 & 26 & 40 & 4,050 & 1,890 & 0.47 \\
\hline 4 & Rio Grande Southeast & 2 & 77 & 106 & 41 & 50 & 2,634 & 900 & 0.34 \\
\hline 5 & Rio Grande South & 2 & 107 & 136 & 26 & 40 & 3,843 & 500 & 0.13 \\
\hline 6 & Rio Puerco North & 2 & 72 & 96 & 1 & 25 & 4,725 & 1,800 & 0.38 \\
\hline 7 & Rio Puerco West & 2 & 97 & 121 & 1 & 15 & 3,096 & 540 & 0.17 \\
\hline 8 & Rio Puerco East & 2 & 97 & 121 & 16 & 25 & 2,250 & 1,800 & 0.80 \\
\hline 9 & Rio Puerco South & 2 & 122 & 146 & 11 & 25 & 3,330 & 1,440 & 0.43 \\
\hline
\end{tabular}




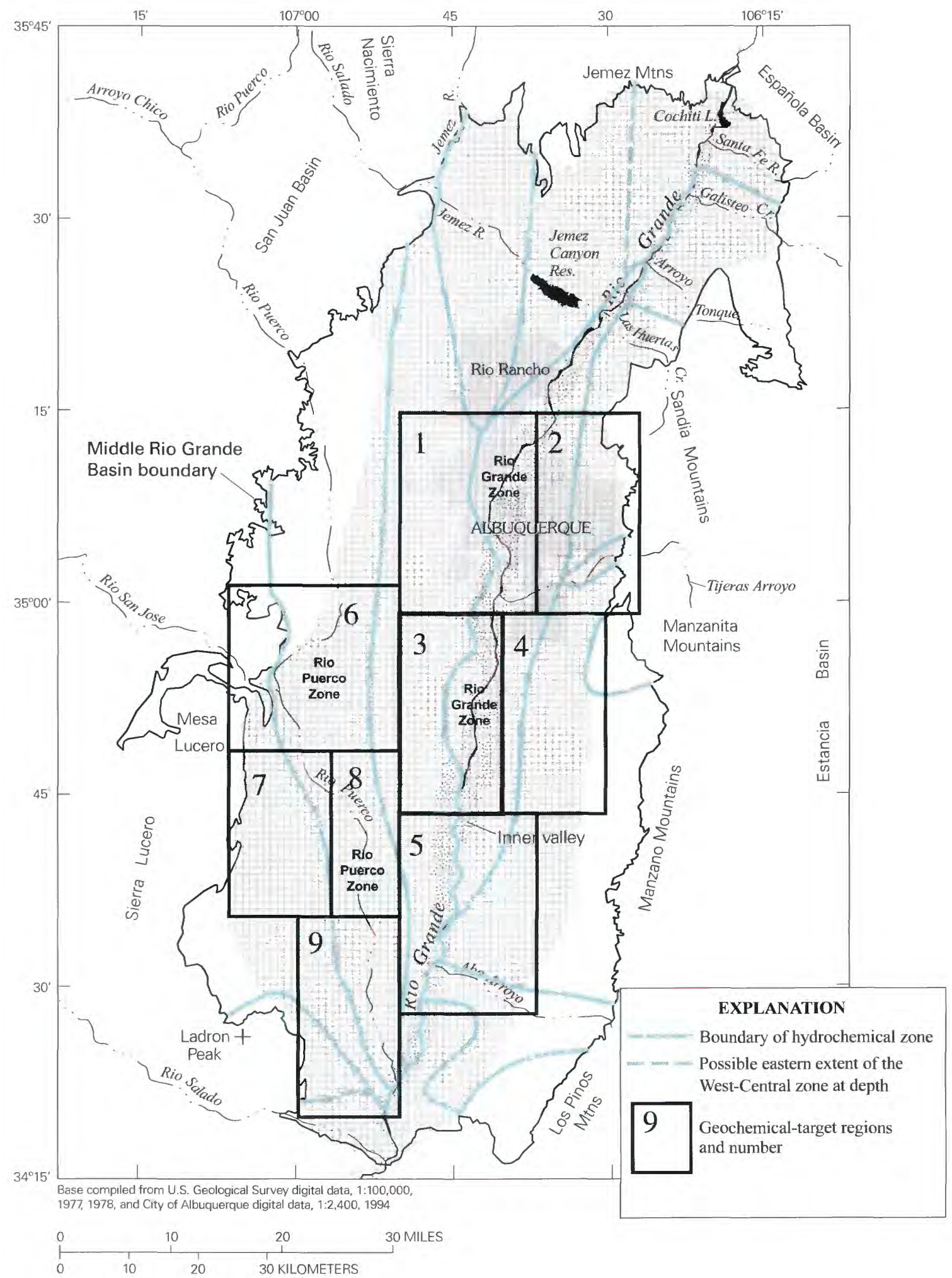

Figure 30. Location of geochemical-target regions used to calibrate the ground-water flow model. 


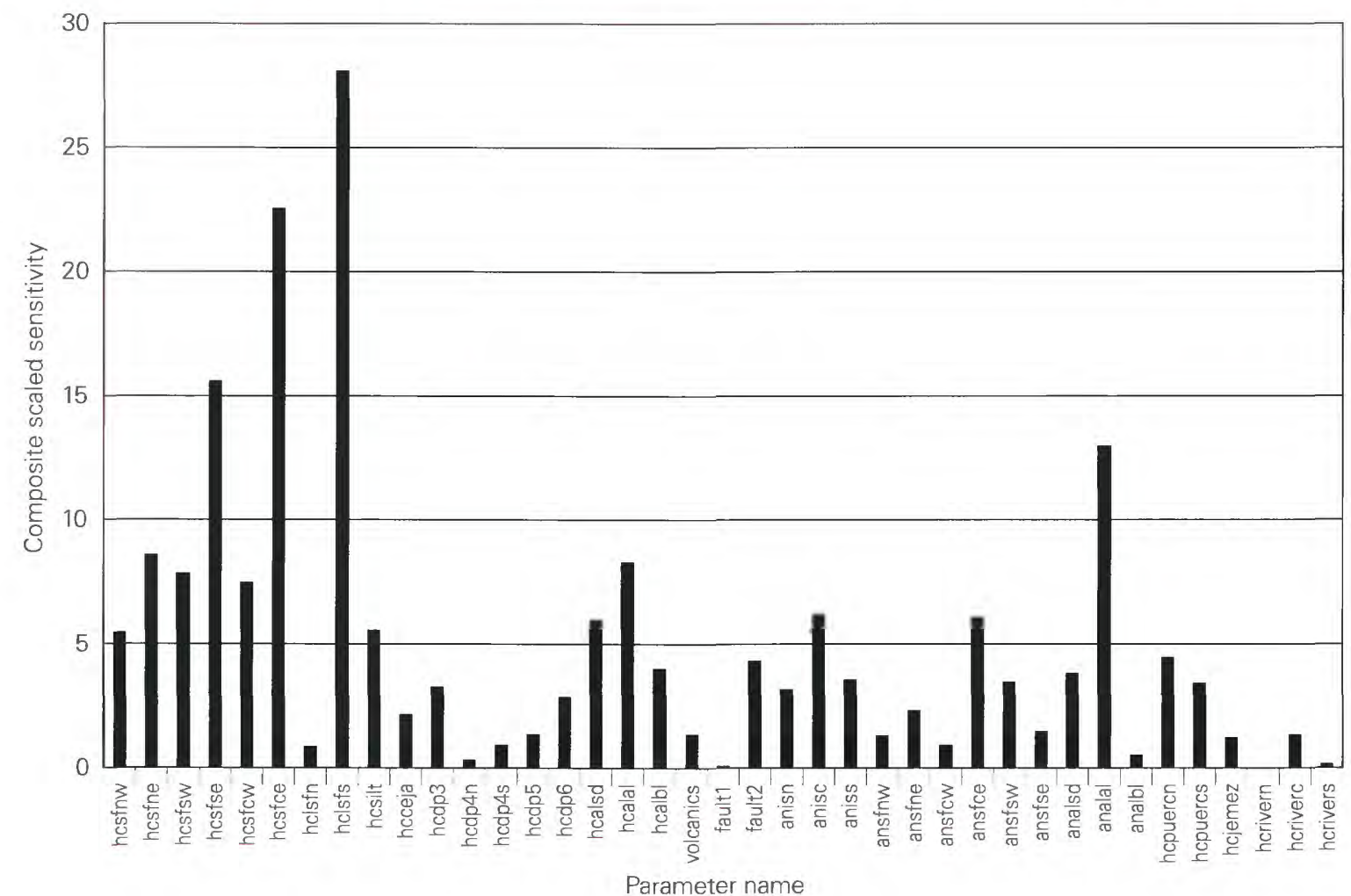

Figure 31. Composite-scaled sensitivities for parameters of hydraulic conductivity, anisotropy, and riverbed conductance at the optimized or specified values (see table 3 for parameter descriptions, locations, and values).

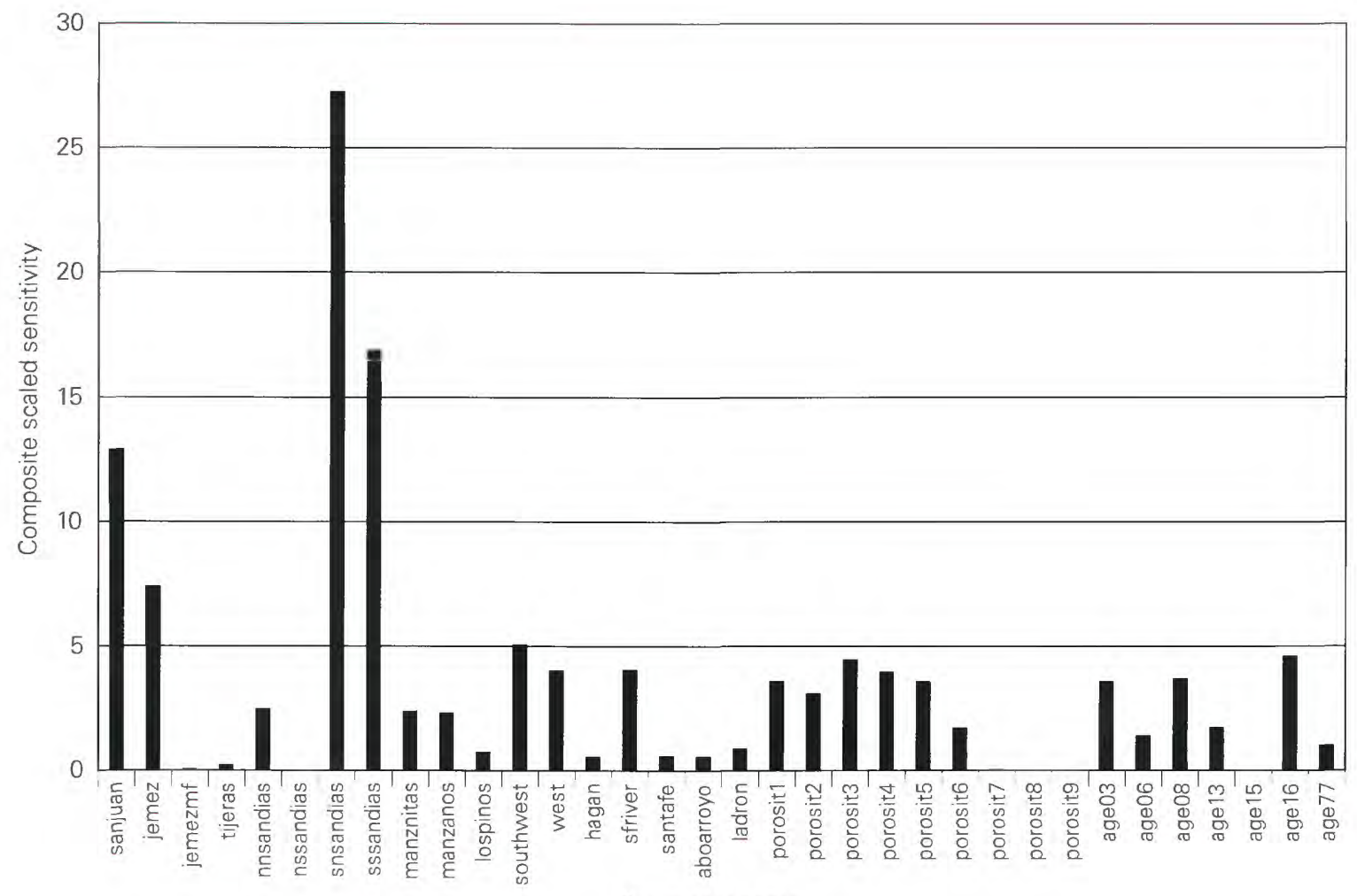

Parameter name

Figure 32. Composite-scaled sensitivities for parameters of recharge, porosity, and initial underflow age at the optimized or specified values (see table 3 for parameter descriptions, locations, and values). 
(jemez) and northwestern (sanjuan) boundaries. More detailed descriptions of the parameters are provided in table 3 . The composite scaled sensitivity values shown in figures 31 and 32 were calculated based on the best-fit parameter values for the simulations. Based on low sensitivity values, values were assigned to the vertical leakance of the northern (hcrivern) and southern (hcrivers) sections of the Rio Grande $(1,000,000$ feet per day), and to the hydraulic conductivity of the Cat Mesa Fault Zone (fault1) (0.000001 feet per day). Beyond the fact that the model indicated that the values of hcrivern and hcrivers should be very high, and the value of fault1 very low, the observation data did not provide enough information to the model for these values to be estimated with any certainty. Porosity values were assigned because reasonable estimates could be made from field data.

\section{MODEL RESULTS}

Simulations of ground-water levels and path line tracks were completed in two stages. The goal for these stages was to obtain a set of parameters for the flow model that would yield a best fit with the observed data. The nonlinear regression methods in UCODE improved the fit of the model considerably relative to fit based on the initial guesses. After a point of convergence was reached, individual parameters were adjusted further manually to obtain a better fit. The results presented here are from the simulation with the final best fit of parameter values to the data.

\section{Hydraulic Heads}

The hydraulic heads from the final simulation are shown for layers 2 and 6 in figures 33 and 34. Values of heads at individual wells are given in table A3 (pages 88-92). One of the features in the water levels that has been an enigma for years is the presence of a lower region in the potentiometric surface in the west-central section of the basin (see the observed predevelopment water table map, fig. 4) often referred to as the "trough." The current model configuration reproduces this feature, although not as far north as the some of the observed water levels indicate. The observed trough is still much deeper north of Albuquerque than this model shows. This region is one of sparse field data, and hydrogeologic conditions likely exist there that have not been included in any of the models. The current model also shows just a hint of the trough in the deeper section (layer 6) in the region of Rio Rancho. The geochemical zones are partly consistent with the presence of a trough. This partial consistency is discussed later in the "Hydrochemical Zones" section.

Earlier prototype models by Sanford and others (1998) demonstrated that by lowering basin underflow or mountainfront recharge in the model, the system changed from one dominated by the movement of water from the basin boundaries toward the Rio Grande to one dominated by water leaking from and back into the Rio Grande. This conceptual system of low recharge would create heads to the west of the Rio Grande that are lower than the river, such as are present in the trough. Low recharge is also a condition consistent with results of this study (reported in a later section). McAda and Barroll (2002) included in their model some lower values of recharge, some additional north-south-trending faults, and zones of increased north-south hydraulic conductivity in the region of the trough, but the trough is not readily apparent in the hydraulic head map for their predevelopment simulation.

Another main feature visible from the hydraulic head maps is the barrier specified at the Cat Mesa Fault Zone in the southwestern quadrant of the model. Water levels in wells a short distance from each other across this fault zone differ by more than $\mathbf{1 0 0}$ feet, suggesting the fault zone acts as a barrier to flow. The zone was simulated with a very low permeability. Early attempts to estimate the permeability of the zone with nonlinear regression were unsuccessful. The model continued to suggest the permeability value to be lower, and the sensitivity of the data to the low value also continued to decrease. The West Sandia Fault Zone, on the east side of the city of Albuquerque, also acts as a detectable barrier to flow. Water levels change abruptly by more than 200 feet across the fault zone. This feature can be reproduced readily in the model by an adjustment to the hydraulic conductivity of the fault zone and the recharge along that section of the mountain front. Both the hydraulic conductivity and recharge can be adjusted independently by the inverse model because ground-water ages there give additional data that are independent of water levels.

The model in this study reproduces the losing section of the Rio Grande just north of Albuquerque (fig. 35). From the contours one can see that water from the Rio Grande moves out of the Inner valley not only to the west toward the trough, but also to the south beneath the city of Albuquerque, as is also shown in the predevelopment water-table map (fig. 4). The zone of Rio Grande water beneath the city is also corroborated by the geochemical data (fig. 9). The earlier version of the model did not reproduce this feature (Kernodle and others 1995, p. 41) - the difference being that the high eastern mountain-front recharge values in the older model overwhelmed any tendency for water to move from the Inner valley into the regional aquifer system. Tiedeman and others (1998) also used high recharge values and showed water beneath the city moving toward the Inner valley. McAda and Barroll (2002) used lower eastern mountain-front recharge values, and their results indicate flow parallel to the river.

\section{${ }^{14} \mathrm{C}$ Activities}

Ground-water travel times and activities of ${ }^{14} \mathrm{C}$ at wells were simulated using MODPATH and results from MODFLOW. Results for individual wells are given in table A3. Although ${ }^{14} \mathrm{C}$ activities were used as the simulated observations, the distribution of simulated ages is shown for layers 2 and 6 in figure 36, because such ages can often more intuitively reveal model behavior. The model ages are converted to simulated ${ }^{14} \mathrm{C}$ activities using equation 2 . The simulated ages 


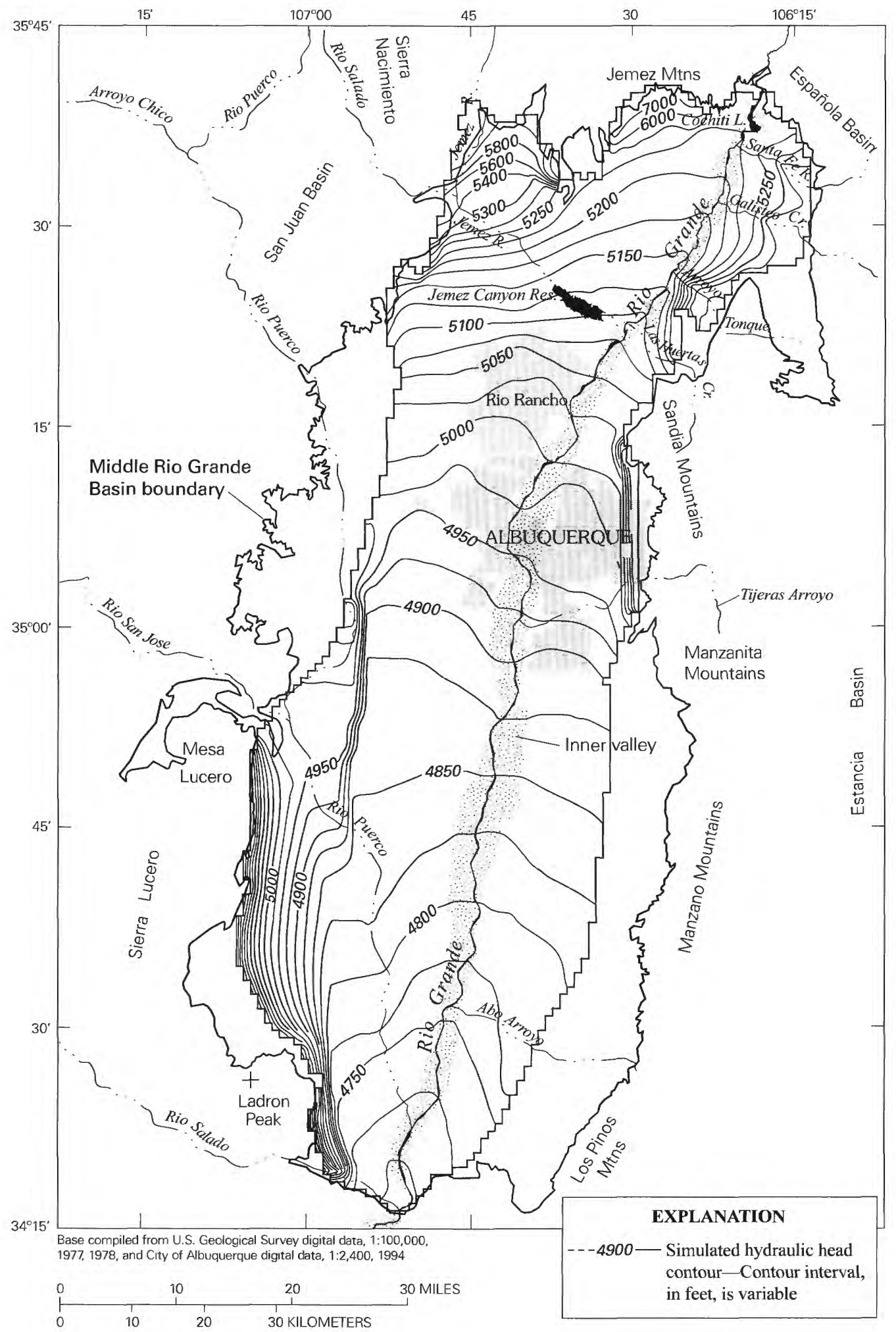

Figure 33. Simulated water levels in layer 2 of the steady-state ground-water-flow model. 


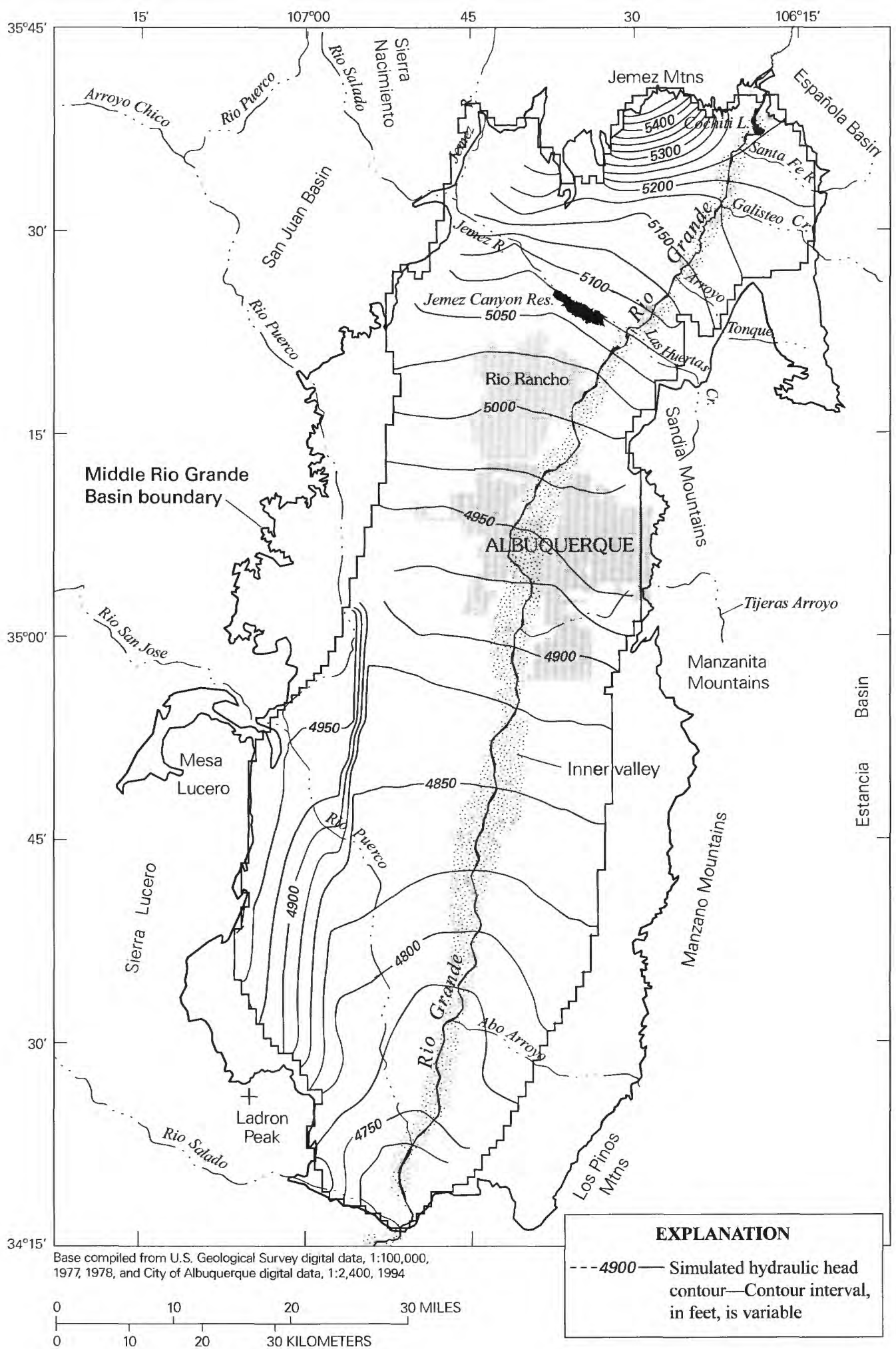

Figure 34. Simulated water levels in layer 6 of the steady-state ground-water-flow model. 


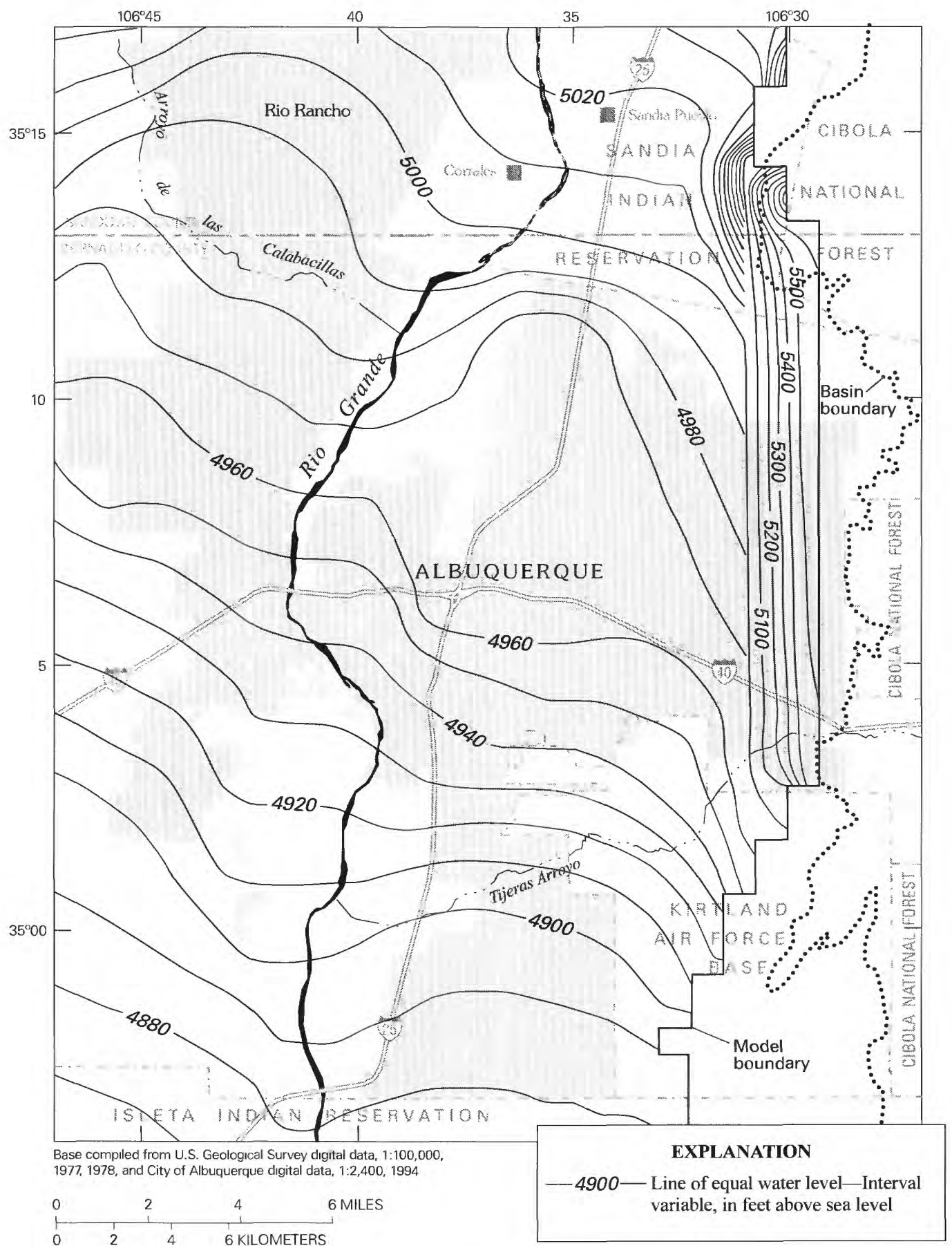

Figure 35. Simulated predevelpment water levels, in feet above sea level, in the vicinity of Albuquerque in layer 2 of the ground-water-flow model. 
were plotted by placing a 10 by 10 grid of particles in every model cell and tracking the path lines backward to the source location. For path lines that reached underflow boundaries, the basin-entrance ages (table 3 ) were added to the MODPATH travel times. The ages for the entire grid of particles was then plotted to produce the images in figure 36 . Several patterns emerge. Young water (less than 3,000 years) represented by the dark blue areas is present near the mountain fronts where recharge occurs at the land surface, and along the Rio Grande and Rio Puerco near where the rivers are losing water to the aquifer system. This general pattern mimics the pattern of ages observed in the basin (fig. 8). Older water represented by the yellow and red areas is present in the southern part of the basin and in areas next to basin boundaries where water is entering the basin as underflow. Very old water is also shown in the explicitly represented Cat Mesa Fault Zone because the flux inside that zone is so low that particles being tracked out require very long times.

A cross section of the simulated ages along row 75 is shown in figure 37. Although there is a general pattern of increasing simulated age with depth, the heterogeneity of the system in a few places creates local inversions where old water is predicted to occur above younger water that is moving through a more permeable zone. It should be noted that these ages are simulated using values of recharge that do not vary in time. Because some of the ages exceed 100,000 years, it is important to recognize that any variations in recharge over that time scale would give different age distributions for the aquifer system. The problem of time-varying recharge is addressed in the transient paleohydrologic simulation.

\section{Hydrochemical Zones}

The hydrochemical zones as identified by geochemical signatures (fig. 9) were also simulated using MODPATH and results from MODFLOW. The recharge regions were first divided into sections that roughly coincided with the areas identified as recharge sources by the geochemical signatures (table 1). MODPATH was then run in the same manner as for the creation of the age maps except that the source locations were plotted according to the starting locations of the particles. Results of the hydrochemical target-region observations are given at the end of table A3. A more complete map of source-delineation results is shown for layers 2 and 6 in figure 38. The final estimated model parameters reproduce all of the major zones identified in the geochemical survey. The red area in the center of figure 38 represents water that was recharge from the Rio Grande. This simulated zone is similar in total area to that of observed zone 12 (fig. 9), although the simulated zone extends farther into the center of the basin than the observed zone. One likely explanation is the steady-state assumption that recharge rates have been constant for more than 100,000 years. Water in the Rio Grande zone is about 10,000 years old at its western edge (figs. 8 and 9), suggesting this zone began forming after the climate change following the last glacial maximum. The fact that the western edge of the zone roughly parallels hydraulic-head contours within the city limits (figs. 4 and 9) also suggests this zone boundary may not have reached its potential farthest western extent from the Rio Grande. It is also possible that north-south-trending faults are partially blocking the movement of Rio Grande water farther west into the trough.

The earlier ground-water model of Kernodle and others (1995) did not predict the presence of any Rio Grande water in the aquifer system beyond the shallow system in the Inner valley under predevelopment conditions. This conclusion is not based on their model budget, which only records water leaving the Rio Grande itself, but on visual inspection of the simulated hydraulic heads (Kernodle and others, 1995, figs. 20 and 21). Tiedeman and others (1998) simulated several different hydrogeologic configurations to try to understand the origin of the trough and according to their model budgets, two of those configurations result in Rio Grande water leaving the Inner valley under predevelopment conditions. McAda and Barroll (2002) presented only one hydrogeologic configuration, but whether their model simulates Rio Grande water leaving the Inner valley is inconclusive based on their model budget or simulated predevelopment hydraulic-head map (their fig. 14). Source-area delineation mapping was not performed in any of the earlier modeling studies to show conclusively where Rio Grande water might have left the Inner valley.

The region of ground water that was simulated to come from the Rio Puerco also agrees with the geochemical survey, and the use of this area as an observation was important in the calibration of the amount of recharge estimated from the Rio Puerco. A cross section through row 75 of the simulated hydrochemical zones is shown in figure 37 . The east and west basin boundary waters tend to remain along those boundaries, but the Rio Grande water penetrates down to about 1 kilometer, and the northern underflow waters occupy the central, deeper section of the basin.

\section{Best-Fit Parameter Estimates}

The combination of automated nonlinear regression runs and manual parameter adjustments led to the final parameter list in table 3. The best-fit values are listed there along with the assigned values for those parameters that were not estimated. After automatic convergence was attained, each estimated parameter value was varied individually to identify the point of minimum global error. An entire sweep of the parameters in this manner was, in effect, one manual iteration. Not all parameters required adjustment during a manual iteration to attain the minimum error. Three manual iterations were performed in all, resulting in a lowering of the minimum global error by about 20 percent. The estimated parameter values and their linear 95 percent confidence intervals are shown in figures 39-41. These confidence intervals should be considered as rough indicators of the confidence in the parameter estimates because in addition to the nonlinearity of the model, there is model error associated with the locations of the boundaries and zones that are not taken into account in the confi- 


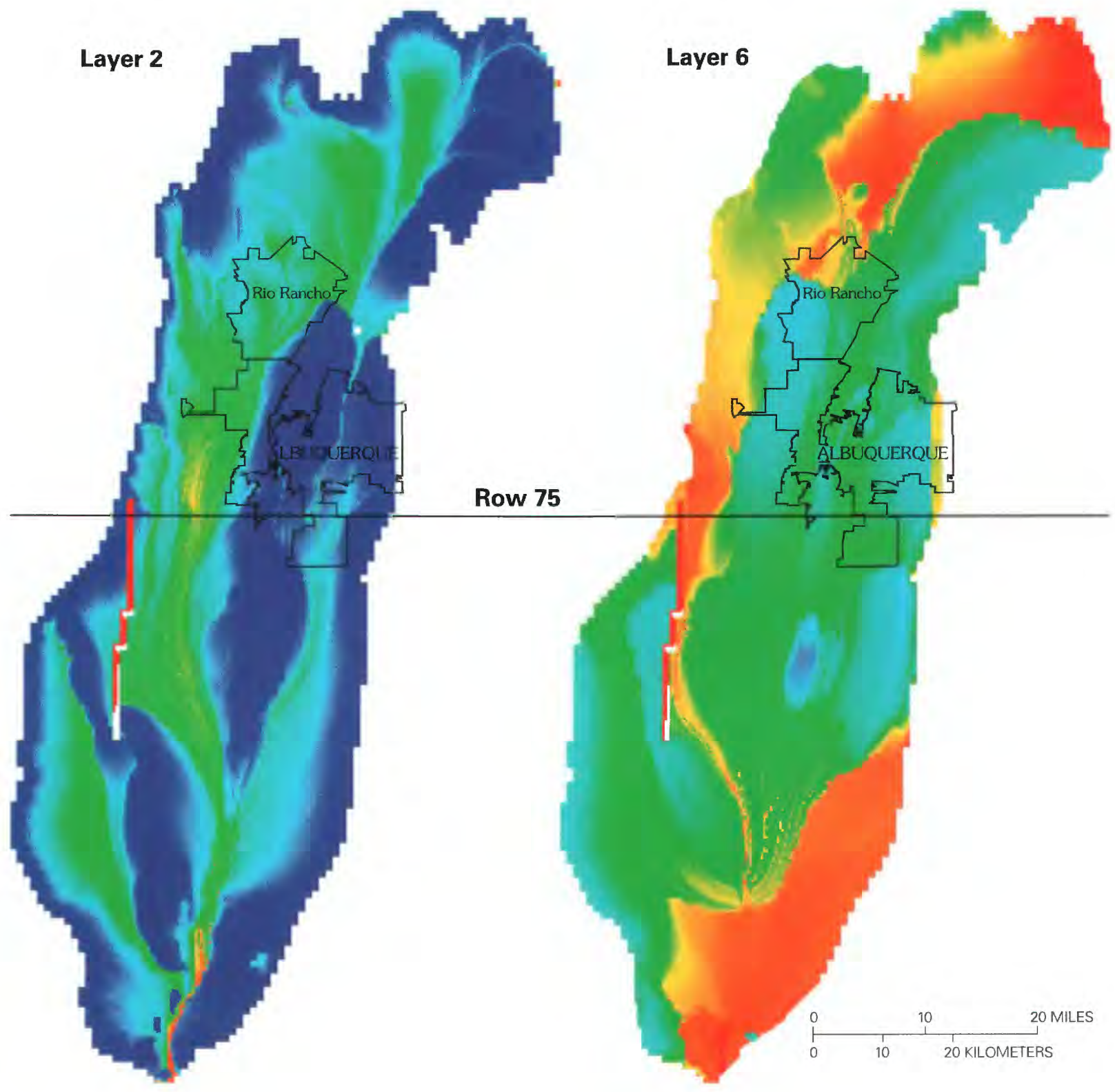

EXPLANATION

Simulated ground-water age, in log (years)

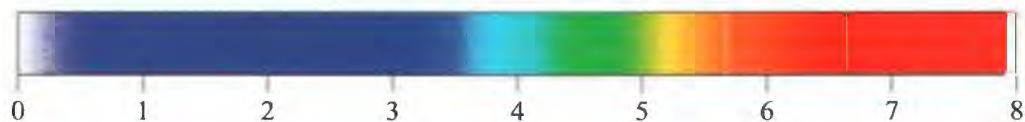

Figure 36. Simulated ground-water ages in layers 2 and 6 of the steady-state ground-water-flow model. 


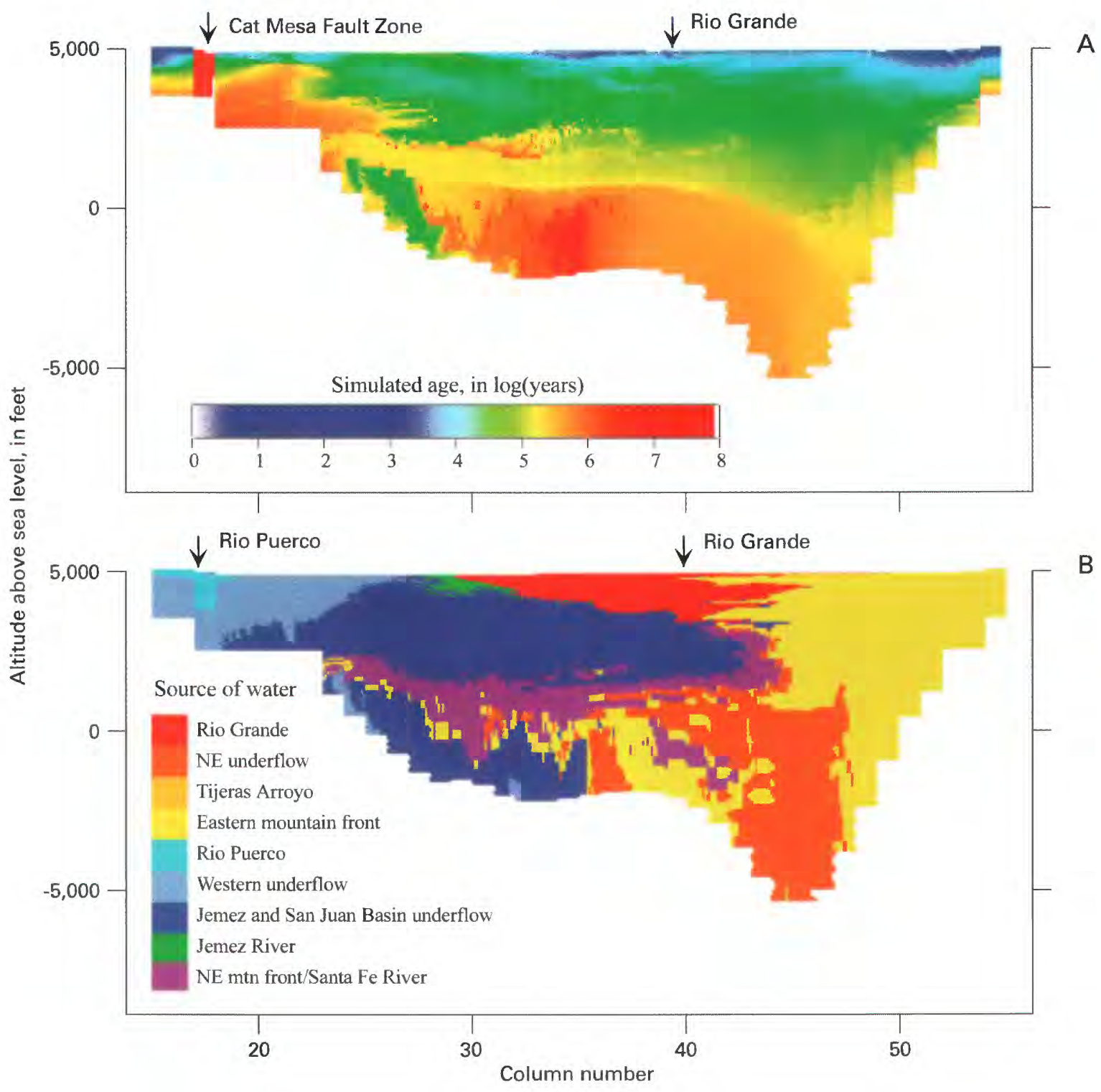

Figure 37. Simulated $(A)$ ground-water ages and $(B)$ source of water along row 75 of the steady-state ground-water-flow model (see fig. 36 for location of row 75).

dence interval calculations. The relative size of the interval in relation to other parameters is the most valuable information associated with the confidence interval calculations. A narrow band for the confidence interval indicates that, given the model is correct, the observed data provide more certainty that the estimated value is close to a true value, whereas a broad band indicates the available data cannot provide as much certainty. If there is likely model error (usually the case), then the interval more realistically represents the precision of the estimate, which is a function of how much information the observation data provide about the parameter value.

Uncertainty in the model parameters is also a function of parameter correlation. UCODE evaluates the correlation matrix during the sensitivity analysis. A correlation value of 1.0 or -1.0 indicates a perfect positive or negative correlation between parameters, respectively. A pair of such parameters is completely nonunique and indistinguishable. Similarly, correlation values of greater than 0.9 or less than -0.9 suggest strong correlation or nonuniqueness of parameters. Models dominated by head observations can typically have many highly correlated parameters (Poeter and Hill, 1997; Hill, 1998). Adding information to the model on advective path lines or travel times has been shown to reduce parameter correlation (Anderman and others, 1996; Poeter and Hill, 1997). For this model, the inclusion of travel times through the simulated ${ }^{14} \mathrm{C}$ activities resulted in a model with no highly correlated parameters. Out of 1,770 correlation values between parameters, only one value exceeded 0.8 and two values were less than -0.8 . Nearly 1,200 values were between -0.2 and 0.2 , indicating very little correlation. 


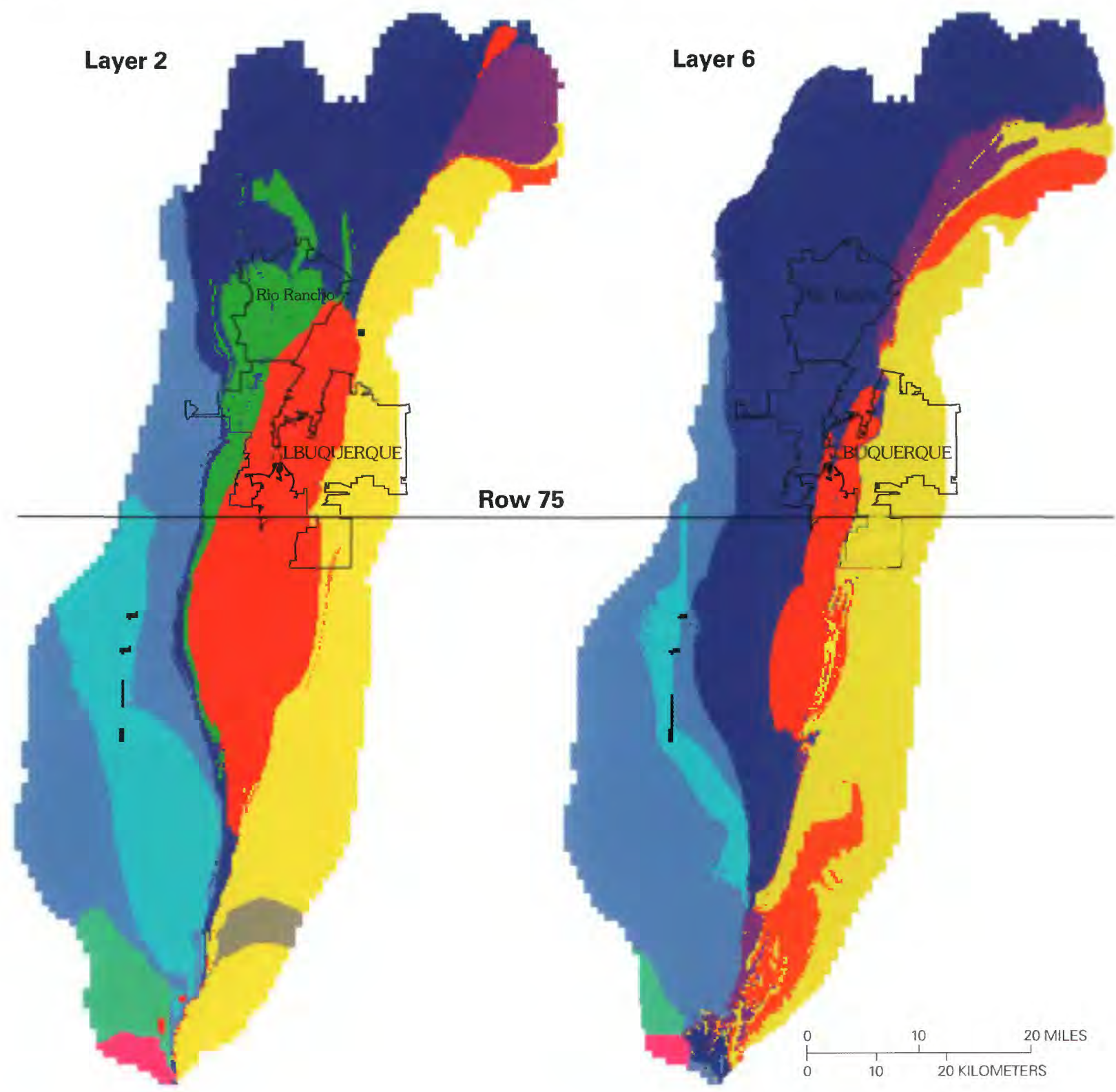

EXPLANATION

Simulated source of water within the basin
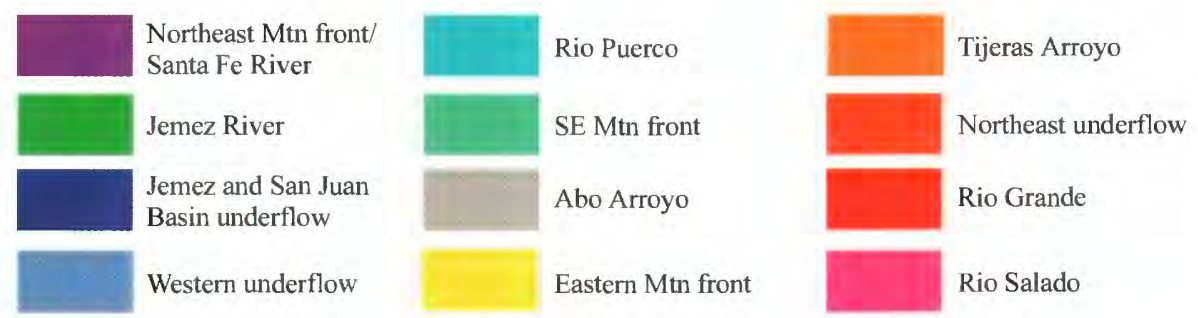

Figure 38. Simulated geochemical zones in layers 2 and 6 of the steady-state ground-water-flow model. 


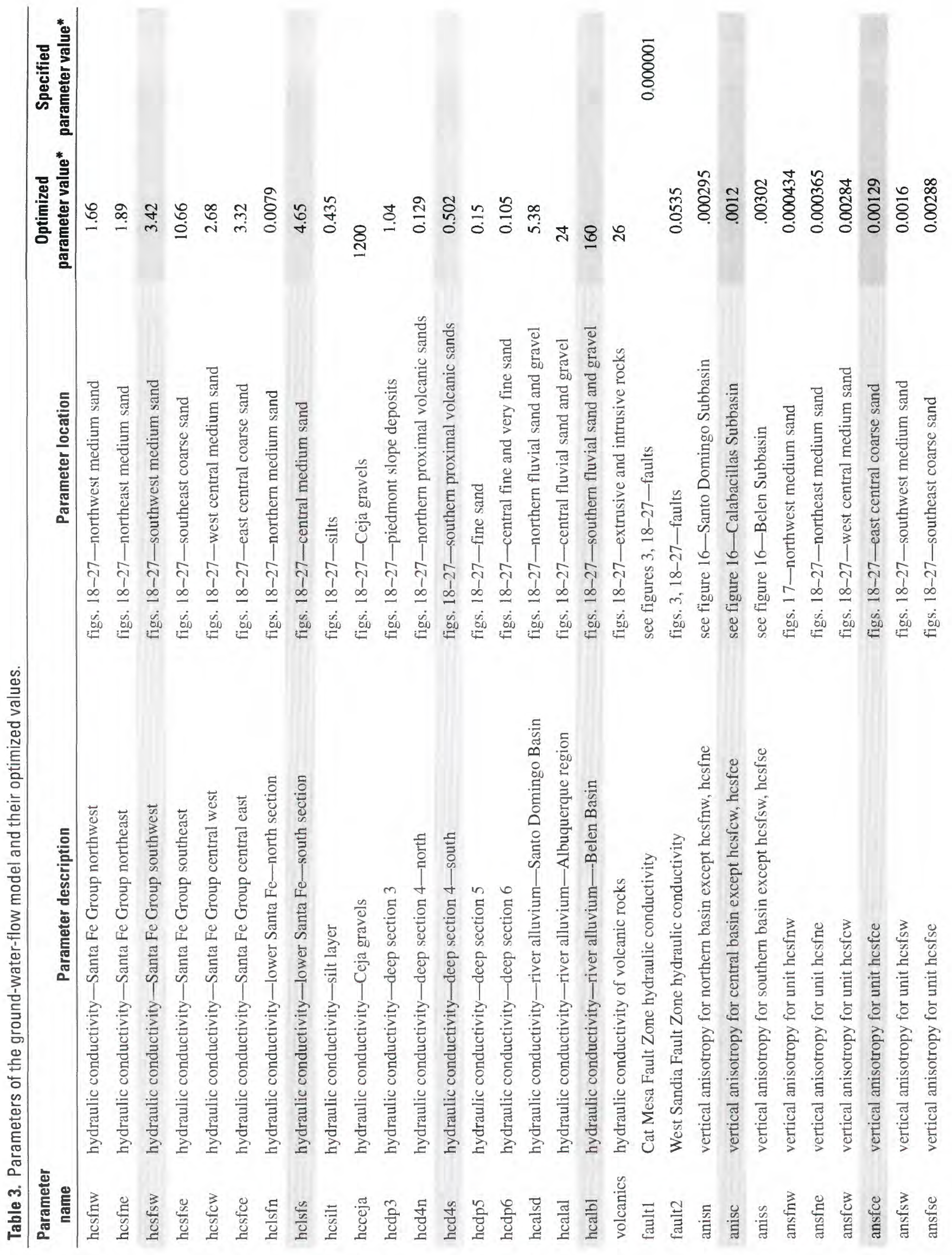




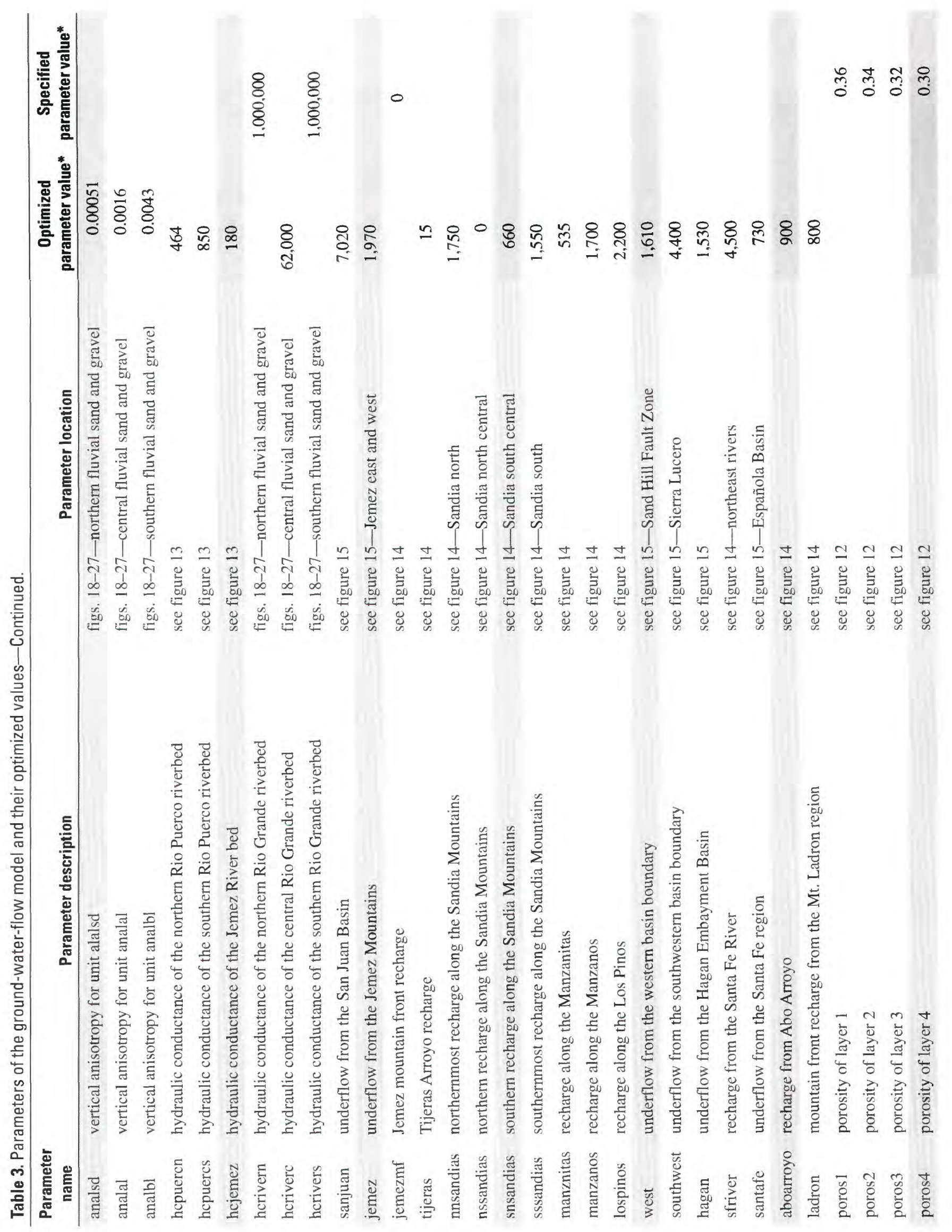




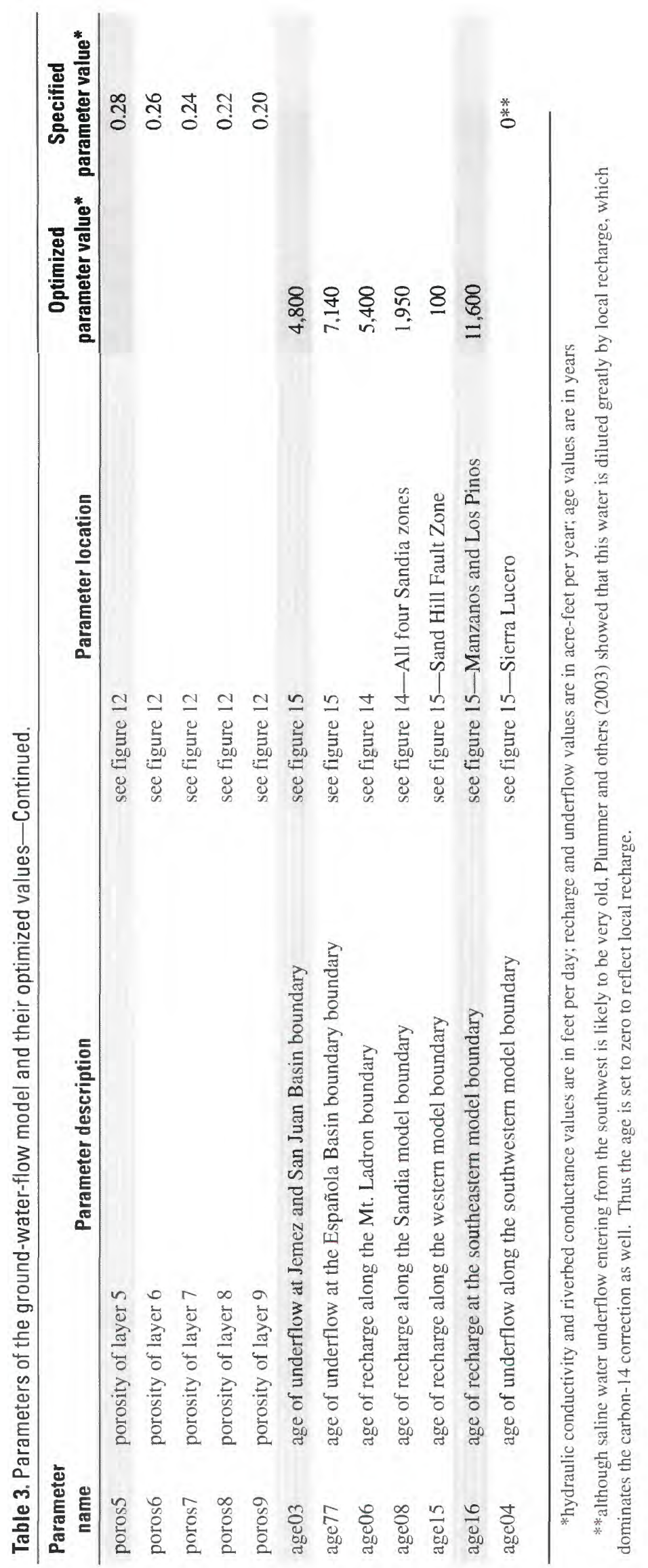




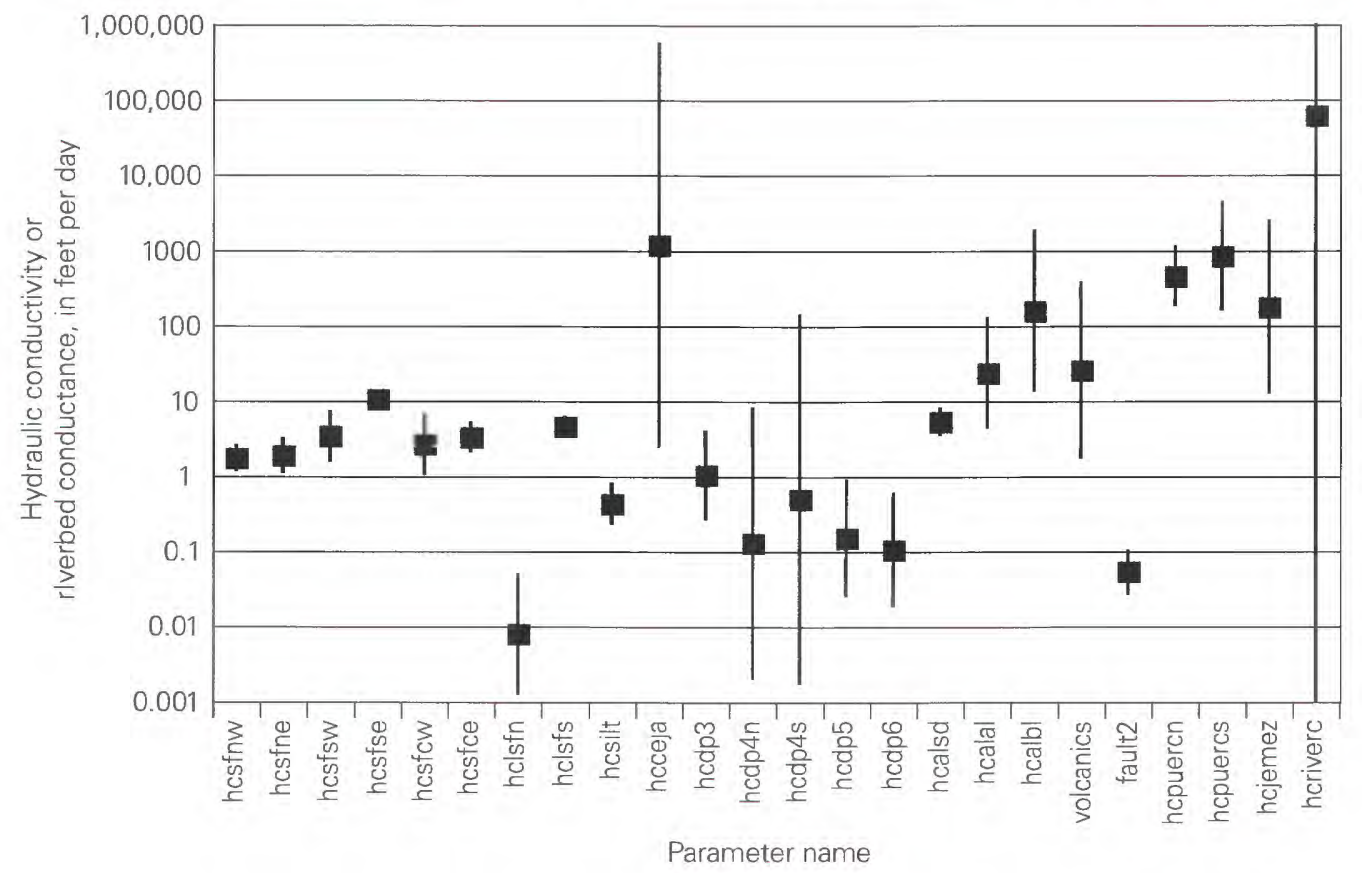

Figure 39. Optimized parameter values and 95 percent linear confidence intervals for hydraulic conductivity and riverbed conductance (see table 3 for parameter descriptions).

\section{Hydraulic Conductivities}

The estimated values for hydraulic conductivity and riverbed conductance are shown in figure 39 . Values for the hydraulic conductivities of the Santa Fe Group fall mostly between 1 and 10 feet per day with some exceptions. These are values that are similar to estimates from previous models (Kernodle and others, 1995; Tiedeman and others, 1998) and to prior field measurements concerning the basin fill material (Thorn and others, 1993). Zones that have estimated hydraulic conductivity values significantly less than 1 foot per day are (1) the deeper Santa Fe unit to the north; (2) the silt layer in the central basin; (3) the deep units 4, 5 and 6; and (4) the West Sandia Fault Zone. Zones that have estimated values significantly greater than 10 feet per day are (1) the Ceja gravels, (2) the volcanic rocks, and (3) the alluvium associated with the paleochannel of the Rio Grande in the central and southern basin. The best-fit value for the Ceja gravels of greater than 1,000 feet per day exceeds all known field measurements, but the model could not estimate this value with any reasonable precision. Values for the Ceja gravels that were assumed in earlier models ( 100 feet per day or less) are well within the broad linear confidence interval shown in figure 39. Other parameters with high uncertainty were all of the deep units and Rio Grande alluvium. The riverbed conductances also were associated with high degrees of uncertainty. Some validation for the parameter values estimated for this model is given by the fact that the silt layer and the volcanic rock units had estimated values (low and high, respectively) that agree with their relative expected values. A valuable result of this study was not only estimates of parameter values but their uncertain- ties that reflect the current state of available data. Because the objective of this study was to estimate parameter values, and not provide a final model for management use, parameters with high uncertainty, such as the Ceja gravels, were not reassigned more reasonable values.

The best-fit values estimated for the vertical anisotropy in the hydraulic conductivity of the basin are shown in figure 40. The anisotropy $\left(K_{v} / K_{h}\right)$ was estimated individually for 12 structural zones within the basin (fig. 16), and the values range from about 0.0003 to 0.004 . Originally only three anisotropy zones were used, but the simulated observations were quite sensitive to their values, so an additional nine zones were ultimately added. These values are consistent with what might be expected for a layered system where the individual layers are isotropic and have values that vary by 2 to 4 orders of magnitude. Certain layers such as the silt, gravel, and volcanic layers would be expected to have values that vary by more than this, but they have been accounted for explicitly in separate zones.

\section{Recharge Rates}

The best-fit values estimated for recharge rates and initial underflow ages to the basin are shown in figure 41. Recharge was not estimated directly for the Rio Puerco and the Jemez River, but only through their riverbed conductance values (fig. 39). These conductance values translate into 3,600 acre-feet per year for Rio Puerco, but only 160 acre-feet per year for the Jemez River (table 4). The recharge for the Rio Puerco was similar to values used in earlier models, but the Jemez River recharge value was very much lower. The recharge from the Jemez River in the current study was constrained by the 
observation of very old water just to the south of the Jemez River. It should be noted, however, that the confidence interval and therefore the uncertainty associated with this recharge estimate is very large. The model suggests that most of the ground water that originates outside the basin is coming from underflow from northern basins, at several thousand acre-feet per year.

Recharge from the eastern mountain front is estimated at about 8,500 acre-feet per year, with another 900 acre-feet per year leaking through Abo Arroyo. These numbers are somewhat lower than previous estimates that were based on rainfallrunoff equations, but are close to recent estimates of recharge along the eastern mountain front made using the chloride mass-balance method (Anderholm, 2001; table 4). Total recharge to the basin is estimated to be 55,000 acre-feet per year, with 20,000 acre-feet per year of the total coming from the floodplain of the Rio Grande. Kernodle and others (1995) showed Rio Grande leakage of 141,000 acre-feet per year, but most, if not all, of this is intercepted by evapotranspiration on the flood plain of the inner valley. Their model does not report a value leaving the inner valley, but visual inspection of their head contours strongly suggests this. The model of Tiedeman and others (1998) shows ground water leaving the inner valley, but only with certain hydrogeologic configurations of the ground-water trough. McAda and Barroll (2002) do not give estimates of ground-water fluxes leaving the inner valley, nor does a visual inspection of their hydraulic head map reveal whether ground water is leaving the inner valley. The basinmargin recharge estimated from this model, 35,000 acre-feet per year, is one-fourth of the estimates used in Kernodle and others (1995), and about half of that of McAda and Barroll (2002). The estimate for recharge from Tijeras Arroyo was very small ( 15 acre-feet per year), but the upper 95 percent linear confidence interval was 265 acre-feet per year. Some of the estimates for underflow recharge rates were accompanied with high uncertainty (very large confidence intervals).

\section{Ages at Model Boundaries}

Because it was difficult to obtain independent information on the age of ground water that enters the basin at different underflow boundaries, an attempt was made to estimate the ages at these boundaries in the parameter estimation procedure. Results of the estimates are given in figure 41. Most of the estimated values are accompanied by high uncertainty and broad confidence intervals. This indicates that the model could not estimate these values with any high degree of precision based on the data supplied. However, low sensitivity also indicates that the model error was not greatly affected by the value of the ages that were assigned at the boundary. This means that although the age at the boundary is a requirement in calculating travel times in the basin and underflow estimates, uncertainty in that age does not necessarily translate into greater uncertainty in the underflow estimates.

\section{Model Fit}

The overall goodness of fit of the model to the observation data was evaluated using summary measures and graphi-

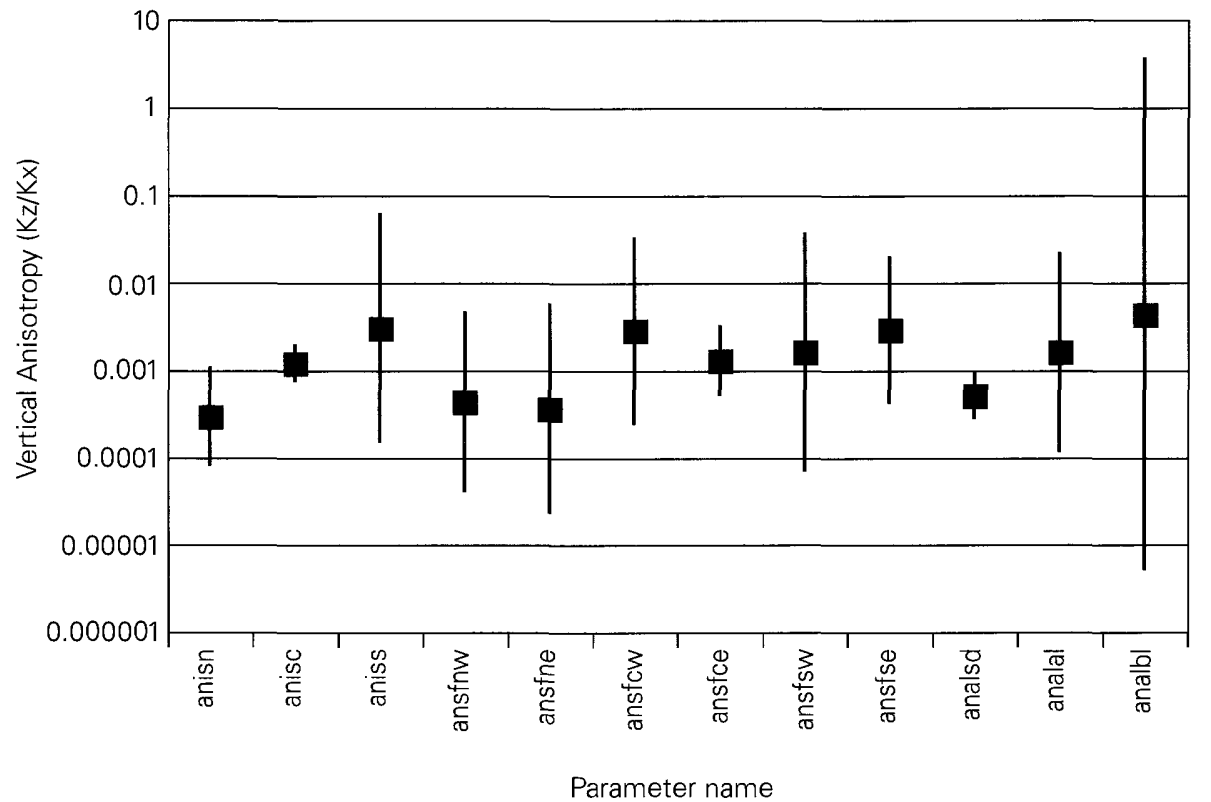

Figure 40. Optimized parameter values and 95 percent linear confidence intervals for anisotropy (see table 3 for parameter descriptions). 


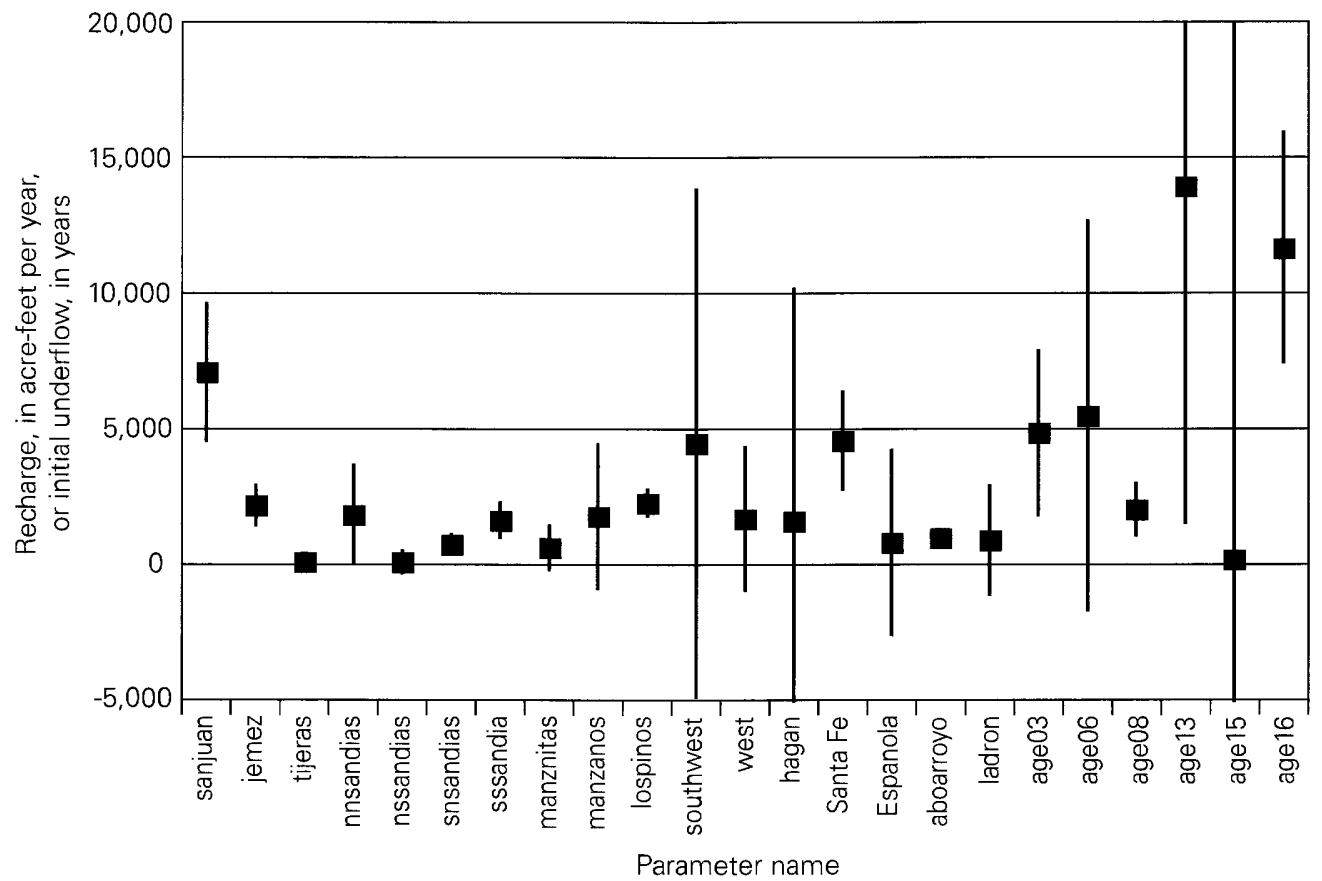

Figure 41. Optimized parameter values and 95 percent linear confidence intervals for recharge and initial underflow ages (see table 3 for parameter descriptions).

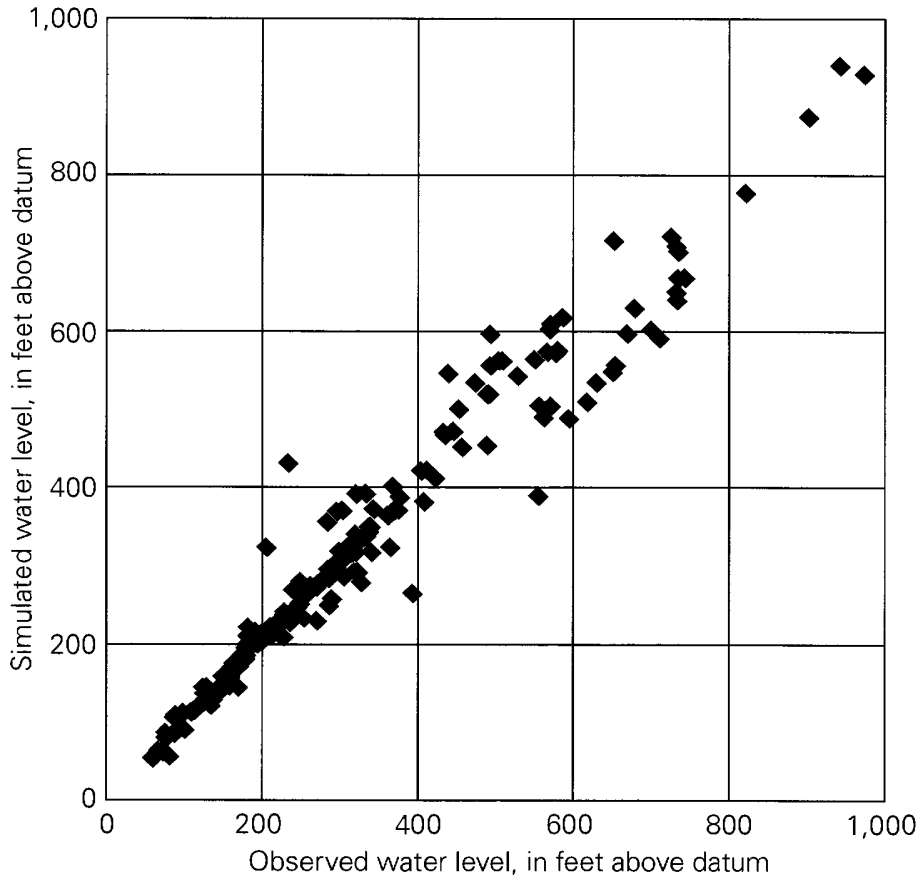

Figure 42. Observed water levels plotted against simulated water levels. Datum equals 4,650 feet above sea level.

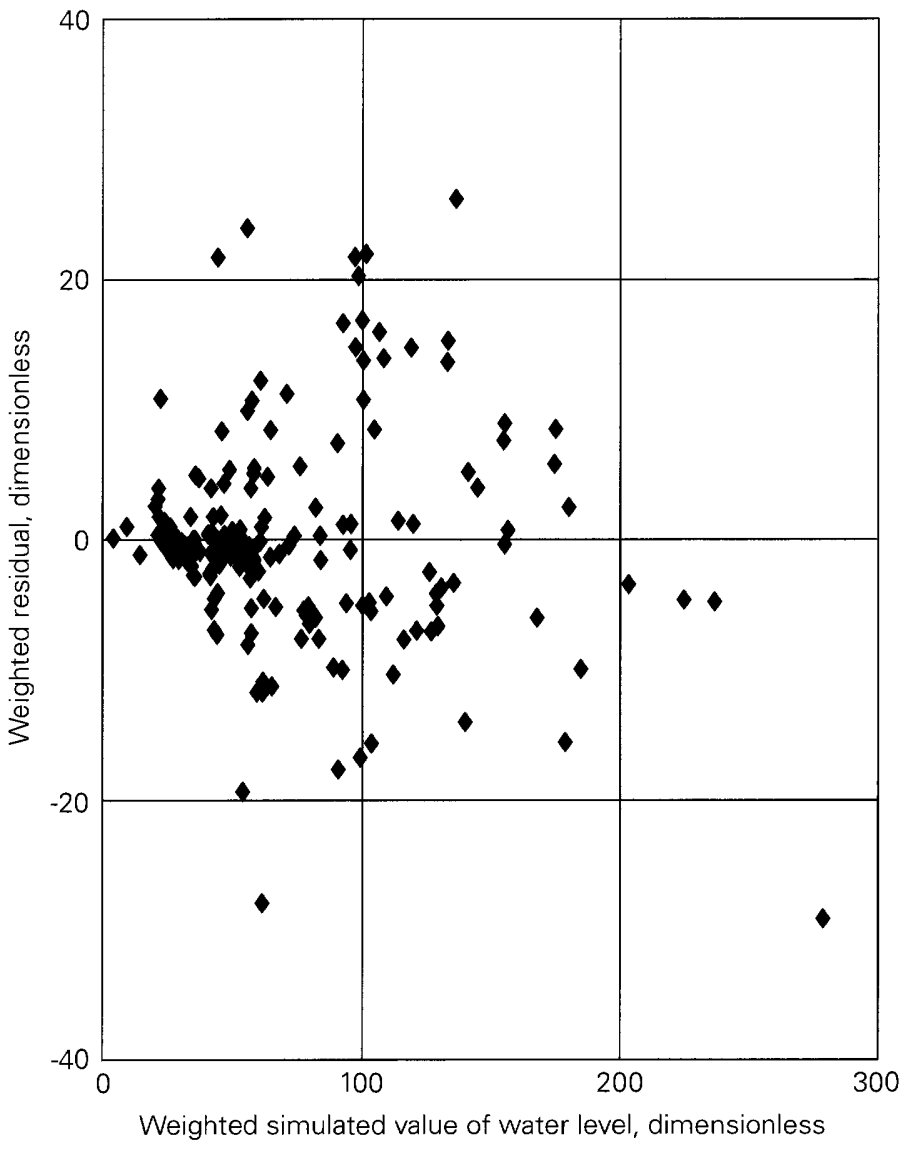

Figure 43. Weighted simulated values of water levels plotted against weighted residuals. 
Table 4. Estimates of inflow and outflow from the Middle Rio Grande Basin from recent studies.

[All values are in acre-feet per year. $\mathrm{nd}=$ not determined, $\mathrm{nr}=$ not reported]

\begin{tabular}{|c|c|c|c|c|c|}
\hline Region & $\begin{array}{c}\text { Kernodle } \\
\text { and } \\
\text { others } \\
(1995)\end{array}$ & $\begin{array}{c}\text { Tiedeman } \\
\text { and } \\
\text { others } \\
(1998)\end{array}$ & $\begin{array}{l}\text { Anderholm } \\
\text { (2001) }\end{array}$ & $\begin{array}{l}\text { McAda } \\
\text { and } \\
\text { Barroll } \\
(2002)\end{array}$ & $\begin{array}{l}\text { This } \\
\text { study }\end{array}$ \\
\hline \multicolumn{6}{|l|}{ Inflows to the Middle Rio Grande Basin } \\
\hline \multicolumn{6}{|l|}{ Inflows from external sources } \\
\hline \multicolumn{6}{|l|}{ Adjacent basin underflows (fig. 15): } \\
\hline Jemez West and East & 14,300 & 7,000 & nd & 14,900 & 2,000 \\
\hline Western Boundary & 4,700 & 4,700 & nd & 1,700 & 1,600 \\
\hline Southwest Boundary & 7,500 & 2,400 & nd & 900 & 4,400 \\
\hline San Juan Basin & 1,200 & 1,200 & nd & 1,000 & 7,000 \\
\hline Española Basin & 6,000 & 12,600 & nd & 14,000 & 1,500 \\
\hline Total underflows & 33,700 & 27,900 & nd & 32,500 & 16,500 \\
\hline \multicolumn{6}{|c|}{ Mountain front and tributary recharge (fig. 14): } \\
\hline Northeast Rivers (Santa Fe) & 7,600 & 7,700 & nd & 5,300 & 4,500 \\
\hline Tijeras Arroyo & 10,600 & 6,200 & 1,800 & 700 & $15 *$ \\
\hline Abo Arroyo & 15,400 & 15,400 & 1,300 & 1,300 & 900 \\
\hline Rio Puerco & 5,600 & 1,700 & nd & 1,000 & 3,600 \\
\hline Jemez River & 12,300 & 9,100 & nd & $15,000 * *$ & 200 \\
\hline Rio Salado & 7,200 & 7,200 & nd & 2,000 & 1,600 \\
\hline Sandia Mtn front & 19,500 & 11,500 & 4,200 & 5,500 & 4,000 \\
\hline Southeast Mtn front & 26,700 & 8,800 & 4,900 & 4,200 & 4,400 \\
\hline Total mtn. front and tributary recharge & 104,900 & 67,600 & nd & 35,000 & 19,200 \\
\hline Total recharge from external sources & 138,600 & 95,500 & nd & 67,500 & 35,700 \\
\hline \multicolumn{6}{|l|}{ Inflows from internal sources } \\
\hline Inner Valley (Rio Grande flood plain) & nd & $75,000 * * *$ & nd & nd & 20,000 \\
\hline Rio Grande & 141,000 & $\mathrm{nr}$ & nd & $63,000^{* *}$ & nd \\
\hline Total recharge from internal sources & 141,000 & $75,000 * * *$ & & $63,000 * *$ & 20,000 \\
\hline Total inflow to the MRGB & 279,600 & 170,500 & nd & 130,500 & 55,700 \\
\hline \multicolumn{6}{|l|}{ Outflows from the Middle Rio Grande Basin } \\
\hline Total Inner Valley (Rio Grande flood plain) & nd & $\mathrm{nr}$ & nd & nd & 55,700 \\
\hline Rio Grande & 8,000 & $\mathrm{nr}$ & nd & nd & nd \\
\hline Evapotranspiration & 261,000 & 170,000 & nd & 129,000 & nd \\
\hline Total outflow from the MRGB & 269,000 & 170,000 & nd & 129,000 & 55,700 \\
\hline
\end{tabular}

*Does not include the adjacent mountain front.

**Includes the Jemez Canyon Reservoir or Cochiti Lake.

$* * *$ Includes canals and drains in the lnner Valley. 
cal analyses. The standard error of regression is a measure of overall model fit to the calibration data, and is calculated as:

$$
S=\left(\frac{\mathrm{S}}{\mathrm{n}-\mathrm{p}}\right)^{\frac{1}{2}}
$$

where $S$ is the sum of the squared weighted residuals, $n$ is the number of observations, and $\mathrm{p}$ is the number of parameters. A standard error of regression greater than one is an indication of model error, given that the weights correctly reflect the measurement errors (Hill, 1998, p. 18). For this model, the final sum of squared weighted residuals was 77,000 , the number of observations was 409 , and the number of parameters was 60 , yielding a standard error of regression of 15 . This number is significantly larger than 1 , indicating model error, but given the complexity of the Middle Rio Grande Basin, this was expected. Only one model for the basin was calibrated in this study, so a value of $s=15$ cannot be compared to other models of the basin that were calibrated with the same data set. Earlier models of the basin by Tiedeman and others (1998) gave standard errors of regression between 3.4 to 4.0 . The total error in the model for this current study was distributed as 72 percent to the ${ }^{14} \mathrm{C}$ activities, 15 percent to the water levels, and 13 percent to the hydrochemical-target regions. Thus, most of the error for this model was in the matching of the ${ }^{14} \mathrm{C}$ activities. The earlier models were calibrated against mostly waterlevel data, and thus a better model fit would be expected under those conditions.

One of the simplest ways of assessing model fit is to plot the observations against the simulated observations. For a perfect fit, all points should fall on the 1:1 diagonal line. The water-level observations for the model were plotted in this way (fig. 42), and show a strong trend along the 1:1 line. Another way to assess model fit and model bias is to plot the weighted residuals against the weighted simulated values. Ideally, these points should show a random distribution above and below zero for all weighted simulated values, indicating a lack of bias in the model error. The water-level residuals and simulated values were plotted in this way also (fig. 43), and show a random distribution above and below. Plots were also made of the ${ }^{14} \mathrm{C}$ observations to assess model fit and error. Observations plotted against simulated observations (fig. 44) show a substantially greater amount of scatter about the 1:1 line than the water-level observations. This poorer fit to the ${ }^{1+} \mathrm{C}$ data was expected. Water levels represent a smoothly varying potential field that can be fit without much difficulty to the solution of the flow equation. Ground-water ages are a function of velocities that are in turn a function of the first derivatives of the ground-water-potential field, and are thus more difficult to fit. In addition, the multiple source areas in the Middle Rio Grande Basin create age patterns within the basin that are discontinuous (fig. 36), increasing further the complexity and difficulty in fitting age-related simulations to observations. Weighted residuals plotted against weighted simulated values for ${ }^{14} \mathrm{C}$ activities (fig. 45) show a similar number of values above and below the zero-residual line. The distribution, however, is not random because there are sloping envelopes within which the data must lie. The envelopes are present because the observations cannot lie outside of the range of $0-100$ percent modern carbon.

A more detailed comparison of model fit to the data is accomplished through analysis of the spatial distribution of the water-level and ${ }^{14} \mathrm{C}$ activities residuals and weighted residuals. The water-level residuals and weighted residuals are plotted over a map of the Middle Rio Grande Basin to ascertain the regions of the basin where the model fit is good or poor (figs. $46,47)$. The weighted residual plot shows the errors adjusted for the certainty in the observational data. In both cases it can be seen that the better fits to the data are in the center of the basin and along the Rio Grande. This is expected somewhat in that the Rio Grande acts as a line of constant head from which the head solution is not allowed to deviate substantially. The poorest matches to water levels occur in the northern section of the basin. Simulated water levels were consistently too low near the Jemez River and extreme northeast section of the basin, and too high in the Rio Rancho and northeast sections of the basin. The observed ground-water trough appears to extend farther north into the Rio Rancho region (fig. 4) than the current model simulates. Tiedeman and others (1998) also showed a poorer fit in the northern section of the basin. McAda and Barroll (2002) have similar magnitudes of residuals as this current model in the northern basin. This suggests that the hydrogeologic features in the north are different from those of the rest of the basin, and these differences are not included in the current models. To better simulate the northern section of the basin, a more regional model with a better representation of the hydrogeology may be required along with additional observation data.

The ${ }^{14} \mathrm{C}$ activities residuals and weighted residuals were also plotted over a map of the Middle Rio Grande Basin (figs. 48,49 ). These plots show less spatial bias in the error than the water-level residual plots show. One apparent pattern is that near recharge areas, the simulated activities are often too large (simulated ages are too young), whereas in the center of the basin the simulated activities are often too small (simulated ages are too old). This may suggest ground-water flow through the basin was slower sometime in the recent past, but faster in the more distant past. This idea of a varying flux, or recharge, in the past is investigated further in the transient paleorecharge simulation.

\section{Transient Paleorecharge Simulation}

A transient ground-water-flow simulation was performed to investigate the effect of time-varying recharge rates over the past tens of thousands of years on simulated ${ }^{14} \mathrm{C}$ activities. A 30,000 -year simulation was run using twelve 2,500 -year time steps preceded by a near-steady-state condition. The nearsteady-state condition was approximated by a 10 -million-year time step. This long initial time step allowed MODPATH to 


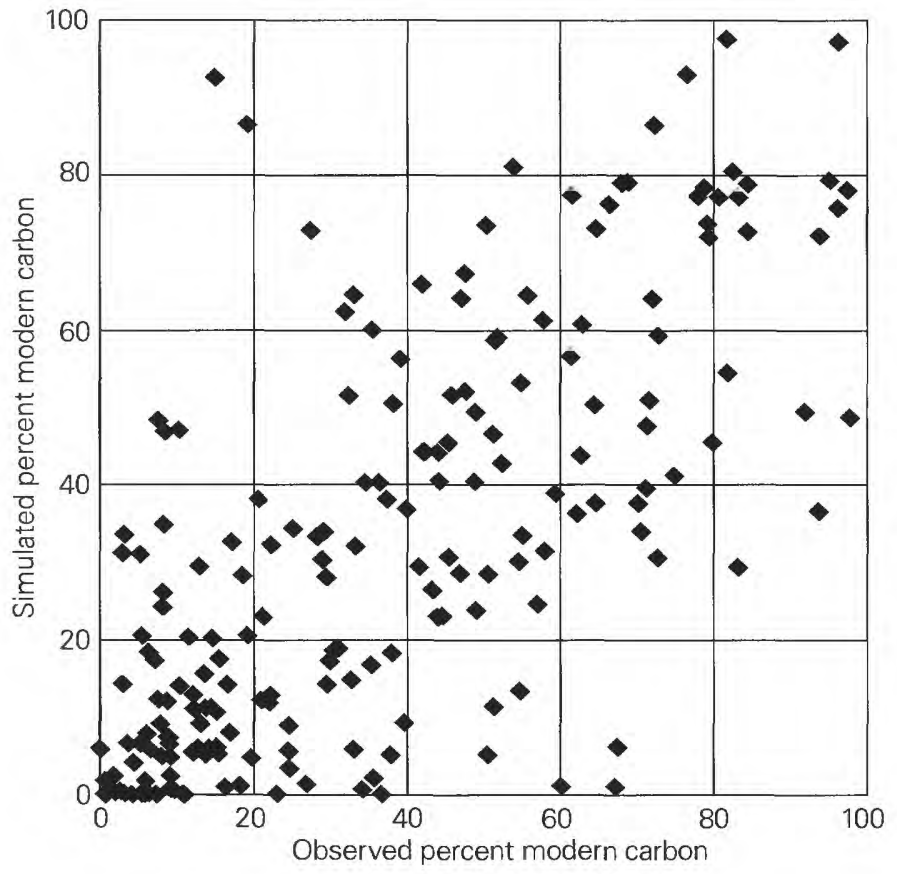

Figure 44. Observed plotted against simulated percent modern carbon.

track path lines back to recharge locations for path lines with very long travel times. Including the initial long time step, a total of 13 time steps were used. During each of the time steps, all recharge and underflow boundary cells were multiplied by a single recharge multiplier. The multipliers were all given an initial value of 1.0 to reproduce the conditions in the steady-state predevelopment simulation. The multipliers were then adjusted until an optimum fit was obtained between the observed data and the simulated observations. The nonlinear regression routine in UCODE was used initially to reduce the total sum of the squared errors, but eventually the individual recharge parameters were adjusted manually to obtain the best-fit recharge multiplier values. Results from this model were not used to report parameter estimates because none of the parameter estimates also in the predevelopment model changed during this simulation.

Results from the transient simulation suggest that recharge was greater before 15,000 years ago (fig. 50 ). The best-fit values for the recharge multipliers are greater than 10 for the period from 20,000 to 22,500 years ago. This time corresponds to the last glacial maximum that occurredapproximately 21,500 years ago. Evidence for a wetter climate during this period is also present in the Estancia Basin, just east of the Sandia Mountains, in the form of playa lake deposits (Bachhuber, 1992; Allen and Anderson, 2000). Simi-larly increased recharge during this time period is suggested from $14 \mathrm{C}$ flow-modeling and chloride results to the west in northeastern Arizona (Zhu, 2000; Zhu and others, 2003). The recharge multipliers have a best-fit value of 1.0 for the past 10,000 years, but have a value of 0.5 about 15,000 years ago. Although the relative changes in recharge rates are suggested by the transient simulation, the uncertainties associated with the values are quite high-especially the values before 20,000 years ago. An earlier simulation (Sanford and others, 2001) with longer time steps suggested that recharge during the glacial maximum was about five or six times greater than today. Some of the estimated increase in paleorecharge may be an artifact of not accounting for the vertical dispersion of ${ }^{14} \mathrm{C}$ in the basin as it is transported through the basin. This would have the effect of making deep water with small quantities of ${ }^{14} \mathrm{C}$ look younger than it really is, and the parameter estimation procedure would increase paleorecharge to account for this. In spite of this, all of the different results suggest greater recharge during the last glacial maximum and slightly less recharge just before or at the beginning of the Holocene. The exact amount of these changes in recharge, however, remains uncertain.

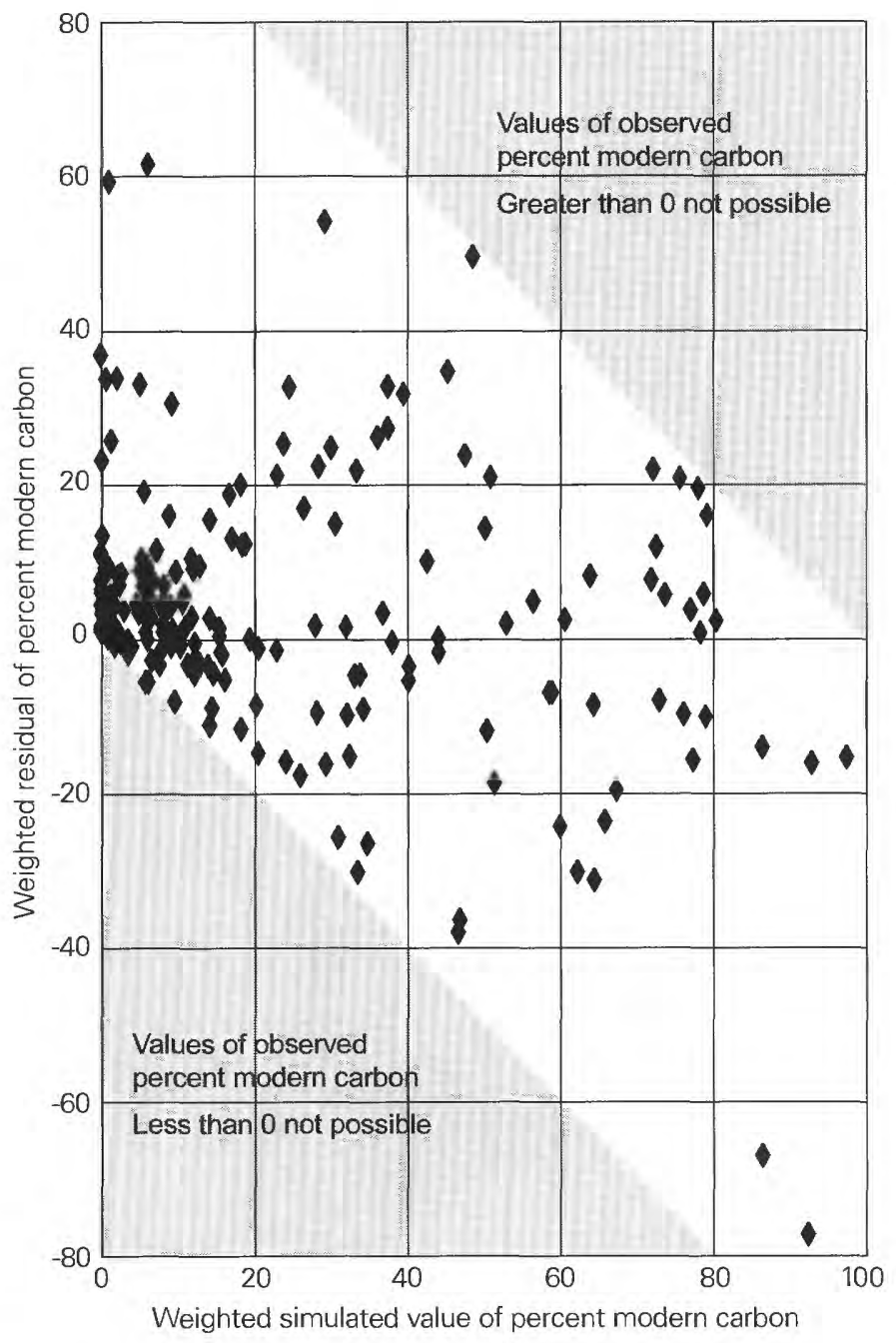

Figure 45. Weighted simulated values of percent modern carbon plotted against weighted residuals. 

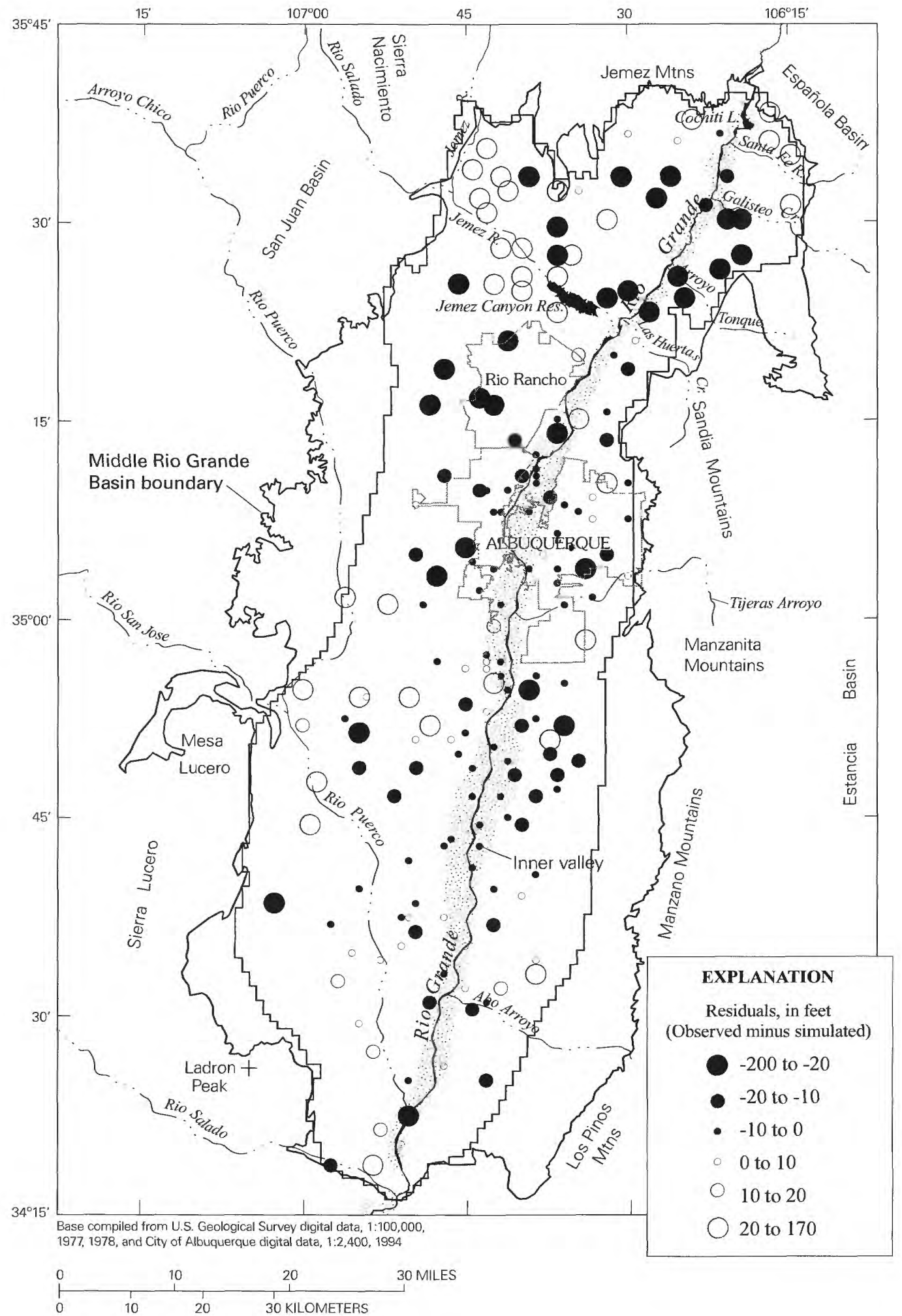

Figure 46. Spatial distribution of residuals between the observed and simulated water levels. 

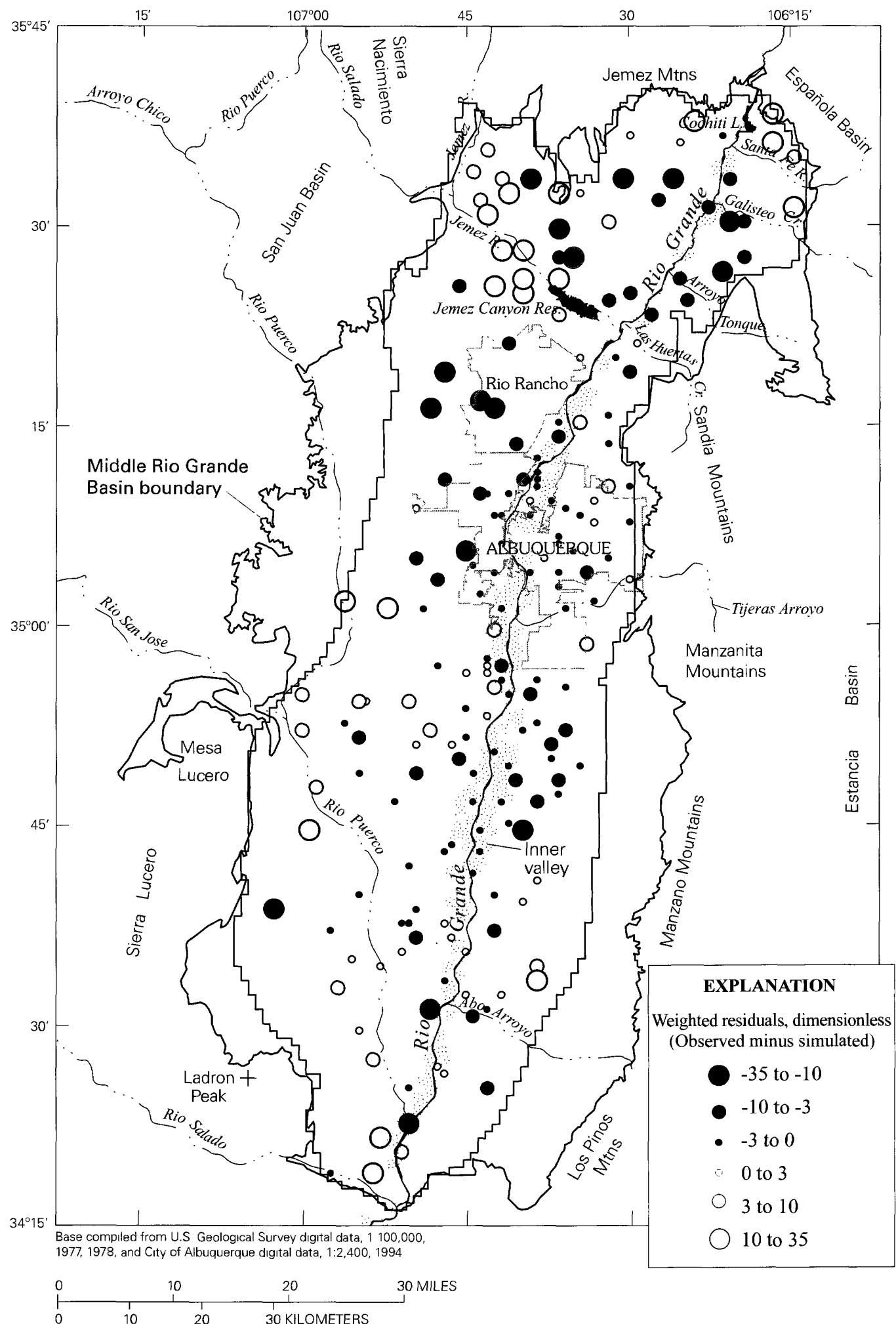

Figure 47. Spatial distribution of weighted residuals between the observed and simulated water levels. 

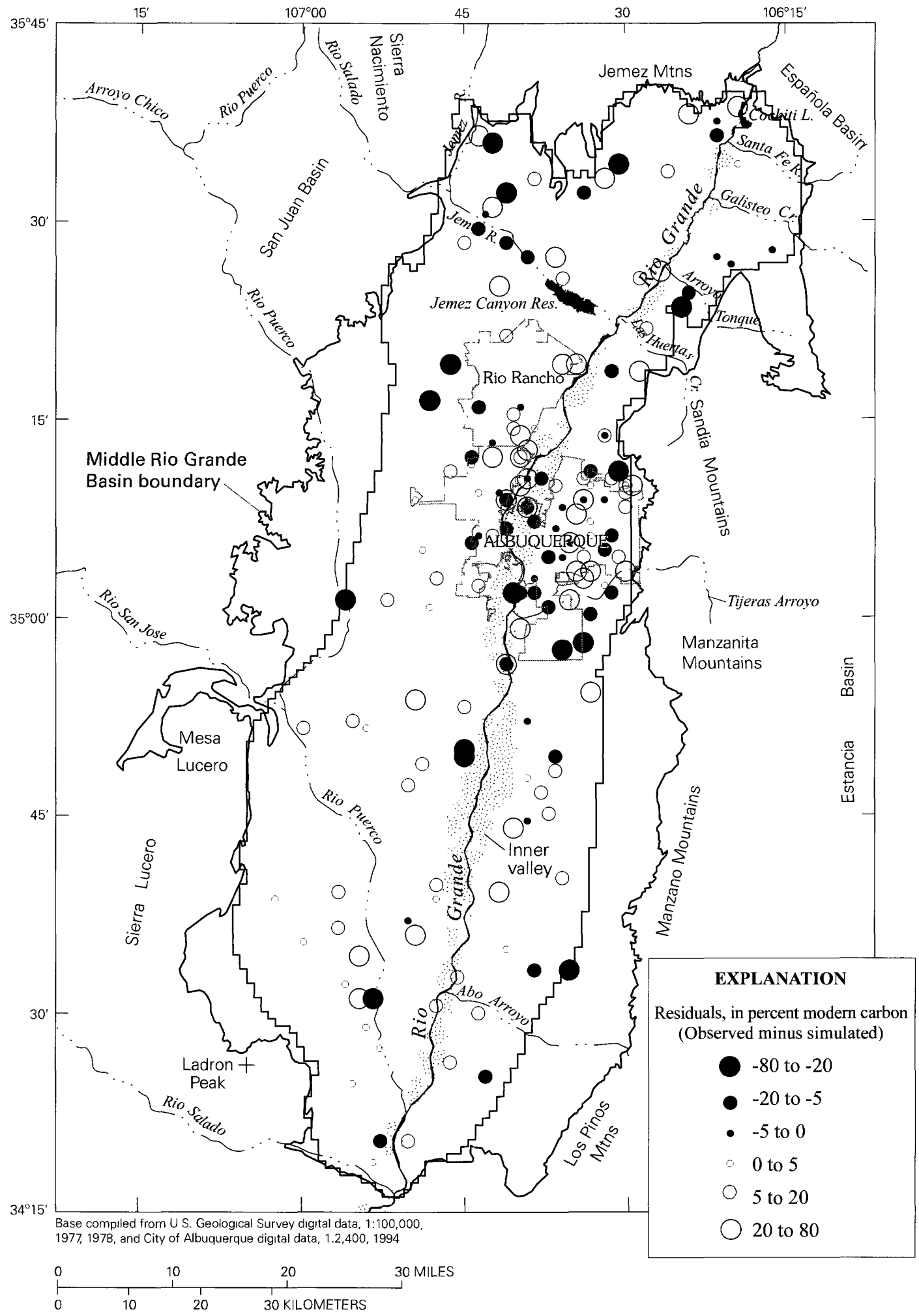

Figure 48. Spatial distribution of residuals between the observed and simulated ${ }^{14} \mathrm{C}$ activities. 


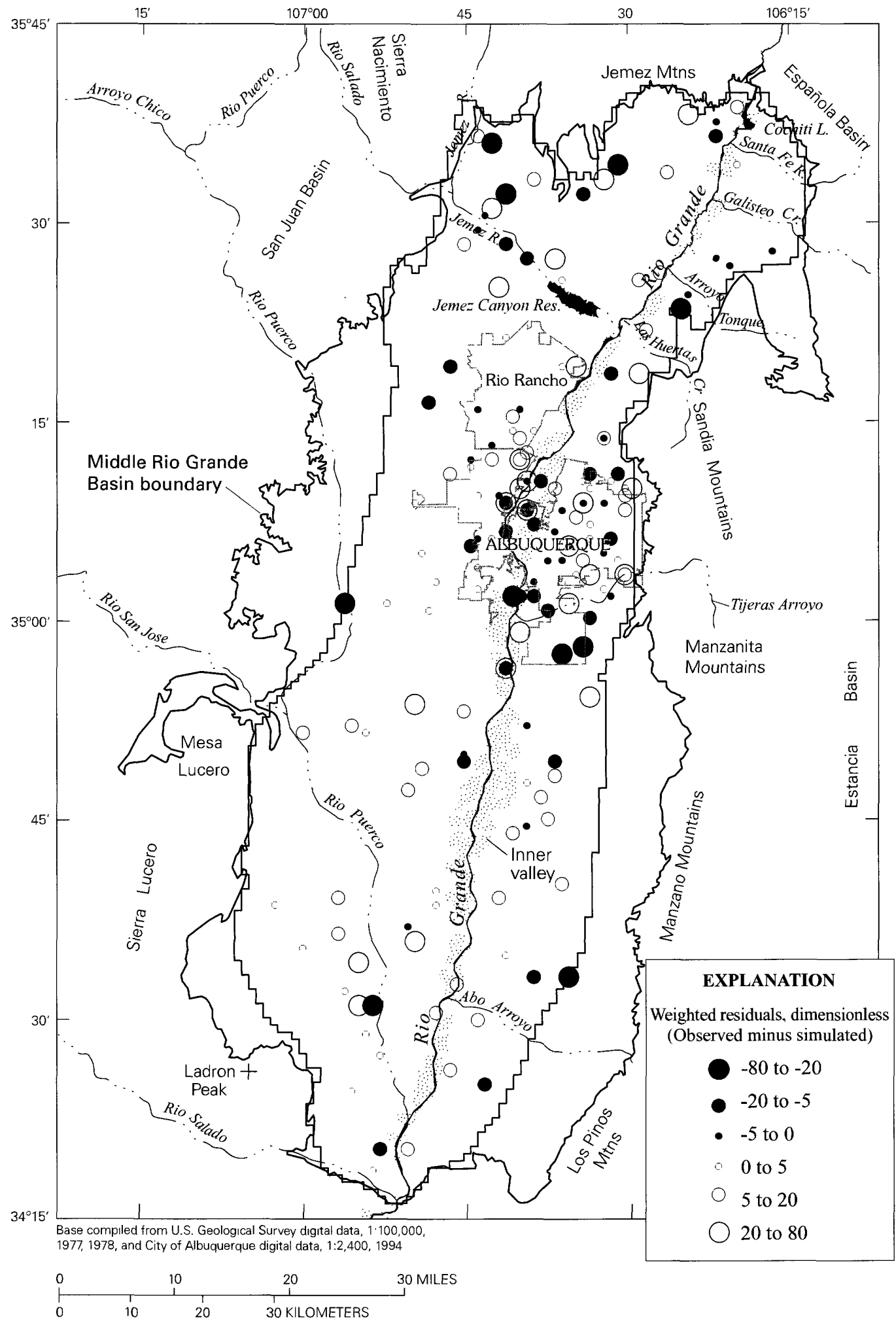

Figure 49. Spatial distribution of weighted residuals between the observed and simulated ${ }^{14} \mathrm{C}$ activities. 


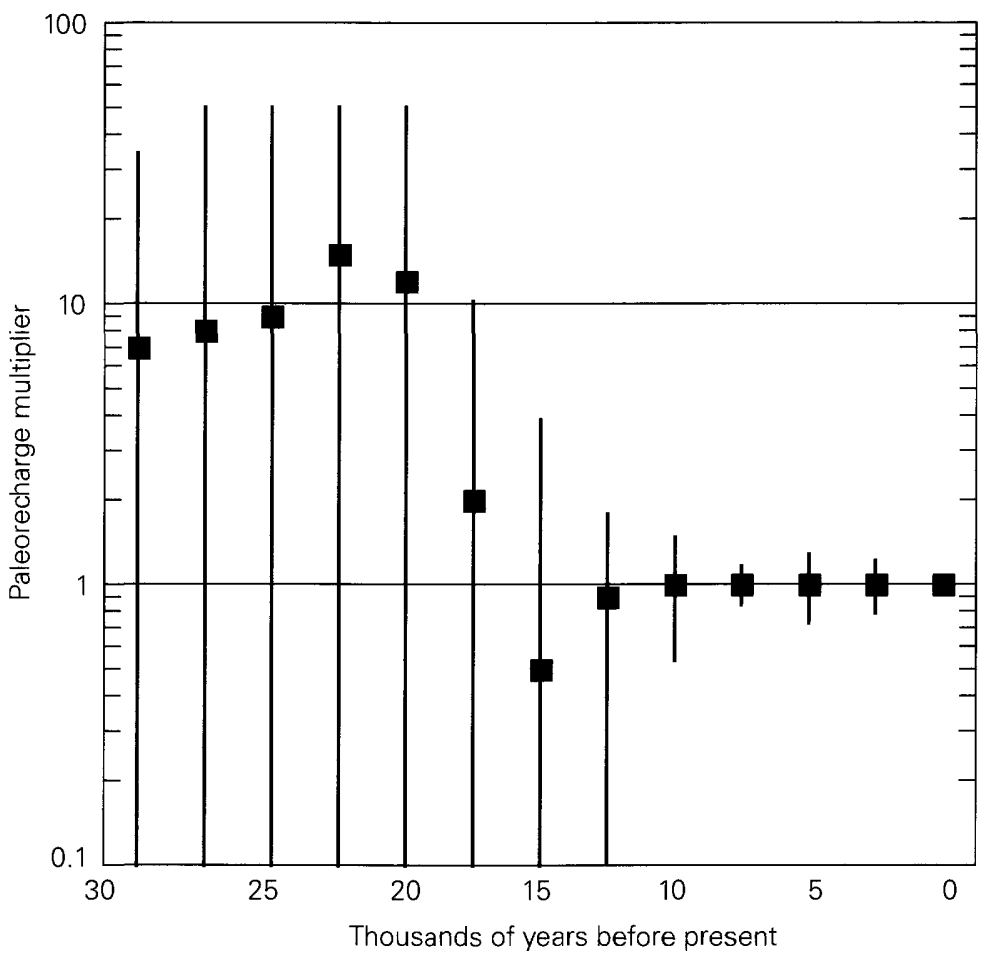

Figure 50. Optimized values of paleorecharge multipliers and their 95 percent linear confidence intervals.

\section{SUMMARY AND CONCLUSIONS}

The question of the availability of ground water as a long-term resource in the Middle Rio Grande Basin of central New Mexico was addressed recently by the characterization of the geohydrologic frameworks of the basin (Thorn and others, 1993 ) and the development of a ground-water-flow model by the USGS (Kernodle and others, 1995). In response to concerns from these studies, the USGS began a 6-year Middle Rio Grande initiative (1996-2001) to expand our understanding of basin hydrology (Bartolino and Cole, 2002). As part of that initiative, the present study used ${ }^{14} \mathrm{C}$ activities and the location of hydrochemical zones as observations to estimate parameters for a predevelopment ground-water-flow model of the Middle Rio Grande Basin. Water levels in the basin were simulated using MODFLOW, and travel times to wells and source-area delineation were simulated using MODPATH. The inverse modeling code UCODE was used to help estimate hydraulic conductivities of hydrogeologic units and modern and past recharge to the basin along the basin margins and tributary rivers. Some of the parameter values from this study were incorporated into an updated ground-water model of the basin (McAda and Barroll, 2002).

In the present study a three-dimensional geologic model of the basin (Cole, 2001b) was discretized into a three-dimensional MODFLOW grid of the basin. Major hydrogeologic units in the geologic model include volcanic rocks, and several units that represent the Santa Fe Group sediments, including ancestral gravels from the Rio Grande and some finer grained units that represent the middle and lower Santa Fe Group. The MODFLOW grid represented the hydrogeologic units with nine layers of variable thickness totaling more than 12,000 feet in places, and a uniform horizontal grid resolution of 1 square kilometer. Observations that were used to calibrate a steady-state model and then a transient paleohydrologic model included 200 water levels, $200{ }^{14} \mathrm{C}$ activities, and 9 hydrochemical-target regions. Observed water levels were compared with simulated water levels calculated with MODFLOW, ${ }^{14} \mathrm{C}$ activities were compared with simulated activities based on travel times to individual wells calculated with MODPATH, and the percentage of river water in the hydrochemical-target regions was compared with the percentage of simulated river water. The observed ${ }^{14} \mathrm{C}$ activities, corrected ages, and the extent of hydrochemical zones within the basin are described in detail by Plummer and others (2004).

Hydraulic conductivities estimated for the model were similar to values that had been estimated in the previous models of Kernodle and others (1995) and Tiedeman and others (1998). The estimates for the hydraulic conductivity of the Rio Grande alluvium ranged from 5 feet per day in the north 
to 160 feet per day in the south, with values for the gravels beneath Albuquerque at 1,200 feet per day (but with a linear confidence interval extending well below 100 feet per day). In addition, the hydraulic conductivity of the volcanic rock unit was estimated to be 26 feet per day, and the hydraulic conductivity of a silty layer identified in the geologic model was estimated to be 0.44 feet per day. Estimates of vertical anisotropy for the various units ranged from 0.0003 to 0.004 .

Basin-margin and tributary recharges estimated for the model were lower than values used in previous models. These values overall were estimated to be about 35,000 acre-feet per year of external recharge. The model calculated an additional 20,000 acre-feet per year leaking from the Rio Grande, bringing the total recharge to the basin to 55,000 acre-feet per year. The earlier model of Kernodle and others (1995) had assigned an external recharge of 138,600 acre-feet per year, and Tiedeman and others (1998) estimated an external recharge of 95,500 acre-feet per year. Although the latter value was from a calibrated model, the majority of observations were water-level measurements, with few flux-based observations to constrain flow or recharge rates. McAda and Barroll (2002) used a lower value of external recharge of 67,500 acre-feet per year, based partially on data from Anderholm (2001). The current model has 200 ground-water ages to constrain fluxes from external boundaries, and in so doing suggests some of the earlier inflow estimates from adjacent basins (Frenzel and Lyford, 1982; McAda and Wasiolek, 1988; Frenzel, 1995; Hawley and Grant, 1997) may have been too high. In addition, the rainfall-runoff methods used to estimate recharge in the earlier models do not account for runoff that enters the Rio Grande, or evapotranspiration of runoff once it enters the subsurface. Recharge estimates for the eastern mountain fronts have been made independently using the chloride mass-balance method (Anderholm, 2001). Estimates by the chloride method (11,200 acre-feet per year) were much closer to the estimates of this study $(8,400$ acre-feet per year) than to those of the previous models (greater than 40,000 acre-feet per year).

In the current study, a ground-water trough was simulated west of the Rio Grande with an associated zone of ground water derived from the Rio Grande. The trough and the Rio Grande-derived ground water were clearly observed in the predevelopment water-table map and hydrochemical zones. Rio Grande water was simulated under steady-state conditions in more of the trough than is observed, but this is consistent with the trough being a transient feature since the last glacial maximum and Rio Grande water in the trough dating to about 10,000 or so years. The earlier models with greater recharge did not reproduce these features very effectively.

A transient paleohydrologic model was calibrated to determine if the ${ }^{14} \mathrm{C}$ data as a whole contained information indicating that recharge rates had changed during the past 30,000 years. Paleolimnological evidence from central New Mexico has indicated that the climate in the region was wetter during the last glacial maximum (20,000-25,000 years ago). The transient simulation was for a period of 30,000 years, with an independent value of recharge estimated every 2,500 years. Although there is uncertainty in the results, especially before 20,000 years ago, the transient model suggested that recharge to the basin was substantially higher during the last glacial maximum than at present, and perhaps slightly lower just before the beginning of the Holocene period than at present. 


\section{REFERENCES CITED}

Allen B.D., and Anderson, R.Y., 2000, A continuous, high-resolution record of the late Pleistocene climate variability from the Estancia basin, New Mexico: Geological Society of America Bulletin, v. 112, no. 9, p. 1,444-1,458.

Anderholm, S.K., 1988, Ground-water geochemistry of the Albuquerque-Belen Basin, central New Mexico: U.S. Geological Survey Water-Resources Investigations Report 86-4174, 37 p.

Anderholm, S.K., 2001, Mountain-front recharge along the eastern side of the Middle Rio Grande Basin, central New Mexico: U.S. Geological Survey Water-Resources Investigations Report 00-4010, 36 p.

Anderman, E.R., Hill, M. C., and Poeter, E. P., 1996, The use of advective-transport observations to improve ground-water flow parameter estimation: Ground Water, v. 34, no. 6, p. 1001-1009.

Athy, L.F., 1930, Density, porosity, and compaction of sedimentary rocks: Bulletin of the American Association of Petroleum Geologists, v. 14, p. 1-24.

Bachhuber, F.W., 1992, A pre-late Wisconsin paleolimnologic record from the Estancia Valley, central New Mexico, in Clark, P.U., and Lea, P.D., eds., The last interglacial-glacial transition in North America: Geological Society of America Special Paper 270, p. 289-307.

Bartolino, J.R., and Cole, J.C., 2002, Ground-water resources of the Middle Rio Grande Basin: U.S. Geological Survey Circular $1222,132 \mathrm{p}$.

Bartolino, J.R., and Niswonger, R.G., III, 1999, Numerical simulation of vertical ground-water flux of the Rio Grande from ground-water temperature profiles, central New Mexico: U.S. Geological Survey Water-Resources Investigations Report 99$4212,34 \mathrm{p}$.

Bartolino, J.R., and Sterling, J.M., 1999, Electromagnetic surveys in the Rio Grande flood plain, Middle Rio Grande Basin, New Mexico-Third-year status, in Bartolino, J.R., ed., U.S. Geological Survey Middle Rio Grande Basin Study—Proceedings of the Third Annual Workshop, Albuquerque, New Mexico, February 24-25, 1999: U.S. Geological Survey Open-File Report 99-203, p. 23-24.

Bexfield, L.M., and Anderholm, S. K., 2000, Predevelopment water-level map of the Santa Fe Group aquifer system in the Middle Rio Grande Basin between Cochiti Lake and San Acacia, New Mexico: U.S. Geological Survey Water-Resources Investigations Report 00-4249, 1 p.

Bexfield, L.M., and Anderholm, S. K., 2002, Spatial patterns and temporal variability of water quality from City of Albuquerque drinking-water supply wells and piezometer nests, with implications for the ground-water flow system: U.S. Geological Survey Water-Resources Investigations Report 01-4244, 101 p.

Bjorklund, L.J., and Maxwell, B. W., 1961, Availability of ground water in the Albuquerque area, Bernalillo and Sandoval Counties, New Mexico: New Mexico State Engineer Technical Report 21, 117 p.

Blaney, H.F., Ewing, P. A., Israelsen, O. W., Rohwer, C., and Scobey, F. C., 1938, Water utilization, in (U.S.) National Resources Committee, Regional Planning part VI-The Rio Grande joint investigations in the upper Rio Grande Basin in Colorado, New Mexico, and Texas, 1936-37: U.S. Government Printing Office v. 1, p. 293-427.

Bryan, K., 1938, Geology and ground-water conditions of the Rio Grande depression in Colorado and New Mexico, in (U.S.) National Resources Committee, Regional Planning part VI-The Rio Grande joint investigations in the upper Rio Grande Basin in Colorado, New Mexico, and Texas, 1936-37: U.S. Government Printing Office v. 1, p. 197-225.

Bureau of Reclamation, 1973, Progress report-Phreatophyte investigations-Bernardo evapotranspirometers: Middle Rio Grande Project Office, $50 \mathrm{p}$.

Cole, J.C., ed., 2001a, U.S. Geological Survey Middle Rio Grande Basin Study-Proceedings of the Fourth Annual Workshop, Albuquerque, New Mexico, February 2000: U.S. Geological Survey Open-File Report 00-488, 51 p.

Cole, J.C., 2001b, 3-D geologic modeling of regional hydrostratigraphic units in the Albuquerque segment of the Rio Grande rift, in Cole, J. C., ed., U.S. Geological Survey: Middle Rio Grande Basin Study-Proceedings of the Fourth Annual Workshop, Albuquerque, New Mexico, February 15-16, 2000, U.S. Geological Survey Open-File Report 00-488, p. 26-28. 
Connell, S.D., Allen, B.D., and Hawley, J.W, 1998, Subsurface stratigraphy of the Santa Fe Group from borehole geophysical logs, Albuquerque area, New Mexico: New Mexico Geology, v. 20, no. 1, p. 2-7.

Constantz, J., 1998, Measurements of tributary, inter-arroyo, and mountain-front recharge on the Santa Fe River, Bear Canyon, and Abo Arroyo, New Mexico, in Slate, J.L., ed., 1998, U.S. Geological Survey Middle Rio Grande Basin Study-Proceedings of the Second Annual Workshop, Albuquerque, New Mexico, February 10-11, 1998: U.S. Geological Survey Open-File Report 98-337, p. 55-56.

Cooley, R.L., and Naff, R.L., 1990, Regression modeling of ground-water flow: U.S. Geological Survey Techniques of Water Resources Investigations, book 3, chap. B4, 232 p.

Cummins, B., 1997, Middle Rio Grande Water Assessment—Drilling, logging, monitoring, well installation, hydraulic conductivity tests, and infiltration gallery feasibility evaluation technical memoranda: U.S. Bureau of Reclamation, Albuquerque Area Office, Supporting document number 8, variously paged.

Deszcz-Pan, M., Rodriguez, B.D., Sawyer, D.A., Stone, B.D., Godbout, M., Doucette, J., Grauch, V. J. S., and Labson, V. F. , 1999, Application of electromagnetic surveys to geologic and hydrologic problems in the Middle Rio Grande Basin area, in Bartolino, J.R., ed., U.S. Geological Survey Middle Rio Grande Basin Study-Proceedings of the Third Annual Workshop, Albuquerque, New Mexico, February 24-25, 1999: U.S. Geological Survey Open-File Report 99-203, p. 35-36.

Driscoll, F. G., 1986, Groundwater and wells: Johnson Filtration Systems Inc., St. Paul, Minn., 1,089 p.

Freeze, R.A., and Cherry, J.A., 1979, Groundwater: Englewood Cliffs, Prentice-Hall, N.J., 604 p.

Frenzel, P.F., 1995, Geohydrology and simulation of ground-water flow near Los Alamos, north-central New Mexico: U.S. Geological Survey Water-Resources Investigations Report 95-4091, 92 p.

Frenzel, P.F., and Lyford, F.P., 1982, Estimates of vertical hydraulic conductivity and regional ground-water flow rates in rocks of Jurassic and Cretaceous age, San Juan Basin, New Mexico and Colorado: U.S. Geological Survey Water-Resources Investigations Report 82-4015, $59 \mathrm{p}$.

Giles, M.R., 1997, Diagenesis: A quantitative perspective-Implications for basin modeling and rock property prediction: Dorcrecht, Kluwer Academic Publishers, 526 p.

Gould, J., 1997, Middle Rio Grande Water Assessment—Middle Rio Grande channel permeameter investigations: U.S. Bureau of Reclamation, Albuquerque Area Office, supporting document number 11, variously paged.

Grauch, V.J.S., Sawyer, D.A., Keller, G.R., and Gillespie, C.L., 2001, Contributions of gravity and aeromagnetic studies to improving the understanding of the subsurface hydrogeology, Middle Rio Grande Basin, New Mexico. In Cole, J.C., ed., U.S. Geological Survey Middle Rio Grande Basin Study_Proceedings of the Fourth Annual Workshop, Albuquerque, New Mexico, February 15-16, 2000: U.S. Geological Survey Open-File Report 00-488, p. 3-4.

Haneberg, W.C., 1995, Depth-porosity relationships and virgin specific storage estimates for the upper Santa Fe Group aquifer system, central Albuquerque Basin, New Mexico: New Mexico Geology, v. 17, no. 4, p. 62-71.

Hawley, J.W., and Grant, P.R., Jr., 1997, Boundaries of the Albuquerque geohydrologic basin, north-central New Mexico [abs.]: New Mexico Geology, v. 19, no. 2, p. 60.

Hawley, J.W., and Haase, C.S., 1992, Hydrogeologic framework of the northern Albuquerque Basin: Socorro, New Mexico Bureau of Mines and Mineral Resources, Open-File Report 387, variously paginated.

Hawley, J.W., Haase, C.S., and Lozinsky, R.P., 1995, An underground view of the Albuquerque Basin, in Ortega-Klett, C.P., ed., The water future of Albuquerque and Middle Rio Grande Basin: Proceedings of the 39th Annual New Mexico Water Conference, November 3-4, 1994, New Mexico Water Resources Research Institute WRRI Report No. 290, p. 37-55.

Hearne, G.A., and Dewey, J. D., 1988, Hydrologic analysis of the Rio Grande Basin north of Embudo, New Mexico, Colorado and New Mexico: U.S. Geological Survey Water-Resources Investigations Report 86-4113, 244 p.

Hill, M.C., 1990, Preconditioned conjugate-gradient 2 (PCG2), a computer program for solving ground-water flow equations:

U.S. Geological Survey Water-Resources Investigations Report 90-4048, 43 p. 
Hill, M.C., 1992, A computer program (MODFLOWP) for estimating parameters of a transient, three-dimensional, groundwater flow model using nonlinear regression: U.S. Geological Survey Open-File Report 91-484, 358 p.

Hill, M.C., 1998, Methods and guidelines for effective model calibration: U.S. Geological Survey Water-Resources Investigations Report 98-4005, 90 p.

Hudson, M.R., Minor, S. A., Grauch, V.J.S., and Personius, S.F., 1999, Preliminary characterization of faults in the Middle Rio Grande Basin, in Bartolino, J. R., ed., 1999, U.S. Geological Survey Middle Rio Grande Basin Study-Proceedings of the Third Annual Workshop, Albuquerque, New Mexico, February 24-25, 1999: U.S. Geological Survey Open-File Report 99203, p. 40-41.

Kalin, R.M., 2000, Radiocarbon dating of groundwater systems, in Cook, P. G., and Herczeg, A. L., eds., Environmental Tracers in Subsurface Hydrology: Boston, Kluwer Academic Publishers, p. 111-144.

Kelley, V.C., 1977, Geology of the Albuquerque Basin, New Mexico: Socorro, New Mexico Bureau of Mines and Mineral Resources Memoir 33, $60 \mathrm{p}$.

Kelley, V.C., and Kudo, A.M., 1978, Volcanoes and related basalts of Albuquerque Basin, New Mexico: Socorro, New Mexico Bureau of Mines and Mineral Resources, Circular 156, 29 p.

Kernodle, J.M., 1998, Simulation of ground-water flow in the Albuquerque Basin, Central New Mexico, 1901-1995, with projections to 2020: U.S. Geological Survey Water-Resources Investigations Report 96-209, 54 p.

Kernodle, J.M., McAda, D.P., and Thorn, C.R., 1995, Simulation of ground-water flow in the Albuquerque Basin, Central New Mexico, 1901-1994, with projections to 2020: U.S. Geological Survey Water-Resources Investigations Report 94-4251, 114 p.

Kernodle, J. M., Miller, R. S., and Scott, W. B., 1987, Three-dimensional model simulation of transient ground-water flow in the Albuquerque-Belen Basin, New Mexico: U.S. Geological Survey Water-Resources Investigations Report 86-4194, 86 p.

Kernodle, J. M., and Scott, W. B., 1986, Three-dimensional model simulation of steady-state ground-water flow in the Albuquerque-Belen Basin, New Mexico: U.S. Geological Survey Water-Resources Investigations Report 84-4353, 58 p.

Lee, W. T., 1907, Water resources of the Rio Grande Valley in New Mexico and their development: U.S. Geological Survey Water-Supply Paper 188, 59 p.

Logan, L. M., 1990, Geochemistry of the Albuquerque municipal area, Albuquerque, New Mexico: Socorro, New Mexico Institute of Mining and Technology, Independent study, $234 \mathrm{p}$.

Love, D. W., Reynolds, C. B., Hallett, B., Lozinsky, R. P., and Niemyjski, T., 1994, Sedimentation, deformation, and erosion related to Los Lunas volcanoes, central New Mexico (abs.): New Mexico Geology, v. 16, no. 3, p. 57.

Lozinsky, R.P., 1988, Stratigraphy, sedimentology, and sand petrology of the Santa Fe Group and pre-Santa Fe Tertiary deposits in the Albuquerque basin, central New Mexico: Socorro, New Mexico Tech, Ph.D. dissertation, 298 p.

Lozinsky, R.P., 1994, Cenozoic stratigraphy, sandstone petrology, and depositional history of the Albuquerque basin, central New Mexico, in Keller, G.R., and Cather, S.M., eds., Basins of the Rio Grande rift: Geological Society of America, Special Paper 291, p. 73-82.

Machette, M.N., Personius, S.F., Kelson, K.I., Haller, K.M., and Dart, R.L., 1998, Map and data for Quaternary faults in New Mexico: U.S. Geological Survey Open-File Report 98-521, 443 p.

McAda, D. P., 1996, Plan of study to quantify the hydrologic relations between the Rio Grande and the Santa Fe Group aquifer system near Albuquerque, central New Mexico: U.S. Geological Survey Water-Resources Investigations Report 96-4006, 58 p.

McAda, D. P., Barroll, P., and Sanford, W. E., 2001, Revision of the ground-water flow model of the Middle Rio Grande Basin, New Mexico, in Cole, J. C., ed., U.S. Geological Survey Middle Rio Grande Basin study—Proceedings of the Fourth Annual Workshop, Albuquerque, New Mexico, February 15-16, 2000: U.S. Geological Survey Open-File Report 00-488, p. 29-30.

McAda, D. P., and Barroll, P., 2002, Simulation of ground-water flow in the Middle Rio Grande Basin between Cochiti and San Acacia, New Mexico: U.S. Geological Survey Water-Resources Investigations Report 02-4200, 81 p. 
McAda, D.P., and Wasiolek, M., 1988, Simulation of the regional hydrology of the Tesuque aquifer system near Santa Fe, New Mexico: U.S. Geological Survey Water-Resources Investigations Report 87-4056, 71 p.

McDonald, M. G., and Harbaugh, A. W., 1988, A modular three-dimensional finite-difference ground-water flow model: U.S. Geological Survey Techniques of Water-Resources Investigations, book 6, chap. A1, variously paged.

Medina, A., and Carrera, J., 1996, Coupled estimation of flow and solute transport parameters: Water Resources Research, v. 32 , p. 3,063-3,076.

Meeks, T.O., 1949, The occurrence of ground water in the Tijeras Soil Conservation District, Bernalillo County, New Mexico: U.S. Department of Agriculture Regional Bulletin 109, Geological Series I. Soil Conservation Service Region 6, variously paged.

Minor, S.A., and Shock, N.A., 1998, Results from the Cochiti and Santo Domingo Pueblos, in Slate, J.L., ed., 1998, U.S. Geological Survey Middle Rio Grande Basin Study_Proceedings of the Second Annual Workshop, Albuquerque, New Mexico, February 10-11, 1998: U.S. Geological Survey Open-File Report 98-337, p. 22-23.

Nimmo, J.R., 1997, Recharging fluxes through layered alluvium-Centrifuge hydraulic property measurements interpreted by Darcian flow simulation, in Bartolino, J.R., ed., U.S. Geological Survey Middle Rio Grande Basin Study_Proceedings of the First Annual Workshop, Denver, Colorado, November 12-14, 1996: U.S. Geological Survey Open-File Report 97-116, p. 45.

Plummer, L.N., Bexfield, L.M., Anderholm, S.K., Sanford, W.E., and Busenberg, E., 2004, Geochemical characterization of ground-water flow in the Santa Fe Group aquifer system, Middle Rio Grande Basin, New Mexico: U.S. Geological Survey Water-Resources Investigations Report 03-4131, 395 p.

Poeter, E.P., and Hill, M.C., 1997, Inverse models-A necessary next step in groundwater modeling: Ground Water, v. 35, no. 2 , p. 250-260.

Poeter, E.P., and Hill, M.C., 1998, Documentation of UCODE, a computer code for universal inverse modeling: U.S. Geological Survey Water-Resources Investigations Report 98-4080, 116 p.

Pollock, D.W., 1994, User's guide for MODPATH/MODPATH-PLOT, version 3-A particle tracking post-processing package for MODFLOW, the U.S. Geological Survey finite-difference ground-water flow model: U.S. Geological Survey Open-File Report 94-464, variously paged.

Raymo, M.E., and Ruddiman, W.F., 1992, Tectonic forcing of late Cenozoic climate: Nature, v. 359, no. 6391, p. 117-122.

Rodriguez, B.D., Deszcz-Pan, M., Sawyer, D., and Stone, B.D., 2001, Subsurface constraints on the hydrogeologic model of the Middle Rio Grande Basin, New Mexico, using airborne time-domain electromagnetic data, in Cole, J.C., ed., U.S. Geological Survey Middle Rio Grande Basin Study—Proceedings of the fourth Annual Workshop, Albuquerque, New Mexico, February 15-16, 2000: U.S. Geological Survey Open-File Report 00-488, p. 20-23.

Sanford, W.E., Plummer, N.L., and Bexfield, L.M., 1998, Using environmental tracer data to improve the U.S. Geological Survey MODFLOW model of the Middle Rio Grande Basin, in Slate, J. L., ed., U.S. Geological Survey Middle Rio Grande Basin Study_-Proceedings of the Second Annual Workshop, Albuquerque, New Mexico, February 10-11, 1998: U.S. Geological Survey Open-File Report 98-337, p. 13-14.

Sanford, W. E., Plummer, N.L., McAda, D. P., Bexfield, L. M., and Anderholm, S. K., 2001, Estimation of hydrologic parameters for the ground-water model of the Middle Rio Grande Basin using carbon-14 and water-level data, in Cole, J. C., ed., U.S. Geological Survey Middle Rio Grande Basin Study-Proceedings of the Fourth Annual Workshop, Albuquerque, New Mexico, February 15-16, 2000: U.S. Geological Survey Open-File Report 00-488, p. 4-6.

Stewart, A.E., and Constantz, J., 2000, Determination of streamflow patterns to estimate stream loss along Abo Arroyo, New Mexico, in Cole, J. C., ed., U.S. Geological Survey Middle Rio Grande Basin Study-Proceedings of the Fourth Annual Workshop, Albuquerque, New Mexico, February 15-16, 2000: U.S. Geological Survey Open-File Report 00-488, p. 35-37.

Stone, B.D., 2001, Sedimentary, stratigraphic, and hydrologic consequences of syn-depositional faulting in the Rio Grande rift, in Cole, J.C., ed., U.S. Geological Survey Middle Rio Grande Basin Study-Proceedings of the Fourth Annual Workshop, Albuquerque, New Mexico, February 15-16, 2000: U.S. Geological Survey Open-File Report 00-488, p. 14-18. 
Stone, B.D., and Allen, B.D., 1998, The 98th Street core-Key to analysis of Santa Fe Group stratigraphy and hydrogeology in the central Middle Rio Grande Basin, in Slate, J. L., ed., U.S. Geological Survey Middle Rio Grande Basin Study-Proceedings of the Second Annual Workshop, Albuquerque, New Mexico, February 10-11, 1998: U.S. Geological Survey Open-File Report 98-337, p. 41-46.

Stone, B.D., Cole, J.C., and Sawyer, D.A., 2001, Regional stratigraphic framework of the three-dimensional geologic model of the Rio Grande rift, in Cole, J.C., ed., U.S. Geological Survey Middle Rio Grande Basin Study-Proceedings of the Fourth Annual Workshop, Albuquerque, New Mexico, February 15-16, 2000: U.S. Geological Survey Open-File Report 00-488, p. $11-13$.

Stonestrom, D.A., and Atkins, K.C., 1998, Environmental tracers of recharge at Abo Arroyo, Bear Canyon, and the Santa Fe River, Middle Rio Grande Basin, New Mexico, in Slate, J.L., ed., U.S. Geological Survey Middle Rio Grande Basin StudyProceedings of the Second Annual Workshop, Albuquerque, New Mexico, February 10-11, 1998: U.S. Geological Survey Open-File Report 98-337, p. 57-59.

Stuiver, M., Reimer, P.J., Bard, E., Beck, J.W., Burr, G., Hughen, K.A., Kromer, B., McCormac, F.G., van der Plicht, J., and Spurk, M., 1998, INTCAL98 Radiocarbon age calibration, 24,000-0 cal BP: Radiocarbon, v. 40, no. 3, p. 1041.

Thompson, C.L., Stewart, A.E., and Constantz, J., 1999, Comparison of methods to determine infiltration and percolation rates along a reach of the Santa Fe River near La Bajada, New Mexico, in Bartolino, J.R., ed., 1999, U.S. Geological Survey Middle Rio Grande Basin Study-Proceedings of the Third Annual Workshop, Albuquerque, New Mexico, February 24-25, 1999: U.S. Geological Survey Open-File Report 99-203, p. 75-76.

Thorn, C.R., McAda, D.P., and Kernodle, J.M, 1993, Geohydrologic framework and hydrologic conditions in the Albuquerque Basin, central New Mexico: U.S. Geological Survey Water-Resources Investigations Report 93-4149, 106 p.

Tiedeman, C. R., Kernodle, J. M., and McAda, D. P., 1998, Application of nonlinear-regression methods to a ground-water flow model of the Albuquerque Basin, New Mexico: U.S. Geological Survey Water-Resources Investigations Report 98-4172, 90 p.

Titus, F. B., 1963, Geology and ground-water conditions in eastern Valencia County, New Mexico: Socorro, New Mexico Bureau of Mines and Mineral Resources Ground-Water Report 7, 113 p.

Waltemeyer, S. D., 1994, Methods for estimating streamflow at mountain fronts in southern New Mexico: U.S. Geological Survey Water-Resources Investigations Report 93-4213, 17 p.

Willis, W. S., 1993, Middle Rio Grande ground-water studies: Bureau of Reclamation, Middle Rio Grande Water Assessment, Technical Memorandum, June 30, 1993, variously paged.

Zhu, C., 2000, Estimate of recharge from radiocarbon dating of groundwater and numerical flow and transport modeling: Water Resources Research, v. 36, no. 7, p. 2,607-2,620.

Zhu, C., Winterle, J. R., and Love, E. I., 2003, Late Pleistocene and Holocene groundwater recharge from the chloride mass balance method and chlorine-36 data: Water Resources Research, v. 39., no. 7, 15 p., DOI 10.1029/2003WR001987. 


\section{APPENDIX A. Information and Observations for Individual Wells}

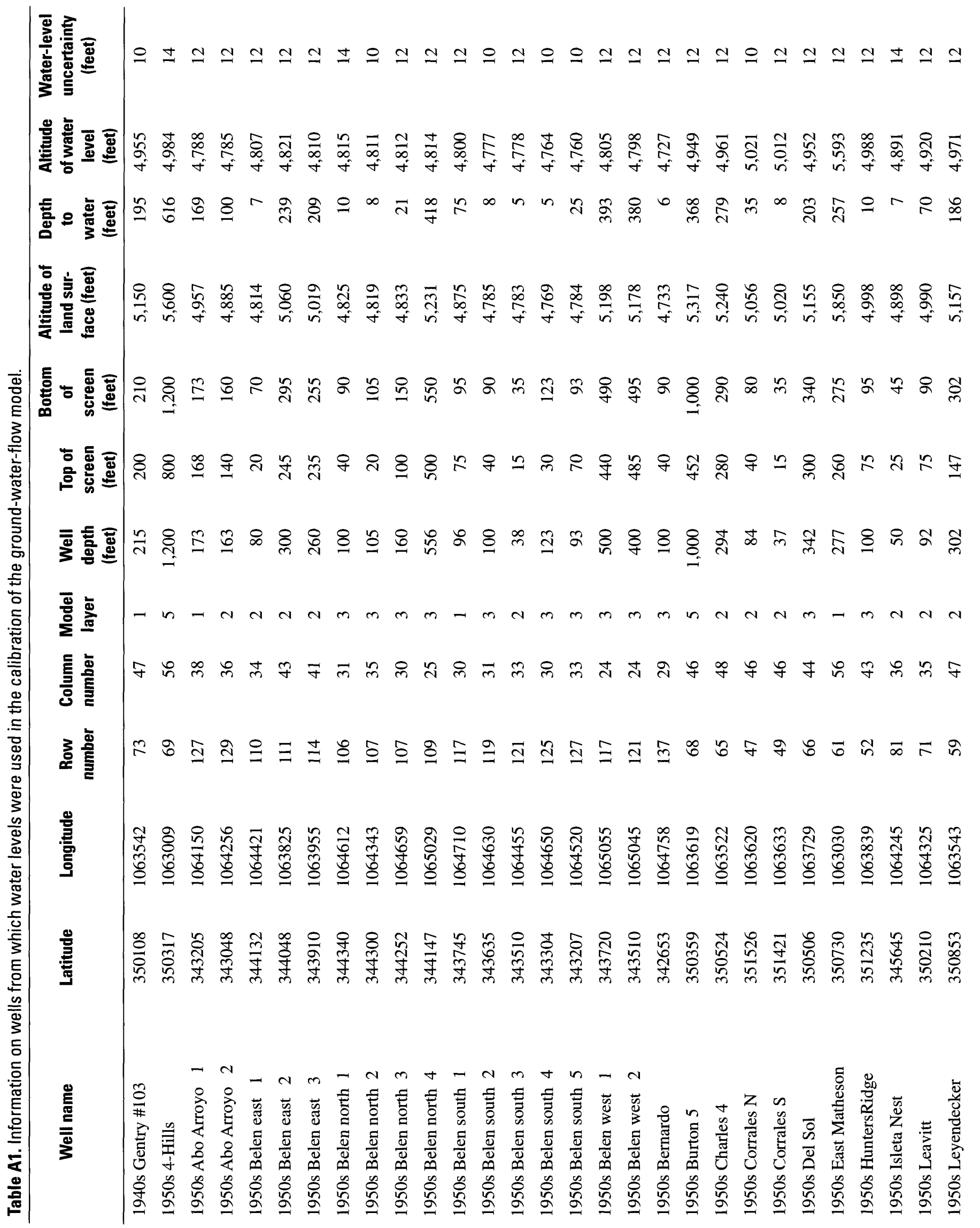




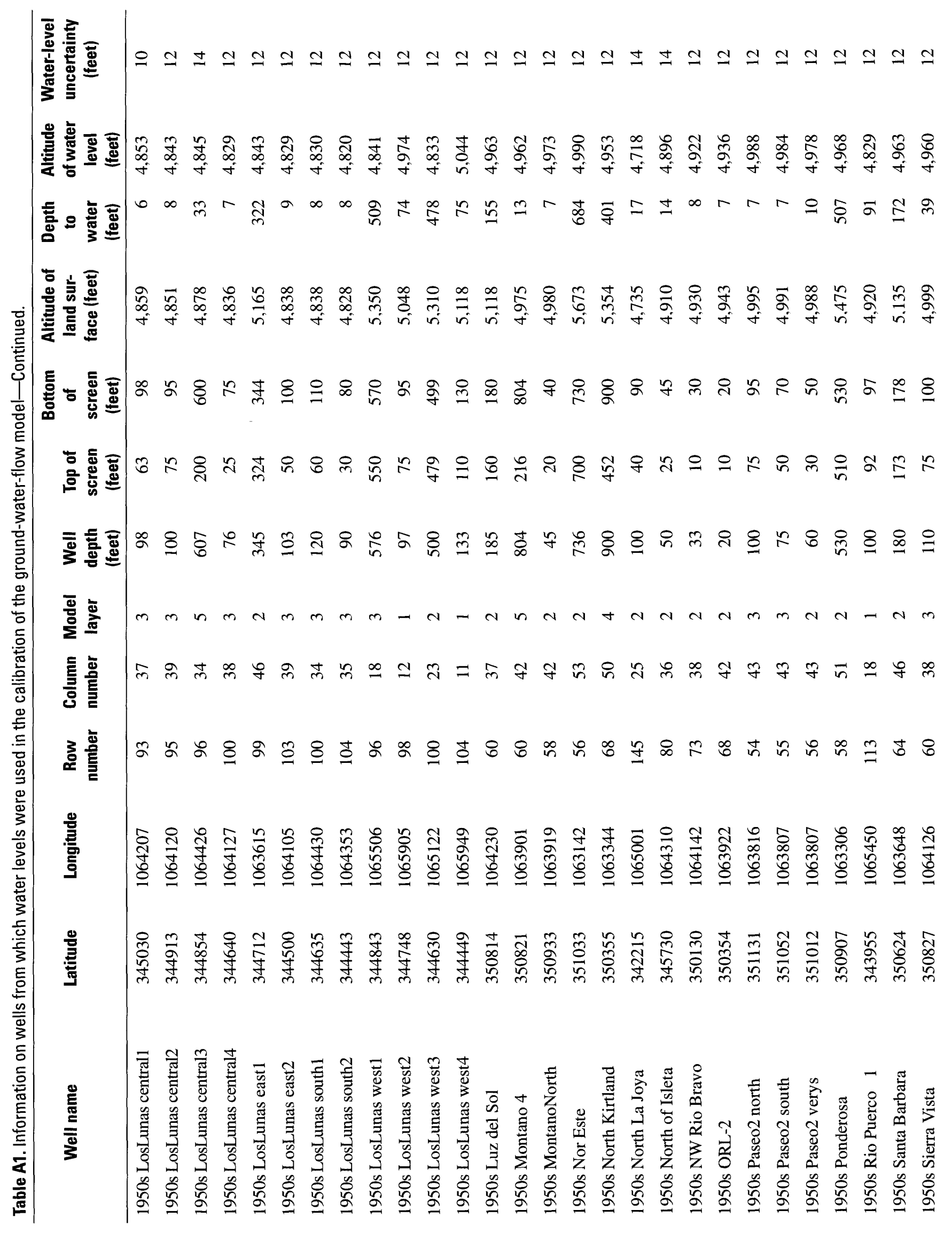




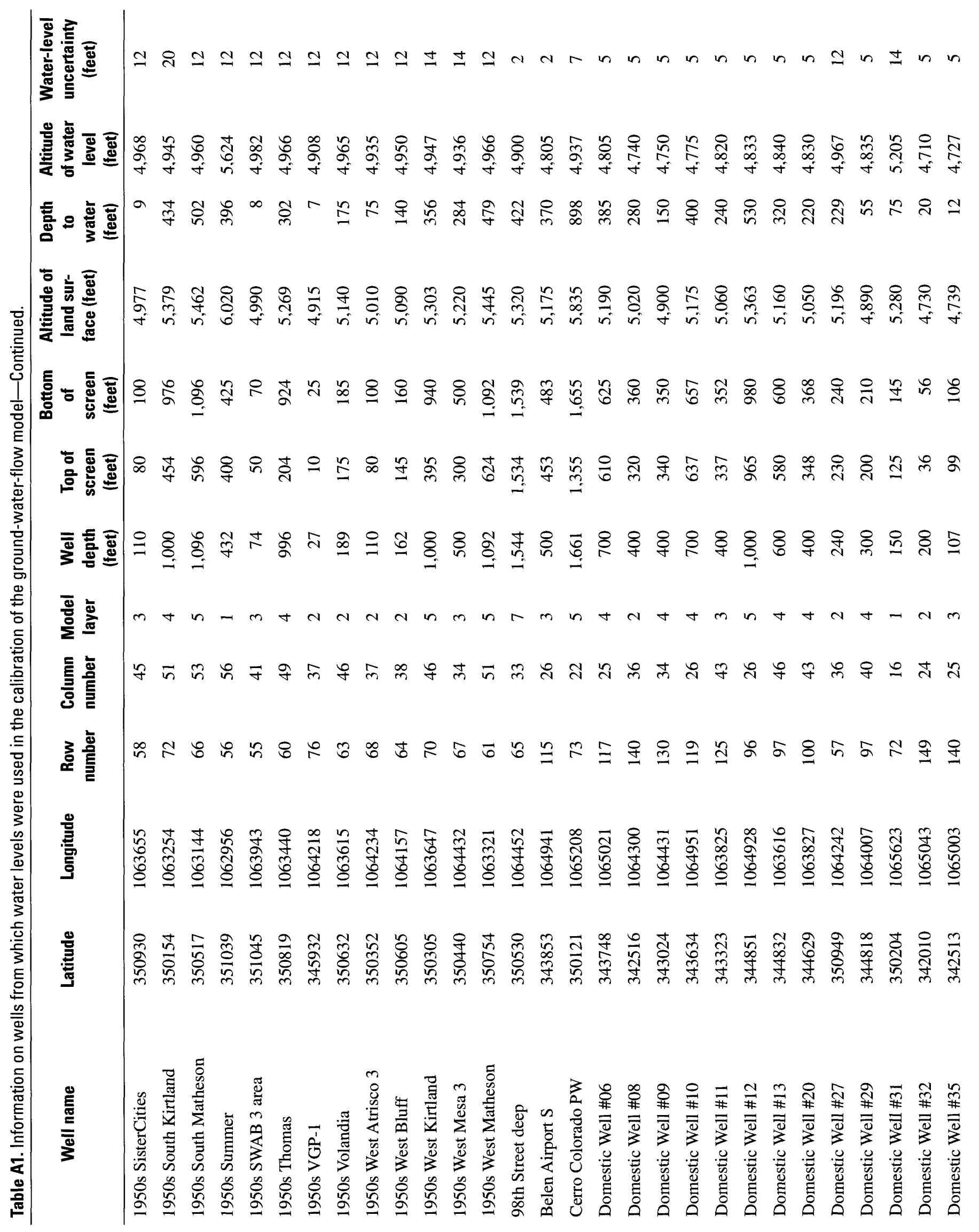




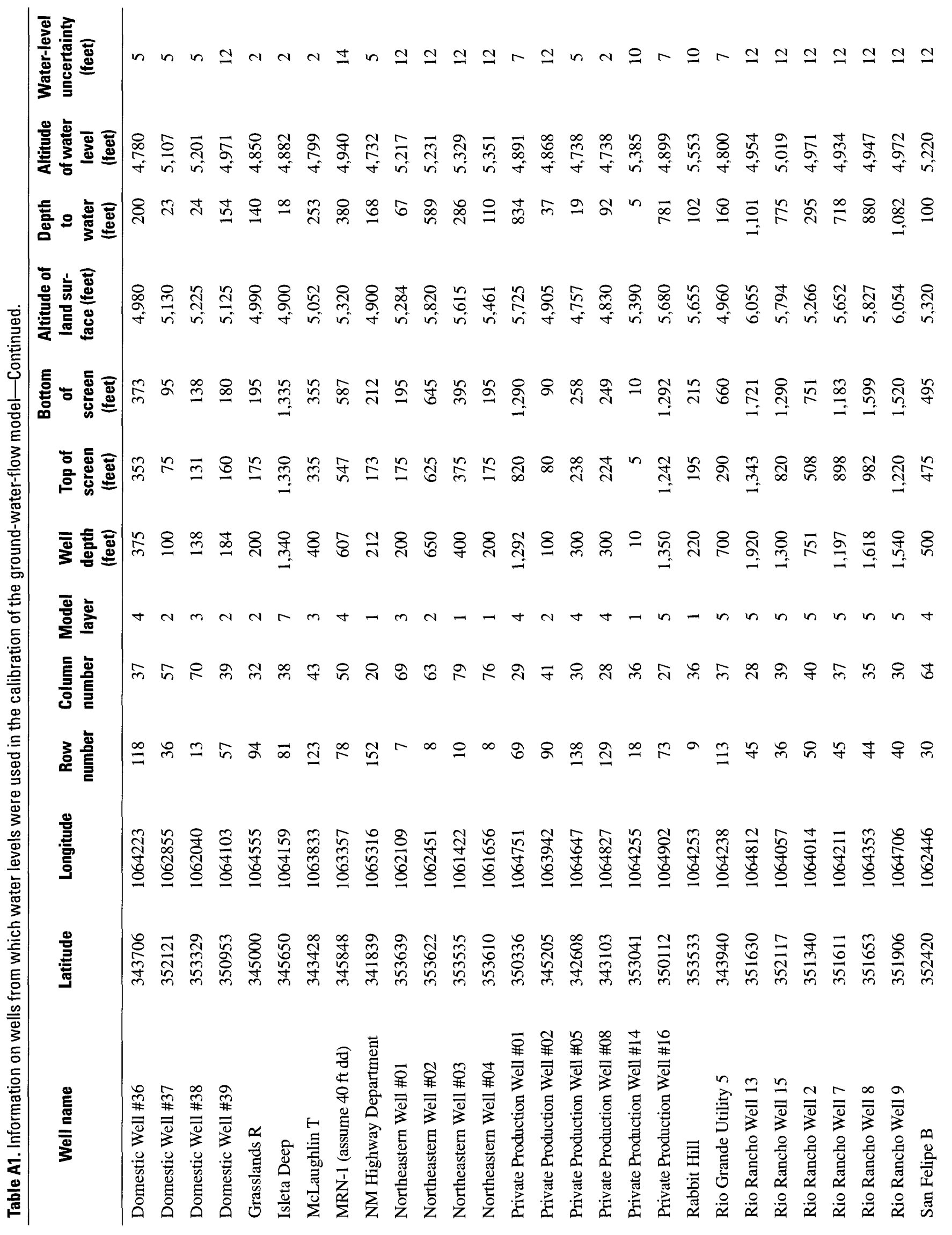




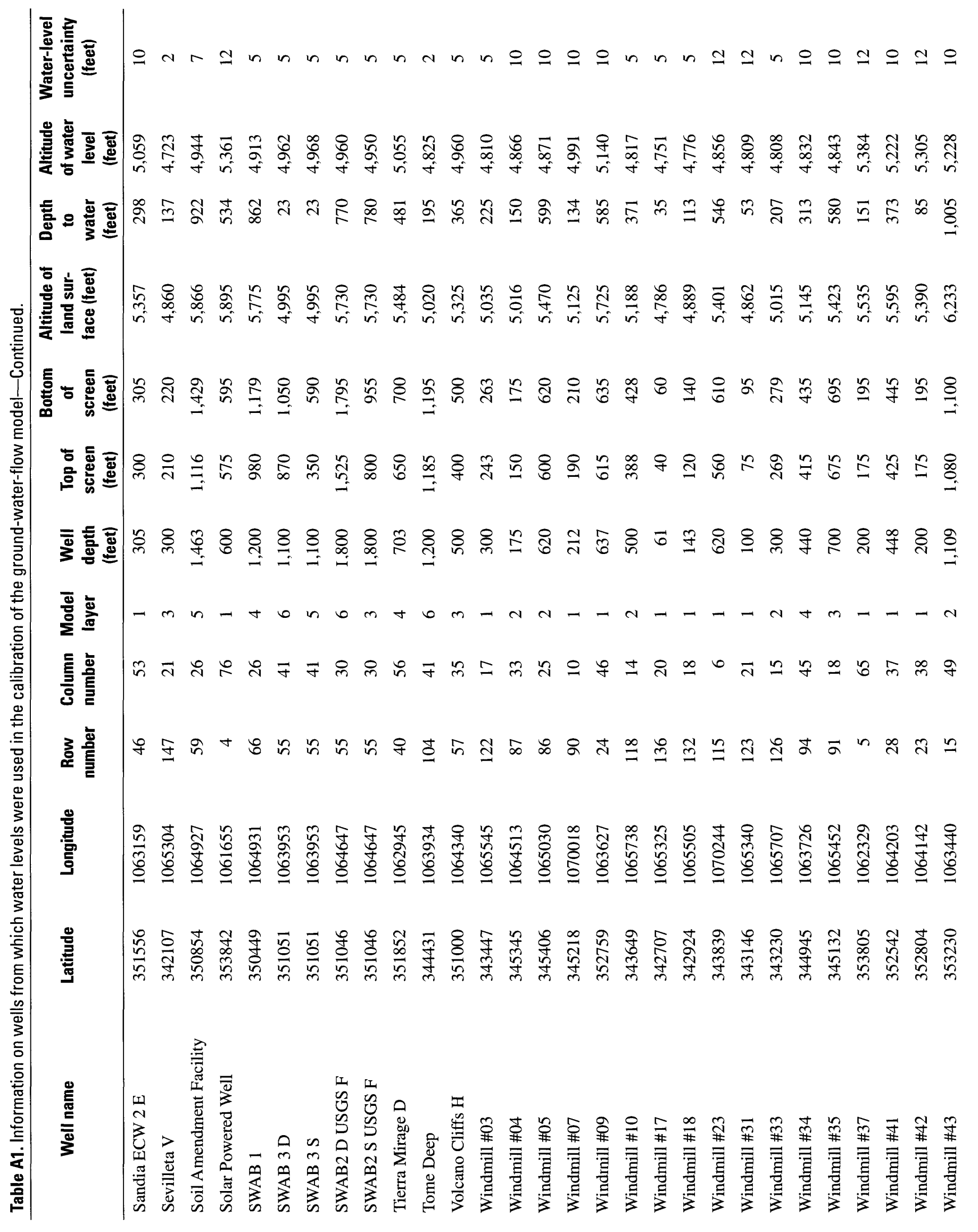




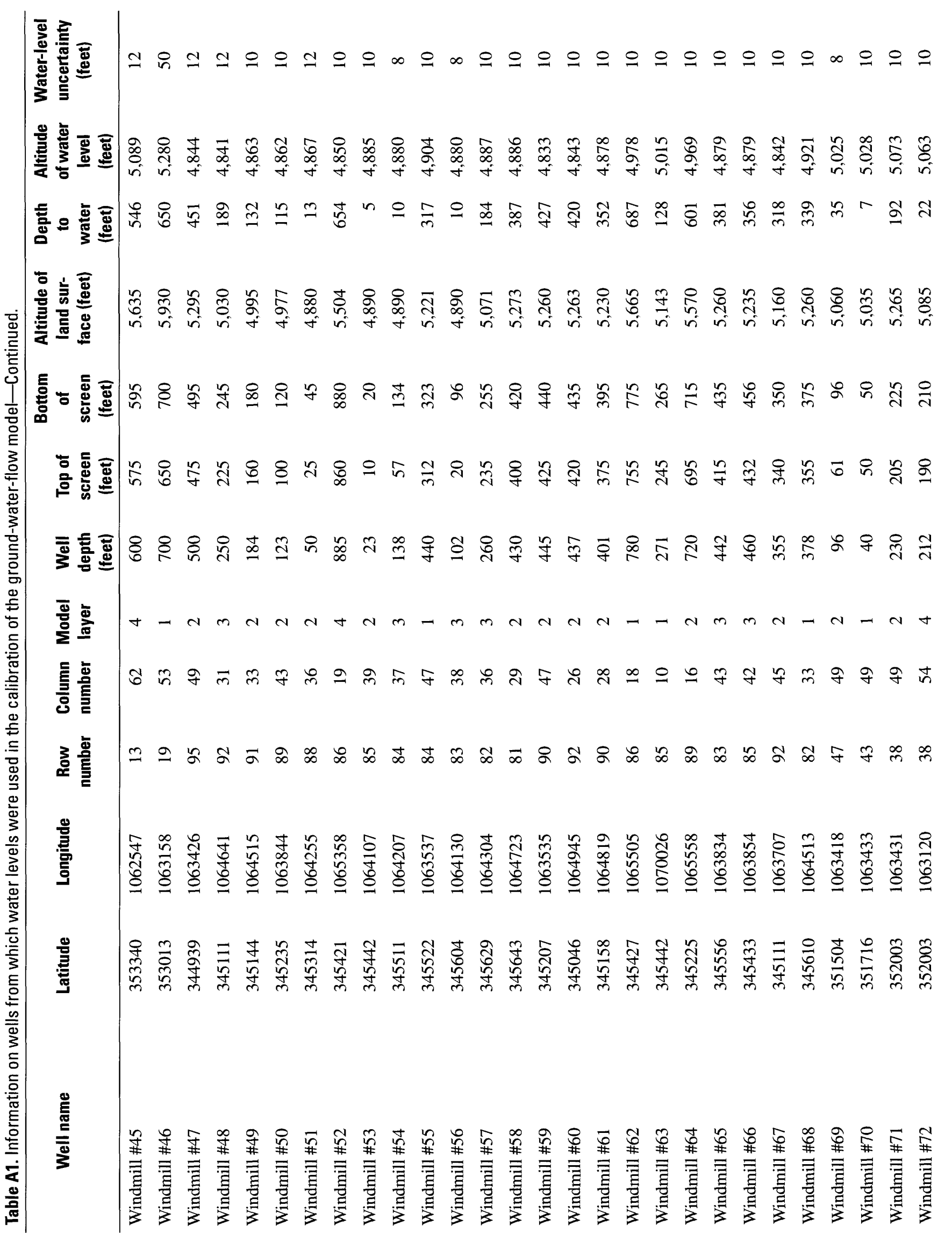




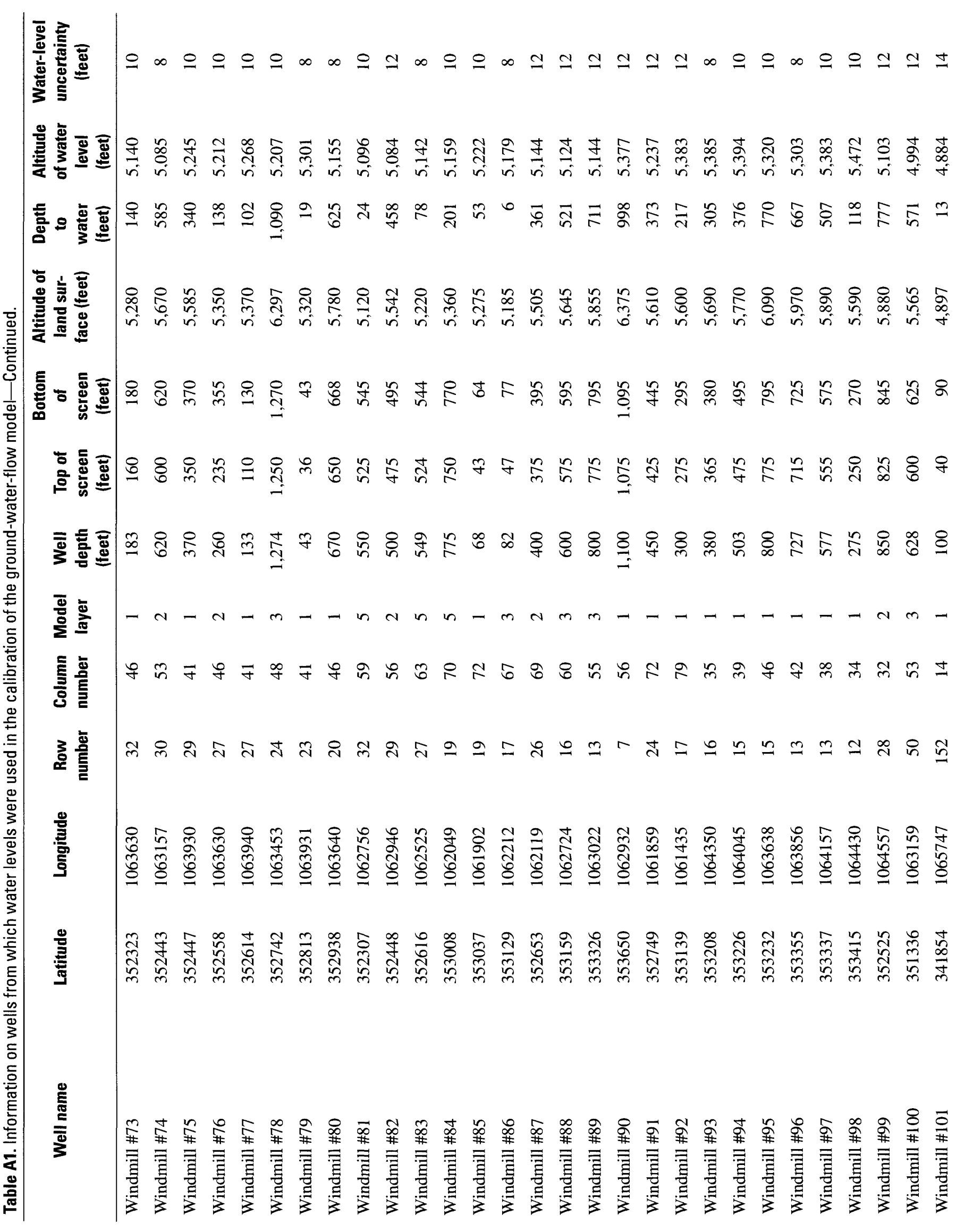




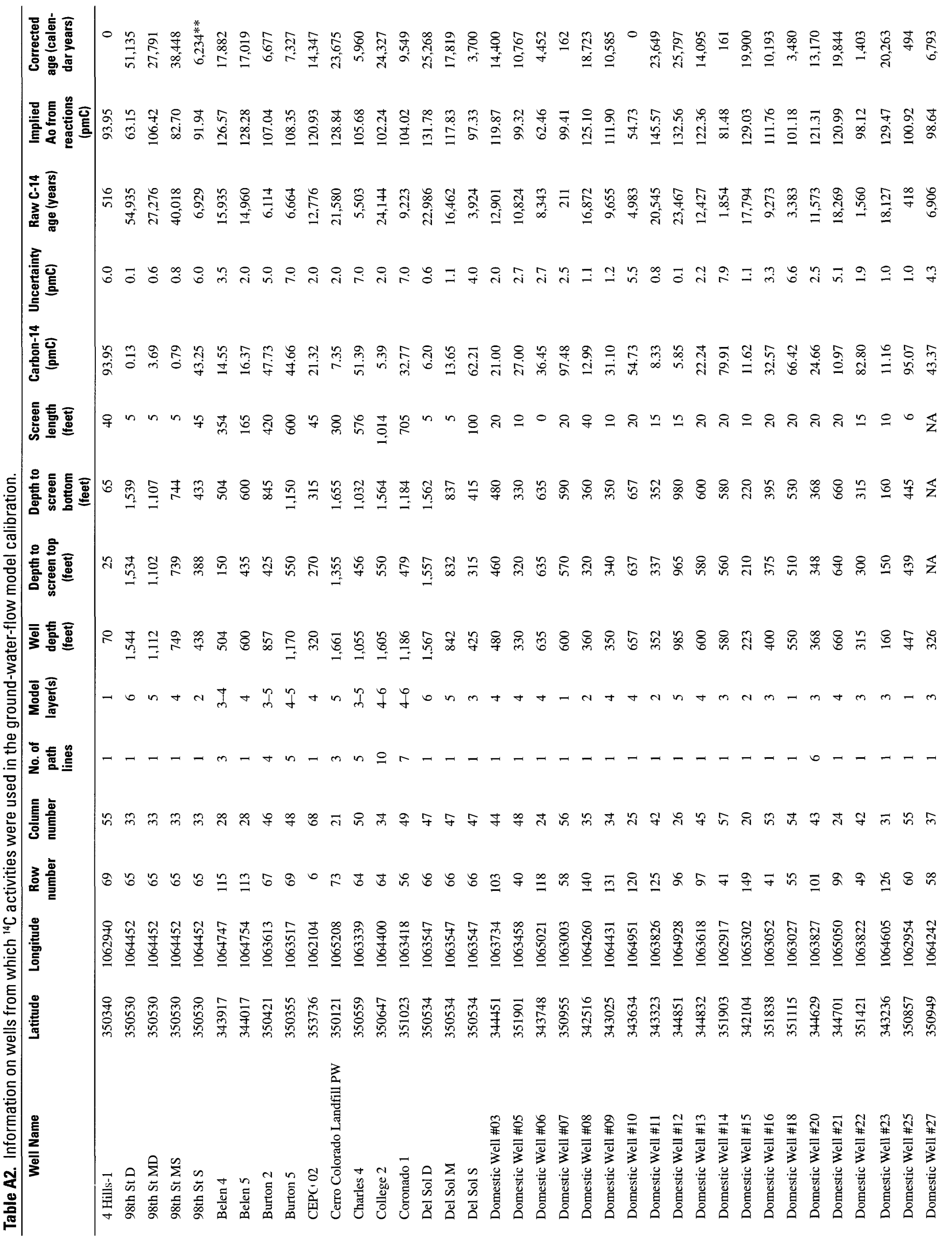




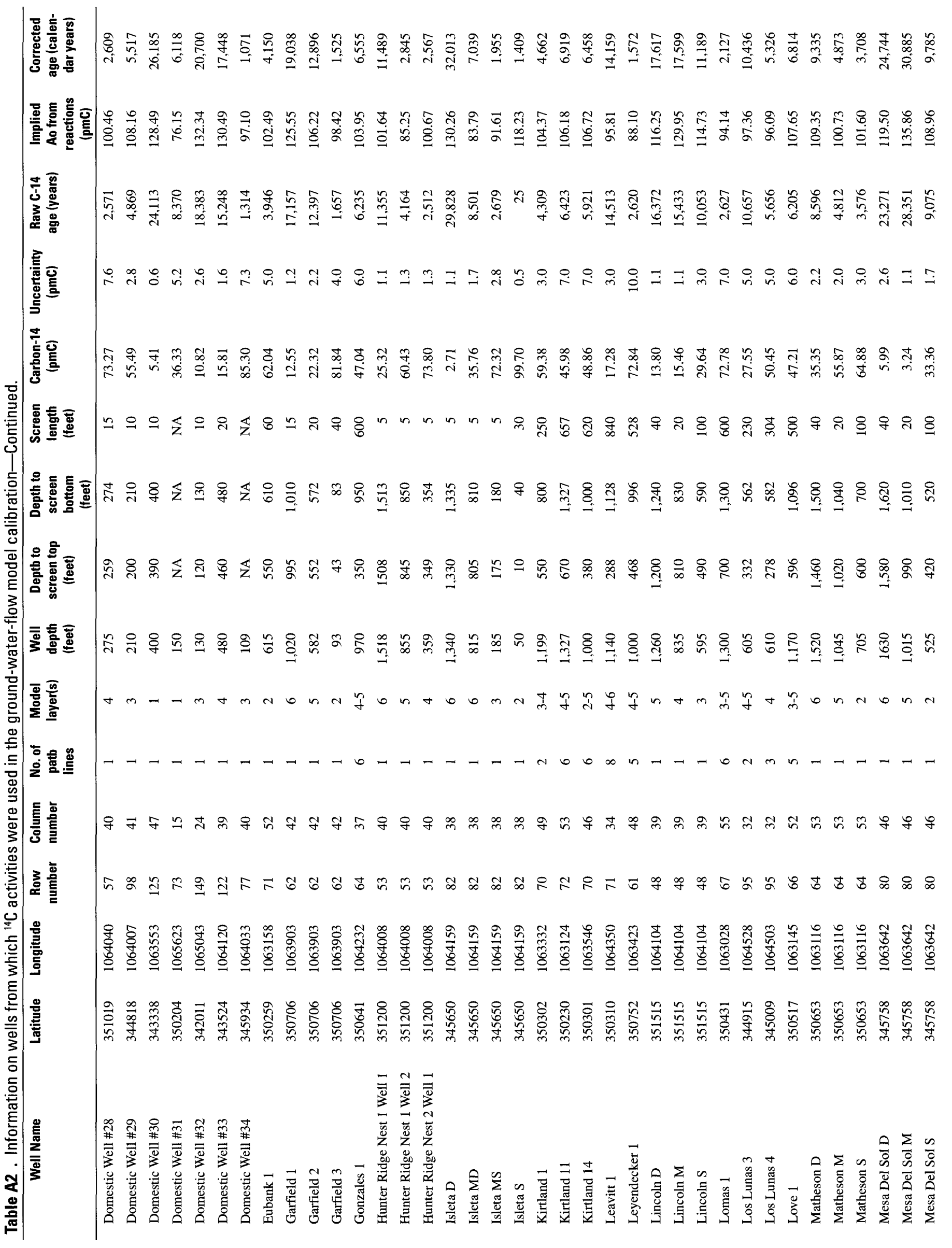




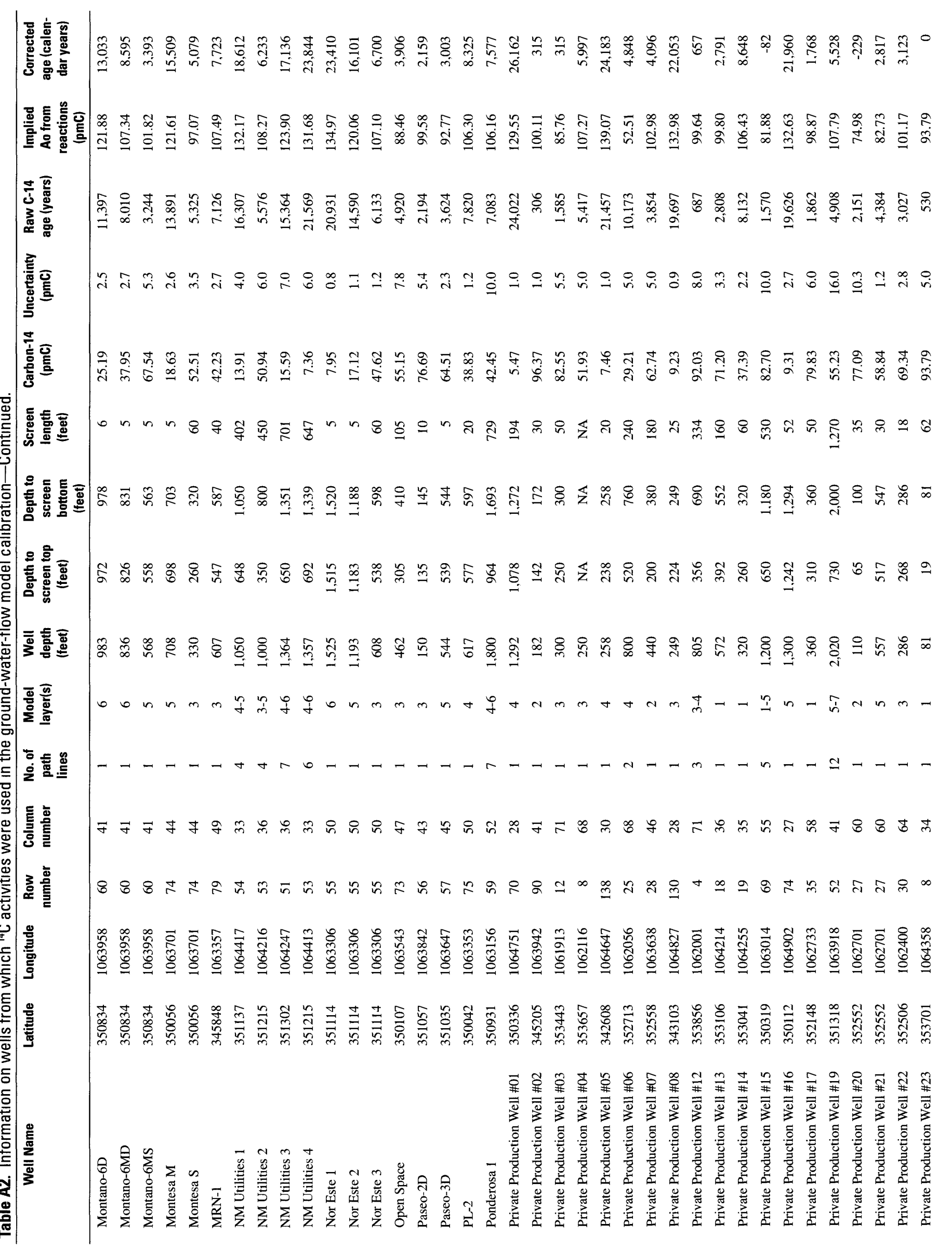




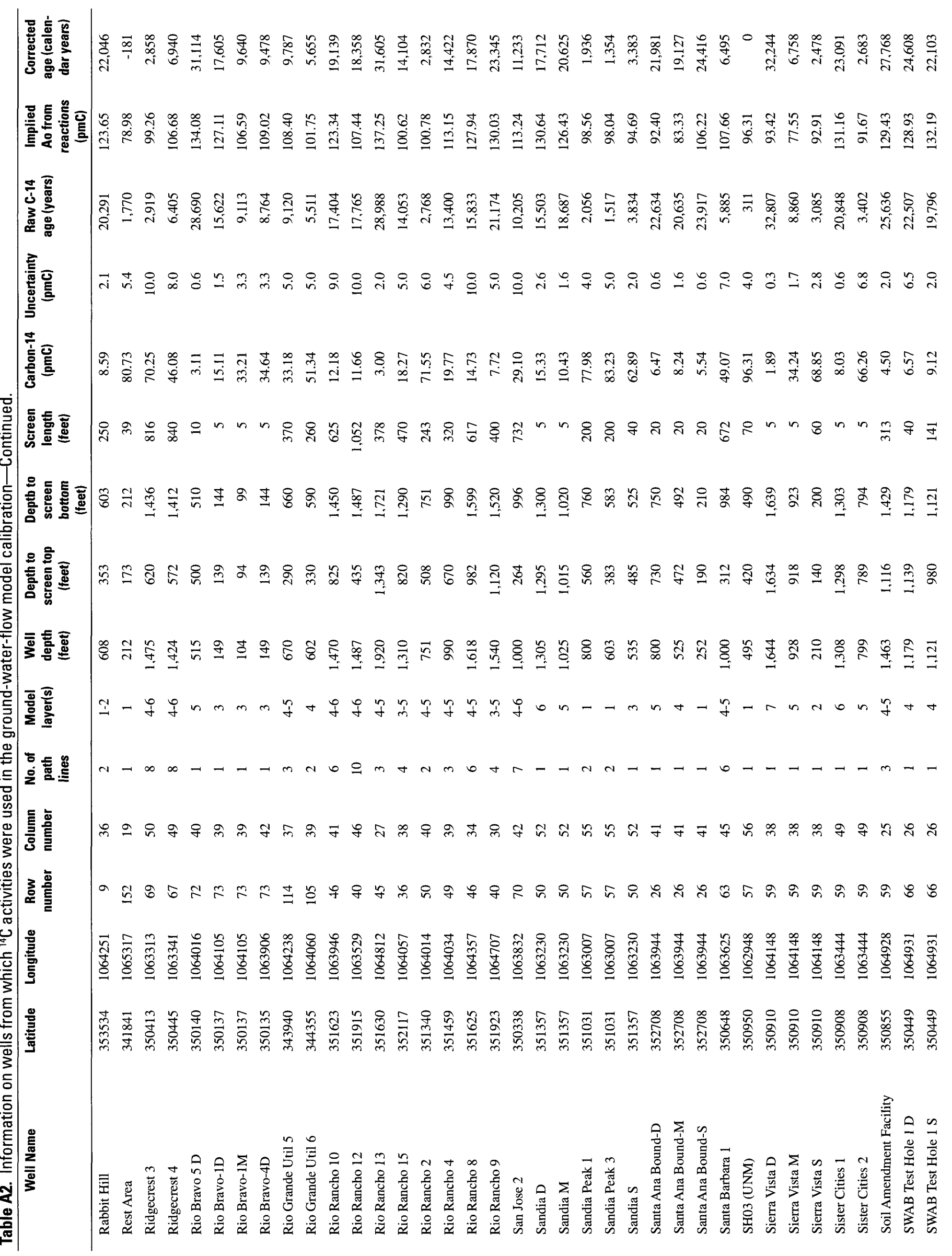




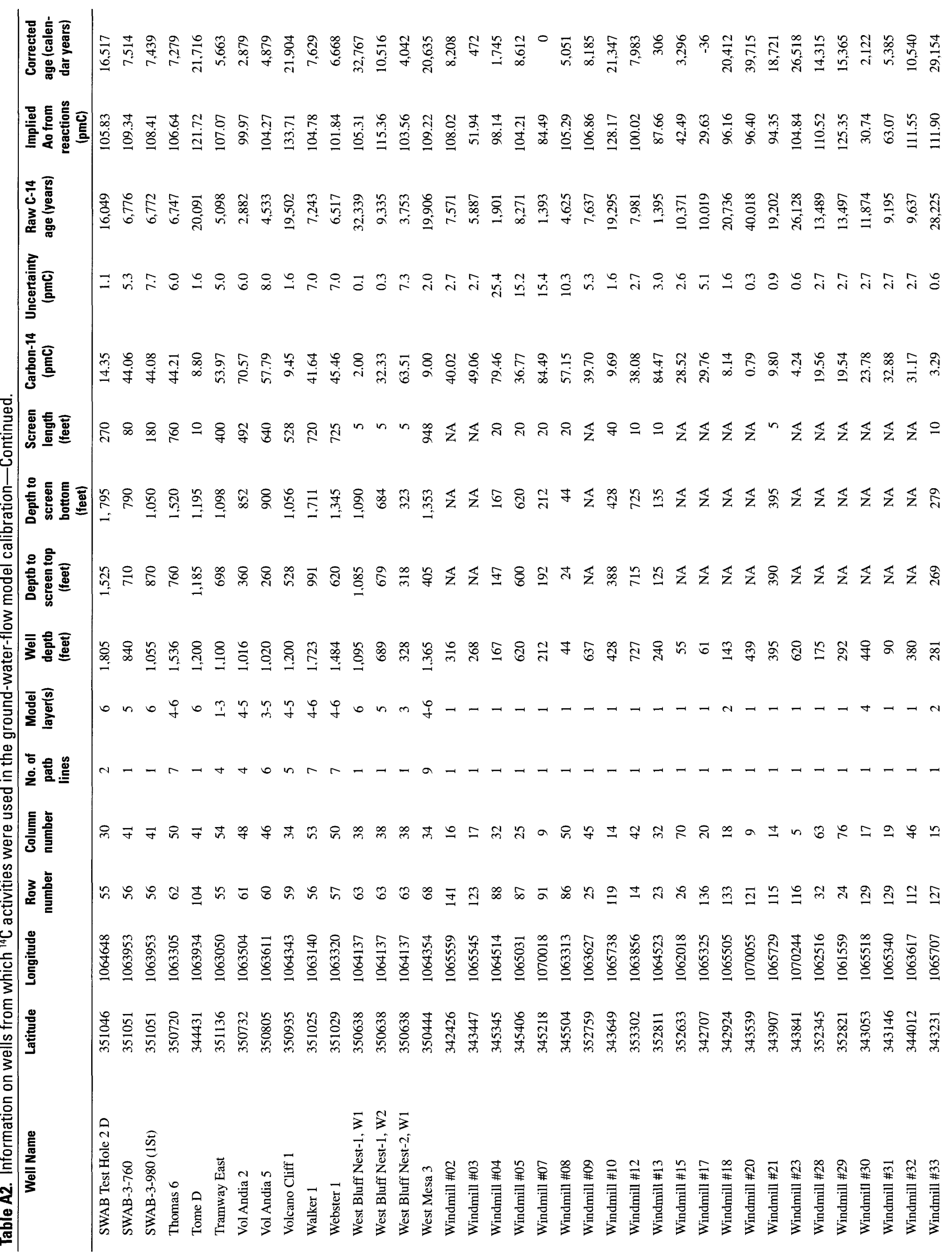




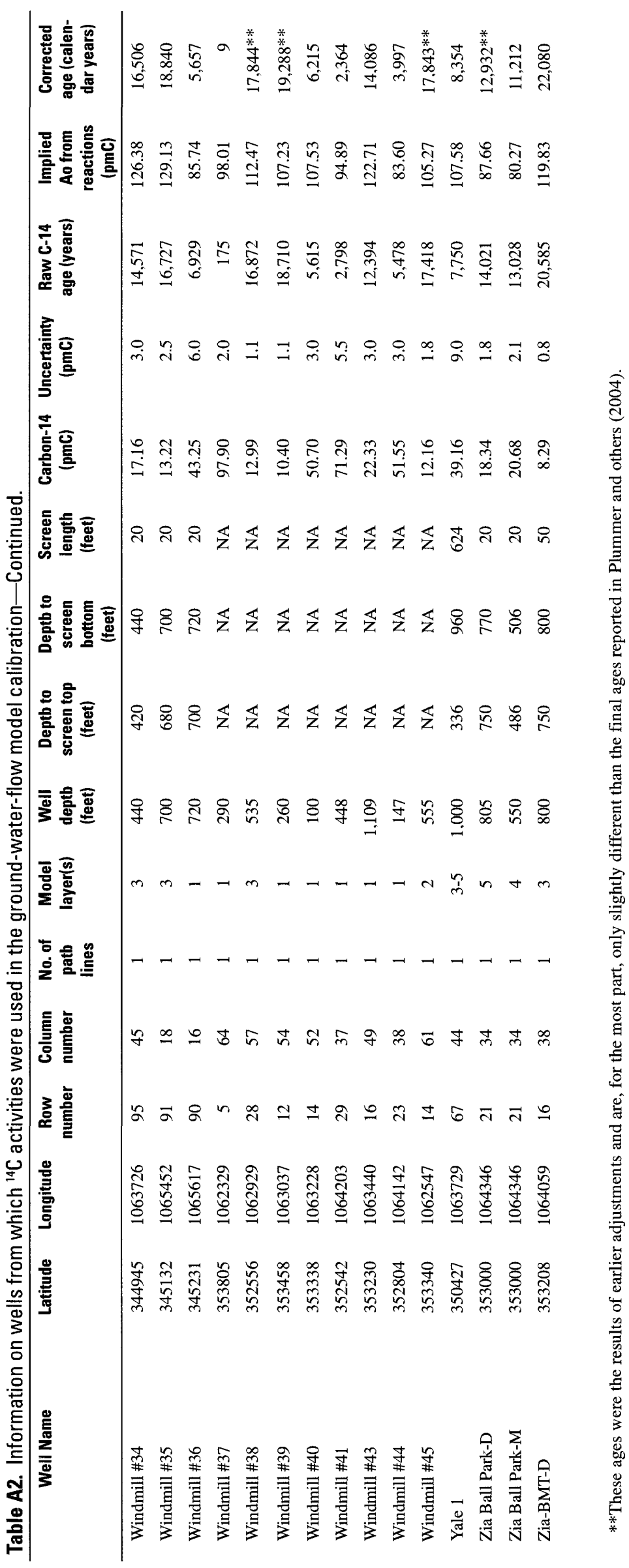


Table A3. Observed and simulated values of water levels (italics), ${ }^{14} \mathrm{C}$ activities, and hydrochemical zones (bold).

\begin{tabular}{|c|c|c|c|c|c|c|c|c|c|c|c|}
\hline Well name & $\begin{array}{c}\text { Ob- } \\
\text { served } \\
\text { value }\end{array}$ & $\begin{array}{l}\text { Simu- } \\
\text { lated } \\
\text { value }\end{array}$ & $\begin{array}{l}\text { Re- } \\
\text { sidual }\end{array}$ & $\begin{array}{c}\text { sqrt } \\
\text { (weight) }\end{array}$ & $\begin{array}{l}\text { Weighted } \\
\text { residual }\end{array}$ & Well name & $\begin{array}{l}\text { Observed } \\
\text { value* }^{*}\end{array}$ & $\begin{array}{l}\text { Simu- } \\
\text { lated } \\
\text { value }\end{array}$ & Residual & $\begin{array}{c}\text { sqrt } \\
\text { (weight) }\end{array}$ & $\begin{array}{l}\text { Weighted } \\
\text { residual }\end{array}$ \\
\hline Domestic \#12 & 183 & 199.5 & -16.5 & 0.40 & -6.6 & 1950 LL west 3 & 183 & 193.4 & -10.4 & 0.17 & -1.7 \\
\hline Domestic \#10 & 125 & 143.3 & -18.3 & 0.40 & -7.3 & 1950 LL east 2 & 179 & 180.8 & -1.8 & 0.17 & -0.3 \\
\hline Domestic \#06 & 155 & 152.9 & 2.1 & 0.40 & 0.8 & 1950 LL west 4 & 394 & 264.3 & 129.7 & 0.17 & 21.6 \\
\hline Domestic \#13 & 190 & 205.3 & -15.3 & 0.40 & -6.1 & 1950 LL sout 2 & 170 & 175.2 & -5.2 & 0.17 & -0.9 \\
\hline Domestic \#20 & 180 & 193.9 & -13.9 & 0.40 & -5.6 & 1950 Belen $n 1$ & 165 & 171.0 & -6.0 & 0.14 & -0.9 \\
\hline Domestic \#11 & 170 & 143.4 & 26.6 & 0.40 & 10.6 & 1950 Belen $n 2$ & 161 & 167.4 & -6.4 & 0.20 & -1.3 \\
\hline Domestic \#09 & 100 & 110.5 & -10.5 & 0.40 & -4.2 & 1950 Belen n3 & 162 & 168.7 & -6.7 & 0.17 & -1.1 \\
\hline PP Well \#05 & 88 & 83.9 & 4.2 & 0.40 & 1.7 & 1950 Belen $n 4$ & 164 & 173.8 & -9.8 & 0.17 & -1.6 \\
\hline Domestic \#08 & 90 & 107.6 & -17.6 & 0.40 & -7.0 & 1950 Belen e1 & 157 & 160.0 & -3.0 & 0.17 & -0.5 \\
\hline PP Well \#08 & 88 & 103.8 & -15.8 & 1.00 & -15.8 & 1950 Belen e2 & 171 & 171.2 & -0.2 & 0.17 & -0.0 \\
\hline$R G$ Utility 5 & 150 & 157.1 & -7.0 & 0.29 & -2.0 & 1950 Puerco 1 & 179 & 185.6 & -6.6 & 0.17 & -1.1 \\
\hline Grasslands $R$ & 200 & 203.6 & -3.6 & 1.00 & -3.6 & 1950 Belen e3 & 160 & 158.3 & 1.7 & 0.17 & 0.3 \\
\hline Belen Airport S & 155 & 155.5 & -0.5 & 1.00 & -0.5 & Windmill \#23 & 206 & 323.1 & -117.1 & 0.17 & -19.5 \\
\hline McLaughlin T & 149 & 145.1 & 3.9 & 1.00 & 3.9 & 1950 Belen s1 & 150 & 142.7 & 7.3 & 0.17 & 1.2 \\
\hline Sevilleta $V$ & 73 & 60.8 & 12.2 & 1.00 & 12.2 & 1950 Belen $w 1$ & 155 & 153.4 & 1.6 & 0.17 & 0.3 \\
\hline NM Highway & 82 & 55.0 & 27.0 & 0.40 & 10.8 & 1950 Belen $s 2$ & 127 & 134.7 & -7.7 & 0.20 & -1.5 \\
\hline Domestic \#35 & 77 & 78.4 & -1.4 & 0.40 & -0.5 & 1950 Belen $w 2$ & 148 & 140.4 & 7.6 & 0.17 & 1.3 \\
\hline Domestic \#36 & 130 & 143.4 & -13.4 & 0.40 & -5.3 & 1950 Belen s3 & 128 & 126.4 & 1.6 & 0.17 & 0.3 \\
\hline Domestic \#29 & 185 & 198.2 & -13.2 & 0.40 & -5.3 & Windmill \#31 & 159 & 154.0 & 5.0 & 0.17 & 0.8 \\
\hline Windmill \#33 & 158 & 145.4 & 12.6 & 0.40 & 5.0 & 1950 Belen s4 & 114 & 113.8 & 0.2 & 0.20 & 0.0 \\
\hline Windmill \#17 & 101 & 88.8 & 12.2 & 0.40 & 4.9 & 1950 Belen s 5 & 110 & 111.3 & -1.3 & 0.20 & -0.3 \\
\hline Windmill \#18 & 126 & 124.7 & 1.3 & 0.40 & 0.5 & $1950 \mathrm{Abo} I$ & 138 & 128.1 & 9.9 & 0.17 & 1.6 \\
\hline Domestic \#32 & 60 & 52.4 & 7.6 & 0.40 & 3.0 & $1950 \mathrm{Abo} 2$ & 135 & 120.1 & 14.9 & 0.17 & 2.5 \\
\hline Windmill \#03 & 160 & 156.1 & 3.9 & 0.40 & 1.6 & 1950 Bernardo & 77 & 84.4 & -7.4 & 0.17 & -1.2 \\
\hline Windmill \#10 & 167 & 170.0 & -3.0 & 0.40 & -1.2 & 1950 N LaJoya & 68 & 61.7 & 6.3 & 0.14 & 0.9 \\
\hline Cerro $\mathrm{CO} P W$ & 287 & 247.9 & 39.1 & 0.29 & 11.2 & Windmill \#101 & 234 & 430.1 & -196.1 & 0.14 & -28.0 \\
\hline PP Well \#16 & 249 & 250.9 & -1.9 & 0.29 & -0.6 & Windmill \#47 & 194 & 211.7 & -17.7 & 0.17 & -2.9 \\
\hline Soil A Facility & 294 & 293.4 & 0.6 & 0.29 & 0.2 & Windmill \#48 & 191 & 207.9 & -16.9 & 0.17 & -2.8 \\
\hline PP Well \#01 & 241 & 268.0 & -27.0 & 0.29 & -7.7 & Windmill \#49 & 213 & 210.8 & 2.2 & 0.20 & 0.4 \\
\hline Tome Deep & 175 & 185.1 & -10.1 & 1.00 & -10.1 & Windmill \#50 & 212 & 220.8 & -8.8 & 0.20 & -1.8 \\
\hline Windmill \#46 & 630 & 533.8 & 96.2 & 0.04 & 3.9 & Windmill \#51 & 217 & 223.2 & -6.2 & 0.17 & -1.0 \\
\hline Isleta Deep & 232 & 236.9 & -4.9 & 1.00 & -4.9 & Windmill \#04 & 216 & 215.9 & 0.1 & 0.17 & 0.01 \\
\hline$M R N-I$ & 290 & 257.6 & 32.4 & 0.14 & 4.6 & Windmill \#52 & 200 & 211.9 & -11.9 & 0.20 & -2.4 \\
\hline 98th street D & 250 & 279.2 & -29.2 & 1.00 & -29.2 & Windmill \#53 & 235 & 233.8 & 1.2 & 0.20 & 0.2 \\
\hline 1950 LL cent 1 & 203 & 208.7 & -5.7 & 0.20 & -1.1 & Windmill \#54 & 230 & 233.2 & -3.2 & 0.25 & -0.8 \\
\hline 1950 LL cent 2 & 193 & 202.0 & -9.0 & 0.17 & -1.5 & Windmill \#55 & 254 & 232.8 & 21.2 & 0.20 & 4.2 \\
\hline 1950 LL cent 3 & 195 & 199.6 & -4.6 & 0.14 & -0.7 & Windmill \#56 & 230 & 240.0 & -10.0 & 0.25 & -2.5 \\
\hline 1950 LL west 1 & 191 & 203.7 & -12.7 & 0.17 & -2.1 & Windmill \#57 & 237 & 237.3 & -0.3 & 0.20 & -0.1 \\
\hline 1950 LL west 2 & 324 & 292.1 & 31.9 & 0.17 & 5.3 & Windmill \#58 & 236 & 227.3 & 8.7 & 0.20 & 1.7 \\
\hline 1950 LL east 1 & 193 & 200.2 & -7.2 & 0.17 & -1.2 & PP Well \#02 & 218 & 218.1 & -0.1 & 0.17 & -0.01 \\
\hline 1950 LL cent 4 & 179 & 186.8 & -7.8 & 0.17 & -1.3 & Windmill \#35 & 193 & 207.3 & -14.3 & 0.20 & -2.9 \\
\hline 1950 LL sout 1 & 180 & 185.3 & -5.3 & 0.17 & -0.19 & Windmill \#59 & 183 & 220.1 & -37.1 & 0.20 & -7.4 \\
\hline
\end{tabular}


Table A3. Observed and simulated values of water levels (italics), ${ }^{14} \mathrm{C}$ activities, and hydrochemical zones (bold) —Continued.

\begin{tabular}{|c|c|c|c|c|c|c|c|c|c|c|c|}
\hline Well name & $\begin{array}{c}\text { Ob- } \\
\text { served } \\
\text { value* }^{*}\end{array}$ & $\begin{array}{l}\text { Simu- } \\
\text { lated } \\
\text { value }\end{array}$ & $\begin{array}{l}\text { Re- } \\
\text { sidual }\end{array}$ & $\begin{array}{c}\text { sqrt } \\
\text { (weight) }\end{array}$ & $\begin{array}{l}\text { Weighted } \\
\text { residual }\end{array}$ & Well name & $\begin{array}{c}\text { Observed } \\
\text { value* }^{*}\end{array}$ & $\begin{array}{l}\text { Simu- } \\
\text { lated } \\
\text { value }\end{array}$ & Residual & $\begin{array}{c}\text { sqrt } \\
\text { (weight) }\end{array}$ & $\begin{array}{l}\text { Weighted } \\
\text { residual }\end{array}$ \\
\hline Windmill \#34 & 182 & 209.4 & -27.4 & 0.20 & -5.5 & 1950 WAtrsc3 & 285 & 287.2 & -2.2 & 0.17 & -0.4 \\
\hline Windmill \#60 & 193 & 206.5 & -13.5 & 0.20 & -2.7 & 1950 Burton 5 & 299 & 305.5 & -6.5 & 0.17 & -1.1 \\
\hline Windmill \#05 & 221 & 212.8 & 8.2 & 0.20 & 1.6 & 1950 NKirtland & 303 & 309.4 & -6.4 & 0.17 & -1.1 \\
\hline Windmill \#61 & 328 & 278.8 & 49.2 & 0.20 & 9.8 & 19504-Hills & 334 & 391.5 & -57.5 & 0.14 & -8.2 \\
\hline Windmill \#62 & 365 & 323.2 & 41.8 & 0.20 & 8.4 & 1950 WKirtland & 297 & 296.4 & 0.6 & 0.14 & 0.1 \\
\hline Windmill \#63 & 319 & 291.8 & 27.3 & 0.20 & 5.5 & 1950 Leavitt & 270 & 272.8 & -2.8 & 0.17 & -0.5 \\
\hline Windmill \#64 & 229 & 235.8 & -6.8 & 0.20 & -1.4 & 1950 SKirtland & 295 & 298.6 & -3.6 & 0.10 & -0.4 \\
\hline Windmill \#65 & 229 & 229.6 & -0.6 & 0.20 & -0.1 & 1950 Rio Bravo & 272 & 275.5 & -3.5 & 0.17 & -0.6 \\
\hline Windmill \#66 & 192 & 215.2 & -23.2 & 0.20 & -4.6 & 1950 VGP-1 & 258 & 263.6 & -5.6 & 0.17 & -0.9 \\
\hline Windmill \#07 & 341 & 317.2 & 23.8 & 0.20 & 4.8 & 1940 Gntry 103 & 305 & 285.6 & 19.4 & 0.20 & 3.9 \\
\hline Windmill \#67 & 228 & 208.6 & 19.4 & 0.20 & 3.9 & 1950 N Isleta & 246 & 246.7 & -0.7 & 0.14 & -0.1 \\
\hline Windmill \#68 & 271 & 229.3 & 41.7 & 0.20 & 8.3 & 1950 Islta Nest & 241 & 242.0 & -1.0 & 0.14 & -0.1 \\
\hline Corrales $N$ & 371 & 370.0 & 1.0 & 0.20 & 0.2 & Windmill \#69 & 375 & 370.8 & 4.2 & 0.25 & 1.0 \\
\hline Corrales $S$ & 362 & 363.5 & -1.5 & 0.17 & -0.3 & Sandia ECW & 409 & 380.8 & 28.2 & 0.20 & 5.6 \\
\hline Windmill \#100 & 344 & 371.8 & -27.8 & 0.17 & -4.6 & Windmill \#70 & 378 & 386.7 & -8.7 & 0.17 & -1.5 \\
\hline 1950 H Ridge & 338 & 348.5 & -10.5 & 0.17 & -1.8 & Windmill \#71 & 423 & 410.9 & 12.1 & 0.20 & 2.4 \\
\hline 1950 Paseo2n & 338 & 343.7 & -5.7 & 0.17 & -1.0 & Windmill \#72 & 413 & 421.1 & -8.1 & 0.20 & -1.6 \\
\hline 1950 Paseo $2 s$ & 334 & 337.4 & -3.4 & 0.17 & -0.6 & Windmill \#73 & 490 & 453.1 & 36.9 & 0.20 & 7.4 \\
\hline $1950 S W A B 3$ & 332 & 335.9 & -3.9 & 0.17 & -0.7 & Windmill \#74 & 435 & 466.0 & -31.0 & 0.25 & -7.8 \\
\hline 1950 Nor Este & 340 & 349.6 & -9.6 & 0.17 & -1.6 & Windmill \#75 & 595 & 487.1 & 107.9 & 0.20 & 21.6 \\
\hline 1950 Summer & 974 & 928.6 & 45.4 & 0.17 & 7.6 & Windmill \#76 & 562 & 488.4 & 73.6 & 0.20 & 14.7 \\
\hline 1950 Paseo $2 v$ & 328 & 333.5 & -5.5 & 0.17 & -0.9 & Windmill \#77 & 618 & 508.8 & 109.2 & 0.20 & 21.8 \\
\hline Domestic \#39 & 321 & 328.5 & -7.5 & 0.17 & -1.3 & Windmill \#78 & 557 & 503.5 & 53.5 & 0.20 & 10.7 \\
\hline Domestic \#27 & 317 & 323.2 & -6.2 & 0.17 & -1.0 & Windmill \#09 & 490 & 518.0 & -28.0 & 0.20 & -5.6 \\
\hline 1950 MntanoN & 323 & 329.7 & -6.7 & 0.17 & -1.1 & Windmill \#79 & 651 & 546.7 & 104.3 & 0.25 & 26.1 \\
\hline 1950 SisterC & 318 & 317.4 & 0.6 & 0.17 & 0.1 & Windmill \#80 & 505 & 561.5 & -56.5 & 0.25 & -14.1 \\
\hline 1950 Pndrosa & 318 & 329.2 & -11.3 & 0.17 & -1.9 & Windmill \#81 & 446 & 470.9 & -24.9 & 0.20 & -5.0 \\
\hline 1950 Lyndckr & 321 & 316.8 & 4.2 & 0.17 & 0.7 & San Felipe B & 570 & 601.1 & -31.1 & 0.17 & -5.2 \\
\hline 1950 Sierra $V$ & 310 & 319.3 & -9.3 & 0.17 & -1.6 & Windmill \#82 & 434 & 469.5 & -35.5 & 0.17 & -5.9 \\
\hline 1950 Mntano4 & 312 & 315.8 & -3.8 & 0.17 & -0.6 & Windmill \#83 & 492 & 518.9 & -27.0 & 0.25 & -6.7 \\
\hline 1950 Thomas & 316 & 316.8 & -0.8 & 0.17 & -0.1 & Windmill \#84 & 509 & 561.2 & -52.2 & 0.20 & -10.5 \\
\hline $1950 \mathrm{Luz}$ Sol & 313 & 315.6 & -2.6 & 0.17 & -0.4 & Windmill \#85 & 572 & 607.6 & -35.6 & 0.20 & -7.1 \\
\hline 1950 Wmath & 316 & 322.6 & -6.6 & 0.17 & -1.1 & Windmill \#86 & 529 & 542.6 & -13.6 & 0.25 & -3.4 \\
\hline 1950 Emath & 943 & 939.3 & 3.7 & 0.17 & 0.6 & Windmill \#87 & 494 & 595.5 & -101.5 & 0.17 & -16.9 \\
\hline 1950 Voland & 315 & 315.9 & -0.9 & 0.17 & -0.2 & Windmill \#88 & 474 & 533.7 & -59.7 & 0.17 & -9.9 \\
\hline 1950 Sbarb & 313 & 315.8 & -2.8 & 0.17 & -0.5 & Windmill \#89 & 494 & 554.6 & -60.6 & 0.17 & -10.1 \\
\hline 1950 WBluff & 300 & 303.4 & -3.4 & 0.17 & -0.6 & Windmill \#90 & 727 & 720.0 & 7.0 & 0.17 & 1.2 \\
\hline 1950 Charls4 & 311 & 315.7 & -4.7 & 0.17 & -0.8 & Windmill \#45 & 439 & 545.5 & -106.5 & 0.17 & -17.8 \\
\hline 1950 Smath & 310 & 316.9 & -6.9 & 0.17 & -1.1 & Windmill \#91 & 587 & 616.5 & -29.5 & 0.17 & -4.9 \\
\hline $1950 \mathrm{Del}$ Sol & 302 & 315.2 & -13.2 & 0.17 & -2.2 & Windmill \#92 & 733 & 649.6 & 83.4 & 0.17 & 13.9 \\
\hline 1950 WMesa3 & 286 & 283.8 & 2.2 & 0.14 & 0.3 & Rabbit Hill & 903 & 874.1 & 28.9 & 0.20 & 5.8 \\
\hline 1950 ORL-2 & 286 & 294.4 & -8.4 & 0.17 & -1.4 & Windmill \#41 & 572 & 503.6 & 68.4 & 0.20 & 13.7 \\
\hline
\end{tabular}


Table A3. Observed and simulated values of water levels (italics), ${ }^{14} \mathrm{C}$ activities, and hydrochemical zones (bold) - Continued.

\begin{tabular}{|c|c|c|c|c|c|c|c|c|c|c|c|}
\hline Well Name & $\begin{array}{c}\text { Ob- } \\
\text { served } \\
\text { value }\end{array}$ & $\begin{array}{l}\text { Simu- } \\
\text { lated } \\
\text { value }\end{array}$ & $\begin{array}{c}\text { Re- } \\
\text { sidual }\end{array}$ & $\begin{array}{c}\text { sqrt } \\
\text { (weight) }\end{array}$ & $\begin{array}{l}\text { Weighted } \\
\text { residual }\end{array}$ & Well Name & $\begin{array}{l}\text { Observed } \\
\text { value }^{*}\end{array}$ & $\begin{array}{l}\text { Simu- } \\
\text { lated } \\
\text { value }\end{array}$ & Residual & $\begin{array}{c}\text { sqrt } \\
\text { (weight) }\end{array}$ & $\begin{array}{c}\text { Weighted } \\
\text { residual }\end{array}$ \\
\hline PP Well \#14 & 735 & 667.1 & 67.9 & 0.20 & 13.6 & Domestic \#21 & 10.91 & 0.02 & 10.89 & 1.00 & 10.89 \\
\hline Windmill \#93 & 735 & 701.1 & 33.9 & 0.25 & 8.5 & Belen-4 & 14.55 & 11.22 & 3.33 & 0.20 & 0.67 \\
\hline Windmill \#94 & 744 & 667.8 & 76.2 & 0.20 & 15.3 & Belen-5 & 16.37 & 0.93 & 15.44 & 0.20 & 3.09 \\
\hline Windmill \#95 & 670 & 596.5 & 73.5 & 0.20 & 14.7 & Windmill \#02 & 40.02 & 36.79 & 3.23 & 1.00 & 3.23 \\
\hline Windmill \#43 & 578 & 571.2 & 6.8 & 0.20 & 1.4 & Burton2 & 47.73 & 52.02 & -4.29 & 0.20 & -0.86 \\
\hline Windmill \#96 & 653 & 715.8 & -62.8 & 0.25 & -15.7 & Burton5 & 44.70 & 23.01 & 21.60 & 0.20 & 4.32 \\
\hline Windmill \#97 & 733 & 707.1 & 25.9 & 0.20 & 5.2 & CEPO-02 & 21.32 & 22.92 & -1.60 & 1.00 & -1.60 \\
\hline Windmill \#98 & 822 & 777.7 & 44.3 & 0.20 & 8.9 & CerroCo-PW & 7.35 & 0.00 & 7.35 & 0.20 & 1.47 \\
\hline Windmill \#42 & 655 & 555.5 & 99.5 & 0.17 & 16.6 & Charles-4 & 51.40 & 46.51 & 4.89 & 0.20 & 0.98 \\
\hline Windmill \#99 & 453 & 499.4 & -46.4 & 0.17 & -7.7 & Windmill \#18 & 8.12 & 4.91 & 3.21 & 1.00 & 3.21 \\
\hline NE Well \#01 & 567 & 572.3 & -5.3 & 0.17 & -0.9 & Windmill \#17 & 29.63 & 28.01 & 1.62 & 1.00 & 1.62 \\
\hline Windmill \#37 & 734 & 638.6 & 95.4 & 0.17 & 15.9 & PP Well \#2 & 96.37 & 97.15 & -0.78 & 0.20 & -0.16 \\
\hline NE Well \#02 & 581 & 574.6 & 6.4 & 0.17 & 1.1 & PP Well \#4 & 51.93 & 59.06 & -7.13 & 1.00 & -7.13 \\
\hline NE Well \#03 & 679 & 628.3 & 50.7 & 0.17 & 8.5 & Windmill \#37 & 97.90 & 48.60 & 49.30 & 1.00 & 49.30 \\
\hline NE Well \#04 & 701 & 600.4 & 100.6 & 0.17 & 16.8 & PP Well \#03 & 82.55 & 80.43 & 2.13 & 1.00 & 2.13 \\
\hline Solar Well & 711 & 590.2 & 120.8 & 0.17 & 20.1 & College-2 & 5.31 & 6.49 & -1.18 & 0.20 & -0.24 \\
\hline$R R$ Well 2 & 321 & 339.6 & -18.6 & 0.17 & -3.1 & Windmill \#20 & 0.79 & 0.00 & 0.79 & 1.00 & 0.79 \\
\hline RR Well 7 & 284 & 355.4 & -71.4 & 0.17 & -11.9 & Coronado-1 & 32.77 & 14.79 & 17.98 & 0.20 & 3.60 \\
\hline$R R$ Well 8 & 297 & 368.2 & -71.2 & 0.17 & -11.9 & Domestic \#03 & 21.00 & 12.10 & 8.90 & 1.00 & 8.90 \\
\hline$R R$ Well 9 & 322 & 390.5 & -68.5 & 0.17 & -11.4 & Del-Sol-1-D & 6.20 & 7.86 & -1.66 & 1.00 & -1.66 \\
\hline RR Well 13 & 304 & 370.2 & -66.2 & 0.17 & -11.0 & Del-Sol-2-M & 13.65 & 15.56 & -1.91 & 1.00 & -1.91 \\
\hline RR Well 15 & 369 & 400.4 & -31.4 & 0.17 & -5.2 & Del-Sol-3-S & 62.21 & 36.21 & 26.00 & 1.00 & 26.00 \\
\hline Tierra $M D$ & 405 & 420.2 & -15.2 & 0.40 & -6.1 & Eubank-1 & 61.33 & 56.53 & 4.80 & 1.00 & 4.80 \\
\hline Domestic \#37 & 457 & 451.0 & 6.0 & 0.40 & 2.4 & Windmill \#21 & 9.21 & 0.69 & 8.52 & 1.00 & 8.52 \\
\hline Domestic \#38 & 551 & 562.8 & -11.8 & 0.40 & -4.7 & Garfield-1 & 12.38 & 10.95 & 1.43 & 1.00 & 1.43 \\
\hline$S W A B 2 D$ & 310 & 316.3 & -6.3 & 0.40 & -2.5 & Garfield-2 & 22.08 & 11.86 & 10.22 & 1.00 & 10.22 \\
\hline$S W A B 2 S$ & 300 & 317.9 & -18.0 & 0.40 & -7.2 & Garfield-3 & 81.84 & 97.45 & -15.61 & 1.00 & -15.61 \\
\hline Volc Cliffs $H$ & 310 & 323.0 & -13.0 & 0.40 & -5.2 & Domestic \#22 & 80.70 & 77.11 & 3.59 & 1.00 & 3.59 \\
\hline$S W A B 3 D$ & 312 & 322.8 & -10.8 & 0.40 & -4.3 & Domestic \#05 & 27.00 & 1.33 & 25.67 & 1.00 & 25.67 \\
\hline$S W A B 3 S$ & 318 & 327.5 & -9.5 & 0.40 & -3.8 & Gonzales-1 & 47.04 & 28.58 & 18.46 & 0.20 & 3.69 \\
\hline$S W A B I$ & 263 & 274.2 & -11.2 & 0.40 & -4.5 & Domestic \#06 & 36.45 & 40.20 & -3.75 & 1.00 & -3.75 \\
\hline Domestic \#31 & 555 & 388.1 & 166.9 & 0.14 & 23.8 & Doemstic \#07 & 97.48 & 78.08 & 19.40 & 1.00 & 19.40 \\
\hline 4-Hills-I & 93.95 & 72.16 & 21.79 & 1.00 & 21.79 & Windmill \#03 & 49.06 & 23.79 & 25.27 & 1.00 & 25.27 \\
\hline PP Well \#15 & 81.88 & 54.39 & 27.49 & 0.20 & 5.50 & Windmill \#23 & 4.23 & 0.00 & 4.23 & 1.00 & 4.23 \\
\hline 98thSt-DP & 0.13 & 5.85 & -5.72 & 1.00 & -5.72 & HuntRidg-11 & 24.66 & 5.63 & 19.03 & 1.00 & 19.03 \\
\hline 98thSt-MD & 3.69 & 6.59 & -2.90 & 1.00 & -2.90 & HuntRidg-12 & 60.14 & 1.05 & 59.09 & 1.00 & 59.09 \\
\hline 98thSt-MS & 0.79 & 1.75 & -0.96 & 1.00 & -0.96 & HuntRidg-21 & 72.13 & 64.06 & 8.07 & 1.00 & 8.07 \\
\hline 98thSt-SH & 6.37 & 0.11 & 6.26 & 1.00 & 6.26 & PP Well \#19 & 54.77 & 13.33 & 41.44 & 0.20 & 8.29 \\
\hline PP Well \#1 & 5.47 & 0.09 & 5.39 & 0.20 & 1.08 & Windmill \#36 & 43.40 & 26.46 & 16.94 & 1.00 & 16.94 \\
\hline PP Well \#16 & 9.12 & 7.36 & 1.77 & 0.20 & 0.35 & Windmill \#34 & 17.17 & 32.53 & -15.36 & 1.00 & -15.36 \\
\hline PP Well \#17 & 79.29 & 73.74 & 5.56 & 1.00 & 5.56 & Windmill \#04 & 79.46 & 71.99 & 7.47 & 1.00 & 7.47 \\
\hline Windmill \#15 & 28.30 & 33.19 & -4.89 & 1.00 & -4.89 & Windmill \#35 & 13.20 & 9.11 & 4.09 & 1.00 & 4.09 \\
\hline
\end{tabular}


Table A3. Observed and simulated values of water levels (italics), ${ }^{14} \mathrm{C}$ activities, and hydrochemical zones (bold) —Continued.

\begin{tabular}{|c|c|c|c|c|c|c|c|c|c|c|c|}
\hline Well Name & $\begin{array}{c}\text { Ob- } \\
\text { served } \\
\text { value* }^{*}\end{array}$ & $\begin{array}{l}\text { Simu- } \\
\text { lated } \\
\text { value }\end{array}$ & $\begin{array}{c}\text { Re- } \\
\text { sidual }\end{array}$ & $\begin{array}{c}\text { sqrt } \\
\text { (weight) }\end{array}$ & $\begin{array}{l}\text { Weighted } \\
\text { residual }\end{array}$ & Well Name & $\begin{array}{l}\text { Observed } \\
\text { value* }\end{array}$ & $\begin{array}{l}\text { Simu- } \\
\text { lated } \\
\text { value }\end{array}$ & Residual & $\begin{array}{c}\text { sqrt } \\
\text { (weight) }\end{array}$ & $\begin{array}{c}\text { Weighted } \\
\text { residual }\end{array}$ \\
\hline Isleta D & 2.71 & 0.42 & 2.29 & 1.00 & 2.29 & NMUtility-4 & 7.18 & 17.35 & -10.17 & 0.20 & -2.04 \\
\hline Isleta MD & 35.76 & 2.09 & 33.67 & 1.00 & 33.67 & Nor-Este-1 & 7.64 & 12.21 & -4.57 & 1.00 & -4.57 \\
\hline Isleta MS & 72.32 & 86.47 & -14.15 & 1.00 & -14.15 & Nor-Este-2 & 16.70 & 14.17 & 2.53 & 1.00 & 2.53 \\
\hline Isleta $\mathrm{S}$ & 118.23 & 117.66 & 0.57 & 1.00 & 0.57 & Nor-Este-3 & 47.62 & 67.38 & -19.76 & 1.00 & -19.76 \\
\hline Domestic \#08 & 13.00 & 29.41 & -16.41 & 1.00 & -16.41 & PP Well \#07 & 62.74 & 43.72 & 19.02 & 0.20 & 3.80 \\
\hline PP Well \#23 & 93.79 & 36.49 & 57.30 & 0.20 & 11.46 & Open-Space & 55.15 & 33.40 & 21.75 & 1.00 & 21.75 \\
\hline Domestic \#09 & 31.10 & 18.91 & 12.19 & 1.00 & 12.19 & Domestic \#29 & 54.94 & 53.08 & 1.86 & 1.00 & 1.86 \\
\hline Kirtland-01 & 59.38 & 38.82 & 20.56 & 0.20 & 4.11 & Paseo-2D & 76.69 & 92.91 & -16.22 & 1.00 & -16.22 \\
\hline Kirtland-11 & 45.98 & 51.56 & -5.58 & 0.20 & -1.12 & Paseo-3D & 64.51 & 50.31 & 14.20 & 1.00 & 14.20 \\
\hline Kirtland-14 & 48.86 & 40.32 & 8.54 & 0.20 & 1.71 & PL-2 & 38.34 & 50.44 & -12.10 & 1.00 & -12.10 \\
\hline Leavitt 1 & 17.01 & 7.98 & 9.03 & 0.20 & 1.81 & Ponderos-1 & 42.45 & 44.18 & -1.73 & 0.20 & -0.35 \\
\hline Leyendecker & 72.84 & 30.51 & 42.33 & 0.20 & 8.47 & Rabbit-Hill & 8.59 & 46.75 & -38.16 & 1.00 & -38.16 \\
\hline Lincoln D & 13.80 & 5.07 & 8.73 & 1.00 & 8.73 & Domestic \#12 & 5.85 & 0.06 & 5.79 & 1.00 & 5.79 \\
\hline Lincoln M & 15.46 & 5.28 & 10.18 & 1.00 & 10.18 & Domestic \#30 & 5.28 & 30.99 & -25.71 & 1.00 & -25.71 \\
\hline Lincoln S & 29.64 & 14.23 & 15.41 & 1.00 & 15.41 & Rest-Area & 78.90 & 78.38 & 0.52 & 1.00 & 0.52 \\
\hline Domestic \#23 & 11.09 & 0.03 & 11.06 & 1.00 & 11.06 & Ridgcrest-3 & 70.25 & 37.52 & 32.73 & 1.00 & 32.73 \\
\hline Lomas-1 & 72.78 & 59.29 & 13.49 & 0.20 & 2.70 & Ridgcrest-4 & 45.53 & 30.73 & 14.80 & 1.00 & 14.80 \\
\hline Los-Lunas-3 & 27.55 & 72.89 & -45.34 & 0.20 & -9.07 & RioBravo-5D & 3.02 & 14.24 & -11.22 & 1.00 & -11.22 \\
\hline Los-Lunas-4 & 50.45 & 73.49 & -23.04 & 0.20 & -4.61 & RioBravo-1D & 15.11 & 92.49 & -77.38 & 1.00 & -77.38 \\
\hline Love-1 & 47.21 & 64.15 & -16.94 & 0.20 & -3.39 & RioBravo-1M & 33.21 & 64.53 & -31.32 & 1.00 & -31.32 \\
\hline Domestic \#10 & 54.73 & 30.05 & 24.68 & 1.00 & 24.68 & RioBravo-4D & 34.64 & 40.19 & -5.55 & 1.00 & -5.55 \\
\hline Domestic \#11 & 8.33 & 26.08 & -17.75 & 1.00 & -17.75 & RioGrUtil-5 & 33.18 & 5.84 & 27.34 & 0.20 & 5.47 \\
\hline Matheson-D & 35.35 & 16.74 & 18.61 & 1.00 & 18.61 & RioGrUtil-6 & 51.34 & 11.36 & 39.98 & 0.20 & 8.00 \\
\hline Matheson-M & 55.87 & 64.50 & -8.63 & 1.00 & -8.63 & Domestic \#31 & 35.55 & 59.98 & -24.43 & 1.00 & -24.43 \\
\hline Matheson-S & 64.88 & 73.06 & -8.18 & 1.00 & -8.18 & RioRanchol0 & 12.18 & 12.88 & -0.70 & 0.20 & -0.14 \\
\hline Domestic \#25 & 95.14 & 79.27 & 15.87 & 1.00 & 15.87 & RioRancho12 & 24.80 & 3.35 & 21.45 & 0.20 & 4.29 \\
\hline MesaDelSol-D & 5.99 & 1.75 & 4.24 & 1.00 & 4.24 & RioRancho13 & 3.00 & 31.13 & -28.13 & 0.20 & -5.63 \\
\hline MesaDelSol-M & 3.24 & 33.58 & -30.34 & 1.00 & -30.34 & RioRancho15 & 18.27 & 1.09 & 17.18 & 0.20 & 3.44 \\
\hline MesaDelSol-S & 33.36 & 32.05 & 1.31 & 1.00 & 1.31 & RioRancho02 & 67.18 & 1.01 & 66.17 & 0.20 & 13.23 \\
\hline Montano-6DP & 25.19 & 34.35 & -9.16 & 1.00 & -9.16 & RioRancho04 & 19.77 & 4.68 & 15.09 & 0.20 & 3.02 \\
\hline Montano-6MD & 37.95 & 5.08 & 32.87 & 1.00 & 32.87 & RioRancho08 & 14.73 & 20.17 & -5.44 & 0.20 & -1.09 \\
\hline Montano-6MS & 67.54 & 6.15 & 61.39 & 1.00 & 61.39 & RioRancho09 & 7.72 & 48.25 & -40.53 & 0.20 & -8.11 \\
\hline Montesa-M & 18.63 & 28.28 & -9.65 & 1.00 & -9.65 & Domestic \#32 & 10.82 & 0.00 & 10.82 & 1.00 & 10.82 \\
\hline Montesa-S & 52.51 & 42.70 & 9.81 & 1.00 & 9.81 & Domestic \#13 & 22.24 & 12.88 & 9.36 & 1.00 & 9.36 \\
\hline Domestic \#27 & 42.18 & 44.12 & -1.94 & 1.00 & -1.94 & Windmill \#05 & 36.77 & 0.00 & 36.77 & 1.00 & 36.77 \\
\hline MRN-1 & 42.08 & 65.89 & -23.81 & 1.00 & -23.81 & Windmill \#07 & 84.49 & 78.79 & 5.70 & 1.00 & 5.70 \\
\hline Domestic \#28 & 71.77 & 50.91 & 20.86 & 1.00 & 20.86 & Windmill \#08 & 57.15 & 24.63 & 32.52 & 1.00 & 32.52 \\
\hline PP Well \#05 & 7.46 & 0.00 & 7.46 & 1.00 & 7.46 & PP Well \#08 & 9.23 & 2.39 & 6.84 & 1.00 & 6.84 \\
\hline PP Well \#06 & 29.21 & 33.91 & -4.70 & 1.00 & -4.70 & PP Well \#20 & 74.94 & 41.12 & 33.82 & 0.20 & 6.76 \\
\hline NMUtility-1 & 13.81 & 11.13 & 2.68 & 0.20 & 0.54 & Windmill \#28 & 19.25 & 86.50 & -67.25 & 1.00 & -67.25 \\
\hline NMUtility-2 & 50.57 & 5.16 & 45.41 & 0.20 & 9.08 & PP Well \#21 & 58.04 & 31.37 & 26.67 & 0.20 & 5.33 \\
\hline NMUtility-3 & 15.58 & 17.48 & -1.90 & 0.20 & -0.38 & Windmill \#38 & 12.99 & 5.98 & 7.01 & 1.00 & 7.01 \\
\hline
\end{tabular}


Table A3. Observed and simulated values of water levels (italics), ${ }^{14} \mathrm{C}$ activities, and hydrochemical zones (bold)-Continued.

\begin{tabular}{|c|c|c|c|c|c|c|c|c|c|c|c|}
\hline Well Name & $\begin{array}{c}\text { Ob- } \\
\text { served } \\
\text { value* }\end{array}$ & $\begin{array}{l}\text { Simu- } \\
\text { lated } \\
\text { value }\end{array}$ & $\begin{array}{c}\text { Re- } \\
\text { sidual }\end{array}$ & $\begin{array}{c}\text { sqrt } \\
\text { (weight) }\end{array}$ & $\begin{array}{l}\text { Weighted } \\
\text { residual }\end{array}$ & Well Name & $\begin{array}{c}\text { Observed } \\
\text { value* }^{*}\end{array}$ & $\begin{array}{l}\text { Simu- } \\
\text { lated } \\
\text { value }\end{array}$ & Residual & $\begin{array}{c}\text { sqrt } \\
\text { (weight) }\end{array}$ & $\begin{array}{l}\text { Weighted } \\
\text { residual }\end{array}$ \\
\hline PP Well \#22 & 68.06 & 78.93 & -10.87 & 0.20 & -2.18 & Tome-D & 8.80 & 12.03 & -3.23 & 1.00 & -3.23 \\
\hline SanJose-2 & 29.10 & 30.30 & -1.20 & 0.20 & -0.24 & PP Well \#12 & 92.03 & 49.36 & 42.67 & 0.20 & 8.53 \\
\hline Domestic \#33 & 15.18 & 10.60 & 4.58 & 1.00 & 4.58 & Tramway-E & 53.97 & 81.04 & -27.07 & 0.20 & -5.41 \\
\hline Sandia-D & 15.33 & 6.08 & 9.25 & 1.00 & 9.25 & Domestic \#34 & 83.31 & 29.33 & 53.98 & 1.00 & 53.98 \\
\hline Sandia-M & 10.43 & 13.99 & -3.56 & 1.00 & -3.56 & Windmill \#33 & 3.27 & 0.13 & 3.14 & 1.00 & 3.14 \\
\hline SandiaPeak1 & 77.98 & 77.18 & 0.80 & 0.20 & 0.16 & VolAndia-2 & 70.57 & 33.96 & 36.61 & 0.20 & 7.32 \\
\hline SandiaPeak3 & 83.23 & 77.13 & 6.01 & 0.20 & 1.22 & VolAndia-5 & 57.78 & 61.23 & -3.45 & 0.20 & -0.69 \\
\hline Sandia-S & 62.89 & 60.67 & 2.22 & 1.00 & 2.22 & VolcanoCf-1 & 9.28 & 4.81 & 4.47 & 0.20 & 0.89 \\
\hline Windmill \#09 & 39.70 & 9.23 & 30.47 & 1.00 & 30.47 & Walker-1 & 41.64 & 29.39 & 12.25 & 0.20 & 2.45 \\
\hline SantaAna-B D & 6.47 & 18.32 & -11.85 & 1.00 & -11.85 & Webster-1 & 45.46 & 45.38 & 0.08 & 0.20 & 0.02 \\
\hline SantaAna-B M & 8.24 & 24.19 & -15.95 & 1.00 & -15.95 & WestBluf-11 & 2.00 & 0.28 & 1.72 & 1.00 & 1.72 \\
\hline SantaAna-B S & 5.54 & 20.49 & -14.95 & 1.00 & -14.95 & WestBluf-12 & 30.02 & 17.20 & 12.82 & 1.00 & 12.82 \\
\hline SantaBarb-1 & 49.07 & 49.39 & -0.32 & 0.20 & -0.06 & WestBluf-2I & 61.51 & 77.36 & -15.85 & 1.00 & -15.85 \\
\hline Windmill \#45 & 12.16 & 5.42 & 6.74 & 1.00 & 6.74 & West-Mesa-3 & 8.89 & 7.37 & 1.52 & 0.20 & 0.30 \\
\hline Windmill \#39 & 10.40 & 46.97 & -36.57 & 1.00 & -36.57 & Domestic \#20 & 24.66 & 8.85 & 15.81 & 1.00 & 15.81 \\
\hline Windmill \#29 & 19.21 & 20.52 & -1.31 & 1.00 & -1.31 & Yale-1 & 39.16 & 56.21 & -17.05 & 0.20 & -3.41 \\
\hline Domestic \#14 & 79.91 & 45.39 & 34.52 & 1.00 & 34.52 & Windmill \#12 & 38.08 & 18.22 & 19.86 & 1.00 & 19.86 \\
\hline Domestic \#15 & 11.62 & 20.31 & -8.69 & 1.00 & -8.69 & Windmill \#40 & 50.70 & 28.45 & 22.25 & 1.00 & 22.25 \\
\hline SH03(UNM) & 96.31 & 75.65 & 20.67 & 1.00 & 20.67 & Windmill \#41 & 71.29 & 47.58 & 23.71 & 1.00 & 23.71 \\
\hline SierVista-D & 1.89 & 2.44 & -0.55 & 1.00 & -0.55 & Windmill \#13 & 84.47 & 72.72 & 11.75 & 1.00 & 11.75 \\
\hline SierVista-M & 34.24 & 0.65 & 33.59 & 1.00 & 33.59 & Windmill \#43 & 22.33 & 32.24 & -9.91 & 1.00 & -9.91 \\
\hline SierVista-S & 68.85 & 79.09 & -10.24 & 1.00 & -10.24 & Windmill \#44 & 51.55 & 58.62 & -7.07 & 1.00 & -7.07 \\
\hline Domestic \#16 & 32.57 & 51.45 & -18.88 & 1.00 & -18.88 & Zia-Ball Park D & 18.34 & 1.09 & 17.25 & 0.20 & 3.45 \\
\hline Sister Cities 1 & 7.97 & 9.10 & -1.13 & 1.00 & -1.13 & Zia Ball Park M & 20.70 & 38.03 & -17.33 & 0.20 & -3.47 \\
\hline Sister Cities 2 & 64.72 & 37.57 & 27.15 & 1.00 & 27.15 & PP Well \#13 & 71.20 & 39.52 & 31.68 & 1.00 & 31.68 \\
\hline Soil-Amend & 4.50 & 4.16 & 0.34 & 0.20 & 0.07 & PP Well \#14 & 37.39 & 38.04 & -0.65 & 1.00 & -0.65 \\
\hline Windmill \#30 & 23.12 & 0.06 & 23.06 & 1.00 & 23.06 & Zia-BMT-D & 8.30 & 34.81 & -26.51 & 1.00 & -26.51 \\
\hline Windmill \#31 & 32.05 & 62.35 & -30.30 & 1.00 & -30.30 & rg2west & 2160 & 2790 & -630 & 0.05 & -28.64 \\
\hline Domestic \#18 & 66.42 & 76.22 & -9.80 & 1.00 & -9.80 & rg2east & 1350 & 668 & 682 & 0.07 & 48.71 \\
\hline SWAB-1-D & 6.57 & 5.81 & 0.76 & 1.00 & 0.76 & rg4west & 1890 & 3443 & -1553 & 0.05 & -81.74 \\
\hline SWAB-1-S & 9.12 & 6.51 & 2.61 & 1.00 & 2.61 & rg4east & 900 & 779 & 121 & 0.11 & 13.44 \\
\hline SWAB-2-D & 14.35 & 5.96 & 8.39 & 1.00 & 8.39 & rg6south & 500 & 502 & -2 & 0.20 & -0.40 \\
\hline SWAB3-760 & 44.06 & 22.97 & 21.09 & 1.00 & 21.09 & rp1north & 1800 & 1730 & 70 & 0.06 & 3.89 \\
\hline SWAB3-980 & 44.08 & 44.09 & -0.01 & 1.00 & -0.01 & rp2west & 540 & 599 & -59 & 0.20 & -11.80 \\
\hline Windmill \#32 & 30.54 & 18.52 & 12.02 & 1.00 & 12.02 & rp2east & 1800 & 2138 & -338 & 0.06 & -18.78 \\
\hline Thomas- 6 & 44.21 & 40.41 & 3.80 & 0.20 & 0.76 & rp3west & 1440 & 1794 & -354 & 0.07 & -25.29 \\
\hline Windmill \#10 & 9.70 & 0.58 & 9.12 & 1.00 & 9.12 & & & & & & \\
\hline
\end{tabular}

*Water-level observed values are equal to the water-level altitude values (table $\mathrm{A} 1$ ) minus 4,650 feet. $\quad{ }^{14} \mathrm{C}$ activity observed values are equal to the percent modern carbon values in table A2. Geochemical zone observed values are the estimated number of path lines that would originate from the river (table 2 ). 


\section{APPENDIX B. Computer Programs}

A1. PROGRAM Prep.f

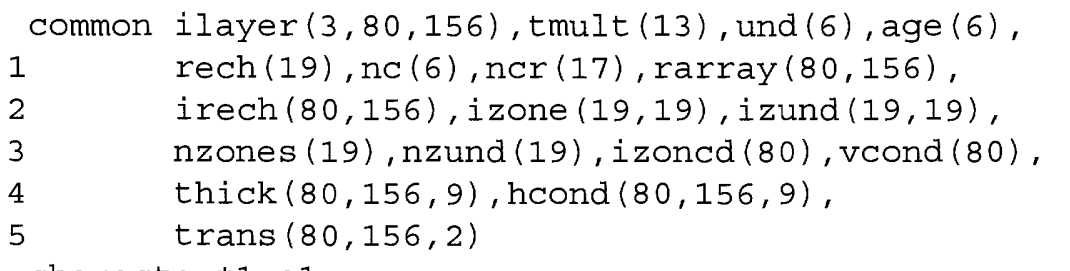

character*1 al

character*20 name (6), form, tname

OPEN (UNIT=15, FILE= ' UFLOWLAY2' , STATUS=' old' )

OPEN (UNIT $=16$, FILE = 'UFLOWLAY3' , STATUS=' old' )

OPEN (UNIT=17, FILE=' UFLOWLAY4', STATUS=' old')

OPEN (UNIT=8, FILE= ' undflw. 12' , STATUS= ' UNKNOWN' )

OPEN (unit =9, FILE=' params', STATUS='old' )

OPEN (unit $=10$, file=' rechrg.map' , status='old')

OPEN (unit $=11$, file $=$ ' rech001.18', status =' unknown' )

OPEN (unit $=12$, file= ' recharge' , status=' unknown' )

OPEN (unit $=13$, file='age 77', status=' unknown' )

OPEN (unit $=21$, file=' hcondl', status=' unknown')

OPEN (unit $=22$, file=' hcond2', status='unknown')

OPEN (unit $=23$, file=' hcond3', status=' unknown' )

OPEN (unit $=24$, file=' hcond4', status=' unknown')

OPEN (unit $=25$, file=' hcond5', status=' unknown')

OPEN (unit $=26$, file=' hcond6', status=' unknown')

OPEN (unit $=27$, file=' hcond7' , status=' unknown')

OPEN (unit $=28$, file=' trans8' , status=' unknown' )

OPEN (unit $=29$, file=' trans9' , status=' unknown')

OPEN (unit $=31$, file='vcon12', status=' unknown')

OPEN (unit $=32$, file='vcon23', status=' unknown')

OPEN (unit $=33$, file='vcon 34 ', status=' unknown' )

OPEN (unit $=34$, file='vcon45', status=' unknown')

OPEN (unit $=35$, file='vcon56', status=' unknown' )

OPEN (unit $=36$, file='vcon67', status='unknown' )

OPEN (unit $=37$, file='vcon78', status=' unknown')

OPEN (unit $=38$, file='vcon89', status=' unknown' )

OPEN (unit $=41$, file=' ZONE1 . array', status=' unknown' )

OPEN (unit $=42$, file=' ZONE2 . array', status=' unknown' )

OPEN (unit $=43$, file='ZONE3 . array', status=' unknown' )

OPEN (unit $=44$, file=' ZONE4 .array', status=' unknown' )

OPEN (unit $=45$, file=' ZONE5 . array', status=' unknown' )

OPEN (unit $=46$, file=' ZONE6. array', status=' unknown' )

OPEN (unit $=47$, file='ZONE7 . array', status=' unknown' )

OPEN (unit $=48$, file=' ZONE8 . array', status=' unknown' )

OPEN (unit $=49$, file=' ZONE9 . array', status=' unknown' )

OPEN (unit $=51$, file='thickl', status='unknown' )

OPEN (unit $=52$, file=' thick2', status=' unknown' )

OPEN (unit $=53$, file=' thick3', status=' unknown')

OPEN (unit $=54$, file='thick4', status=' unknown' )

OPEN (unit $=55$, file=' thick5', status=' unknown')

OPEN (unit $=56$, file=' thick6', status=' unknown' )

OPEN (unit $=57$, file=' thick7', status=' unknown')

OPEN (unit $=58$, file=' thick8', status='unknown') 
C

C

C

C
OPEN (unit=59, file='thick9', status=' unknown')

read in time recharge mulitpliers

tmult $0=1.0$

$\operatorname{read}(9, *)$ im 1, tmult 1

$\operatorname{read}(9, *)$ im2, tmult2

$\operatorname{read}(9, *)$ im3, tmult3

read $(9, *)$ im4, tmult 4

read $(9, *)$ im5, tmult 5

$\operatorname{read}(9, *)$ im6, tmult 6

if (im1.eq.0) tmult $1=0.5 *$ (tmult $0+t m u l t 2)$

if (im3.eq.0) tmult $3=0.5 *$ (tmult $2+t m u l t 4)$

if (im5.eq.0) tmult $5=0.5 *$ (tmult $4+$ tmult 6 )

tmult $(1)=(2 . * t m u l t 6+0 . * t m u l t 6) / 2$.

tmult $(2)=(1 . *$ tmult $6+1 . * t m u l t 5) / 2$.

tmult $(3)=(2 . *$ tmult5 $+0 . *$ tmult5 $) / 2$.

tmult $(4)=(1 . *$ tmult $5+1 . *$ tmult 4$) / 2$.

tmult $(5)=(2 . *$ tmult $4+0 . *$ tmult 4$) / 2$.

tmult $(6)=(1 . *$ tmult $4+1 . *$ tmult 3$) / 2$.

tmult $(7)=(2 . * t m u l t 3+0 . * t m u l t 3) / 2$.

tmult $(8)=(1 . *$ tmult $3+1 . *$ tmult 2$) / 2$.

tmult $(9)=(2 . * t m u l t 2+0 . * t m u l t 2) / 2$.

tmult $(10)=(1 . *$ tmult $2+1 . *$ tmult 1$) / 2$.

tmult $(11)=(2 . *$ tmult $1+0 . *$ tmult 1$) / 2$.

tmult $(12)=(1 . * t m u l t 1+1 . * t m u l t 0) / 2$.

tmult $(13)=(2 . *$ tmulto $+0 . *$ tmulto $) / 2$.

iwel $\mathrm{cb}=79$

read in the recharge code map

DO 5 IY $=1,156$

$\operatorname{READ}(10,4) \quad(\operatorname{IRECH}(\operatorname{IX}, I Y), I X=1,80)$

5 CONTINUE

4 FORMAT (40I2)

read $(9, *)$ nrechp

DO 9 irch=1, nrechp

$\operatorname{ncr}(\operatorname{irch})=0$

read $(9, *)$ nzones (irch), rech (irch)

$\operatorname{read}(9, *)$ (izone (iz, irch), iz=1, nzones (irch))

DO $8 I Y=1,156$

DO 7 IX $=1,80$

do 6 iz=1, nzones (irch)

IF (izone (iz, irch) .EQ.IRECH (IX, IY)) THEN $\operatorname{ncr}(\operatorname{irch})=\operatorname{ncr}(\operatorname{irch})+1$

ENDIF

CONTINUE

CONTINUE

CONTINUE

CONTINUE

$\operatorname{read}(9, *) \operatorname{rech}(18)$

$\operatorname{read}(9, *) \operatorname{rech}(19)$

read in recharge rates in (in acre-feet per year)

and convert to feet/day per square kilometer

do 10 irch $=1,19$ 


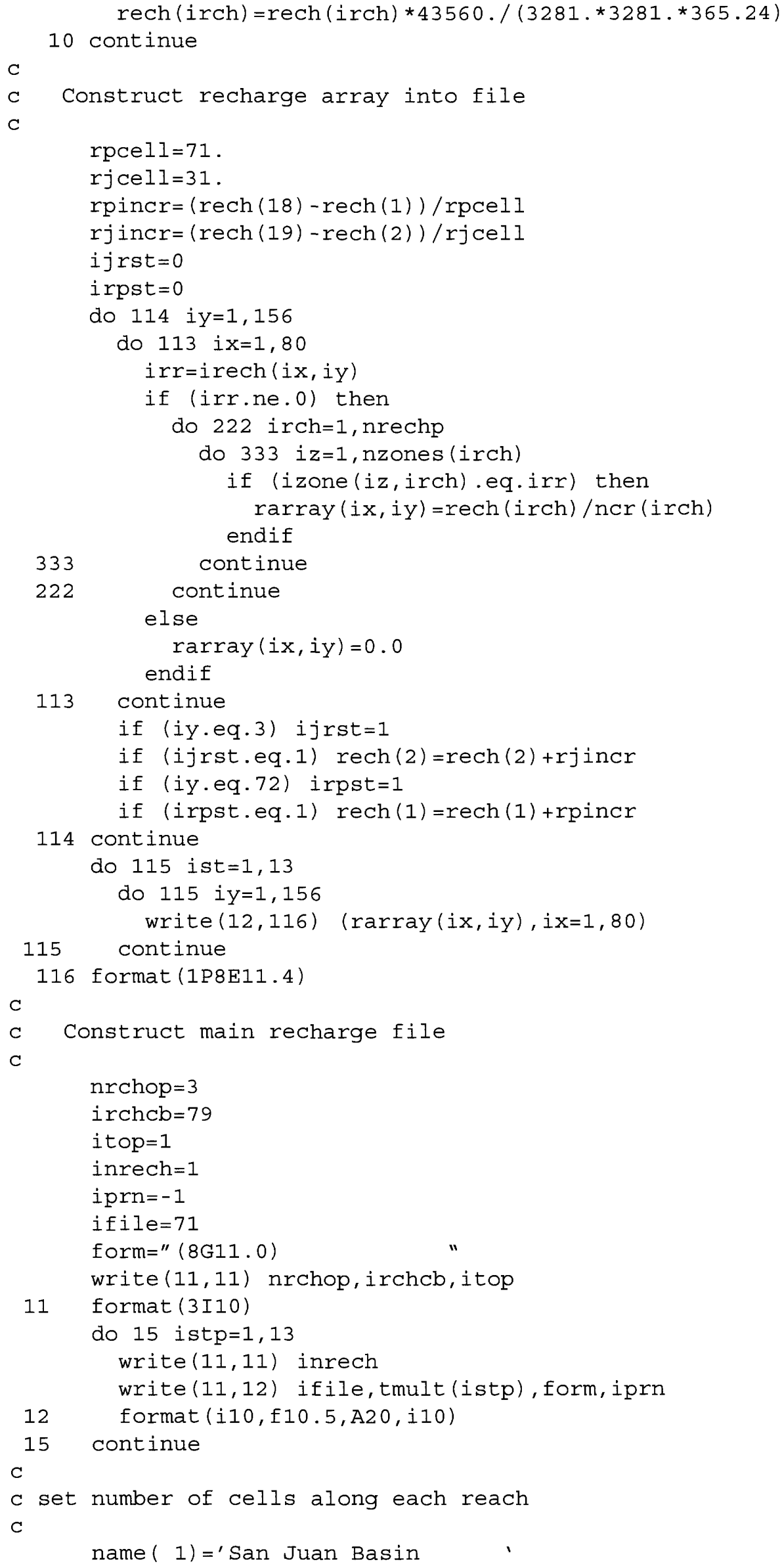


C

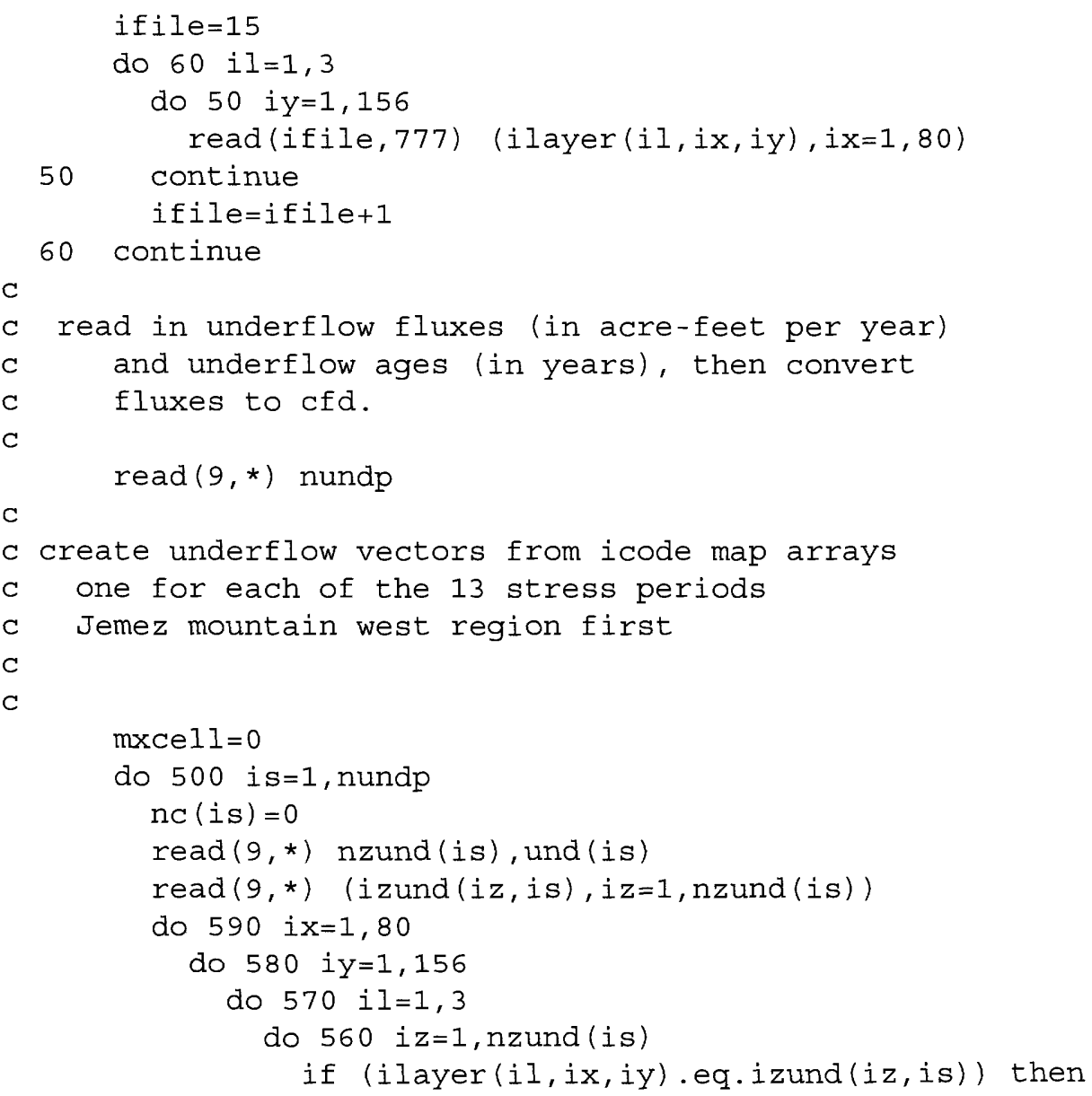




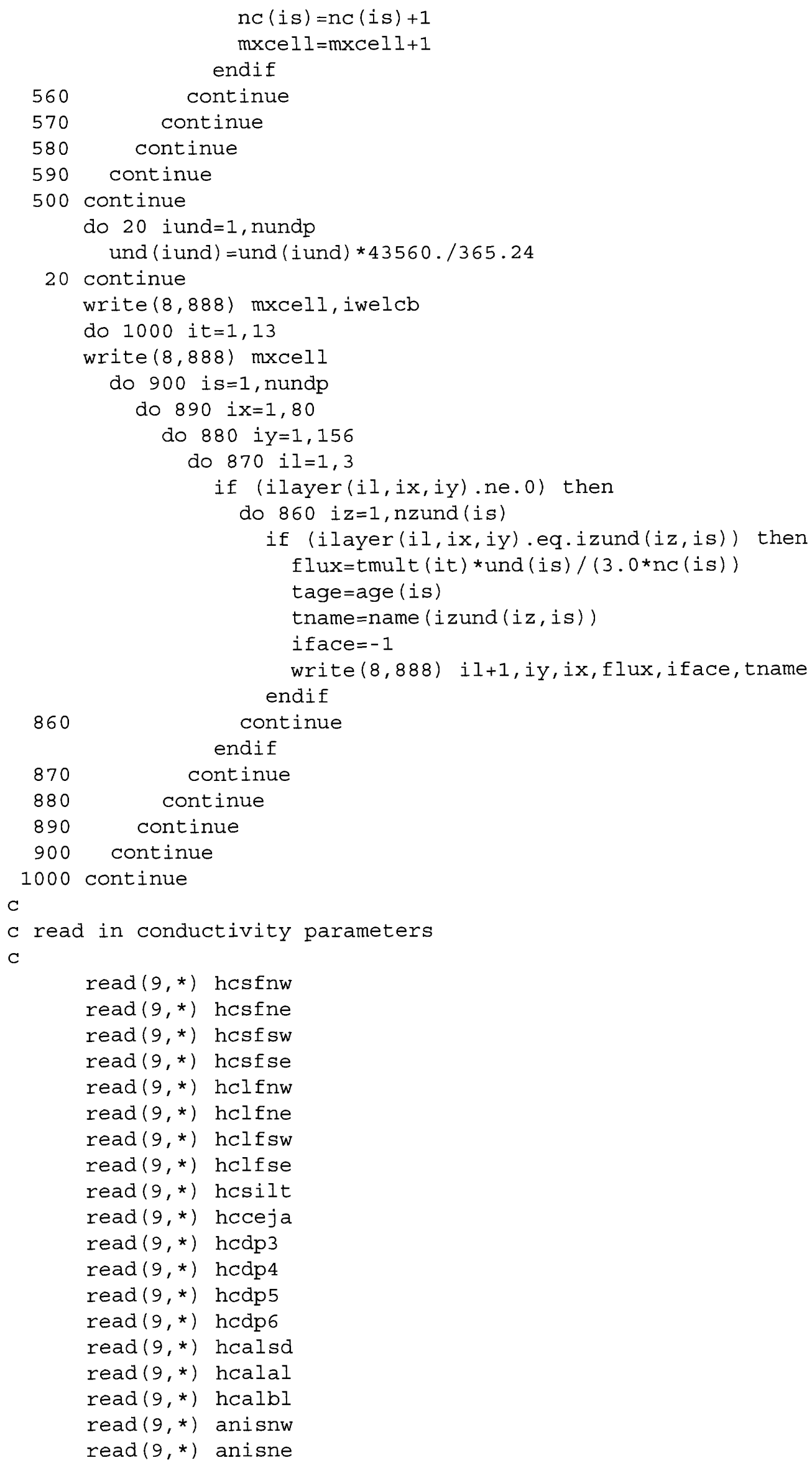




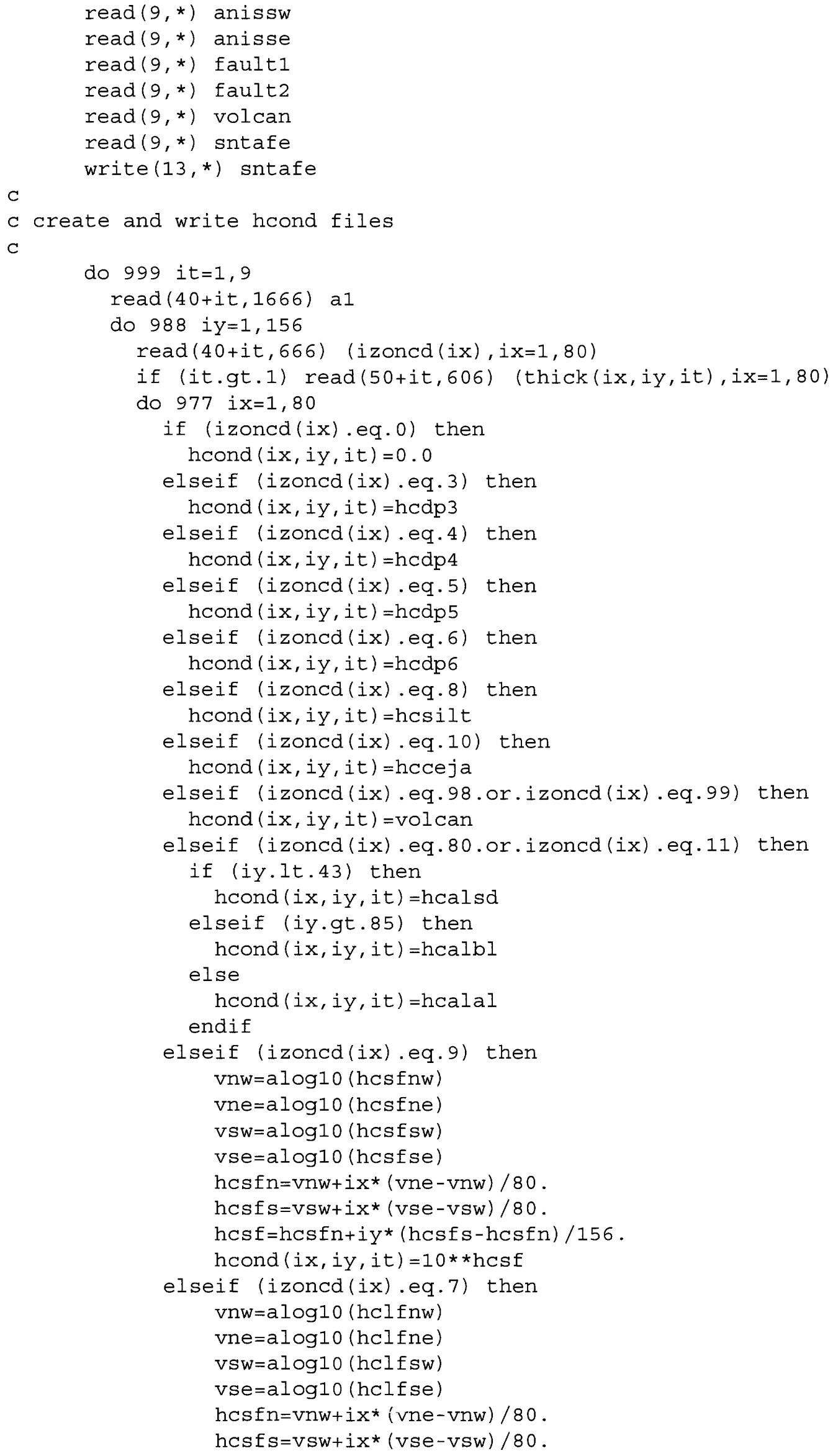




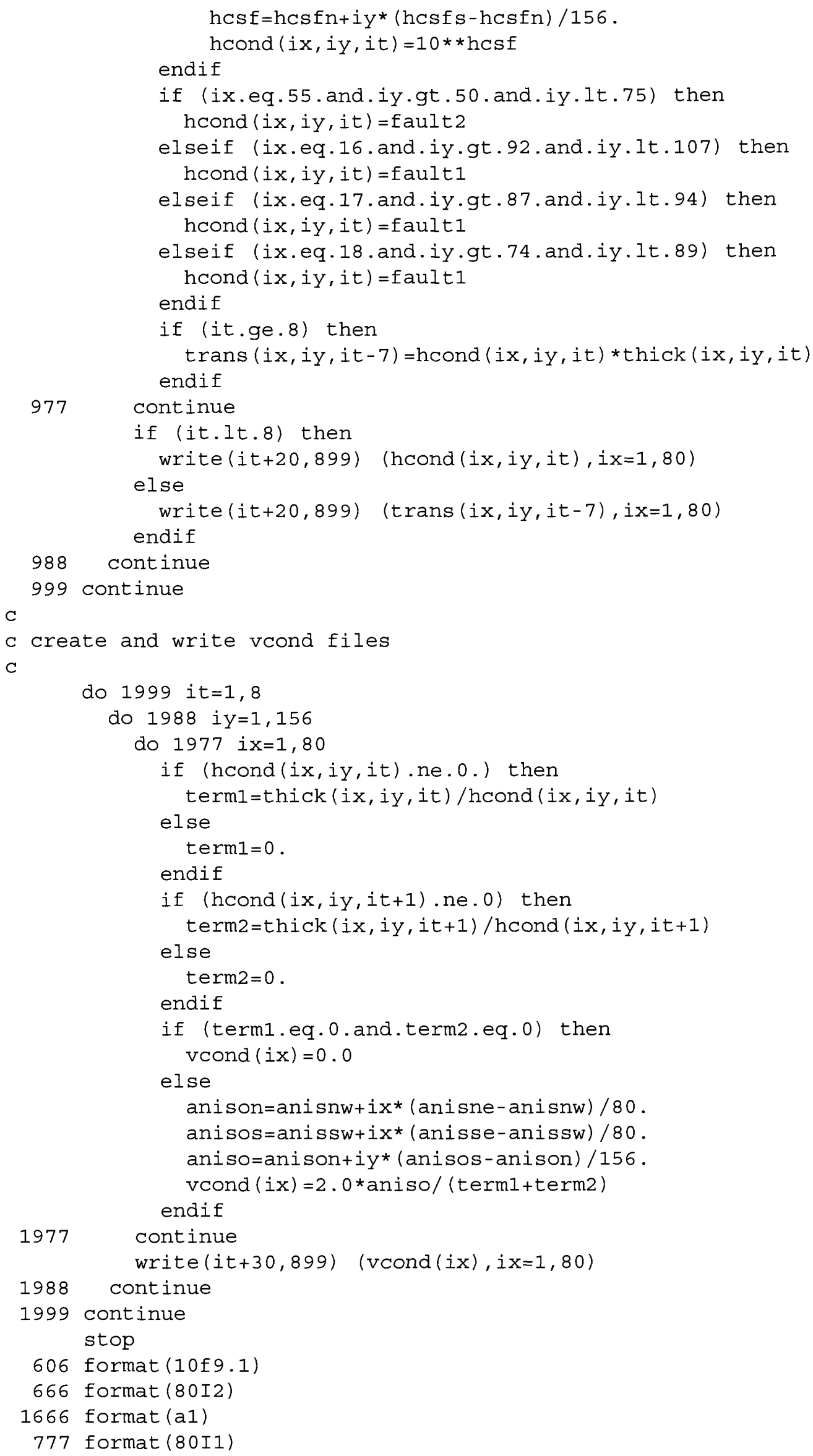


888 format $(3 \mathrm{I} 10, \mathrm{~F} 10.3, \mathrm{I} 10,5 \mathrm{X}, \mathrm{A} 20)$

899 format (1P1OE11.4)

end

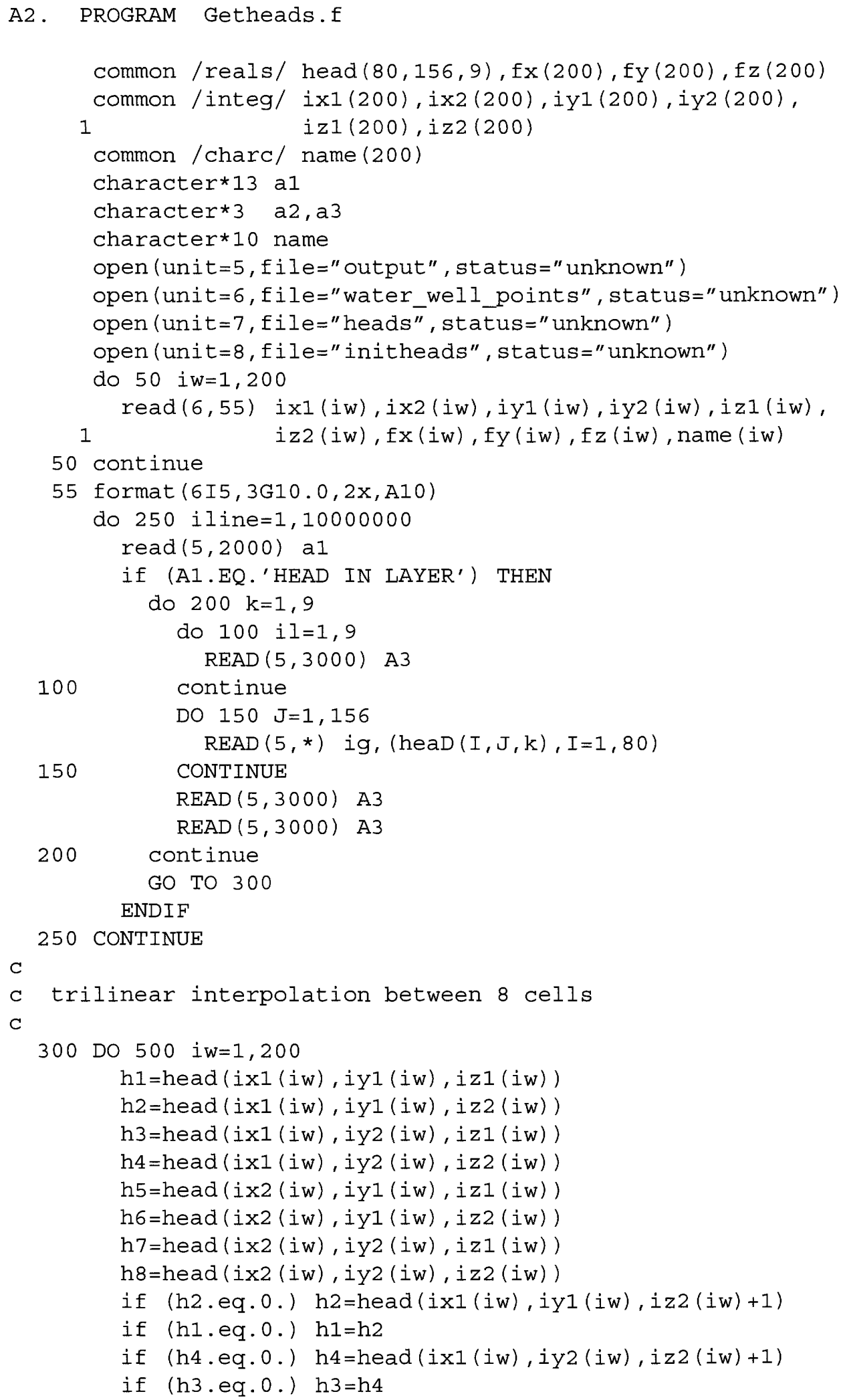




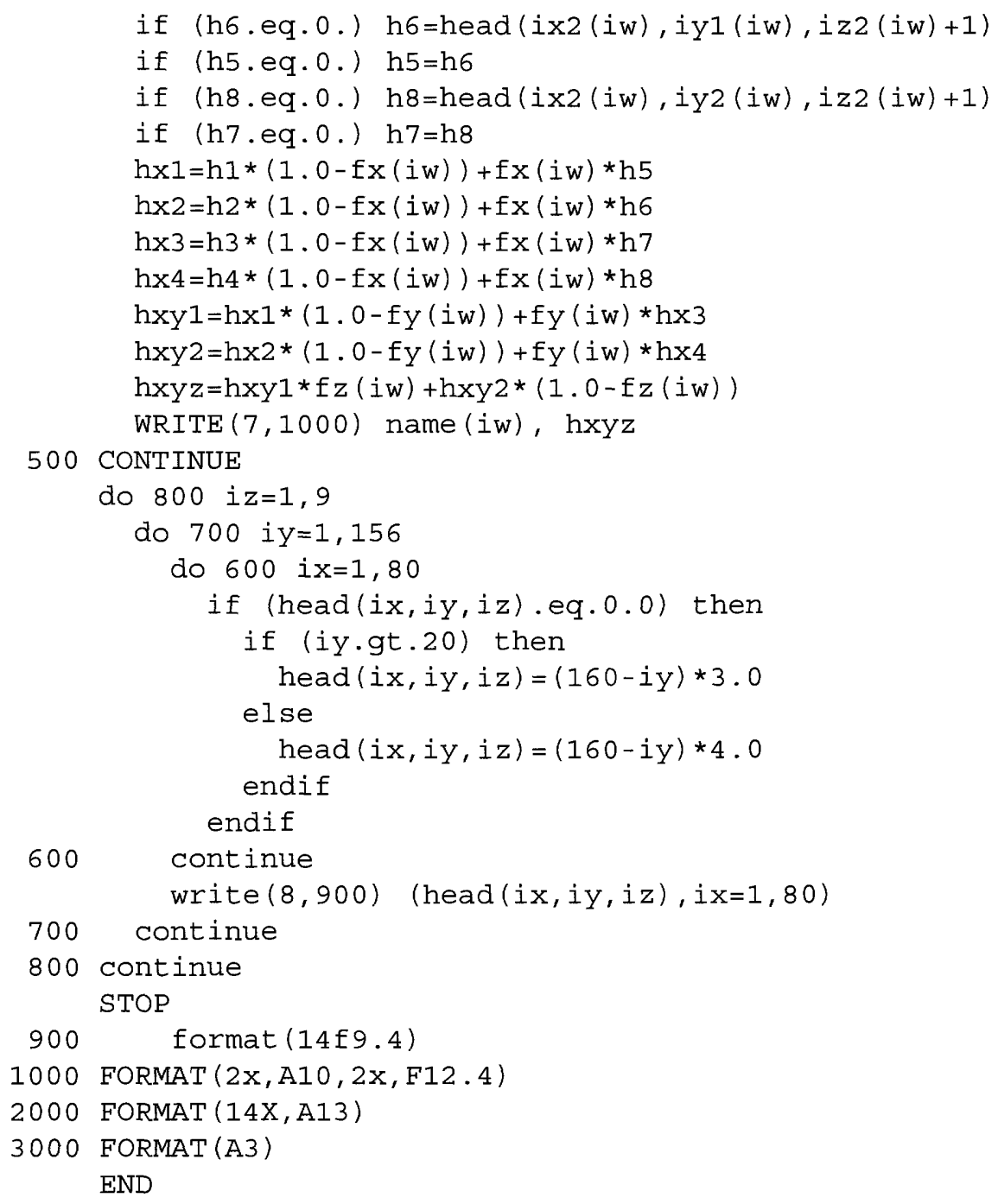

A3. PROGRAM POSt.f

character*25 wnamea, wnameb

open (unit $=5$, file=' endyears', status=' unknown')

open (unit $=6$, file=' c14ages', status=' unknown')

read $(5,200)$ iz, ixa, iya, il, time, c14a, it, $x, y$, wnamea

ikount $=1$

$\mathrm{c} 14 \mathrm{t}=\mathrm{C} 14 \mathrm{a}$

$10 \operatorname{read}(5,200)$ iz, ixb, iyb, il, time, $c 14 b$, it, $x, y$, wnameb

if (wnameb.eq.' source area delineation ') go to 50

if (wnamea.ne.wnameb) then

c14 =c14t $/$ ikount

write $(6,300)$ ixa, iya, c14, wnamea

ikount $=1$

$c 14 t=c 14 b$

else

ikount $=i$ kount +1

$c 14 t=c 14 t+c 14 b$

endif

$i x a=i x b$

iya $=i y b$ 
wnamea =wnamelo

go to 10

$50 \quad \mathrm{c} 14=\mathrm{c} 14 \mathrm{t} / \mathrm{ikount}$

write $(6,300)$ ixa, iya, c14, wnamea

C

$i z 1=0$

$i z 2=0$

i $z 3=0$

i $z 6=0$

i $z 7=0$

i $\mathrm{za}=0$

ip $1=0$

ip $2=0$

ip $3=0$

ip $4=0$

do 100 ip $=1,58000$

$\operatorname{read}(5,200$, end $=400)$ iz, ixb, iyb, il, time, c14b, it, $x, y$

$\mathrm{C}$

if $(y . g t .120$

.and.iz.eq.12) $i z 1=i z 1+1$

if (y.gt.80.and.y.1t.110.and.x.1t.45.and.iz.eq.12) iz2=iz2+1

if (y.gt.80.and.y.1t.110.and.x.gt.45.and.iz.eq.12) iz3=iz3+1

if (y.gt.50.and.y.1t.80 and.x.1t.40.and.iz.eq.12) iz6=iz6+1

if (y.gt.50.and.y.1t.80 and.x.gt.40.and.iz.eq.12) iz7=iz7+1

if (y.gt.20.and.y.1t.50 and.iz.eq.12) iza=iza+1

if (y.gt.60.and.y.1t.85 and.iz.eq. 5) $i p 1=i p 1+1$

if (y.gt.35.and.y.1t.60 and.x.1t.15.and.iz.eq. 5) ip2 $=i p 2+1$

if (y.gt.35.and.y.1t.60 and.x.gt.15.and.iz.eq. 5) ip3=ip3+1

if (y.gt.10.and.y.1t.35 .and.iz.eq. 5) ip4=ip4+1

continue

400 write $(6, *)$ iz2

C $\quad$ write $(6, *)$ iz2

write $(6, *)$ iz3

write $(6, *)$ iz6

write $(6, *)$ iz7

write $(6, *)$ iza

write $(6, *)$ ip1

write $(6, *)$ ip2

write $(6, *)$ ip3

write $(6, *)$ ip4

stop

200 format $(4 i 6, g 10.0, g 11.0, i 5,299.0, A 25)$

300 format (2I5, 1pe11.4,A25)

end 